
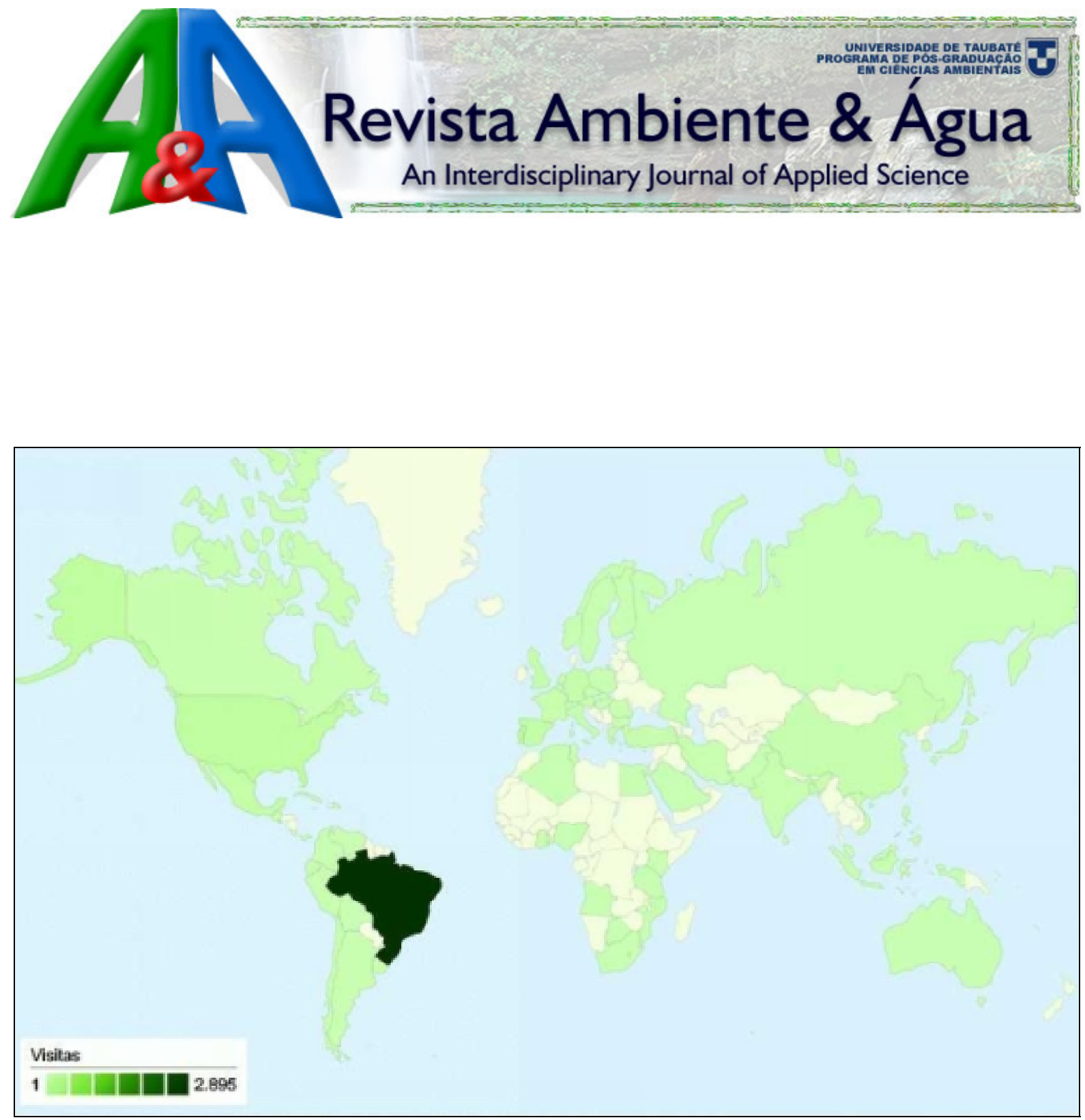

ISSN = 1980-993X (Online)

www.agro.unitau.br/ambi-agua

Edição 05 da Revista Ambiente \& Água - An Interdisciplinary Journal of Applied Science, Taubaté, v. 2, n. 3, p. 1-111, Dezembro 2007. (doi:10.4136/ambi-agua.v2.n3) 


\section{COMITÊ EDITORIAL}

\section{Editor}

Getulio Teixeira Batista

Instituto de Pesquisas Ambientais em Bacias Hidrográficas (IPABHi), Brasil

\section{Editores Associados}

Amaury Paulo de Souza

Universidade Federal de Viçosa (UFV), Brasil

Antonio Evaldo Klar

Universidade Estadual Paulista Júlio de Mesquita Filho, UNESP, Brasil

Dar Roberts

Universidade de Stanford; BA pela Universidade da Califórnia, EUA

Hans Raj Gheyi

Universidade Federal de Campina Grande (UFCG), Brasil

\section{Hélio Nóbile Diniz}

Instituto Geológico, Secretaria do Meio Ambiente do Estado de São Paulo (IG/SMA), Brasil

\section{João Vianei Soares}

Instituto Nacional de Pesquisas Espaciais (INPE), Brasil

Editor da Seção Editorial

Editora de Texto

Editora de Referência

Editor de Layout

Suporte Técnico
Luis A. Bartolucci

Florida International University (FIU), EUA

Marcelo dos Santos Targa

Universidade de Taubaté (UNITAU), Brasil

Nelson Wellausen Dias

Universidade de Taubaté (UNITAU), Brasil

Paul W. Mausel

Indiana State University (ISU), EUA

Paulo Renato Schneider

Universidade Federal de Santa Maria (UFSM), Brasil

Sebastião do Amaral Machado

Universidade Federal do Paraná (UFPR), Brasil

Silvio Jorge Coelho Simões

Universidade Estadual Paulista Júlio de Mesquita Filho (UNESP), Brasil

Yosio Edemir Shimabukuro

Instituto Nacional de Pesquisas Espaciais (INPE), Brasil

Nelson Wellausen Dias, PPGCA, UNITAU, Brasil

Maria de Jesus Ferreira Aires, GELP, UNITAU, Brasil

Liliane Castro, Biblioteca ECA/Civil, UNITAU, Brasil

Adam Querido Mazzei Ribeiro, LAGEO, UNITAU, Brasil

Marcio Vinicius Gagliotti, LAGEO, UNITAU, Brasil.

Ficha catalográfica elaborada pelo

SIBi - Sistema Integrado de Bibliotecas / UNITAU

Revista Ambiente \& Água - An Interdisciplinary Journal of Applied Science / Instituto de Pesquisas Ambientais em Bacias Hidrográficas. Taubaté. v. 2, n. 3 (2006) Taubaté: IPABHi, 2007.

Quadrimestral

ISSN 1980-993X

1. Ciências ambientais. 2. Recursos hídricos. I. Instituto de Pesquisas Ambientais em Bacias Hidrográficas. III. Título.

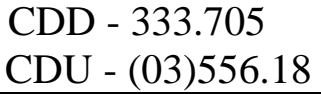




\section{Revisores Ad Hoc de Artigos do Ano 2007 \\ (Ambi-Agua volume 2, no . 1, 2 e 3, 2007)}

Revisores Ad Hoc

Instituição afiliada

Ana Teresa Lombardi

Antônio José Teixeira Guerra

Antônio Roberto Formaggio

Antônio Teixeira Matos

Caetano Chang Dorea

Camilo Daleles Rennó

Claudia de Albuquerque Linhares

Claudinei Fonseca Souza

Eduardo Antônio Gomes Marques

Enner Herenio Alcântara

Ernani Francisco da Rosa Filho

Flávio Jorge Ponzoni

Gerson Cardoso Silva Jr.

Gilberto Fisch

Hélio Nóbile Diniz

Henrique M. L. Chaves

Jaime Cabral

João Vianei Soares

Jorge Luiz Gavina Pereira

Jose A. Marengo

José Eduardo dos Santos

José Eloi Guimarães Campos

Luiz Fernando Nascimento

Marcelo dos Santos Targa

Márcio J. Estefano de Oliveira

Maria Claudia Barbosa

Maria de Jesus Robim
Universidade Federal de São Carlos

Universidade Federal do Rio de Janeiro

Instituto Nacional de Pesquisas Espaciais

DEA/Universidade Federal de Viçosa

Health Canada

Instituto Nacional de Pesquisas Espaciais

Instituto Nacional de Pesquisas Espaciais

Universidade de Taubaté

Universidade Federal de Viçosa

Instituto Nacional de Pesquisas Espaciais

Universidade Federal do Paraná

Instituto Nacional de Pesquisas Espaciais

Universidade Federal do Rio de Janeiro

Instituto de Aeronáutica e Espaço/ CTA e Universidade de Taubaté

Secret. Meio Ambiente do Est.de SP (IG/SMA)

Universidade de Brasília

Universidade Federal de Pernambuco

Instituto Nacional de Pesq. Espaciais (INPE)

Museu Paraense Emilio Göeldi

CPTEC-Estudos Climáticos/ (INPE)

Universidade Federal de São Carlos

Universidade de Brasília

Universidade de Taubaté/Universidade Estadual Paulista

Universidade de Taubaté

Universidade de Taubaté

COPPE-Universidade Federal do Rio de Janeiro

Instituto Florestal, Secretaria Meio Ambiente e Universidade de Taubaté 
Maria Lúcia Calijuri

Maria Victoria Ramos Ballester

Mario Valério Filho

Maurício Alves da Motta Sobrinho

Nelson Wellausen Dias

Paulo Cesar Sentelhas

Rauquírio André A. Marinho da Costa

Regina de Fátima Peralta Muniz Moreira

Sérgio Campos

Silvia Helena Govoni Brondi

Silvio Jorge Coelho Simões

Teresinha Guerra

Ubiratan Ferrucio Faccini

Valdemir Antonio Rodrigues

Vicente de Paulo Rodrigues Silva

Vicente Paulo Soares

Yoshiya Nakagawara Ferreira

Yosio Edemir Shimabukuro

Yuri Tavares Rocha
Universidade Federal de Viçosa

CENA/Universidade de São Paulo

Universidade do Vale do Paraíba

Universidade Federal de Pernambuco

Universidade de Taubaté

ESALQ - Universidade de São Paulo

Universidade Federal do Pará

Universidade Federal de Santa Catarina

Universidade Estadual Paulista

Embrapa Pecuária Sudeste

Universidade Estadual Paulista

Universidade Federal do Rio Grande do Sul

Universidade do Vale do Rio dos Sinos

Universidade Estadual de São Paulo

Universidade Federal de Campina Grande

Universidade Federal de Viçosa

Universidade Estadual de Londrina

Instituto Nacional de Pesquisas Espaciais

Universidade de São Paulo

Obs.: 1) A lista inclui revisores que avaliaram mais de um artigo.

2) A lista inclui revisores de artigos que foram rejeitados 


\section{Lista de Avaliadores Ad Hoc Registrados da Revista Ambiente \& Água (até a presente edição)}

Adão Benvindo Luz

Adauto de Souza Ribeiro

Adilson Pinheiro

Adonis Moreira

Adriana Vasconcellos

Adriano Wagner Ballarin

Alaide Aparecida Fonseca-Gessner

Alcindo dos Santos

Alex Vladimir Krusche

Alexandre de Avila Leripio

Alexandre Gonçalves Evsukoff

Alexandre Guirland Nowosad

Alexandre Magno Sebbenn

Alexandre Marco da Silva

Alfredo Pereira

Ana Teresa Lombardi

Anderson Orestes Cavalcante Lobato

Andréa Bogatti Guimarães Tomazela

Antonio Caetano Vaz Caltabiano

Antonio Carlos Vitte

Antonio César Ortega

Antonio Jose Teixeira Guerra

Antonio Roberto Formaggio

Antonio Teixeira Matos

Aparecido Osdimir Bertolin

Arimatéa Carvalho Ximenes

Aureo Eduardo Magalhães Ribeiro

Bernardo Rudorff

Brani Rozemberg

Caetano Chang Dorea

Camilo daleles Rennó
Centro de Tecnologia Mineral

Universidade Federal de Sergipe

Universidade Regional de Blumenau

Embrapa Pecuária Sudeste

Universidade de Taubaté

Universidade Estadual Paulista - Faculdade de

Ciências Agronômicas

Universidade Federal de São Carlos

Universidade Federal de São Carlos

Centro de Energia Nuclear Na Agricultura -

Universidade de São Paulo

Universidade do Vale do Itajaí

COPPE - Universidade Federal do R. de Janeiro

Instituto Nacional de Pesq. Espaciais (INPE)

Instituto Florestal de São Paulo

Universidade Estadual Paulista

Instituto Nacional de Pesq. Espaciais (INPE)

Universidade Federal de São Carlos

Universidade Federal de Pelotas

Universidade Estadual Paulista

International Clivar Project Office

Universidade de Campinas

Universidade Federal de Uberlândia

Universidade Federal do Rio de Janeiro

Instituto Nacional de Pesquisas Espaciais

Universidade Federal de Viçosa

Universidade Federal do Tocantins

Instituto Nacional de Pesquisas Espaciais

Universidade Federal de Lavras

Instituto Nacional de Pesquisas Espaciais

Fundação Oswaldo Cruz

University of Glasgow

Instituto Nacional de Pesquisas Espaciais 
Carlos Andre Bulhões Mendes

Carlos Edwar Freitas

Carlos Ernesto Schaefer

Carlos Moure Cicero

Carlos Rogério Mello

Carmen Lidia Amorim Pires Zottarelli

Carmen Lucia Paiva Silveira

Catarina da Silva Pedrozo

Cecília Volkmer Ribeiro

Celso Augusto Guimarães Santos

César Ulisses Vieira Veríssimo

Chigueru Tiba

Cilene Gomes

Claudia Albuquerque Linhares

Claudinei Fonseca Souza

Claudio José Von Zuben

Claudio Luis Frankenberg

Corina da Costa Freitas

Cyro Barros Rezende-Filho

Daniel Alves Aguiar

Denilson Teixeira

Dirceu Luis Herdies

Durval Dourado

Edson Rodrigues

Eduardo Antonio Gomes Marques

Eduardo Marone

Eduardo Pereira Cabral Gomes

Eduardo Rodrigues Viana de Lima

Eduardo von Sperling

Elmo Rodrigues da Silva

Emilia de Rodat Fernandes Moreira

Enio F. F. Silva

Enner Herenio Alcântara

Ernani Francisco da Rosa filho
IPH - Universidade Fed. do Rio Grande do Sul

Universidade Federal do Amazonas

Universidade Federal de Viçosa

Universidade de Taubaté

Universidade Federal de Lavras

Instituto de Botânica de São Paulo

Centro Universitário Plínio Leite

Universidade Federal do Rio Grande do Sul

Fundação Zoobotânica do RGS

Universidade Federal da Paraíba

Universidade Federal do Ceará

Universidade Federal de Pernambuco

Universidade Federal do Rio Grande do Norte

Instituto Nacional de Pesquisas Espaciais

Universidade de Taubaté

Universidade Estadual Paulista

Pontifícia Universidade do Rio Grande do Sul

Instituto Nacional de Pesquisas Espaciais

Universidade de Taubaté

Instituto Nacional de Pesquisas Espaciais

Centro Universitário de Araraquara

Instituto Nacional de Pesquisas Espaciais

Universidade de Sao Paulo, Esalq

Universidade de Taubaté

Universidade Federal de Viçosa

Universidade Federal do Paraná

Instituto de Botânica

Universidade Federal da Paraíba

Universidade Federal de Minas Gerais

Universidade do Estado do Rio de Janeiro

Universidade Federal da Paraíba

Universidade Federal Rural de Pernambuco

Instituto Nacional de Pesquisas Espaciais

Universidade Federal do Paraná 
Eugenio Avila Pedrozo

Evlyn Márcia Novo

Fábio Marcelo Breunig

Fabricio Sanguinetti Cruz de Oliveira

Flávia Cristina Sossae

Flavio Cesar Borba Mascarenhas

Flávio Jorge Ponzoni

Flavio Jose Malta

Francisco de Sousa Ramos

Francisco Gonçalves da Silva

Francisco Roberto Azevedo

Fulvio Rodriguez Simão

Georgina Bond Buckup

Gerson Cardoso Silva Jr.

Getulio Rincon

Getulio Teixeira Batista

Gilberto Fisch

Gilson Barbosa Athayde Júnior

Glicério Trichês

Gustavo Ferreira Simões

Helena Carvalho Lorenzo

Helio Grassi Filho

Hélio Nóbile Diniz

Herickson Akihito Sudo Lutif

Hermann Johann Heinrich Kux

Herminia Yohko Kanamura

Homero Giorge Cerqueira

Horst Frischkorn

Hugo Moreira Soares

Humberto Calloni

Ijar Milagre da Fonseca

Iraê Amaral Guerrini

Itamar Alves Martins
Universidade Federal do Rio Grande do Sul

Instituto Nacional de Pesquisas Espaciais

Instituto Nacional de Pesquisas Espaciais

Instituto Oceanográfico da Universidade de São Paulo

Centro Universitário de Araraquara

Universidade Federal do Rio de Janeiro

Instituto Nacional de Pesquisas Espaciais

Universidade de Taubaté

Universidade Federal de Pernambuco

Universidade Federal da Paraíba

Universidade Federal do Ceará

Empresa de Pesquisa Agropecuária de Minas

Gerais

Universidade Federal do Rio Grande do Sul

Universidade Federal do Rio de Janeiro

Universidade Estadual Paulista

Universidade de Taubaté

CSA/CTA e Universidade de Taubaté

Universidade Federal da Paraíba

Universidade Federal de Santa Catarina

Universidade Federal de Minas Gerais

Centro Universitário de Araraquara

Universidade Estadual Paulista

Instituto Geológico do Estado de São Paulo

Universidad Carlos III de Madrid

Instituto Nacional de Pesquisas Espaciais

Universidade de Taubaté

Policia Militar/ Universidade Cruzeiro do Sul

Universidade Federal do Ceará

Universidade Federal de Santa Catarina

Fundação Universidade Federal do Rio Grande

Instituto Nacional de Pesquisas Espaciais

Universidade Estadual Paulista

Universidade de Taubaté 
Jacob Binsztok

Jaime Cabral

Jairo José de Oliveira Andrade

João Carlos Pinheiro Beck

João Graciano Mendonça Filho

Joao Luiz Lani

João Vianei Soares

Joel Avruch Goldenfum

Jorge Rubio

Jorge Xavier da Silva

José Alberto Quintanilha

José Antonio Perrella Balestieri

José Carlos Becceneri

José Carlos de Araújo

José Carlos Mierzwa

José Dias Corrêa Junior

José Eduardo dos Santos

José Eloi Guimarães Campos

José Euclides Stipp Paterniani

José Geraldo Querido

José Marques da Costa

José Renato Boucas Farias

Juliana Cristina Barreiro

Leonardo Santos Collier

Leonor Almeida Souza-Soares

Lia Osorio Machado

Lidriana de Souza Pinheiro

Loreley Gomes Garcia

Lucia Maria Sa Antunes Costa

Luciano Farinha Watzlawick

Luis Alberto Basso

Luis Antônio Serrão Contim

Luis Eduardo Aragon
Universidade Federal Fluminense

Universidade Federal de Pernambuco

Pontifícia Universidade do Rio Grande do Sul

Pontifícia Universidade do Rio Grande do Sul

Amento de Geologia, Instituto de Geociências,

Universidade Federal do Rio De Janeiro

Universidade Federal de Viçosa

Insituto Nacional de Pesquisas Espaciais

Universidade Federal do Rio Grande do Sul

Universidade Federal do Rio Grande do Sul

Universidade Federal do Rio de Janeiro

Escola Politécnica da Univ. de São Paulo

Universidade Estadual Paulista Julio de

Mesquita Filho

Instituto Nacional de Pesquisas Espaciais

Universidade Federal do Ceará

Universidade de São Paulo

Universidade Federal de Minas Gerais

Universidade Federal de São Carlos

Universidade de Brasília

Universidade de Campinas

Universidade de Taubaté

Universidade de Taubaté

Embrapa Soja

Universidade Federal de São Carlos

Universidade Federal do Tocantins

Fundação Universidade Federal do Rio Grande

Universidade Federal do Rio de Janeiro

Universidade Estadual do Ceará

Universidade Federal da Paraíba

Universidade Federal do Rio de Janeiro

Universidade Estadual do Centro-Oeste

Universidade Federal do Rio Grande do Sul

Centro Universitário Nilton Lins

Universidade Federal do Pará 
Luís Fernando Stone

Luiz Fernando Coutinho Oliveira

Luiz Fernando Nascimento

Magda Adelaide Lombardo

Manoel Alonso Gan

Mara Regina Rizzatti

Marçal José Rodrigues Pires

Marcelo dos Santos Targa

Marcelo Friederichs Landim Souza

Marcelo Santos Chaves

Márcio Balbino Cavalcante

Márcio J. Estefano de Oliveira

Márcio J. Estefano de Oliveira

Marco Antonio Igarashi

Marcos Adami

Marcos Gervasio Pereira

Marcos Rivail Silva

Marcos Vinícius Folegatti

Marcus Cesar Avezum Castro

Maria Anita Mendes

Maria Claudia Barbosa

Maria Cristina Crispim

Maria Cristina Vidotte Blanco Tarrega

Maria do Carmo Vieira

Maria Dolores Alves Cocco

Maria Elaine de Oliveira

Maria Helena Arruda Leme

Maria Hermínia Ferreira Tavares

Maria Inês Salgueiro Lima

Maria Isabel Queiroz

Maria Jesus Robim

Maria Lúcia Ribeiro

Mariko Ueno
Embrapa Arroz e Feijão

Universidade Federal de Lavras/Universidade Federal de Goiás

Universidade de Estadual Paulista/Universidade de Taubaté

Universidade Estadual Paulista

Instituto Nacional de Pesquisas Espaciais

Pontifícia Universidade do Rio Grande do Sul

Pontifícia Universidade do Rio Grande do Sul

Universidade de Taubaté

Universidade Estadual de Santa Cruz

Universidade Federal da Paraíba

Universidade Estadual da Paraíba

Universidade de Taubaté

Universidade de Taubaté

Universidade Federal do Ceará

Instituto Nacional de Pesquisas Espaciais

Universidade Federal do Rio de Janeiro

Universidade Regional de Blumenau

Universidade de São Paulo

Universidade Estadual Paulista

Universidade de São Paulo

Universidade Federal do Rio de Janeiro

Universidade Federal da Paraíba

Universidade Federal de Goiás

Universidade Federal da Grande dourados

Universidade de Taubaté

Universidade Federal Fluminense

Universidade Presbiteriana Mackenzie

Universidade Estadual do Oeste do Paraná

Universidade Federal de São Carlos

Fundação Universidade Federal do Rio Grande

Instituto Florestal/SMA-SP

Centro Universitário de

Araraquara/Universidade Estadual Paulista

Universidade de Taubaté 
Mário Augusto Jardim

Marisete Dantas Aquino

Marta Bustos Romero

Mauricio Alves Alves Moreira

Maurício Alves da Motta Sobrinho

Milton Kampel

Neida Patias Volpi

Nelson Wellausen Dias

Nestor Aldo Campana

Néstor Antonio Heredia Zárate

Ney Augusto Nascimento

Orivaldo Brunini

Osmar Alves Lameira

Pablo Santana Santos

Patrick Thierry Seyler

Paula Benevides de Morais

Paulo Cesar Sentelhas

Paulo Fortes Neto

Paulo Roberto Paulo Roberto

Paulo Roberto Meneses

Paulo Sergio Graziano Magalhaes

Pedro R. Jacobi

Pedro Teixaira Lacava

Rauquírio André Albuquerque Marinho da Costa

Regina Peralta Moreira

Regis Alexandre Lahm

Reinaldo José da Silva

Rejane Magalhães de Mendonça Pimentel

Renato Fontes Guimarães

Renato Mello Prado

Ricardo Santos

Richarde Marques Silva

Roberto de Oliveira
Museu Paraense Emilio Goeldi

Universidade Federal do Ceará

Universidade de Brasília

Instituto Nacional de Pesquisas Espaciais

Universidade Federal de Pernambuco

Instituto Nacional de Pesquisas Espaciais

Universidade Federal do Paraná

Universidade de Taubaté

Universidade de Brasília

Universidade Federal da Grande Dourados

Universidade Federal do Paraná

Instituto Agronômico de Campinas

Embrapa Amazônia Oriental

Instituto Nacional de Pesquisas Espaciais

Universidade de Brasília

Universidade Federal do Tocantins

Universidade de São Paulo

Universidade de Taubaté

Universidade Federal de Viçosa

Universidade de Brasília

Universidade de Campinas

Universidade de São Paulo

Instituto Tecnológico de Aeronáutica

Universidade Federal do Pará

Universidade Federal de Santa Catarina

Pontifícia Universidade Católica do Rio Grande do Sul

Universidade Estadual Paulista

Universidade Federal Rural de Pernambuco

Universidade de Brasília

Universidade Estadual Paulista Campus

Jaboticabal

Universidade Federal de Viçosa

Universidade Federal da Paraíba

Universidade Federal de Santa Catarina 
Roberto José Carvalho

Roberto Luiz Carmo

Rogério Nora Lima

Ronaldo Borges Barthem

Ronaldo Viana Soares

Rosa Maria Formiga Johnsson

Rouverson Pereira da Silva

Sandro Froehner

Serafim Daniel Ballestero

Sérgio Campos

Shiguenoli Miyamoto

Silvia Helena Govoni Brondi

Simey Thury Vieira Fisch

Simone Pinheiro Pereira

Solon Jonas Longhi

Sonia Cristina J. G. de Andrade Perez

Stelio Maia Menezes

Susana Inés Segura Muñoz

Teresinha Guerra

Thereza Christina Almeida Rosso

Ubirajara Aluizio Mattos

Ubiratan Ferrucio Faccini

Ulisses Thadeu Vieira Guedes

Valdemar Luiz Tornisielo

Vicente de Paulo Rodrigues Silva

Vicente Paulo Soares

Walter de Paula Lima

Washington Franca Rocha

Yanko Marcius de Alencar Xavier

Yoshiya Nakagawara Ferreira

Yosio Edemir Shimabukuro

Yuri Tavares Rocha
Pontifícia Universidade Católica do Rio de Janeiro

Universidade de Campinas

Centro Federal de Educação Tecnológica do Piauí

Museu Paraense Emílio Goeldi

Universidade Federal do Paraná

Universidade do Estado do Rio de Janeiro

Universidade Estadual Paulista/Jaboticabal

Universidade Federal do Paraná

Universidade de Taubaté

Universidade Estadual Paulista

Universidade Estadual de Campinas

Embrapa Pecuária Sudeste

Universidade de Taubaté

Universidade Federal do Pará

Universidade Federal de Santa Maria

Universidade Federal de São Carlos

Universidade Federal de Lavras

Universidade de São Paulo

Universidade Federal do Rio Grande do Sul

Universidade do Estado do Rio de Janeiro

Universidade do Estado do Rio de Janeiro

Universidade do Vale do Rio dos Sinos

Instituto Nacional de Pesquisas Espaciais

Universidade de São Paulo

Universidade Federal de Campina Grande

Universidade Federal de Viçosa

Universidade de São Paulo

Universidade Estadual de Feira de Santana

Universidade Federal do Rio Grande de Norte

Universidade Estadual de Londrina

Instituto Nacional de Pesquisas Espaciais

Universidade de São Paulo 


\section{ÍNDICE}

\section{CAPA}

Países de onde acessaram com maior freqüência a Ambi-Água no período de 2,5 meses (01 de outubro a 15 de dezembro de 2007).

Fonte: BATISTA, G. T. Abrangência geográfica de periódicos científicos. Ambi-Agua, Taubaté, v. 2, n. 3, p. 12-18, 2007. (doi:10.4136/ambi-agua.29)

\section{EDITORIAL}

Abrangência geográfica de periódicos científicos (doi:10.4136/ambi-agua.29)

Getulio Teixeira Batista

\section{ARTIGOS}

Soil loss prediction in Guaraíra river experimental basin, Pernambuco, Brazil based on two erosion simulation models (doi:10.4136/ambi-agua.30)

Richarde Marques da Silva; Celso A. G. Santos; Leonardo Pereira e Silva;

Jorge Flávio C. B. da Costa Silva

Ecotoxicological evaluation of leachate from the Limeira sanitary landfill with a view to indentifying acute toxicity (doi:10.4136/ambi-agua.31)

Núbia Natália de Brito-Pelegrini; Ronaldo Teixeira Pelegrini;

José Euclides Stipp Paterniani

Avaliação da interação de Zinco, Alumínio, Cobre e Manganês em Chromobacterium violaceum (doi:10.4136/ambi-agua.32)

Tânia Cristina Sumita; Rogério Santos Pereira; Messias Borges Silva; Luis Carlos Laureano da Rosa; Mariko Ueno

Fármacos, ETEs e corpos hídricos (doi:10.4136/ambi-agua.33)

Ricardo Wagner Reis Filho; Juliana Cristina Barreiro; Eny Maria Vieira

Quezia Bezerra Cass

Estudo químico ambiental do rio Murucupi - Barcarena, PA, Brasil, área impactada pela produção de alumínio (doi:10.4136/ambi-agua.34)

Simone de Fátima Pereira; Maurício Araújo de Lima; K'Ellen Heloizy Freitas; Cleide Samara Mescouto; Augusto Fonseca Saraiva

Avaliação da transformação da paisagem na bacia do ribeirão Vidoca, São José dos Campos, SP, Brasil (doi:10.4136/ambi-agua.35)

André Stempniak; Getulio Teixeira Batista; Ademir Fernando Morelli

Controle qualitativo e quantitativo do escoamento pluvial urbano com bacias de detenção (doi:10.4136/ambi-agua.36)

Néstor Aldo Campana; Ricardo Silveira Bernardes; Jolival Antonio da Silva Jr. 


\begin{tabular}{|c|} 
ISSN = 1980-993X - doi:10.4136/1980-993X \\
www.agro.unitau.br/ambi-agua \\
E-mail: ambi-agua@agro.unitau.br \\
Tel.: (12) 3625-4116
\end{tabular}

\title{
Geographical impact of scientific journals \\ (doi:10.4136/ambi-agua.29)
}

\author{
Getulio Teixeira Batista \\ Professor at the Master Degree Program in Environmental Sciences of the University of Taubaté. \\ Estrada Municipal Dr. José Luiz Cembranelli, 5.000; Bairro Itaim; 12.081-010 - Taubaté, SP \\ E-mail: ambi-agua@agro.unitau.br
}

\begin{abstract}
One important quality measure of a scientific journal is its scope, not just the scientific coverage, but also the geographical impact. In fact, the primary classification system, used to evaluate and grade scientific journals' quality in Brazil, known as Qualis CAPES, when classifying a journal attributes a quality grade A, B or C, and also adds an indication of the journal's geographical impact: Local, National or International. This classification system is used by several other institutions, especially by research funding agencies, for instance, CNPq, whose thematic committees use Qualis CAPES classification to quantify the researchers' and Research Groups' productivity. This article discusses several possibilities for geographical impact evaluation and presents the mechanism used by Ambiente e Água - An Interdisciplinary Journal of Applied Science (Ambi-Água) to monitor the extent of its spatial impact.
\end{abstract}

Keywords: Ambi-Agua; Qualis CAPES; Google Analytics; academic journals indexing; Environment and Water.

\section{INTRODUCTION}

Until recently the evaluation of the geographical impact of a scientific journal was limited to the analysis of the authors' or experimental sites' origin and to citation indices for instance, the "Science Citation Index (SCI®)" or the Journal Citation Reports (JCR®), maintained since 1975 by Thomson Scientific (2007).

Dewitt et al. (1980), analyzing several systems recognized the importance of the citations indices but, advised that it should be used with great caution in order to ascertain the quality of an article or a scientific journal, especially, due to self citations or many authors' articles. Buchanan (2007) called attention to another deficiency of those citations indices when the editorial procedure of a journal doesn't identify clearly when a citation begins and when it finishes. Gupta et al. (2005) discussed mathematically how citations develop with time in the academia community and mentioned that most publications are not referenced after five years, except, few relevant articles. Szklo (2006) indicated the need for quality evaluation of articles after they have been published and concluded that citation indices should not be used and mentioned several flaws of those indices based on Walter et al. (2003) study. These authors indicated that the "Impact Factor" (IF), defined as the number of citations divided by the number of articles published in the two previous years is conceptually and technically flawed due to the following reasons:

- $\quad$ "the quality of published material cannot be constrained by time - the two-year period set by the ISI for citations is arbitrary; 
- the number of journals in the ISI's database is a minute proportion of those published;

- $\quad$ reviews are cited more frequently than original research, thus favouring journals that opt for these articles as part of a publishing strategy;

- $\quad$ the IF does not take into account self-citations, which amount to a third of all citations;

- $\quad$ errors are common in reference lists (occurring in up to a quarter of references), inevitably affecting IF accuracy; and

- $\quad$ the assumption of a positive link between citations and quality is ill-founded, in that we cite articles for diverse reasons, including to refer to research judged suspect or poor."

Walter et al. (2003), in addition, related the following criteria as quality indicators:

- $\quad$ "adds consequentially to the field through original, innovative research findings;

- $\quad$ expands or challenges current knowledge;

- $\quad$ opens additional areas for new research activity;

- $\quad$ opens a pathway to advance knowledge;

- $\quad$ integrates discoveries obtained by different approaches and/ or disciplines through creative synthesis, thus bringing new insights to bear on original research; and

- $\quad$ reflects critically on research findings to guide the direction of further research.”

Of course those recommendations by Walter et al. (2003) for post publication analysis of an article can be included in the editorial procedure before the publication depending on the editorial policy of the journal.

\section{Brazilian system for quality evaluation of scientific journals - the Qualis CAPES system}

The Brazilian government agency, CAPES, is responsible for the classification of journals associated with accredited graduate degree programs. The journals are classified according to their circulation as Local, National, or International and to their quality as Ahigh, B-average, and C-low, by several evaluation committees within CAPES sub-areas. CAPES uses the Qualis system to evaluate the Graduate Schools National System. The system is based on information annually supplied by the graduate programs: the so-called "Coleta de Dados" package. This is a computerized system that collects information about registered graduate degree programs in the National System of Masters, Doctorate and Professional Master's Degrees.

The classification is implemented by the specific Evaluation Area using an application called WebQualis. A journal can have, in different areas, different classifications. Areas have their own criteria, previously defined after following guidelines established by the CAPES Technical Scientific Council. Annually the system is updated with new journals. For a journal to be inserted in the Qualis list it must have been previously listed in the Annual Report sent to CAPES ("Coleta de Dados"), with an indication that professors, students or researchers have published scientific articles in that journal. Later on, that journal undergoes a standard check to confirm the validity of the ISSN code and of the journal's title. Additionally, it has to be indicated by the Evaluation Area as relevant to be published in Qualis of each specific 
area. Another possibility of a journal to be listed is by direct indication from the Area Representative.

Reclassification implies in the modification of a previously classified journal. This is accomplished in the first year of each three-year cycle remaining the same during that period, except in special cases when the area requests the correction or adjustment of the previous classification.

The circulation impact classification criteria (that classifies as Local, National or International) vary among the several thematic areas of CAPES. In general all areas analyze the indigenousness of the articles taking into account the authors' origin and the article impact in citation indices such as JCR (Thomson Scientific, 2007) or its acceptance by SciELO Scientific Electronic Library Online (http://www.scielo.org). Thus, it is possible to have a national journal classified as international if it had a significant value in JCR.

\section{Geographical impact of Ambiente e Água - An Interdisciplinary Journal of Applied Science (Ambi-Água)}

The Ambiente e Água Journal exercises the "golden open access" policy and search quality standard based on a large, highly qualified, peer review panel. The open access is powered by the OAI-PMH communication protocol (Batista, 2007). Figure 1 shows the countries that have frequently accessed Ambi-Água.

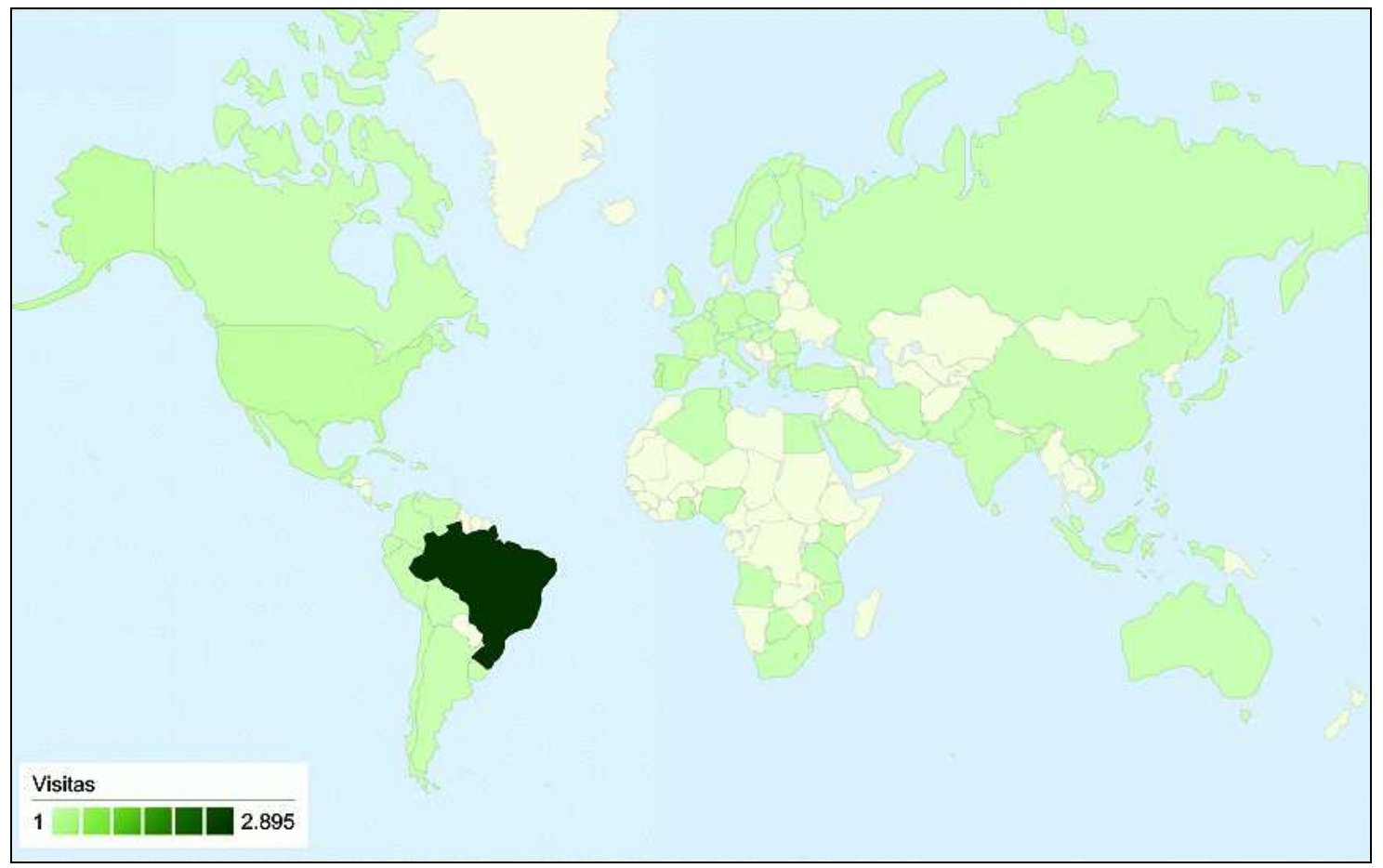

Figure 1. Countries from where Ambi-Água has been more frequently accessed in a period of 2.5 months (October $1^{\text {st }}$ to December 15, 2007). Total of 3,630 visits from 73 countries/territories.

Source: Google Analytics (2007).

Table 1 shows the number of visits from countries where Ambi-Água has been most frequently accessed. A total of 3,630 visits produces an average of 3.34 pages per visit and a medium time of 2:13 minutes per visit. 
Figure 2 shows the distribution of the cities from where the most frequent accesses came from. The 3,630 visits, in the same period, originated from 493 different cities.

Table 2 shows the cities from where the 10 most frequent accesses came from, the number of pages visited, and the average duration time of each visit.

Table 1. Frequency of access from the 10 countries from where Ambi-Água has been mostly accessed in the period of 2.5 months (October 1st to December 15, 2007).

\begin{tabular}{clrcc}
\hline $\begin{array}{c}\text { Order of } \\
\text { frequency }\end{array}$ & $\begin{array}{c}\text { Country/territor } \\
\text { y }\end{array}$ & Visits & Pages/visit & $\begin{array}{c}\text { Average time } \\
\text { in site }\end{array}$ \\
\hline 1 & Brazil & 2,895 & 3.35 & $00: 02: 14$ \\
2 & Portugal & 123 & 2.17 & $00: 00: 56$ \\
3 & United States & 99 & 3.00 & $00: 01: 02$ \\
4 & Mexico & 56 & 5.11 & $00: 04: 29$ \\
5 & Spain & 55 & 2.89 & $00: 01: 11$ \\
6 & Germany & 30 & 5.27 & $00: 02: 42$ \\
7 & United Kingdom & 29 & 4.24 & $00: 00: 53$ \\
8 & Turkey & 22 & 2.14 & $00: 00: 25$ \\
9 & China & 21 & 1.71 & $00: 02: 07$ \\
10 & Japan & 20 & 6.60 & $00: 08: 52$ \\
\hline
\end{tabular}

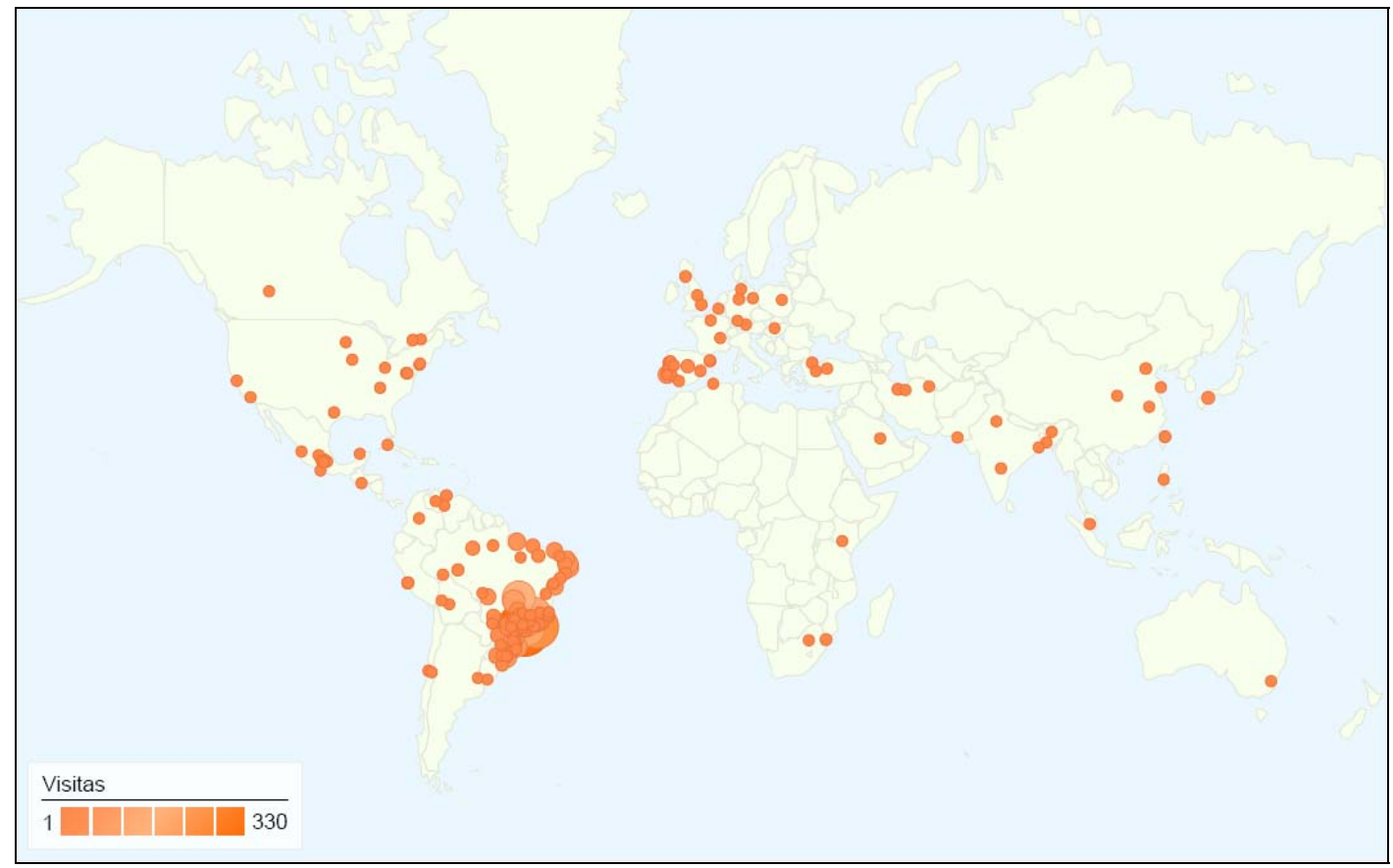

Figure 2. Cities from where Ambi-Água has been mostly frequently accessed in the period of 2.5 months (October $1^{\text {st }}$ to December 15, 2007).

Source: Google Analytics (2007).

It can be observed that visits originated in different countries or cities have different characteristics. The interpretation of those characteristics is still premature due to the short monitoring time, only 2.5 months. It is important to emphasize the functionality of this monitoring tool (Google Analytics, 2007). That system allows the analyzes of visitors' flow and it supplies a detailed report on the entrance and exit pages, and it identifies which content was more explored, at no charge. That is important for a scientific journal, because it allows, for instance, knowing which articles are being more accessed. That system also informs how the readers found the journal and how they navigated throughout its content. 
Table 2. Cities from where Ambi-Água has been mostly accessed in a period of 2.5 months (October 1st to December 15, 2007).

\begin{tabular}{clrcc}
\hline $\begin{array}{c}\text { Order of } \\
\text { frequency }\end{array}$ & \multicolumn{1}{c}{ City } & Visits & Pages/visit & $\begin{array}{c}\text { Average Time } \\
\text { in site }\end{array}$ \\
\hline 1 & São Paulo & 330 & 3.25 & $00: 01: 55$ \\
2 & Rio de Janeiro & 250 & 1.86 & $00: 01: 24$ \\
3 & Sao José dos Campos & 198 & 10.48 & $00: 08: 37$ \\
4 & Belo Horizonte & 181 & 1.97 & $00: 01: 14$ \\
5 & Brasília & 170 & 2.63 & $00: 01: 31$ \\
6 & (“not set”) & 165 & 3.18 & $00: 01: 38$ \\
7 & Goiânia & 89 & 2.17 & $00: 01: 41$ \\
8 & Florianópolis & 80 & 3.00 & $00: 02: 01$ \\
9 & Curitiba & 77 & 1.66 & $00: 00: 31$ \\
10 & Porto Alegre & 74 & 2.82 & $00: 01: 26$ \\
\hline
\end{tabular}

Another important way of evaluating the geographical impact of a scientific journal is to analyze the regional origin of the published articles, the members of the editorial board and the peer review panel. Batista (2007b) presents the ad hoc peer review panel members of the Ambi-Água, as of April, 2007, organized by State and region. The Expedient Section of this edition (Volume 2, Number 3) presents a list of current Ad Hoc Peer Reviewers of AmbiÁgua. Table 3 presents the origin of all primary authors that already published in Ambi-Água, organized by State/Country, and the institution of the first author.

Table 3. Origin of first authors that already published in Ambi-Água (Volumes 1 (2006) and 2 (2007)).

\begin{tabular}{rccc}
\hline & State/County & Institution & $\mathbf{N}^{\mathbf{0}}$ Articles \\
\hline 1 & SP & UNITAU & 9 \\
2 & SP & INPE & 8 \\
3 & SP & CSA/CTA & 1 \\
4 & SP & UNESP/FEG & 1 \\
5 & SP & UNESP/Sorocaba & 1 \\
6 & SP & IG/SMA & 1 \\
7 & SP & UFSCarlos & 1 \\
8 & SP & UNICAMP & 1 \\
9 & DF & UnB & 2 \\
10 & MG & UFUberlândia & 1 \\
11 & MG & UFV & 1 \\
12 & PA & SIVAM & 1 \\
13 & PA & UFPA & 1 \\
14 & PB & UFPB & 2 \\
15 & PR & UFPR & 1 \\
16 & RS & UFPelotas & 1 \\
17 & Cuba & Centro de Investigaciones Pesqueras & 1 \\
18 & MD/EUA & U. of Maryland & 1 \\
\hline
\end{tabular}

The indexation of a scientific journal in several international directories (Data Harvesters) increases its visibility and circulation. In addition, the publication in several languages and the presentation of an English version of all published abstracts and keywords is expected to enhance the geographic impact of a journal. Table 4 shows the directories that list Ambi-Água. As Ambi-Água is indexed by the Open Archives Initiative, any Service 
BATISTA, G. T. Geographical impact of scientific journals. Ambi-Agua, Taubaté, v. 2, n. 3, p. 12-18, 2007. (doi:10.4136/ambi-agua.29)

Providers registered in the OAI-PMH can index Ambi-Agua automatically, therefore, increasing the visibility of its published articles.

Table 4. Directories that list the journal Ambi-Água as of December of 2007.

\begin{tabular}{|c|c|}
\hline Directories of Scientific Journals & Link to Find Ambi-Água \\
\hline & $\begin{array}{l}\text { OAIster : The University of Illinois OAI-PMH Data } \\
\text { Provider Registry: } \\
\text { http://gita.grainger.uiuc.edu/registry/details.asp?id=2190 }\end{array}$ \\
\hline & $\begin{array}{l}\text { Open Journal Systems: } \\
\text { http://www.openarchives.org/Register/ListFriends } \\
\text { http://www.agro.unitau.br/seer/index.php/index/oai }\end{array}$ \\
\hline $\begin{array}{l}\text { PUBLIC KNOWLEDGE PRoJECT } \\
\text { Open Archives Harvester }\end{array}$ & $\begin{array}{l}\text { The Public Knowledge Project is a federally funded research } \\
\text { initiative at the University of British Columbia and Simon } \\
\text { Fraser University on the west coast of Canada. }\end{array}$ \\
\hline & http://livre.cnen.gov.br/ConsultaPorLetra.asp?Letra=A \\
\hline $\begin{array}{l}\text { DIRECTORY OF } \\
\text { OPEN ACCESS } \\
\text { JOURNALS }\end{array}$ & $\begin{array}{l}\text { http://www.doaj.org/doaj?func=findJournals\&hybrid= } \\
\text { \&query=Ambiente }\end{array}$ \\
\hline & http://www.latindex.unam.mx/revista.php?opcion=1 \\
\hline & http://dgb.unam.mx/periodica.html \\
\hline & http://www.socolar.com/vn.aspx?id=6545 \\
\hline
\end{tabular}

\section{FINAL CONSIDERATIONS}

It is quite evident that there is no single form to evaluate quality or geographical impact of a scientific article or journal. Perhaps, the best practice is to use several indicators and cautiously interpret them. Although restrictions do exist about the use of hit counting of access to the most popular articles of an electronic journal as indicator of the academic merit of those articles, the use of sophisticated and efficient systems such as the Google Analytics can be a tool of great value for the evaluation of on-line journals. 


\section{REFERENCES}

BATISTA, G. T. Scientific Journal Indexing. Revista Ambi-Água, Taubaté, v. 2. n. 2, p. 3-6, 2007. Disponível em: <http://www.agro.unitau.br/seer/index.php/ambi-agua/article/ view/59/80>. Acess Dec. 2007a.

BATISTA, G. T. Retrospective and perspective of Ambiente e Água after one year of publication. Revista Ambi-Água, Taubaté, v. 2. n. 1, p. 3-4, 2007. Disponível em: <http://www.agro.unitau.br/seer/index.php/ambi-agua/article/view/42/67>. Acess Dec. 2007b.

BRASIL. Ministério da Educação. Cordenação de Aperfeiçoamento de Pessoal de Nível Superior. Qualis Capes. 2007. Disponível em: <http://www.capes.gov.br/avaliacao/ webqualis.html>. Acess Dec. 2007.

BUCHANAN R. A. Science citation index expanded: the effect of journal editorial policies. The Journal of Academic Librarianship, v. 33, n. 5, p. 532-539, September 2007. DOI:10.1016/j.acalib.2007.05.001.

DEWITT, T. W.; NICHOLSON, R. S.; WILSON, M. K. Science citation index and chemistry. Journal Scientometrics, v. 2, n. 4, p. 265-275, julho 1980. Publisher Akadémiai Kiadó, co-published with Springer Science+Business Media B.V., Formerly Kluwer Academic Publishers B.V. ISSN 0138-9130 (Print) 1588-2861 (Online). DOI 10.1007/ BF02016348.

GOOGLE ANALYTICS. Disponível em: <http://www.google.com/analytics/pt-BR/>. Acess Dec. 2007.

GUPTA, H. M.; CAMPANHA, J. R.; PESCE, R. A. G. Power-law distributions for the citation index of scientific publications and scientists. Braz. J. Phys., São Paulo, v. 35, n. 4a, 2005. Disponível em: <http://www.scielo.br/scielo.php?script=sci_arttext\&pid= S0103-97332005000600012\&lng=en\&nrm=iso>. Acess Dec. 2007. DOI: 10.1590/S0103-97332005000600012.

SZKLO, M. Quality of scientific articles. Rev. Saúde Pública, São Paulo, v. 40, n. Espe., p. 30-35. 2006. Disponível em: <http://www.scielosp.org/scielo.php?script=sci_arttext\&pid= S0034-89102006000400005\&lng=en\&nrm=iso>. Acesso em: 15 Dez. 2007. DOI: 10.1590 /S0034-89102006000400005.

THOMSON SCIENTIFIC. The Science Citation Index (SCI®). 2007 . Disponível em: <http: //scientific.thomson.com/products/sci/>. Acess Dec. 2007.

WALTER G.; BLOCH S.; HUNT G.; FISHER K. Counting on citations: a flawed way to measure quality. Med. J. Aust., v. 178, p. 280-281, 2003. ISSN: 0025-729X,. Disponível em: <http://www.mja.com.au/public/issues/178_06_170303/wal10537_fm. pdf $>$. Acess Dec. 2007. 


\begin{tabular}{|c|} 
ISSN = 1980-993X - doi:10.4136/1980-993X \\
www.agro.unitau.br/ambi-agua \\
E-mail: ambi-agua@agro.unitau.br \\
Tel.: (12) 3625-4116
\end{tabular}

\title{
Soil loss prediction in Guaraíra river experimental basin, Paraíba, Brazil based on two erosion simulation models
}

(doi:10.4136/ambi-agua.30)

\author{
Richarde Marques da Silva'; Celso A. G. Santos²; Leonardo Pereira e Silva ${ }^{3}$; \\ Jorge Flávio C. B. da Costa Silva ${ }^{4}$ \\ ${ }^{1}$ Department of Geosciences, UFPB. DTI Scholar of MCT/CT-Hidro/CNPq \\ E-mail: richardemarques@yahoo.com.br \\ ${ }^{2}$ Department of Civil Engineering, Federal University of Paraíba, UFPB \\ E-mail: celso@ct.ufpb.br \\ ${ }^{3}$ Federal Center for Technological Education of Paraíba, CEFET-PB \\ E-mail: lpsjampa@yahoo.com.br \\ ${ }^{4}$ Master student of the Graduation Program in Urban Engineering - PPGEU/UFPB/CNPq \\ E-mail: jfgeo2@yahoo.com.br
}

\begin{abstract}
In this study, two hydrological models to estimate soil losses and sediment yield due to sheet and channel erosion, at the basin outlet, are applied to Guaraíra River Experimental Basin, located in Paraíba State, northeastern Brazil. The soil erosion models are (a) the classical Universal Soil Loss Equation (USLE), which is used to simulate annual and monthly soil losses; and (b) Kineros model, which is used to simulate the sediment yield within the basin. Kineros model is a physically-based distributed model that uses a cascade of planes and channels to represent the basin and to describe the processes of interception, infiltration, surface runoff and erosion within the basin. The USLE is computed using land use, soil erodibility, topographic digital maps, as well as observed rainfall data. It was found that Guaraíra river experimental basin has a low potential for soil losses; however, specific areas which are susceptible to the erosion process in the basin could be detected by the modeling techniques coupled to a GIS (Geographic Information System).
\end{abstract}

Keywords: USLE; Kineros model; ungauged basin.

\section{Predição de perdas de solo na bacia experimental do rio Guaraíra, Paraíba, Brasil usando dois modelos de simulação de erosão}

\section{RESUMO}

Neste estudo, dois modelos hidrológicos são aplicados para estimar as perdas de solo e a produção de sedimentos devido à erosão laminar e à erosão nos canais, na Bacia Experimental do Rio Guaraíra, localizada no Estado da Paraíba, região nordeste do Brasil. Os modelos usados são (a) a clássica Equação Universal de Perda de Solo (EUPS), usada para simular perdas de solo mensais e anuais; e (b) o modelo Kineros, usado nas simulações da produção de sedimentos na bacia. O Kineros é um modelo de base física, distribuído que usa uma cascata de planos e canais para representar a bacia e descrever os processos de interceptação, infiltração, escoamento e erosão na bacia. A USLE é calculada a partir de mapas digitais da bacia de uso do solo, erodibilidade, topografia e de dados diários observados de chuva. Ao final, verificou-se que a bacia experimental do rio Guaraíra tem um potencial baixo para perdas de solo; entretanto, áreas específicas susceptíveis ao processo erosivo na bacia puderam ser detectadas através de técnicas de modelagem acoplada a um SIG (Sistema de Informação Geográfica).

Palavras-chave: EUPS; modelo Kineros; bacia não-instrumentada. 


\section{INTRODUCTION}

Soil erosion by water is the most important land degradation problem worldwide, and it is a serious problem that stems from a combination of agricultural intensification, soil degradation, and intense rainstorms.

Actually, a large number of erosion models exists, which can be basically divided in two categories: empirical and physically-based models (Morgan, 1995). Empirical models have a statistical basis, whereas physically-based models intend to describe the acting processes on a storm event basis. Nevertheless, many models contain both empirical and physically-based components. A recent review of several current erosion models is provided by Merritt et al. (2003).

The empirical models are simple, but they do not penetrate into the mechanisms of the physical processes. In the case of physically-distributed models, the soil surface is subdivided into rills and interrill areas, while the soil erosion process is also analyzed into physical subprocesses.

Empirical models have been and are still used because of their simple structure and ease of application, but as they are based on coefficients computed or calibrated on the basis of measurement and/or through observed field data, as digital map or field trip, they have limited applicability outside the range of conditions for which they have been developed. Adaptation to a new environment requires a major investment of resources and time to develop the database required to drive them.

The Universal Soil Loss Equation (USLE) is the most widely used empirical erosion model (Wischmeier; Smith, 1978). It estimates soil erosion from an area simply as the product of empirical coefficients, which must therefore be accurately evaluated. Original values of such coefficients were derived from field observations in different areas within the eastern U.S., but they have been expanded with time using information gathered by researchers who have applied the USLE (and derived models) in different countries in the world e.g., ElSwaify; Dangler (1976); Dissmeyer; Foster (1981); Renard et al. (1997).

On the other hand, physically-based models simulate the individual components of the entire erosion process by solving the corresponding equations; and so it is argued that they tend to have a wider range of applicability (Amore et al., 2004). Such models are also generally better in terms of their capability to assess both the spatial and temporal variability of the natural erosion processes.

Kalin et al. (2003) investigated the effect of geomorphologic resolution on runoff hydrographs and sedigraphs over two small USDA experimental watersheds using Kineros model with ArcView interface, and they revealed that the basin geometric simplification for rainfall-runoff-erosion studies may be acceptable under right combinations of rainfall events and basin properties.

Martínez-Carreras et al. (2007) simulated badland erosion with Kineros in small microbasins in order to test the performance of the physically-based soil erosion model. Results are intended to better understand the role of summer rainstorms in annual and interannual catchment sediment yield rates, and the relevance of temporal sediment stores in the drainage network.

Prediction of runoff and erosion in ungauged hydrological basins is one of the most challenging tasks anywhere and especially a very difficult one in developing countries where monitoring and continuous measurements of these quantities are carried out in very few basins either due to the costs involved or due to the lack of trained personnel in sufficient number. Therefore, the aim of this study was the evaluation of the soil loss and sediment yield 
by the application of two models, the empirical USLE and the physically-based Kineros model, to Guaraíra river experimental basin, using a distributed approach, for further uses in ungauged basin in northeastern Brazil.

\section{MATERIAL AND METHODS}

\subsection{Study Area}

The studied area is the Guaraíra river experimental basin, which is located within Gramame river basin (Figure 1), in northeastern Brazil. This basin was chosen for the implantation of equipments in order to monitor the hydrological variables. Guaraíra river basin has an area of $5.84 \mathrm{~km}^{2}$ and it is located between the coordinates $9,190,000 \mathrm{mN}$, 9,195,000 $\mathrm{mN}$ and 274,000 $\mathrm{mE}, 277,000 \mathrm{mE}$.

MAP OF NORTHEAST GRAMAME RIVER BASIN -45 o

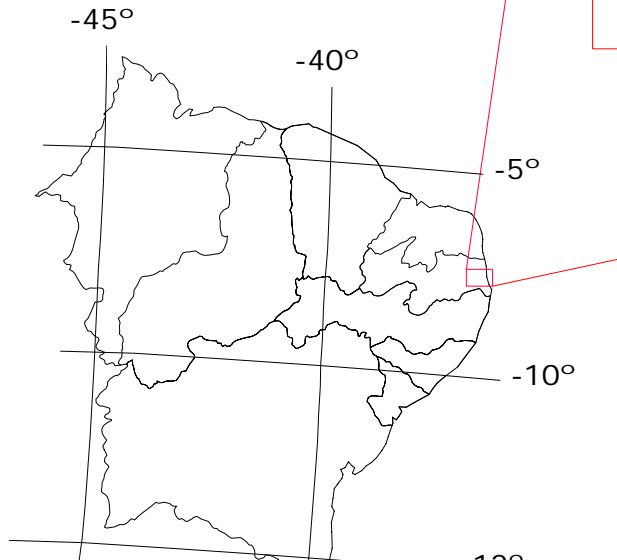

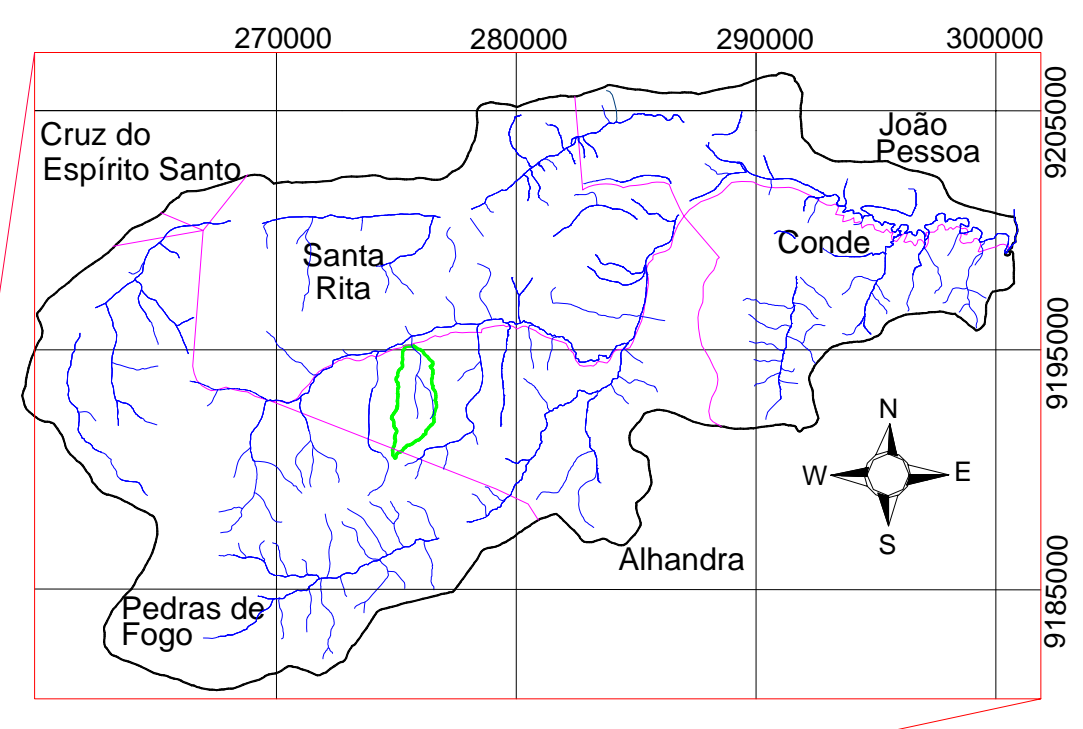

Figure 1. Location of Guaraíra river experimental basin and Gramame river basin in northeastern Brazil.

\subsection{The USLE}

Universal Soil Loss Equation (USLE) is an empirical model that was developed to predict the long term average annual rate of erosion on a field slope based on rainfall pattern, soil type, topography, crop system and management practices. USLE only predicts the amount of soil loss that results from sheet or rill erosion on a single slope and does not account for additional soil losses that might occur from gully, wind or tillage erosion. 
This erosion model was created for use in selected cropping and management systems, but is also applicable to nonagricultural conditions such as construction sites. The USLE can be used to compare soil losses from a particular field with a specific crop and management system to tolerable soil loss rates. Thus, alternative management and crop systems may also be evaluated to determine the adequacy of conservation measures in farm planning. This soil loss equation is as follows:

$A=R^{\prime} K^{\prime} L S^{\prime} C^{\prime} P$

where A is computed soil loss per unit area (usually in tons/hectare/year); $R$ is rainfall and runoff factor; $K$ is soil erodibility factor; $L S$ is the topographic factor (slope degree and length); $C$ is cover and management factor (ratio of soil loss from an area with specific cover and management to an identical area in tilled continuous fallow); $P$ is support practice factor (ratio of soil loss with a support practice factor such as contouring, terracing, etc, to a straight-row farming up and down slope).

Derivation of the factors required by USLE is well-documented in the literature (e.g., Williams; Berndt, 1976; Wischmeier; Smith, 1978; Foster et al., 1983; Desmet; Govers, 1996; Kinnell, 2005). However, the recent advent of GIS and remote sensing technology has enabled more accurate estimations of some the USLE factors, specifically those of slope length and steepness.

\subsubsection{Erosivity factor $(R)$}

The $R$ factor represents the erosivity of the rainfall at a particular location. An average annual value of $R$ is determined from historical records and is the average annual sum of the erosivity of individual storms. The $R$ factor is the average annual summation of (EI) values, and it was obtained using the Equation [2] developed by Lombardi Neto and Moldenhauer (1980), and using observed data from 2003 to 2005 from five rain gauges.

$\mathrm{EI}_{\text {monthly }}=89.823\left(\mathrm{Pm}^{2} / \mathrm{Pa}\right) 0.759$

where $\mathrm{EI}_{\text {monthly }}$ is the monthly average of the erosion index $(\mathrm{MJ} / \mathrm{ha} \times \mathrm{mm})$, for the considered month; Pm is the monthly precipitation (mm) also for the considered month; and $\mathrm{Pa}$ is the annual mean precipitation (mm). The precipitation in the basin, computed by the Thiessen method (Equation 3), and the results of the rain energy factor ( $\mathrm{EI}_{\text {monthly }}$ ) were computed for each month. Table 1 presents the locations and data range of the selected rain gauges.

$$
\bar{P}=\frac{\sum_{i=1}^{n} A_{i} P_{i}}{A_{T}}
$$

where is the mean precipitation in the basin $(\mathrm{mm})$; Ai is the polygon area assigned to $\mathrm{i}^{\text {th }}$ gauge $\left(\mathrm{km}^{2}\right)$; $\mathrm{Pi}$ is the precipitation recorded at the $\mathrm{i}^{\text {th }}$ gauge $(\mathrm{mm})$; and AT is the basin area. 
Table 1. Location and data range for the used rain gauges.

\begin{tabular}{|c|c|c|c|}
\hline Identification & Latitude & Longitude & Period of data \\
\hline Rain gauge 1 & $7^{\circ} 17^{\prime} 40 ” S$ & $35^{\circ} 02^{\prime} 34^{\prime \prime} \mathrm{W}$ & 2003-2005 \\
\hline Rain gauge 2 & $7^{\circ} 17^{\prime} 55^{\prime \prime} \mathrm{S}$ & $35^{\circ} 01^{\prime} 51^{\prime \prime} \mathrm{W}$ & 2003-2005 \\
\hline Rain gauge 3 & $7^{\circ} 18$ '51"S & $35^{\circ} 01^{\prime} 57^{\prime \prime} \mathrm{W}$ & 2003-2005 \\
\hline Rain gauge 4 & $7^{\circ}$ 17’51”S & $35^{\circ} 01^{\prime} 17^{\prime \prime} \mathrm{W}$ & 2003-2005 \\
\hline Rain gauge 5 & $7^{\circ} 17^{\prime} 71$ ”S & $35^{\circ} 01^{\prime} 25^{\prime \prime} \mathrm{W}$ & 2003-2005 \\
\hline
\end{tabular}

\subsubsection{Soil erodibility factor $(K)$}

The determination of the soil erodibility factor was based on the soil textures which exist in Guaraíra basin by using the soil map. A spatial soil distribution in the basin is shown in Figure 2 and the $K$ factor values used in the present work are presented in Table 2.

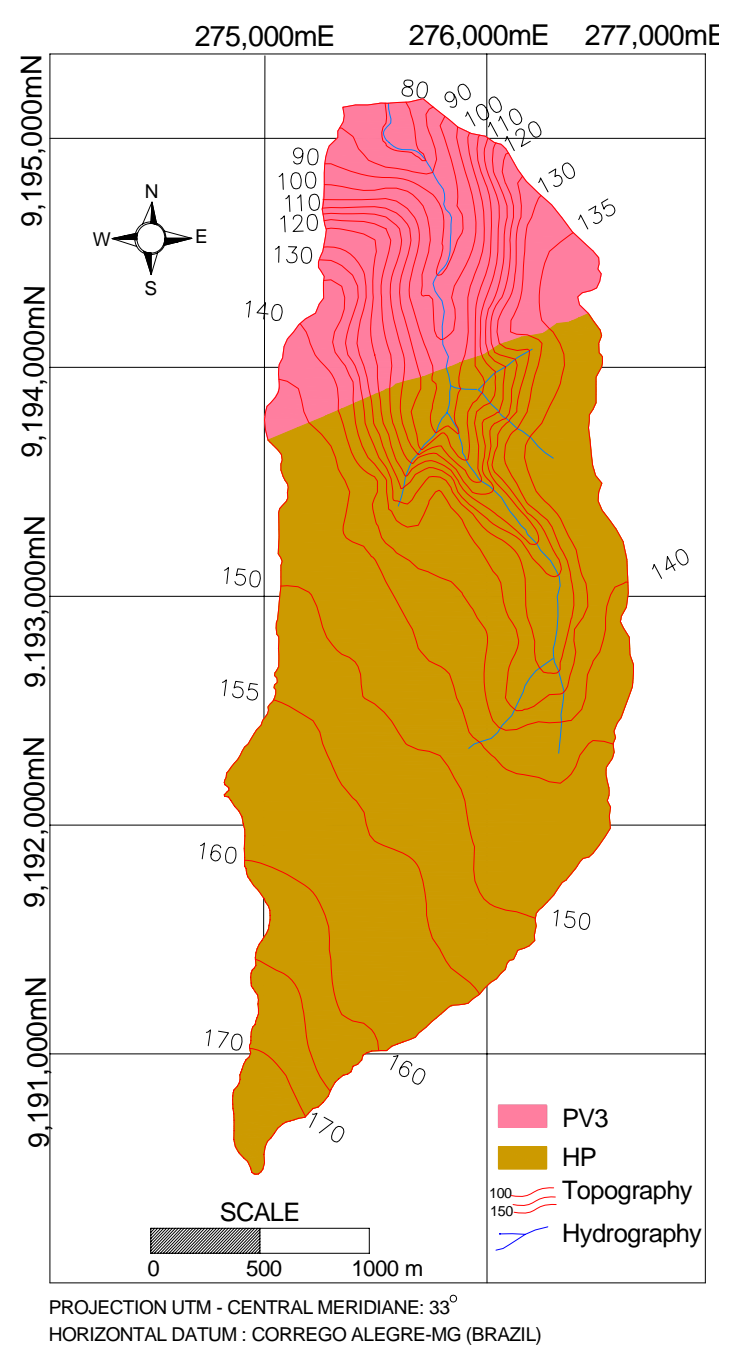

Figure 2. Topography and soil types in thee experimental basin. Source: SUDENE (1972).

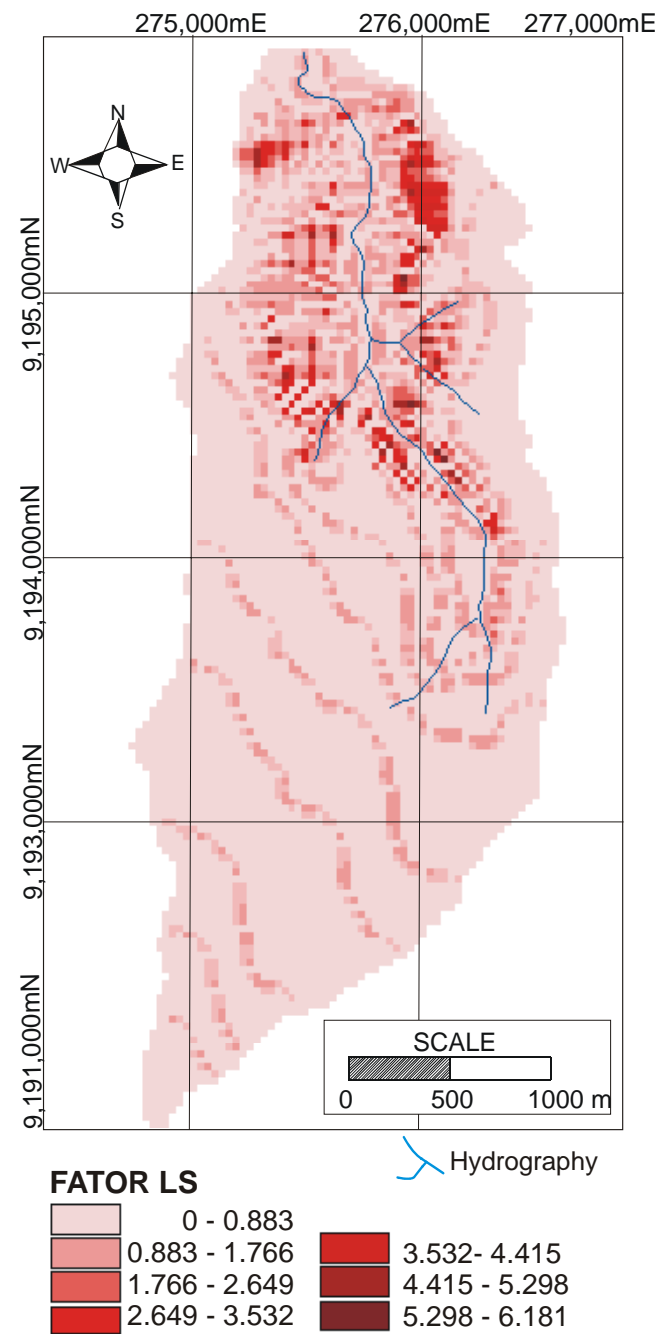

Figure 3. LS factor map computed by Equation [4] in SIG. 
SILVA, R. M.; SANTOS, C. A. G.; SILVA, L. P.; SILVA, J. F. C. B. C. Soil loss prediction in Guaraíra river experimental basin, Paraíba, Brazil based on two erosion simulation models. Ambi-Agua, Taubaté, v. 2, n. 3, p. 19-33, 2007. (doi:10.4136/ambi-agua.30)

Table 2. Values of $K$ factor according to the soil types in Guaraíra river experimental basin.

\begin{tabular}{lccc}
\multicolumn{1}{c}{ Soil types } & Texture & Class & $\begin{array}{c}\text { K } \\
(\mathbf{t} \cdot \mathbf{h a} \cdot \mathbf{h} / \mathbf{h a} \cdot \mathbf{M J} \cdot \mathbf{m m})\end{array}$ \\
\hline Podzolic Red-Yellow & Clay-Sand & PV3 & 0.032 \\
Podzol Hidromorfic & Clay & HP & 0.021 \\
\hline
\end{tabular}

\subsubsection{Topographic factor $(L S)$}

For direct application of the USLE, a combined slope-length and slope-steepness (LS) factor was evaluated for Guaraíra basin. There are several methods to determine this factor, e.g, Williams and Berndt (1976), Moore and Burch (1986), Desmet and Govers (1996), and Kinnell (2005). In this study, the LS factor was estimated from the digital elevation model (DEM). This technique for estimating the $L S$ factor was proposed by Moore and Burch (1986), which was also used by Engel and Mohtar (2007) and tested to the Brazilian conditions by Lima et al. (2006) and Souza et al. (2006), using Equation [4].

$$
L S=\left(\frac{V}{22.13}\right)^{0.4}\left(\frac{\sin \theta}{0.0896}\right)^{1.3}
$$

where $\mathrm{V}$ is runoff depth times the cell size, $\mathrm{q}$ is the slope angle in degrees.

The technique to compute $L S$ requires the values of the flow accumulation and the slope steepness. Thus, the flow accumulation and slope steepness were computed from a DEM using watershed delineation techniques. Topographic factor is one the main factors responsible for the final soil erosion caused by water when evaluated by USLE. To model the topographic factor for a watershed is necessary to quantitatively spatialize it for the entire watershed. This can be done in a GIS environment. Figure 3 shows the LS factor map of Guaraíra river experimental basin, obtained in this study.

\subsubsection{Cropping $(C)$ and support practice $(P)$ factors}

The Cropping and Management Factor $(C)$ for the USLE is defined as the ratio of soil loss from a particular cropping and management to soil loss from a continuously tilled fallow area. Earlier, $C$ values had been defined as the ratio for a particular cropping and management to soil loss from a continuously tilled fallow area or to soil loss from a conventionally tilled row cropped area. Figure 4 presents the topography and land uses founded in Guaraíra basin.

The conservation practices factor $(P)$ is the ratio of soil loss for a specific practice to the soil loss with up-and-down hill culture. The initial practices considered for the USLE were contouring, strip-cropping, contour strip-cropping, and terraces. These were expanded to include contour listing, controlled-row grade ridge planting, contoured residue strips, and several types of terraces. Most $P$ values were recognized to have slope-length limits and to have values that varied according to the land slope.

Finally, USLE equation basically expresses soil loss per unit area due to rainfall. It does not include wind erosion, and it does not give direct sediment yield estimates (Fistikoglu; Harmancioglu, 2002). Since all factors in the USLE equation have a spatial distribution in a watershed, a GIS-based evaluation gives more accurate results. In the GIS assisted approach (Figure 5), each equation factor is described in the form of digital maps, and five digital layers of the equation are overlaid in order to obtain spatially distributed soil loss in a watershed. 
SILVA, R. M.; SANTOS, C. A. G.; SILVA, L. P.; SILVA, J. F. C. B. C. Soil loss prediction in Guaraíra river experimental basin, Paraíba, Brazil based on two erosion simulation models. Ambi-Agua, Taubaté, v. 2, n. 3, p. 19-33, 2007. (doi:10.4136/ambi-agua.30)

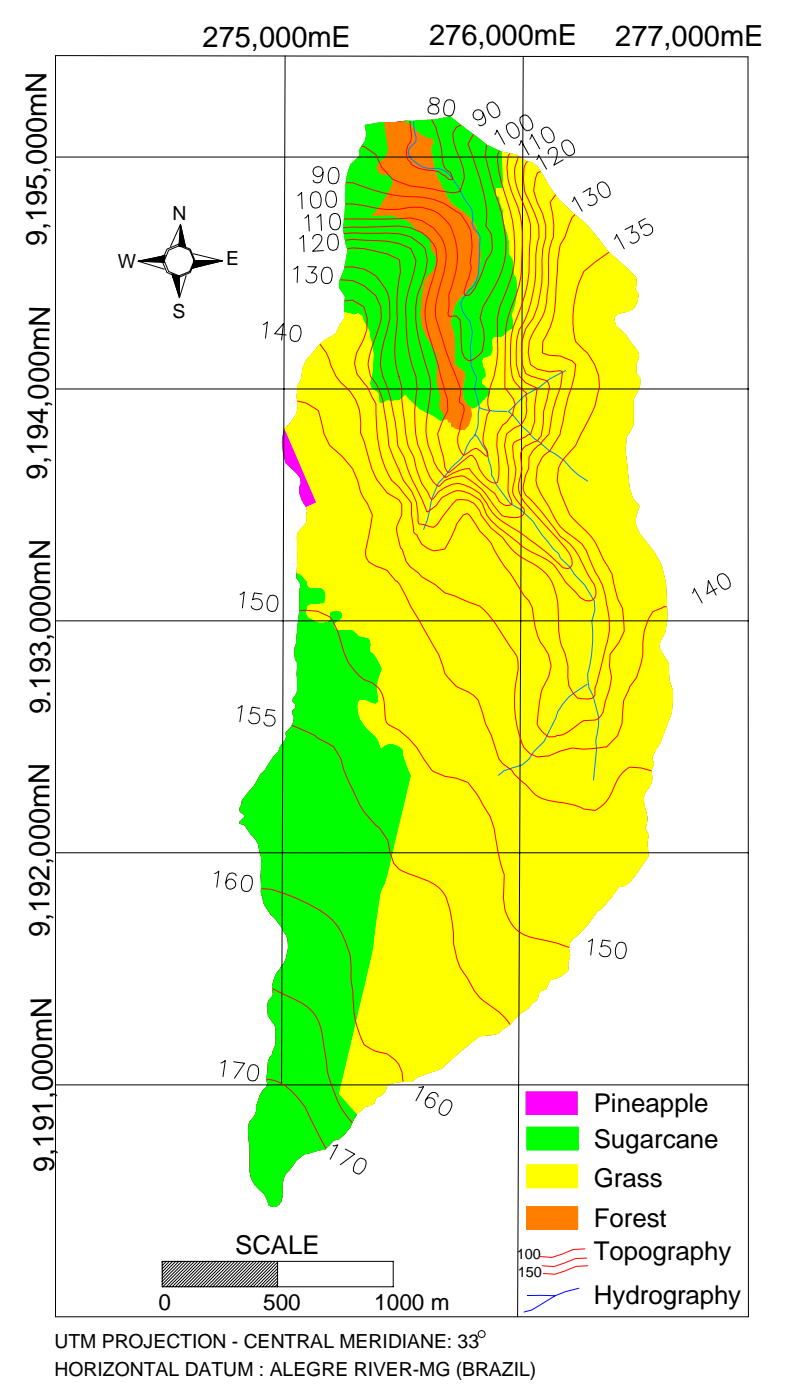

Figure 4. Topography and land use in basin.

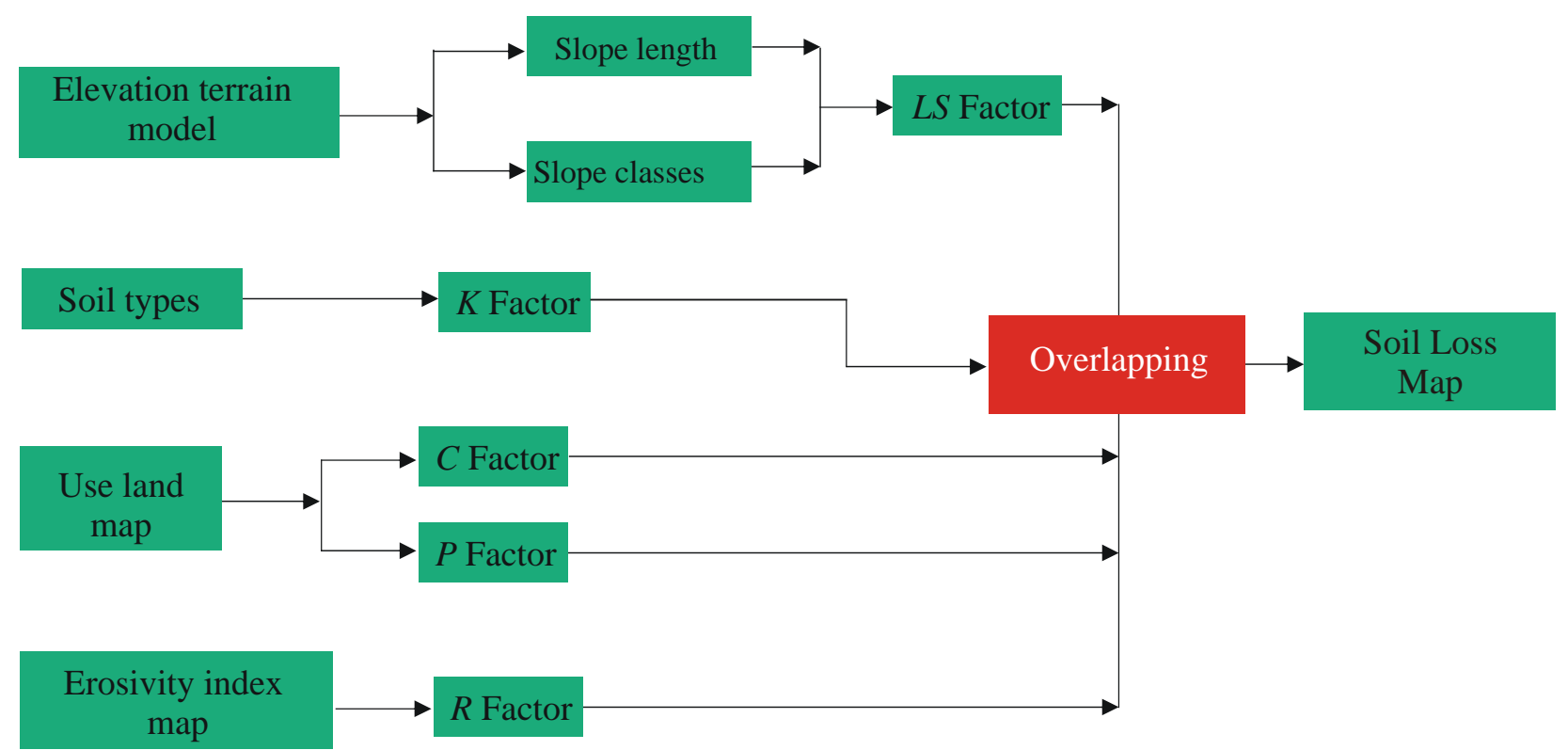

Figure 5. Steps in estimation of soil loss by USLE. 


\subsection{The Kineros model}

Kineros model (Woolhiser et al., 1990) is a distributed kinematic physically-based runoff-erosion model that uses a cascade of planes and channels to represent the water path in the basin. Kineros model inputs assume rectangular hillslope areas being laterally contributed by water and sediment and/or to the top of channel segments (Figure 6).

This model is also an event-oriented model which describes the processes of interception, infiltration, surface runoff and erosion from small agricultural and urban basins. As stated before, the basin is represented by a cascade of planes and channels, in which the partial differential equations describing overland flow, channel flow, erosion and sediment transport are solved by finite difference techniques. Furthermore, the spatial variation of rainfall, infiltration, runoff, and erosion parameters can be also accommodated.

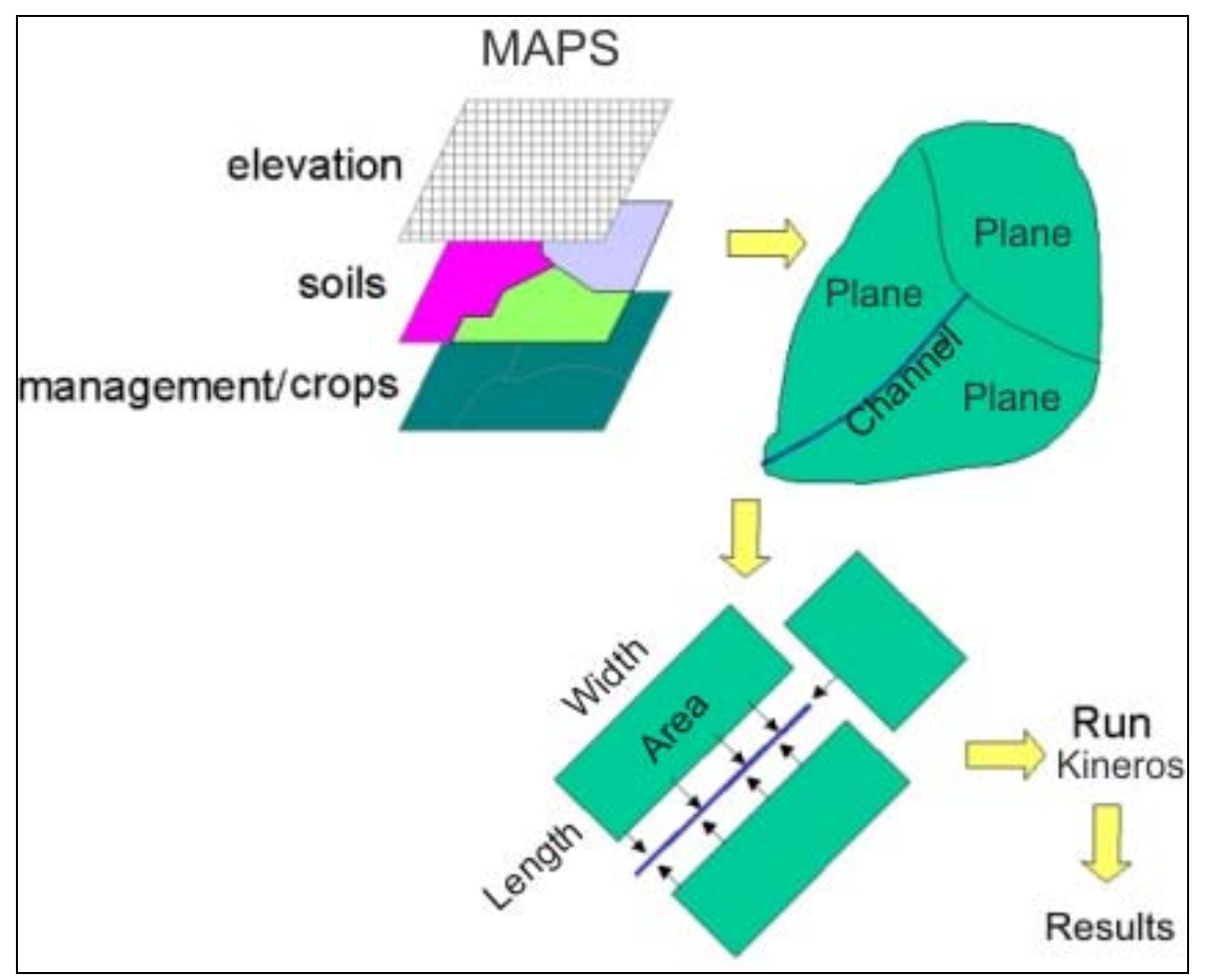

Figure 6. Steps in discretizing a watershed for a Kineros model simulation.

Thus, the Kineros model was selected as the physically-based model to be used during this study. This model is primarily useful for predicting surface runoff and erosion over small agricultural and urban watersheds. Runoff is calculated based on the Hortonian approach and infiltration is calculated by Smith and Parlange (1978) infiltration model. It requires the watershed to be divided into homogeneous overland flow planes and channel segments, and it models water movement over these elements in a cascading fashion. One-dimensional flow discharge per unit width, $q$, is expressed in terms of the storage of water per unit area, $h$ (equal depth for a plane surface), through the kinematic approximation:

$q=a h^{m}$ 
where a and $\mathrm{m}$ are parameters related to the slope roughness and nature of flow. The continuity equation for upland areas is:

$$
\frac{\partial A}{\partial t}+\frac{\partial q}{\partial x}=q_{c}(x, t)
$$

where $\mathrm{t}$ is time, $\mathrm{x}$ is the spatial coordinate, and qc is the net lateral inflow rate. The upstream condition is determined by the flow entering at the upstream end. The continuity equation for one-dimensional flow in channels is:

$$
\frac{\partial A}{\partial t}+\frac{d Q}{d A} \frac{\partial A}{\partial x}=q_{c}(x, t)
$$

where A is flow cross-sectional area, Q is the channel discharge, and qc is the net lateral inflow per unit length of channel. Under the kinematic wave approximation.

Erosion and sediment transport rates are determined by solution to the sediment balance relation:

$$
\frac{\partial\left(A C_{s}\right)}{\partial t}+\frac{\partial\left(Q C_{s}\right)}{\partial x}-w_{e}\left(x, t, C_{s}\right)=q_{c}(x, t)
$$

in which Cs is the sediment concentration $\left(\mathrm{m}^{3} / \mathrm{m}^{3}\right)$, e is the local rate of erosion or deposition $\left(\mathrm{m}^{3} / \mathrm{s} / \mathrm{m}^{2}\right)$, q is the rate of sediment inflow, as for lateral inflow to a channel.

Erosion rate e is composed of rainsplash erosion, es (r, h), and hydraulic erosion, eh. Splash erosion is a function of rainfall energy, often related to the square of rainfall intensity. Kineros relates es to the rainfall rate, $r$, the fraction of covered soil, , and mean runoff depth :

$$
\mathrm{e}_{\mathrm{s}}=S_{p l}(1-\gamma) \exp \left(-c_{d} \bar{h}\right) r^{2}
$$

Parameter Spl represents soil vulnerability to rainfall detachment, and cd represents the effect of water depth in damping splash energy. The exponent function expresses a reduction in es with increasing depth of surface water, reflecting its dampening effect on splash energy.

Hydraulic erosion may be positive or negative (deposition), depending on the local transport capacity. Transport capacity is assumed to represent a concentration, $\mathrm{Cm}$, in which erosion and deposition rates are in balance and eh is 0 , assuming there is no resistance to particle entrainment. Deposition is theoretically related to settling velocity, vs, and thus a relation for eh may be found:

$$
e_{h}=C_{h} v_{s}\left(C_{m}-C_{s}\right)
$$

in which, the coefficient $C h$ is inversely related to soil cohesion or any other restriction on soil entrainment by flowing water, and is 1 during deposition ( $\mathrm{Cs}>\mathrm{Cm}$ ). $\mathrm{Cm}$ is estimated in Kineros by a modified form of the Engelund and Hansen transport relation (Kalin et al., 2003). 


\subsection{Kineros model calibration}

The parameters that have the strongest influence on runoff from a land cover perspective for Kineros are saturated hydraulic conductivity (Ks), porosity ( $f$ ), canopy cover, and Manning's roughness coefficient. These parameters were adjusted for each layer, according to the soil types found in the basin and also based on the mean values proposed by Green-Ampt (Rawls et al., 1991). Other parameters such as mean soil capillarity drive $(G)$, mean microtopographic spacing $\left(S_{p}\right)$, volumetric rock fraction $(R)$ were based on either field observation or digital maps, as shown in Tables 3 and 4. After that, the obtained simulation results were inserted into a GIS.

Table 3. Parameters for the soil upper layer used in the calibration process.

\begin{tabular}{lcc}
\hline \multicolumn{1}{c}{ Parameters } & Symbol & Upper layer \\
\hline Thickness of upper soil layer & $H$ & $400-550 \mathrm{~mm}$ \\
Mean microtopographic spacing & $S_{p}$ & $0.1-0.3 \mathrm{~m}$ \\
Rainfall splash coefficient & $C_{f}$ & 50 \\
Soil cohesion coefficient & $C_{o}$ & 0.5 \\
Fraction of surface covered by canopy & $C_{s}$ & $2-4$ \\
Initial degree of soil saturation & $\theta_{s i}$ & $0.4-0.7$ \\
Manning roughness coefficient & $n$ & $0.02-0.005$ \\
\hline
\end{tabular}

Table 4. Parameters for the two-layers soil profile used in the calibration process.

\begin{tabular}{lccc}
\hline \multicolumn{1}{c}{ Parameters } & Symbol & Upper layer & Lower layer \\
\hline Mean capillary drive & $G$ & $20-25 \mathrm{~mm}$ & $12-16 \mathrm{~mm}$ \\
Saturated hydraulic conductivity of the soil & $K_{s}$ & $2.2-3.0 \mathrm{~mm} / \mathrm{h}$ & $1.8-2.0 \mathrm{~mm} / \mathrm{h}$ \\
Pore size distribution index & $\lambda$ & $0.29-0.32$ & $0.16-0.18$ \\
Volumetric rock fraction & $R_{o}$ & $0.0-0.0$ & $0.0-0.1$ \\
Porosity & $\phi$ & $0.32-0.40$ & $0.16-0.24$ \\
\hline
\end{tabular}

\section{RESULTS AND DISCUSSION}

\subsection{Application of Kineros model to the Guaraíra basin}

Figure 7 illustrates the geometric abstraction of a watershed into channel and plane elements, which are 30 overland flow subareas and 9 channel sections for simulation purposes. As the illustration suggests, this subdivision was performed along streamlines, and the elements were selected to distinguish and conserve the management areas indicated in the furnished maps through the geoprocessing techniques. These subareas were treated as rectangles of equivalent area, when the length and mean slope were preserved.

This subdivision was a compromise, in so far as some local slope variations could have been represented only by using far more elements. It was later learned that furrow directions in some cases did not match the topographic trend, which would affect the derivation of slope and flow length for areas with significant furrow depths. The data did not specify furrow geometries, which were assumed according to crop type. 


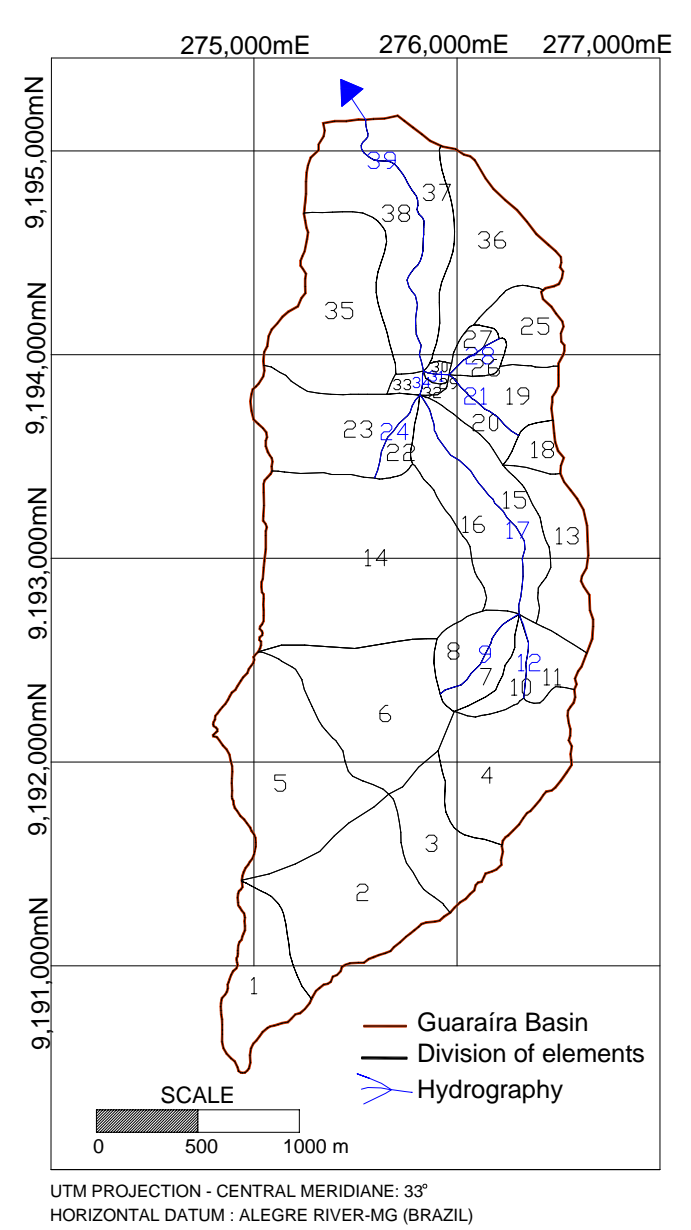

(a)

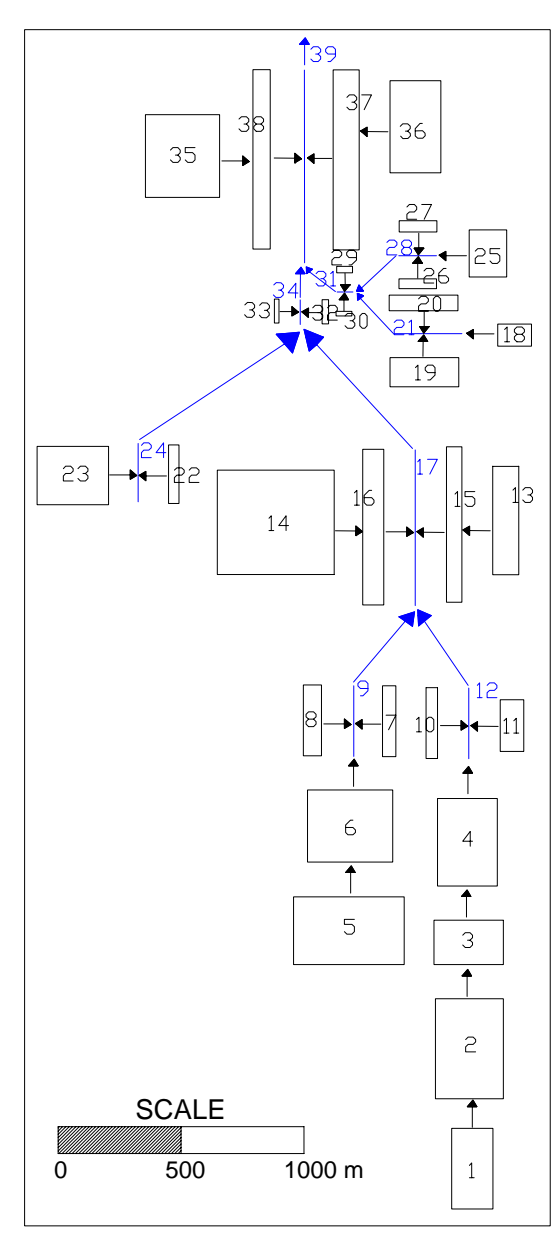

(b)

Figure 7. (a) Lateral boundaries of the elements in which the Guaraíra basin was subdivided for Kineros, and (b) basin scheme in plane and channel elements. It was assumed, in the absence of detail on furrow depth and direction, that flow follows topographic directions.

\subsection{Estimation of soil loss and sediment yield in Guaraíra basin}

The estimation of soil loss was calculated through overlapping of all the maps of $R, K$, $L S, C$ and $P$, which were integrated to generate the erosion map to find out the spatial distribution of soil loss within GIS environment for the Guaraíra river basin. The average rainfall erosivity factor $(R)$ for the years 2003, 2004 and 2005 was found to be 528 $(\mathrm{MJ} / \mathrm{ha} \times \mathrm{mm})$. Thus, Figure 8 shows soil loss in the Guaraíra basin using USLE, expressed in five broad classes and ranging from 0.0 up to 3.2 ton/ha/year, which can be considered as very low risk areas. The mean annual soil loss rate can be assumed as around 1.6 ton/ha/year.

Figure 9 presents the computed sediment yield in Guaraíra basin in four classes, using Kineros model, in which the mean annual soil loss rate can be in the oder of 2.8 ton/ha/year. The sediment yield in the area during those analyzed years can be considered of moderate magnitude, mainly due to the small area of basin.

In addition, Figure 10 presents the mean precipitation and the $\mathrm{EI}_{\text {monthly, which are }}$ monthly computed in the basin. From this relationship, it is observed that the largest values of erosivity and rainfall, in Guaraíra basin, were observed from May to July (around 57\%). Even taking into account the wide spatial diversity and limitations in the data, it was found that, in general, the USLE can be used to predict soil loss in the basin. As the Figure 11 shows, the erosion depends mainly on the precipitation depth and a relationship could be done as shown in the same Figure. 
SILVA, R. M.; SANTOS, C. A. G.; SILVA, L. P.; SILVA, J. F. C. B. C. Soil loss prediction in Guaraíra river experimental basin, Paraíba, Brazil based on two erosion simulation models. Ambi-Agua, Taubaté, v. 2, n. 3, p. 19-33, 2007. (doi:10.4136/ambi-agua.30)

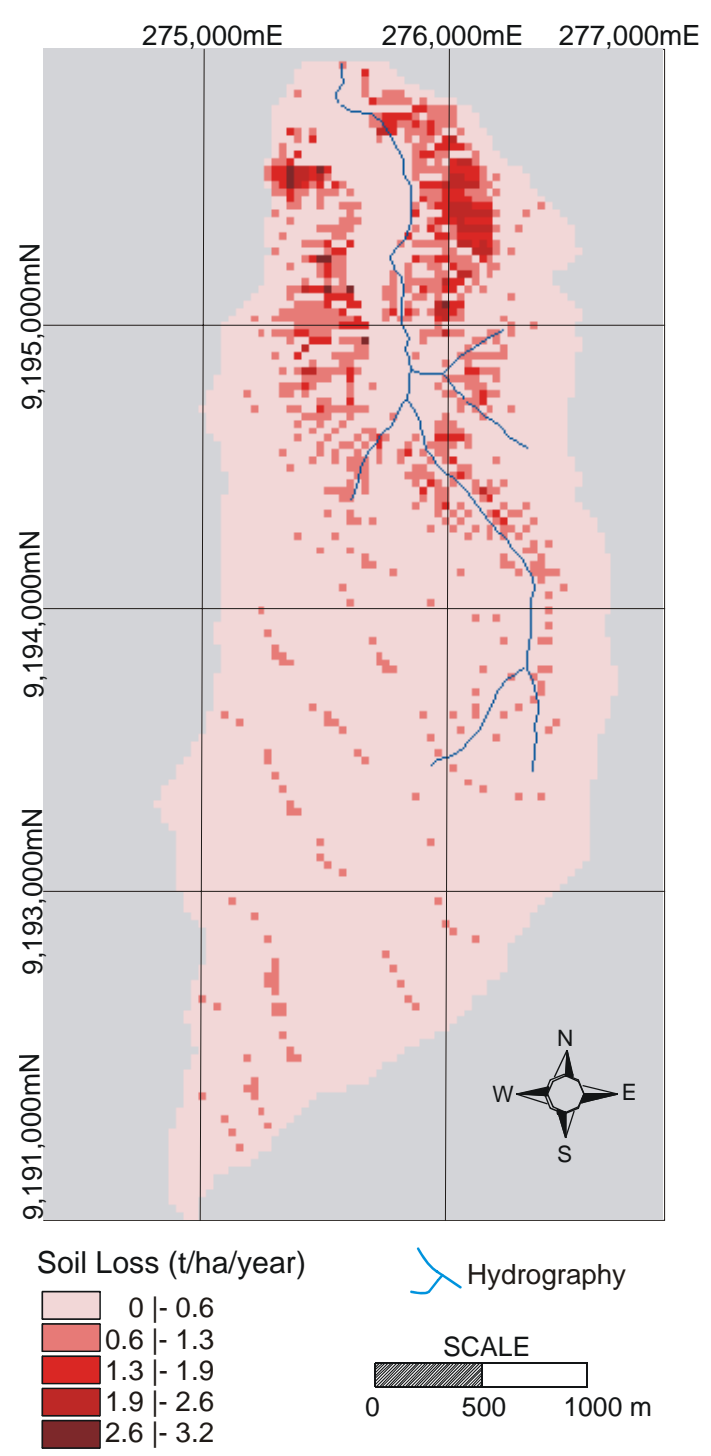

Figure 8. Estimation of soil loss using USLE in Guaraíra basin.

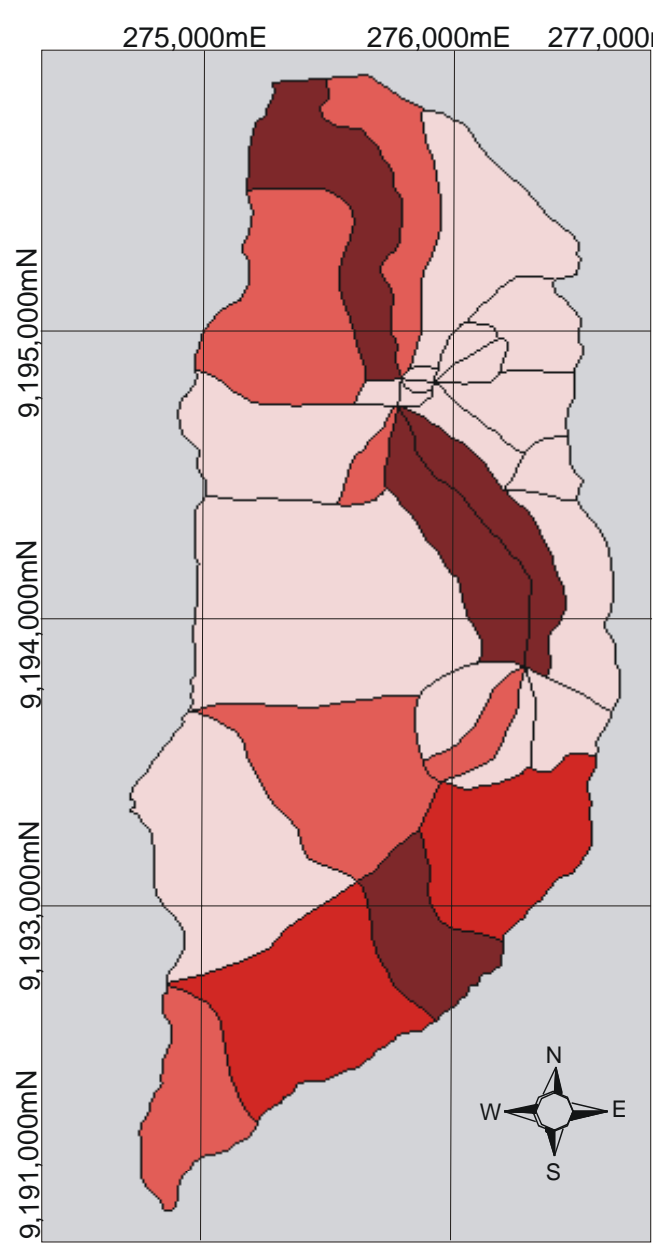

Sediment yield (t/ha/year)
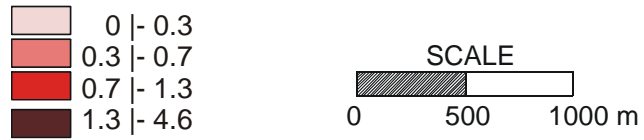

Figure 9. Estimation of sediment yield using Kineros model.

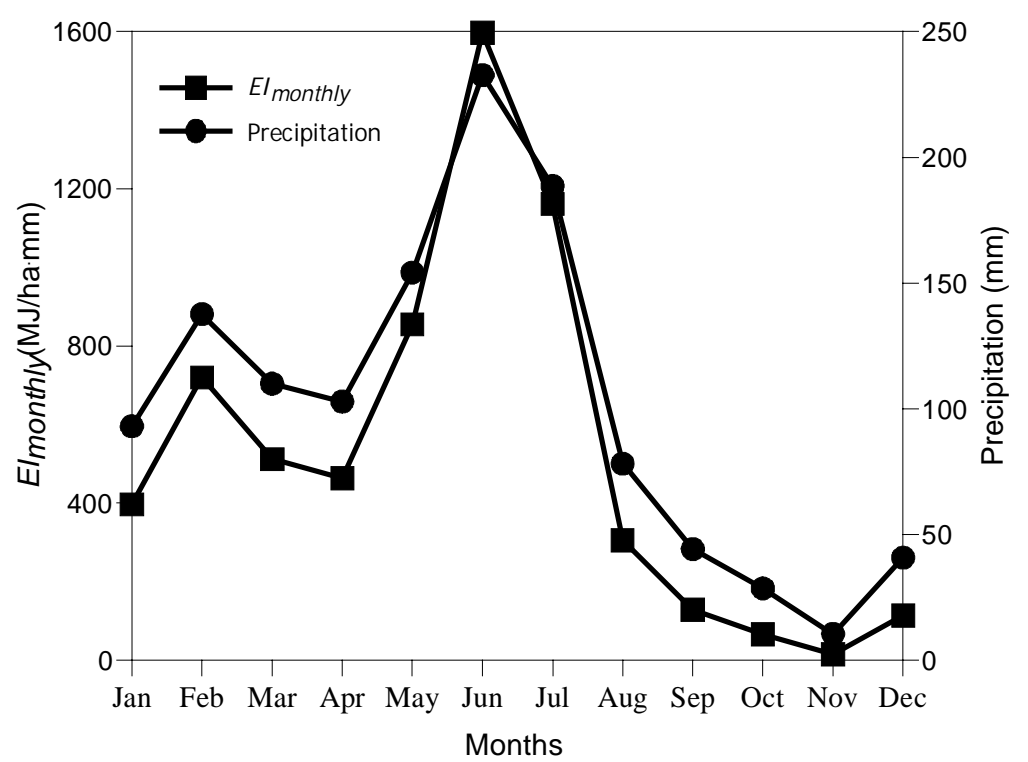

Figure 10. Rainfall erosivity and annual precipitation distribution in Guaraíra basin. 


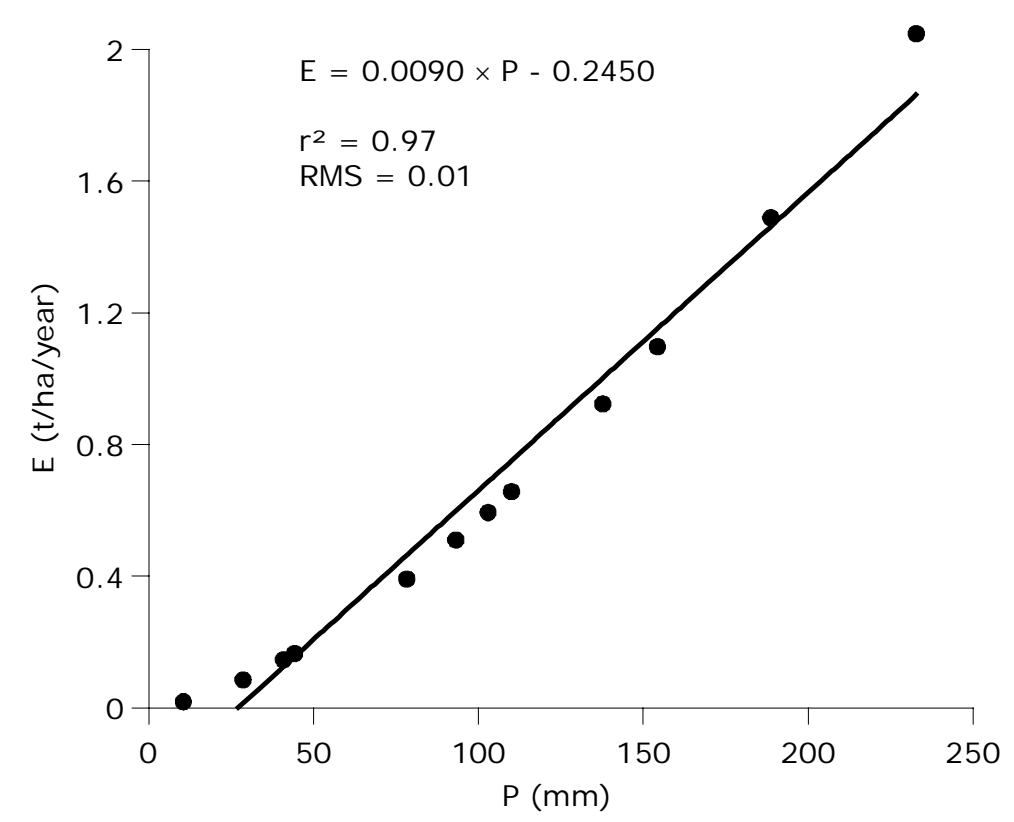

Figure 11. Relationship between mean annual precipitation $(P)$ and soil loss computed by USLE $(E)$.

\section{CONCLUSIONS}

In this paper, it was shown the integration of USLE and Kineros model with GIS in order to model the soil erosion potentialities in an ungauged basin named Guaraíra river experimental basin, located in northeastern Brazil. The simulation results have demonstrated the importance of detailed hydrologic information to successful erosion simulation.

Results obtained in this paper are preliminary, thus the models should be calibrated and verified by further field research. However, the study showed that GIS allows more effective and accurate applications of the USLE and Kineros models for basin with available spatial data. The soil loss results, simulated by the USLE, showed that these losses within the basin ranged from 0 to 3.2 ton/ha/year and that the period from May to July presents the greatest losses while the period from September to December shows the smallest ones. In the Kineros modeling, the sediment yield was estimated in the order of 0 to 4.6 ton/ha/year for the same period, and the susceptible areas to the erosion process are well determined. In general, the Guaraíra river experimental basin shows a soil loss potential which could be considered as very low for the studied period; however, special attention must be taken from May to July mainly on those areas indicated by this study.

\section{ACKNOWLEDGEMENTS}

This research was financially supported by MCT/CT-Hidro/CNPq (n. 13/2005), and the authors are also CNPq scholars.

\section{REFERENCES}

AMORE, E.; MODICA, C.; NEARING, M. A.; SANTORO, V. C. Scale effect in USLE and WEPP application for soil erosion computation from three Sicilian basins. Journal of Hydrology, Amsterdam, v. 293, p. 100-114, 2004. 
DESMET, P. J. J.; GOVERS, G. A GIS procedure for automatically calculating the USLE LS factor on topographically complex landscape units. Journal of soil and Water Conservation, Ankeny, v. 51, n. 5, p. 427-433, 1996.

DISSMEYER, G. E.; FOSTER, G. R. Estimating the cover management factor $(C)$ in the Universal Soil Loss Equation for forest conditions. Journal of soil and Water Conservation, Ankeny, v. 36, n. 4, p. 235-240, 1981.

EL-SWAIFY, S. A.; DANGLER, E. W. Erodibility of selected tropical soils in relation to structural and hydrological parameters. In: SOIL CONSERVATION SOCIETY OF AMERICA. Soil conservation. Ankeny: SCSA, 1976. p. 105-114.

ENGEL, B.; MOHTAR, R. Estimating soil erosion using RUSLE and the ArcView GIS. Web Conference... Disponível em: <http://pasture.ecn.purdue.edu/ abe526/resources1/ workshop>. Acesso em: 01 mar. 2007.

FISTIKOGLU, O.; HARMANCIOGLU, N. B. Integration of GIS with USLE in assessment of soil erosion. Water Resources Management, Athens, v. 16, p. 447-467, 2002.

FOSTER, G. R.; SMITH, R. E.; KNISEL, W. G.; HAKONSON, T. E. Modeling the effectiveness of on-site sediment controls. ASAE, paper 83-2092, 1983.

KALIN, L.; GOVINDARAJU, R. S.; HANTUSH, M. M. Effect of geomorphologic resolution on modeling of runoff hydrograph and sedimentograph over small watersheds. Journal of Hydrology, Amsterdam, n. 276, p. 89-111, 2003.

KINNELL, P. I. A. Alternative approaches for determining the USLE-M slope length factor for grid cells. Soil Science Society of America Journal, Ankeny, n. 69, p. 674-680, 2005.

LIMA, J. E. F. W.; EID, N. J.; SILVA, E. M.; MARTINS, E. S.; LOPES, W. T. A.; KOIDE, S. Preliminary evaluation of erosion potential in the Alto Jardim River Basin, Federal District, Brazil. In: ECONTRO NACIONAL DE ENGENHARIA DE SEDIMENTOS, 7., 2006, Porto Alegre. Proceedings... Porto Alegre: ABRH, 2006.

LOMBARDI NETO, F.; MOLDENHAUER, W. C. Erosividade da chuva: sua distribuição e relação com perdas de solo em Campinas, SP. In: ENCONTRO NACIONAL DE PESQUISA SOBRE CONSERVAÇÃO DO SOLO, 3., 1980, Recife. Proceedings... Recife: UFRPE, 1980. p. 1-13.

MARTÍNEZ-CARRERAS, N.; SOLER, M.; HERNÁNDEZ, E.; GALLART, F. Simulating badland erosion with KINEROS2 in a small Mediterranean mountain basin (Vallcebre, Eastern Pyrenees). Catena, [S.l.], n. 71, p. 145-154, 2007.

MERRITT, W. S.; LETCHER, R. A.; JAKEMAN, A. J. A review of erosion and sediment transport models. Environmental Modelling \& Software, Canberra, v. 18, n. 8, p. 761-799, 2003.

MOORE, I. D.; BURCH, G. Physical basis of the length-slope factor in the Universal Soil Loss Equation. Soil Science Society of America Journal, [S.1.], n. 50, p. 1294-1298, 1986.

MORGAN, R. P. C. Soil Erosion and Conservation. Essex: Longman Group, 1995. 198 p. 
RAWLS, W. J.; AHUJA, L. R.; BRAKENSIEK, D. L.; SHIRMOHAMMADI, A. Infiltration and soil water movement. In: MAIDMENT, D. R. (ed.) Handbook of hydrology. New York: McGraw-Hill, 1991. 51 p.

RENARD, K.G.; FOSTER, G. R.; WEESIES, G. A.; MCCOOL, D. K.; YODER, D. C. Predicting soil erosion by water: a guide to conservation planning with the Revised Universal Soil Loss Equation. In: U.S. Department of Agriculture. Agricultural Handbook. Washington: USDA, 1997. 404 p. vol. 703.

SMITH, R. E.; PARLANGE, J. Y. A parameter efficient hydrologic infiltration model. Water Resources Research, [S.l.], n. 14, p. 553-538, 1978.

SOUZA, C. F.; DORNELLES, A. M.; ACIOLI, L. A.; MERTEN, G. Comparison between estimation of sediment yield in the Potiribu River Basin. In: ENCONTRO NACIONAL DE ENGENHARIA DE SEDIMENTOS, 7., 2006, Porto Alegre. Proceedings... Porto Alegre: ABRH, 2006.

SUPERINTENDENCIA DO DESENVOLVIMENTO DO NORDESTE - SUDENE. Levantamento exploratório-reconhecimento de solos do Estado da Paraíba. Recife: SUDENE, 1972

WILLIAMS, J. R.; BERNDT, H. D. Determining the universal soil loss equation's length-slope factor for watersheds. In: NATIONAL SOIL EROSION CONFERENCE, 1976, Lafayette. Proceedings... West Lafayette: [S.n.], 1976. p. 34-45.

WISCHMEIER, W. H.; SMITH, D. D. Predicting rainfall erosion losses. In: U.S. Department of Agriculture. Agriculture handbook. Washington: USDA, 1978. 58 p. vol. 357.

WOOLHISER, D. A.; SMITH, R. E.; GOODRICH, D. C. Kineros, a kinematic runoff and erosion model: documentation and user manual. In: U.S. Department of Agriculture. Agricultural Research Service. Washington: USDA, 1990. 130 p. vol. 77. 


\title{
Ecotoxicological evaluation of leachate from the Limeira sanitary landfill with a view to identifying acute toxicity
}

(doi:10.4136/ambi-agua.31)

\author{
Núbia Natália de Brito-Pelegrini ${ }^{1}$; Ronaldo Teixeira Pelegrini ${ }^{2}$; \\ José Euclides Stipp Paterniani ${ }^{1}$ \\ ${ }^{1}$ Universidade Estadual de Campinas, Faculdade de Engenharia Agrícola - UNICAMP - FEAGRI \\ E-mail: núbia.brito@agr.unicamp.br; pater@agr.unicamp.br \\ ${ }^{2}$ Centro Superior de Educação Tecnológica - CESET - UNICAMP \\ E-mail: pelegrini@ceset.unicamp.br
}

\begin{abstract}
Final disposal of solid waste is still a cause for serious impacts on the environment. In sanitary landfills, waste undergoes physical, chemical, and biological decomposition, generating biogas and leachate. Leachate is a highly toxic liquid with a very high pollution potential. The purpose of this work is to evaluate toxicity of in natura leachate samples collected from Limeira Sanitary Landfill, in Limeira, SP. The ecotoxicological evaluation comprised acute toxicity assays using as test organisms Daphnia Similis, seeds of Eruca sativa (arugula), and Allium cepa roots (onion). Analyses of color, $\mathrm{pH}$, turbidity, conductivity, hardness, nitrogen, total organic carbon (TOC), adsorbable organic halogen (AOX), and metals were also carried out. The main results for Eruca sativa (arugula) and Allium cepa (onion) indicated that the diluted leachate $50 \%$ presented similar toxicity to the phenol solution of $1000 \mathrm{mg} . \mathrm{L}^{-1}$ for arugula and $2000 \mathrm{mg} . \mathrm{L}^{-1}$ for onion. With the solution of $\mathrm{Cr}^{+6}$ concentrations of $3000 \mathrm{mg} . \mathrm{L}^{-1}$ for arugula and $2000 \mathrm{mg} . \mathrm{L}^{-1}$ for onion were found. For analyses with Daphnia Similis the EC50 was 9.3\% on average. This way it was possible to observe that biological tests are necessary to evaluate the pollution in the effluents or water bodies. These tests serve to determine the toxic potential of a chemical agent or complex mixture.
\end{abstract}

Keywords: acute toxicity; waste leachate; toxicity evaluation; sanitary landfill.

\section{Avaliação ecotoxicológica do percolado do aterro sanitário de Limeira visando à identificação da toxicidade aguda}

\section{RESUMO}

A disposição final de resíduos sólidos é uma prática que ainda traz sérios impactos ao meio ambiente. Nos aterros sanitários, os resíduos passam por processos físicos, químicos e biológicos de decomposição, gerando biogás e percolado. O percolado é um liquido com elevado potencial poluente e alta toxicidade. Este trabalho tem como objetivo o estudo da avaliação da toxicidade realizada em amostras de percolado ("in natura”) coletadas no Aterro Sanitário de Limeira-SP. A avaliação ecotoxicológica foi realizada através de testes de toxicidade aguda utilizando como organismos testes: Daphnia Similis, sementes de Eruca sativa (rúcula) e Allium cepa (cebola). Foram realizados também análises de Cor, pH Turbidez, Condutividade, Dureza, Nitrogênio, Carbono Orgânico Total (TOC), Halogênios Organicamente ligados (AOX) e Metais. Os principais resultados para Eruca sativa (rúcula) e 
Allium cepa (cebola) indicaram que o percolado diluído 50\% apresentou toxicidade similar a solução de fenol de $1000 \mathrm{mg} . \mathrm{L}^{-1}$ para rucúla e $2000 \mathrm{mg} . \mathrm{L}^{-1}$ para cebola. Com a solução de $\mathrm{Cr}^{+6}$ as concentrações encontradas foram de $3000 \mathrm{mg} . \mathrm{L}^{-1}$ para rúcula e $2000 \mathrm{mg} . \mathrm{L}^{-1}$ para cebola. Para as análises com Daphnias similis o CE50 foi, em média, de 9.3\%. Dessa forma foi possível observar que para avaliação da poluição dos efluentes ou corpos hídricos é necessário a utilização de testes biológicos por meio dos quais se determina o potencial tóxico de um agente químico ou de um mistura complexa.

Palavras-Chave: toxicidade aguda; percolado de aterro; avaliação da toxicidade; aterro sanitário.

\section{INTRODUCTION}

The final disposition of solids waste is a practice that still brings serious impacts to the environment, generating polluting byproducts such as leachate, a dark-colored, strongsmelling, highly toxic liquid. Leachate originates from the decomposition of organic matter, the intensity of pluvial waters, and other liquids derived from waste (Bertazzoli; Pelegrini 2002).

The toxicity and impact provoked for the Leachate on microflora and microfauna is very strong and they are influenced by various factors such organic matter, heavy metals and nitrogen concentrations, as well as mass flux of contaminants being transported (Isidori et al., 2003). Identifying compounds that cause the toxicity in the leachate is not easy because the physical-chemical characteristic of leachate is highly variable and dependant on the following factors: local environment conditions, time elapsed after waste disposal and landfill characteristics as well (Bertazzoli; Pelegrini 2002; Jeong-Hoon et al., 2001; Seco et al., 2003).

Toxicity tests are bioassays used in pollution control for determining the maximum permitted concentrations of a given chemical agent for the development/survival of certain living organisms (Buratini et al., 2004; Bertolleti et al., 1988; Zagatto et al., 1987). To measure the various effects of pollutants, it is important that toxicity tests are performed using organisms from different trophic levels (Bernard et al., 1997).

Toxic compounds can have two different effects on living organisms: acute toxicity, which is possible to evaluate in the short term upon the death of the organism, and chronic toxicity, whose evaluation takes longer since, in this case, sub-lethal effects must be analyzed (Buratini et al., 2004; Bertolleti et al., 1988; Zagatto et al., 1987).

In this work, acute toxicity was studied in samples of in natura leachate with a view to determining the degree of pollution and contamination of this wastewater.

\section{MATERIALS AND METHODS}

\subsection{Collection Site and Collection Methods}

Leachate was collected at the Limeira Sanitary Landfill, which is located on Tatuibi Road in Limeira, SP. The landfill comprises an area of approximately 50 hectares $(123,55$ acres) of which $190.000 \mathrm{~m}^{2}\left(2.045 .142,98 \mathrm{ft}^{2}\right)$ are meant for the disposal of domestic waste and industrial waste.

This landfill has a system for leachate drainage, which is treated in waste stabilization ponds. These leachate is first treated in an anaerobic pond and then in a facultative pond. Leachate was collected in polyethylene containers, which were stored in a dark room at approximately $4^{\circ} \mathrm{C}$ until sample analysis. This work was carried out from April to June 2005. 


\subsection{Implementation of applied methodologies}

\subsubsection{Determination of acute toxicity in Eruca sativa (arugula)}

A method still under study was used for the toxicological study with seeds of Eruca sativa (arugula). The method consists of placing a paper disk treated with the sample material in a Petri dish and then spreading 50 seeds of arugula on the disk surface. The purpose of the study is to determine the rate of germination of the arugula seeds as well as observe growth inhibition caused by the different concentrations of the sample within a 24- hour period.

\subsubsection{Determination of acute toxicity in Allium cepa (onion)}

A test using Allium cepa as a pattern for environmental monitoring was developed and presented by Fiskesjo (1985). In the case of leachate, the toxicological assays were performed using the method for industrial effluents proposed by Ribeiro (1999). The method consists on the disposal small onions at the chemistry tubes containing the sample in such a way that the onions' radicular systems (roots) are kept in contact with the sample. The purpose of the study is to determine the roots' rate of growth, as well as growth inhibition caused by different concentrations of the sample, all in a five-day period. The onions were kept at room temperature and under natural luminosity. Distilled water was used for both sample dilution and control, with onion bulb diameters ranging from 3.5 to $4.0 \mathrm{~cm}$.

\subsubsection{Determination of acute toxicity in Daphnia similis}

The method specified under NBR 12713 (ABNT, 2003) was used in the toxicological assay with Daphnia similis. It consists of exposing young organisms of the genus Daphnia to various dilutions of the sample within a period of 48 hours.

\subsection{Analyses}

The following parameters were employed to evaluate toxicity of leachate: $\mathrm{pH}$, color, turbidity, conductivity, hardness, nitrogen, total organic carbon (TOC), adsorbable organic halogen (AOX), and metals.

All analyses were performed in accordance with the Standard Methods for the Examination of Water and Wastewater 20th Edition (1998), except for the analysis of TOC, which was in accordance to ISO 8245 (ISO, 1999), and the analysis AOX, which was carried out according to the methodology specified under ISO 9562 (ISO, 1989), using a TOC Euro Glass 1200 device.

\section{RESULTS AND DISCUSSION}

\subsection{Leachate Toxicity}

The studies were aimed to estimate the rate of inhibition of seed germination for arugula and onion (Figure 1) and Daphnias similis (Figures 2 and 3).

In order to estimate leachate toxicity, studies were carried out using solutions of phenol and $\mathrm{Cr}^{+6}$ at an inhibition rate similar to that found in leachate diluted to the $50 \%$ strength. The results indicated similar toxicity to that found for the phenol solution to $1000 \mathrm{mg} . \mathrm{L}^{-1}$ used for arugula and $2000 \mathrm{mg} . \mathrm{L}^{-1}$ for onion. For $\mathrm{Cr}^{+6}$, the concentrations found were $3000 \mathrm{mg} . \mathrm{L}^{-1}$ for arugula and 2000 mg. $\mathrm{L}^{-1}$ for onion (Figure 1 ).

In the case of Daphnias similis, various preliminary tests were also carried out and a specific computer program (Jsper) for the calculation of the EC50 was used (Figures 2 and 3). 
It was possible to observe that the concentration that inhibited $50 \%$ of the organisms in this case was practically the same for all the assays performed during the three months of research.

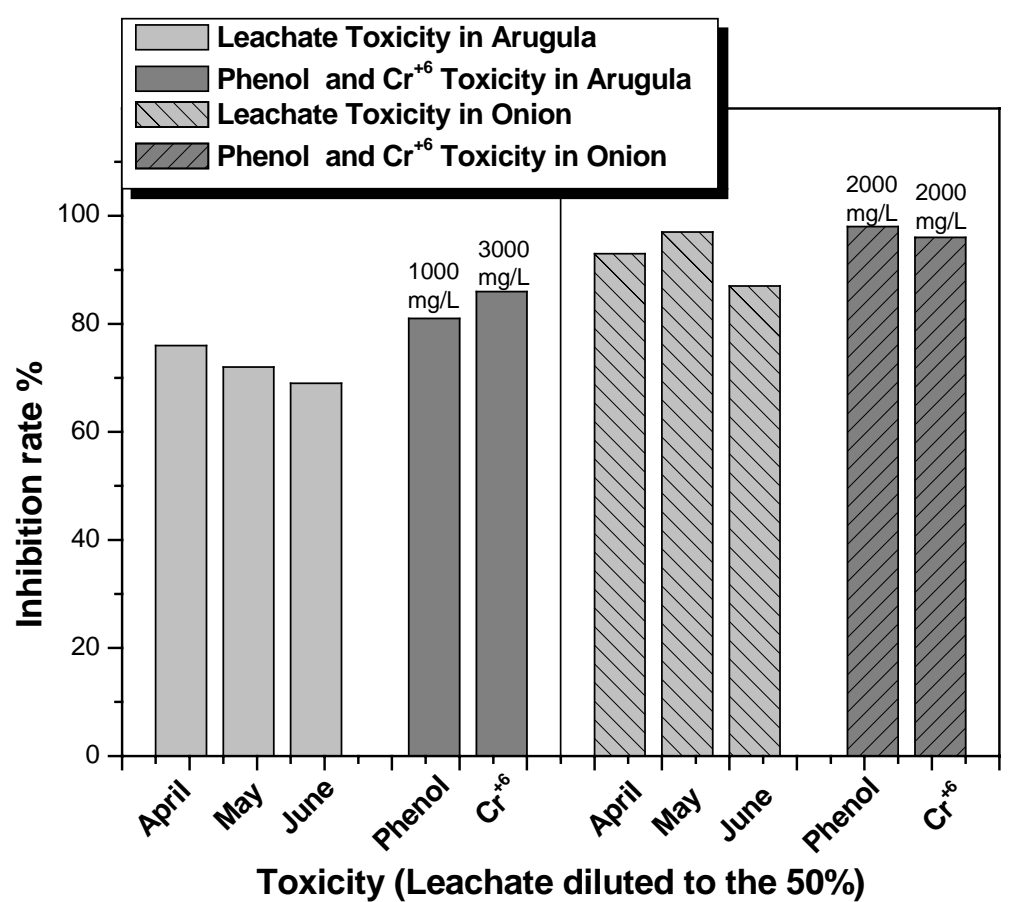

Figure 1. Toxicity assay for arugula and onion, leachate diluted to $50 \%$ strength, as compared to solutions of phenol and $\mathrm{Cr}^{+6}$ (April-June 2005).

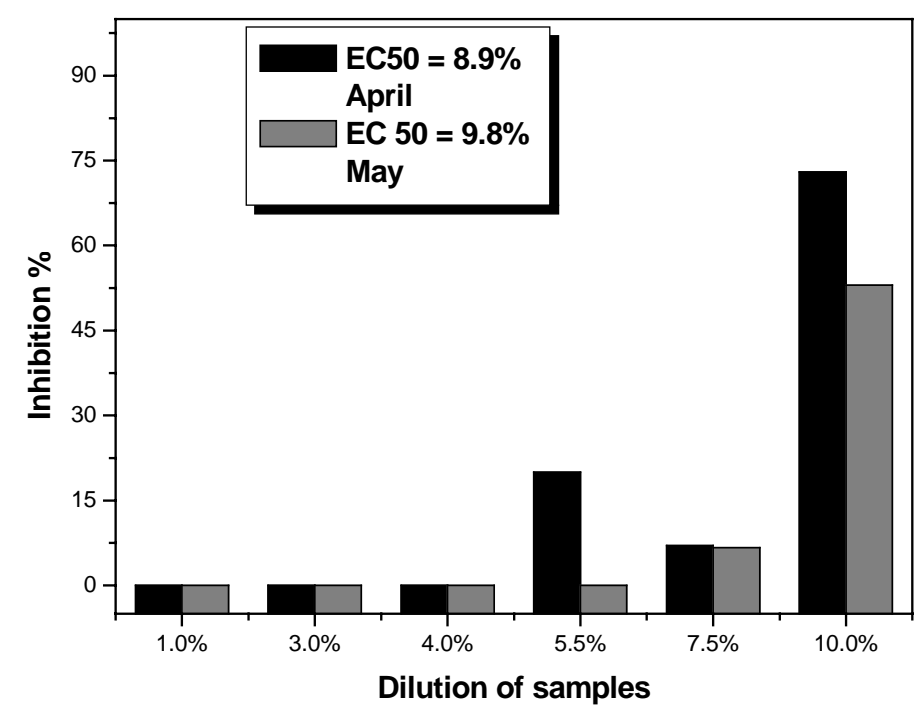

Figure 2. Assay using Daphnia similis- April-May 2005. 


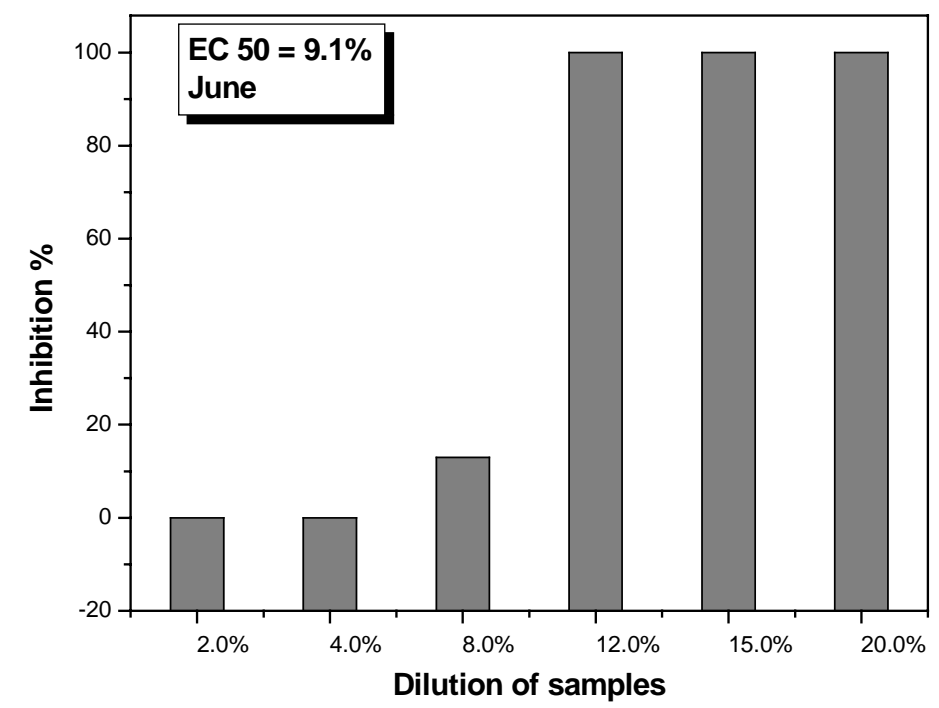

Figure 3. Assay using Daphnia similis- June 2005.

The results of the toxicity assays highlight the high pollution potential of landfill leachate in the city of Limeira. The impacts caused by this type of matrix are usually due to synergetic interaction between the various pollutants. High concentrations of heavy metals, organic matter, nitrogen, and organo-halogenated substances are known to contribute to extreme elevation of toxicity levels in any environment. These classes of compounds are a risk to the ecosystems and public health.

\subsubsection{Metals found in the leachate}

In the leachate samples studied, it was possible to detect the presence of various metals deemed as hazardous to the ecosystems (Table 1). The action of metals within the intracellular compartments can be verified in various manners. A few species are bonded to extra-cellular proteins, others are adsorbed at the level of cell walls, and yet others are diffused through the cell membrane (Araujo et al., 2006).

Table 1. Metal counts readings.

\begin{tabular}{c|c|c|c|c|c|c|c|c|c|c|c}
\hline Metals & Al & Cd & Pb & Cu & Cr & Ni & Zn & K & Na & Fe & Mn \\
\hline $\begin{array}{c}\text { Concentration } \\
\text { mg.L. }^{-1}\end{array}$ & 25.20 & 2.15 & 1.62 & 39.0 & 5.01 & 11.4 & 33.5 & 6.23 & 1825.00 & 54.16 & 17.48 \\
\hline
\end{tabular}

Cadmium, which was found in leachate at levels considerably above the standards for effluent disposal (0.2 mg. $\mathrm{L}^{-1}$ ) (Brasil, 2005) has both a toxic and mutagenic effect on the aquatic biota. The effects on algae and invertebrates are related to an increase in cell volume and inhibition of the flow of calcium. The effects on fishes include inhibition of the various enzyme systems, such as those involved in neurotransmission, trans-epithelial transport, intermediate metabolism, and antioxidant activities. Long-term exposure to non-lethal concentrations has been reported to be connected with skeletal deformations. In the case of vertebrates, the effects are usually related to hypocalcaemia, which results from inhibition of the flow of calcium (Araujo et al., 2006). 
Copper, despite being a micronutrient for both plants and animals, is known to be toxic to the aquatic biota when at high concentrations (maximum permitted level $=1.0 \mathrm{mg} . \mathrm{L}^{-1}$ ) (Brasil, 2005). Although little is known about the primary mechanism of toxicity in plants, it is possible to say that its main effects are photosynthesis inhibition and rupture in vegetative growth (Araujo et al., 2006).

Chrome is known to be a very toxic element, especially in high oxidation number. In leachate, chrome was detected at concentrations 100 times higher than those permitted under disposal standards (Wang et al., 2005).

Lead is potentially carcinogenic and its toxic effects on humans can be detected via symptoms originated in the nervous system, such as muscle tremor, convulsions, paralysis, and coma (Wang et al., 2005).

Nickel and zinc were also found in large amounts, and other metals commonly found in water, such as iron and manganese, were also detected in leachate at concentrations often times exceeding the permitted disposal standards (Wang et al., 2005).

All bivalent metals are known to quickly react with proteins from the amino, imino, and sulphidric groups, and a few of these metals compete with essential elements such as zinc, by dislodging from their binding sites (Araujo et al., 2006; Zoumis et al., 2000; Hirchmann; Forstner, 2000).

Mobilization of heavy metals from the landfill into leachate usually occurs both when hydrated ions are formed and by complexation with organic substrates with low molecular weight (amino acids and sugars), with polymers (fulvic and humic acids), and with colloids of high molecular weight (Zoumis et al., 2000; Hirchmann; Forstner, 2000). These organic compounds are highly colored and high coloration is one way to quantify them, as well as studying color intensity.

A study of leachate coloration was conducted with absorbance rates measured at a $400 \mathrm{~nm}$ wavelength (Table 2). Absorbance rates of 2.46 on average were verified during the study, indicating high concentrations of organic materials capable of complexation with heavy metals. It is also important to stress that high coloration of effluents can strongly interfere with the photosynthetic processes thereby causing alterations in the aquatic biota (Kapdan et al., 2000; Kirby et al., 2000).

Significant amounts of heavy metals can also bond to both inorganic and organic particulate matter, both of which constitute an important means for leachate transportation. Turbidity measurements can also provide an estimate of the amount of particulate matter contained in leachate (Table 2). The specific area of suspended material is large and in the case of leachate, the particles can accommodate large amounts of pollutants. It was possible to observe high turbidity, which was representative of high concentrations of particulate matter. This result can indicate an increased transposition of pollutants into the leachate in addition to the resistance that the excess suspended material opposes to the passage of light. 
Table 2. Average values of the parameters analyzed.

\begin{tabular}{l|c|c}
\hline \multicolumn{1}{c|}{ Parameters } & Mean Values & SD \\
\hline $\mathrm{pH}$ & 8.01 & 0.20 \\
\hline $\begin{array}{l}\text { Color - Abs. } \\
(400 \mathrm{~nm})\end{array}$ & 2.46 & 0.39 \\
\hline $\begin{array}{l}\text { Turbidity } \\
(\mathrm{UT})\end{array}$ & 68.70 & 48.83 \\
\hline $\begin{array}{l}\text { Condutivity } \\
(\mathrm{mS})\end{array}$ & 12.21 & 0.65 \\
\hline $\left.\begin{array}{l}\text { Hardness } \\
\left(\mathrm{mg} . \mathrm{L}^{-1} \mathrm{CaCO}\right.\end{array}\right)$ & 934.00 & 448.50 \\
\hline TOC (mg.L $\left.{ }^{-1}\right)$ & 1116.10 & 550.77 \\
\hline $\begin{array}{l}\mathrm{AOX} \\
\left(\mu g . \mathrm{L}^{-1}\right)\end{array}$ & 690.70 & 370.95 \\
\hline $\mathrm{NH}_{4}{ }^{+}\left(\mathrm{mg} . \mathrm{L}^{-1}\right)$ & 426.00 & 13.65 \\
\hline
\end{tabular}

SD- Standard Deviation.

\subsubsection{Organic Compounds in leachate}

Leachate is a matrix with a high degree of variation in the contents of TOC. That is due to the fact that, in leachate, high concentrations of degrading materials are continuously undergoing consecutive dilutions by both rainwater and recirculation of leachate itself. It was observed TOC values that were higher than 1000.00 mg.L ${ }^{-1}$, which characterizes wastewater with a high content of organic matter (Table 2).

In landfills over 10 years of age but still in operation, as it is the case, it is possible to find a countless number of organic compounds present in leachate which are derived from both short-term and medium-term decomposition as well as non-biodegradabable substances, the latter accounting for the strongest impact on the environment.

The structure of organic compounds is a determining factor in toxicity analyses. Organonitrogenated substances for instance have a highly polluting potential, especially due to its metabolites, among which is ammonia. High concentrations of ammoniacal nitrogen were detected in leachate (Table 2). Concentrations exceeding $400.00 \mathrm{mg} . \mathrm{L}^{-1}$ could be observed throughout the monitoring period.

The organo-halogenated compounds determined in the AOX parameter analysis are commonly defined as the fraction corresponding to the concentration containing adsorbable organically bound halogens. This class of substances is represented by highly toxical and mutagenic chemical species such as the organochlorides, the halogenated agrochemicals, the CFCs, etc. In leachate, high concentrations of AOX were detected $(900 \mu \mathrm{g} / \mathrm{L})$, which can cause great concern since they can persist in the aquatic environments/habitats and cause bioaccumulation (Table 2).

\subsubsection{Toxicity and Bioavailability}

The effects of toxicity of organic compounds on the aquatic organisms can range from mortality to hepatoxicity, immunotoxicity, carcinogenicity, and metabolic alterations that can lead to a decrease in the rates of reproduction, predation, and decomposition (Araujo et al., 2006; Dave; Nilsson, 2005). 
Organo-halogenated and organo-nitrogenated compounds as well as heavy metals remain highly toxical, with a high potential of bioavailability, especially when they are water-soluble. The $\mathrm{pH}$ values and the ion exchange capacity are important factors that interfere with the relation between adsorption and deadsorption in compounds as it may render the specie either more or less available.

$\mathrm{pH}$ values of leachate were found to be slightly alkaline. This is due to the methanogenic phase of solid waste degradation at the landfill and can contribute to reduce toxicity levels since these alkaline values can favor the precipitation of metals by making them less bioavailable (Table 2).

The high values of conductivity were found for wastewaters and may influence the death of test organisms due to the excess concentration of salts and an increase in the ionic exchange ability of the compounds (Table 2). This fact is deemed unfavorable as it causes the toxicity of leachate to increase.

Water from the studied leachate is classified as hard water (carbonate concentration high) (Table 2). Studies have suggested that very hard water is capable of reducing toxicity of a few metals such as cadmium, copper, and lead. That occurs when this water complexes with these metals, thereby making them insoluble and causing bioaccumulation to decrease (Borgmann et al., 2005; Borgmann et al., 2004; Markich et al., 2005). In this case, hardness can be deemed to favor toxicity reduction.

\section{CONCLUSIONS}

This work corroborates the high toxicity indexes found in the leachate samples studied. Ecotoxicological evaluation of wastewater from such a source is fundamental for assessing the risks posed to both the environment and public health in municipalities where waste is not adequately treated.

Characterization of physico-chemical parameters of leachate such as $\mathrm{pH}$, turbidity, and conductivity, as well as chemical parameters such as hardness, TOC, AOX, and the presence of nitrogen, biological parameters such as toxicity, and potentially available metals such as $\mathrm{Cd}, \mathrm{Cu}, \mathrm{Cr}, \mathrm{Pb}, \mathrm{Zn}, \mathrm{Ni}, \mathrm{Fe}, \mathrm{Mn}$ were of fundamental importance in determining the contaminants present in this effluent and evaluating the potential impact of landfill leachate.

\section{ACKNOWLEDGMENTS}

The authors would like to acknowledge financial support from CNPq.

\section{REFERENCES}

ARAUJO, R. P. A.; BOTTA-PASCHOAL, C. M. R.; SILVERIO, P. F.; ALMEIDA, F. V.; RODRIGUESS, P. E.; UMBEZEIRO, G. A. et al. Application of toxicity identification evaluation to sediment in a highly contaminated water reservoir in southeastern Brazil. Environmental Toxicology and Chemistry, Brussels, v. 25, n. 02, p. 581-588, 2006.

ASSOCIAÇÃO BRASILEIRA DE NORMAS TÉCNICAS. NBR 12713: Ecotoxicologia aquática: toxicidade aguda: método de ensaio com Daphnia spp (Cladocera, Crustacea). Rio de Janeiro: ABNT, 2003.

BERNARD, C.; COLIN, J. R.; ANNE, L. D. D. Estimation of the hazard of landfills through toxicity testing of leachates. Chemosphere, [S.l.], v. 35, n. 11, p. 2783-2796, 1997. 
BERTAZZOLI, R.; PELEGRINI, R. Photoeletrochemical discoloration and degradation of organic pollutants in aqueous solutions. Química Nova, São Paulo, v. 25, n. 03, p. 477482, 2002.

BERTOLLETI, E.; ARAÚJO, R. P. A.; ZAGATTO, P. A.; CHERARDIGOLDSTEIN, E. Toxicity evaluation of paper-mill effluents. Water Science and Technology, London, v. 20, n. 02, p. 191-198, 1988.

BORGMANN, U.; NORWOOD, W. P.; DIXON, D. G. Re-evaluation of metal bioaccumulation and chronic toxicity in Hyalella azteca using saturation curves and the biotic ligand model. Environmental Pollution v. 131, n. 03, p. 469-484, 2004.

BORGMANN, U.; COUILLARD, Y.; DOYLE, P.; DIXON D. G. Toxicity of sixty-three metals and metalloids to Hyalella azteca at two levels of water hardness. Environmental Toxicology and Chemistry, Brussels, v. 24, n. 03, p. 641-652, 2005.

BURATINI, S. V.; BERTOLLETI, E.; ZAGATTO, P. A. Evaluation of daphnia similis as a test species in ecotoxicological assays. Bulletin of Environmental Contamination and Toxicology, v. 73, n. 05, p. 878-882, 2004.

BRASIL. Ministério do Meio Ambiente. Conselho Nacional do Meio Ambiente. Resolução CONAMA 357. 2005. Disponível em: < http://www.mma.gov.br/port/conama>. Acesso em: 17 outubro 2007.

DAVE, G.; NILSSON, E. Increased reproductive toxicity of landfill leachate after degradation was caused by nitrite. Aquatic Toxicology v. 73, n. 01, p.11-30, 2005.

FISKESJO G. The Allium test as a standard in environmental monitoring. Hereditas, v. 102, p. 99-112, 1985.

HIRCHMANN, G.; FORSTNER, U. Long-term assessment for the leachate release of heavy metals from municipal solid waste incineration bottom ash monofills. Acta Hydrochimica Hydrobiologica, v. 28, n. 05, p. 262-271, 2000.

INTERNATIONAL STANDARD ORGANIZATION. ISO 9562: water quality: determination of adsorbable organic halogens (AOX). Geneva: ISO, 1989.

INTERNATIONAL STANDARD ORGANIZATION. ISO 8245: guidelines for the determination of total organic carbon (TOC) and dissolved organic carbon (DOC). Geneva: ISO, 1999.

ISIDORI, M.; LAVORGNA, M.; NARDELLI, A.; PARELLA, A. Toxicity identification evaluation of leachates from municipal solid waste landfills: a multispecies approach. Chemosphere, v. 52, n. 01, p. 85-94, 2003.

JEONG-HOON, I.M.; HAE-JIN, W.; MYUNG-WON, C.; KI-BACK, H.; CHANG-WON, K. Simultaneous organic and nitrogen removal from municipal landfill leachate using an anaerobic-aerobic system. Water Research, v. 35, n. 10, p. 2043-2410, 2001.

KAPDAN, I. K.; KARGI, F.; MCMULLAN, G.; MARCHANT, R. Biological decolorization of textile dyestuff by Coriolus versicolor in a packed column reactor. Environmental Technology, v. 21, n. 02, p. 231-236, 2000. 
KIRBY, N.; MARCHANT, R.; MSMULLAN, G. Decolourisation of synthetic textile dyes by Phlebia tremellosa. Fems Microbiology Letters, v. 188, n. 01, p. 93-96, 2000.

MARKICH, S. J.; BATLEY, G. E.; STAUBER, J. L.; ROGERS, N. J.; APTE, S. C.; HYNE, R.V. et al. Hardness corrections for copper are inappropriate for protecting sensitive freshwater biota. Chemosphere v. 60, n. 01, p. 1-8, 2005.

RIBEIRO, I. A. Teste de raízes de cebola para avaliação de toxicidade de efluentes industriais. Engenharia Sanitária Ambiental, v. 4, n. 03, p. 108-112, 1999.

SECO, J. I.; FERNÁNDEZ-PEREIRA, C.; VALE, J. A study of the leachate toxicity of metal-containing solid wastes using Daphnia magna. Ecotoxicological Environmental Safety, v. 56, n. 03, p. 339-350, 2003.

ZAGATTO, P. A.; CHERARDIGOLDSTEIN, E.; BERTOLLETI, E.; LOMBARDI. C.C.; MARTINS, M. H. R. B.; RAMOS, M. L. L. C. Bioassays with aquatic organismstoxicity of water in sediment from Cubatão river basin. Water Science and Technology, London, v. 19, n. 11, p. 95-106, 1987.

ZOUMIS, T.; CALMANO, W.; FORSTNER, U. Demobilization of heavy metals from mine waters. Acta Hydrochimica Hydrobiologica, v. 28, n. 04, p. 212-218, 2000.

WANG, X.; SATO T.; BAOSHAN, X.; TAO, S. Health risks of heavy metals to the general public in Tianjin, China via consumption of vegetables and fish. Science Total Environmental, v. 350, p. 28-37, 2005. 


\begin{tabular}{|c|} 
ISSN = 1980-993X - doi:10.4136/1980-993X \\
www.agro.unitau.br/ambi-agua \\
E-mail: ambi-agua@agro.unitau.br \\
Tel.: (12) 3625-4116
\end{tabular}

\title{
Avaliação da interação de Zinco, Alumínio, Cobre e Manganês em Chromobacterium violaceum \\ (doi:10.4136/ambi-agua.32)
}

\author{
Tânia Cristina Sumita ${ }^{1}$; Rogério Santos Pereira ${ }^{1}$; Messias Borges Silva ${ }^{2}$; Luis Carlos \\ Laureano da Rosa ${ }^{3}$; Mariko Ueno ${ }^{4}$
}

\author{
${ }^{1}$ Mestrando Escola de Engenharia Lorena - EEL - Universidade de São Paulo \\ E-mail: sumitatc@terra.com.br; pereira_rs2000@yahoo.com.br \\ ${ }^{2}$ Escola de Engenharia Lorena - EEL - Universidade de São Paulo \\ E-mail: messias@dequi.eel.usp.br \\ ${ }^{3}$ Núcleo de Pesquisa Econômico-Sociais - Universidade de Taubaté \\ E-mail: laureano@unitau.br \\ ${ }^{4}$ Instituto Básico de Biociências - Universidade de Taubaté \\ E-mail: mariueno@unitau.br
}

\section{RESUMO}

Os metais traços liberados por atividades extrativistas, mineralógicas, industriais, agroindustriais e pelos resíduos urbanos acumulam-se no meio ambiente, afetando o equilíbrio dinâmico dos ecossistemas onde estão presentes, gerando não apenas um problema ambiental, mas também econômico. Com foco no potencial biotecnológico de Chromobacterium violaceum, o objetivo deste trabalho foi avaliar a resistência dessa cepa a quatro sais metálicos: sulfato de alumínio, sulfato de cobre, sulfato de manganês e sulfato de zinco, bem como um possível efeito de interação de $2^{\mathrm{a}}$ ordem, utilizando um planejamento fatorial completo $2^{4}$. Para todos os sais estudados, usou-se a concentração de $100 \mathrm{mg} / \mathrm{L}$ ou a ausência do sal. Em uma microplaca de cultura com 96 orifícios, foram realizados os 16 experimentos, em duplicata. Uma suspensão do microrganismo foi preparada como inóculo e diluída em Caldo Nutriente para ser adicionada aos orifícios. Após 24 horas de incubação a $37^{\circ} \mathrm{C}$, foi realizada a leitura da absorbância a 410nm em leitora de microplacas Versamax. Os resultados mostraram alta capacidade de adaptação de $C$. violaceum aos sais estudados. A análise dos resultados pelo teste $t$ de Student mostrou que o Manganês foi o único metal que não teve efeito significativo sobre o crescimento de C. violaceum, enquanto o Zinco foi o mais ativo, sendo observadas interações positivas envolvendo a presença do Zinco; a interação entre Alumínio e Cobre não foi relevante.

Palavras-chave: Chromobacterium violaceum; sais metálicos; interação.

\section{Evaluation of interaction of Zinc, Aluminum, Copper and Manganese on Chromobacterium violaceum}

\section{ABSTRACT}

The accumulation of metallic salts in the environment resulted from the explotation, mineralogy, industrial, and agro-industrial activities and urban residues affect the dynamic balance of ecosystems, generating environmental and economic problems. The aim of this study was to evaluate the interaction of Chromobacterium violaceum with four metallic salts: aluminum sulphate, copper sulphate, manganese sulphate and zinc sulphate at concentration of $100 \mathrm{mg} / \mathrm{L}$ or the absence of them, as well as a possible $2^{\text {nd }}$ order interaction effect, using a complete $2^{4}$ factorial design. The 16 experimental tests were carried out in microplate culture. Suspension of microorganism was prepared in Nutrient Broth and added to the orifices. After 
incubation at $37^{\circ} \mathrm{C}$ during 24 hours, the absorbance was carried out using a $410 \mathrm{~nm}$ in Versamax reader. The results showed remarkable bacterial adaptability. Student $t$ test analysis showed that manganese was the only metal that did not have significant effect on the population growth of $C$. violaceum while zinc was the most influent. Positive interactions involving zinc was observed, interaction between aluminum and copper was not relevant.

Keywords: Chromobacterium violaceum; metallic salts; interaction.

\section{INTRODUÇÃO}

O estudo da resistência dos microrganismos aos metais é importante, não somente para a compreensão da homeostase do metal, mas também para a utilização desses microrganismos em biorremediação.

Os organismos vivos estão constantemente expostos aos metais pesados na natureza, freqüentemente presentes na sua forma ionizada; esses íons exercem efeitos tóxicos aos microrganismos, portanto, essa exposição seleciona e mantém as cepas capazes de tolerar seus efeitos danosos. Mecanismos de resistência eficientes têm sido identificados em bactérias e fungos.

O estudo das interações entre microrganismos e metais pode auxiliar no conhecimento das relações tóxicas de metais com organismos superiores como plantas e animais. Alguns sistemas microbianos de tolerância ao metal poderiam ser utilizados em processos biotecnológicos, tais como a biorremediação de ambientes poluídos com metais (Cervantes et al., 2006).

Chromobacterium violaceum é um bacilo Gram negativo, anaeróbio facultativo habitante de ecosistemas tropicais e sub-tropicais principalmente em água e solo, capaz de sobreviver em condições ambientais adversas. Atualmente a seqüência genômica de $C$. violaceum ATCC 12472 está disponível e possui considerável potencial biotecnológico, como detoxificação ambiental e também para utilização na medicina e agricultura (Carepo et al., 2004 e Duran; Menck, 2001).

Chromobacterium violaceum é um microrganismo de vida livre, normalmente exposto a condições ambientais variadas, possui metabolismo energético versátil (Lima-Bittencourt et al., 2007). É capaz de utilizar varias fontes de energia por meio de suas enzimas oxidases e redutases, o que propicia o seu desenvolvimento em ambientes aeróbios e anaeróbios. Em condições aeróbias é capaz de crescer em meio mínimo suplementado com açúcares simples como glucose, frutose, galactose e ribose, utiliza a via Embden-Meyerhoff e ácidos tricarboxílicos e também o ciclo glioxilato. Em condições anaeróbias, C. violaceum metaboliza glicose com produção de ácido acético e fórmico e também utiliza aminoácidos e lipídios como fonte de energia (Creczynski-Pasa; Antonio, 2004).

Muitas proteínas relacionadas à tolerância contra substâncias antimicrobianas, metais pesados, temperatura e presença de ácidos promovem a sobrevivência em condições adversas e enzimas capazes de detoxificar espécies reativas de oxigênio também foram detectadas em C. violaceum. Esses fatores poderiam explicar a alta competitividade e habilidade em sobreviver sob diferentes tipos de estresse ambiental (Hungria et al., 2004).

O complexo conjunto de substâncias transportadoras em $C$. violaceum, seguramente é um importante fator que permite que esse microrganismo seja uma bactéria dominante em uma variedade de ecossistemas de regiões tropical e sub-tropical. Sob o ponto de vista biotecnológico, o achado mais importante são os transportadores de metais pesados, os quais podem conduzir à exploração de $C$. violaceum para biorremediação (Grangeiro et al., 2004). 
Compondo a matéria inorgânica do planeta os metais encontram-se dispersos na natureza. Dessa forma, eles estão por toda parte e ativamente sendo liberados pelos resíduos urbanos, agroindustriais (Azevedo et al., 2006), industriais (Teitzel; Parset, 2003) e por atividades de mineração (Pereira; Souza, 2005; Gremion et al., 2004; Castro-Silva et al., 2003).

Em alguns ecossistemas, os metais traços podem ser absorvidos facilmente por frações orgânicas e inorgânicas, entretanto, essa incorporação depende da concentração desses metais bem como as características dos componentes do sistema tanto biótico como abiótico. É evidente a bioacumulação de metais traços por peixes e moluscos filtradores, mesmo quando esses contaminantes se encontram em níveis quase não detectáveis, tornando esses organismos impróprios para o consumo humano (Machado et al., 2002; Lee et al., 2000).

Vários metais traços podem ser responsáveis por agravos às doenças neurológicas, sendo o alumínio um metal estudado com relação ao mal de Alzheimer e escleroses, do mesmo modo existe uma discussão sobre a influência do manganês, ferro e cobre sobre o mal de Parkinson (Brown et al., 2005). Entretanto, doses pequenas de certos metais parecem ter algum potencial terapêutico para humanos (Lowry et al., 1979) e animais (Adogwa et al., 2005) que ainda é discutível (Mandinov et al., 2003).

Contudo, Shomron et al. (2002) demonstraram que a adição de zinco inibe o segundo passo do splicing do cromossomo em leveduras (formação do RNA mensageiro), podendo haver correlação homóloga em humanos.

Traços de metais se encontram interagindo com biofilmes, sendo de grande interesse no aumento da aderência dessas bactérias ao substrato, podendo assim controlar sua distribuição. Assim, a avaliação tóxica desses metais pode esclarecer a influência sobre a atividade metabólica na engenharia de bioreatores bem como em aplicações médicas (Hu et al., 2005).

De forma inegável, os microrganismos têm co-existido com os metais na História da Terra, tal fato é observado quando metais divalentes ou de transição estão presentes no sítio ativo de muitas enzimas e, até mesmo sendo chave de reações bioquímicas. Entretanto, de ponto de vista fisiológico é possível observar que altas concentrações de metais ( $\mathrm{Zn}, \mathrm{Cu}, \mathrm{Mn}$, $\mathrm{Fe}, \mathrm{Co}, \mathrm{Ni}$ e Mo) passam a se tornar tóxicas para algumas espécies de microrganismos (Valls; Lorenzo, 2002).

Castro-Silva et al. (2003) relatam que subprodutos de extração mineralógica de carvão acidificam as águas que, por sua vez, aceleram o processo de solubilização de metais traços, tornando esses ambientes seletivos para vários microrganismos.

Pereira e Souza (2005) demonstram que em atividades extrativistas minerais é possível, dependendo do tipo da rocha da região, ter um valor médio de presença de vários metais na rede de drenagem principal, onde foi destacada a presença de 3,80 - 4,35\% de $\mathrm{Al}$; 39,0 40,25 mg/Kg de Cu; 1134 - 1205 mg/Kg de Mn e 93 - 79,65 mg/Kg de Zn.

Tendo em vista que as tecnologias convencionais de tratamento, tais como: precipitação, oxidação ou redução, filtração, tratamento eletroquímico, tecnologia de membranas e recuperação evaporativas, são pouco eficientes ou extremamente caras para operacionalização (Franchi; Sígolo, 2004) e que há capacidade adaptativa entre os bacilos Gram-negativos de resistência a certas concentrações de metais traços (Valls; Lorenzo, 2002) torna a biorremedição uma técnica de grande potencial para ambientes contaminados com metais (Nascimento; Chartone-Souza, 2003).

Neste trabalho foi analisada a interação de C. violaceum recém-isolada de poço da região rural de Pindamonhangaba, SP com metais traços o que adiciona um caráter de aplicação prática desta pesquisa. 


\section{MATERIAL E MÉTODOS}

\subsection{Metais, meios e microrganismo utilizados}

Foi utilizada a cepa de Chromobacterium violaceum recém-isolada de água de poço no interior do estado de São Paulo, Brasil. A cepa foi identificada utilizando o método Api20E (BioMerieux).

Os sais estudados foram: sulfato de zinco, sulfato de alumínio, sulfato de cobre e sulfato de manganês (Merck). Para se obter o meio Caldo Nutriente (Difco) adicionado desses metais, prepararam-se soluções concentradas $(1600 \mathrm{mg} / \mathrm{L})$ de sais contendo esses íons metálicos, que foram adicionadas ao meio de cultura segundo um planejamento fatorial completo em dois níveis de concentração.

\subsection{Planejamento Fatorial Completo $2^{4}$}

Por meio desse modelo foi possível observar os efeitos principais e suas interações utilizando-se 16 experimentos diferentes entre si, de acordo com a Tabela 1.

Tabela 1. Combinação dos 16 tratamentos experimentais (Fatorial $2^{4}$ ).

\begin{tabular}{ccccc}
\hline Experimento & $\begin{array}{c}\text { Sulfato de } \\
\text { Zinco } \\
(\mathbf{m g} / \mathbf{L})\end{array}$ & $\begin{array}{c}\text { Sulfato de } \\
\text { Alumínio } \\
(\mathbf{m g} / \mathbf{L})\end{array}$ & $\begin{array}{c}\text { Sulfato de Cobre } \\
(\mathbf{m g} / \mathbf{L})\end{array}$ & $\begin{array}{c}\text { Sulfato de } \\
\text { Manganês } \\
(\mathbf{m g} / \mathbf{L})\end{array}$ \\
\hline 01 & 0 & 0 & 0 & 0 \\
02 & 100 & 0 & 0 & 0 \\
03 & 0 & 100 & 0 & 0 \\
04 & 100 & 100 & 0 & 0 \\
05 & 0 & 0 & 100 & 0 \\
06 & 100 & 0 & 100 & 0 \\
07 & 0 & 100 & 100 & 0 \\
08 & 100 & 100 & 100 & 100 \\
09 & 0 & 0 & 0 & 100 \\
10 & 100 & 0 & 0 & 100 \\
11 & 0 & 100 & 0 & 100 \\
12 & 100 & 100 & 0 & 100 \\
13 & 0 & 0 & 100 & 100 \\
14 & 100 & 0 & 100 & 100 \\
15 & 0 & 100 & 100 & 00 \\
16 & 100 & 100 & 100 & \\
\hline
\end{tabular}

\subsection{Preparo do inóculo}

A cepa de C. violaceum foi reativada em Caldo Nutriente (Difco) durante 24 horas a $37^{\circ} \mathrm{C}$ em ambiente aeróbio e, em seguida, foi repicada em Agar Sangue (Difco) para a sincronização celular e incubada novamente por 24 horas a $37^{\circ} \mathrm{C}$ em ambiente aeróbio. A partir desse crescimento microbiano foi preparada uma suspensão celular em solução fisiológica com turbidez equivalente ao tubo número 1 da escala de MacFarland, correspondendo a, aproximadamente, $3 \times 10^{8} \mathrm{UFC} / \mathrm{mL}$. Essa suspensão foi diluída até $10^{-6} \mathrm{e}$ as três últimas diluições decimais foram semeadas em superfície com inóculo de $0,1 \mathrm{~mL}$ com alça de Drigalski, em duplicata. As placas que continham de 30 a 300 colônias foram contadas para estimar a proporção de células presente na suspensão.

A suspensão celular foi diluída a $10^{-2}$ em Caldo Nutriente e inoculado nos orifícios da placa em volumes de $0,1 \mathrm{~mL}$, exceto nos orifícios destinados à leitura do branco, nos quais foram colocadas $0,1 \mathrm{~mL}$ de Caldo Nutriente. 


\subsection{Preparo dos experimentos}

Foram preparados em tubos de ensaio esterilizados numerados de 1 a 16 de acordo com a matriz experimental. Em cada tubo foi adicionado $0,25 \mathrm{~mL}$ de solução concentrada de sulfato metálico $(1600 \mathrm{mg} / \mathrm{L})$ e o volume foi completado a $1 \mathrm{~mL}$ com água destilada estéril. Em seguida, foi adicionado $1 \mathrm{~mL}$ de Caldo Nutriente preparado com concentração dupla em todos os tubos, obtendo-se o meio com 16 combinações diferentes de metais.

Numa placa de cultura de células com tampa e estéril, foram distribuídos 0,1mL dos experimentos de modo a se obter duplicatas de cada condição e 16 leituras de branco.

Posteriormente, o Caldo Nutriente contendo o inóculo foi adicionado $(0,1 \mathrm{~mL})$ a todos os experimentos e o mesmo caldo estéril foi adicionado aos brancos, completando volume de 0,2mL em cada orifício.

Após 24 horas de incubação a $37^{\circ} \mathrm{C}$ em ambiente aeróbio, foi realizada a leitura da absorbância a 410nm de cada orifício da placa em uma leitora de microplacas Versamax (Molecular Devices).

Os resultados obtidos, em absorbância, foram comparados entre os grupos estudados por meio do teste $t$ de Student (alfa $=5 \%)$.

\section{RESULTADOS}

A contagem de UFC/mL proveniente da suspensão preparada mostrou que a suspensão continha $2,8 \times 10^{8} \mathrm{UFC} / \mathrm{mL}$, confirmando o número de células desejado como inóculo de 2,8 $\mathrm{x} 10^{6} \mathrm{UFC} / \mathrm{mL}$, e cada orifício recebeu uma carga microbiana de aproximadamente $2,8 \times 10^{5}$ $\mathrm{UFC} / \mathrm{mL}$, que seria suficiente para iniciar o crescimento microbiano.

Visando obter observação de reprodutibilidade e garantindo maior confiabilidade dos resultados, os experimentos foram realizados em duplicata para todos os pontos estudados, seguindo o planejamento fatorial completo $2^{4}$, como apresentado na Tabela 2 . A microplaca utilizada para os experimentos apresentou tonalidades diferentes de violeta em cada condição experimental, o que indica a diferença na intensidade do crescimento microbiano, tendo em vista a coloração natural de C. violaceum. 
Tabela 2. Valores de absorbância obtidos em 24h de incubação no espectro de $410 \mathrm{~nm}$.

\begin{tabular}{crrrccc}
\hline $\mathbf{N}^{\mathbf{0}}$ Ex. & \multicolumn{3}{c}{ Fatores } & \multicolumn{2}{c}{ Respostas } \\
\hline & Zn & Al & Cu & Mn & Réplica 1 & Réplica 2 \\
\hline 1 & -1 & -1 & -1 & -1 & 0,8477 & 0,9776 \\
2 & 1 & -1 & -1 & -1 & 0,0254 & 0,0098 \\
3 & -1 & 1 & -1 & -1 & 0,7299 & 0,7591 \\
4 & 1 & 1 & -1 & -1 & 0,2864 & 0,0772 \\
5 & -1 & -1 & 1 & -1 & 0,4565 & 0,4410 \\
6 & 1 & -1 & 1 & -1 & 0,0511 & 0,0268 \\
7 & -1 & 1 & 1 & -1 & 0,3890 & 0,3573 \\
8 & 1 & 1 & 1 & -1 & 0,0961 & 0,0962 \\
9 & -1 & -1 & -1 & 1 & 0,5981 & 0,6010 \\
10 & 1 & -1 & -1 & 1 & 0,0472 & 0,0278 \\
11 & -1 & 1 & -1 & 1 & 0,6405 & 0,6342 \\
12 & 1 & 1 & -1 & 1 & 0,2660 & 0,0928 \\
13 & -1 & -1 & 1 & 1 & 0,5254 & 0,5167 \\
14 & 1 & -1 & 1 & 1 & 0,1266 & 0,0848 \\
15 & -1 & 1 & 1 & 1 & 0,5703 & 0,5744 \\
16 & 1 & 1 & 1 & 1 & 0,2437 & 0,1359 \\
\hline
\end{tabular}

A média global foi de 0,354 com um desvio padrão bem pequeno de 0,007. A Tabela 3 apresenta o valor da média ( $\overline{\mathrm{X}})$ e do desvio padrão (S) para cada experimento.

Tabela 3. Valores da média e desvio padrão de cada experimento.

\begin{tabular}{ccc}
\hline Experimento & $(\overline{\mathrm{X}})$ & $\mathbf{S}$ \\
\hline 1 & 0,913 & 0,0920 \\
2 & 0,018 & 0,0100 \\
3 & 0,745 & 0,0210 \\
4 & 0,182 & 0,1480 \\
5 & 0,449 & 0,0110 \\
6 & 0,039 & 0,0170 \\
7 & 0,373 & 0,0220 \\
8 & 0,096 & 0,0001 \\
9 & 0,600 & 0,0020 \\
10 & 0,038 & 0,0140 \\
11 & 0,637 & 0,0040 \\
12 & 0,179 & 0,1220 \\
13 & 0,521 & 0,0060 \\
14 & 0,106 & 0,0300 \\
15 & 0,572 & 0,0030 \\
16 & 0,190 & 0,0760 \\
\hline
\end{tabular}

Para se conhecer o nível de interferência de cada fator, foi calculado o efeito para cada fator e interações de $2^{\circ}$ ordem. Os resultados estão representados nas Tabelas 4 e 5, respectivamente. 
Tabela 4. Cálculo do efeito para cada fator.

\begin{tabular}{cccc}
\hline Zn & Al & Cu & Mn \\
\hline$-0,49531$ & 0,036594 & $-0,12056$ & 0,00364375 \\
\hline
\end{tabular}

Tabela 5. Cálculo do efeito de interação de $2^{\underline{a}}$ ordem.

\begin{tabular}{llllll}
\hline Zn-Al & Zn-Cu & Zn-Mn & Al-Cu & Al-Mn & Cu-Mn \\
\hline 0.075256 & 0.124131 & 0.040831 & 0.00734 & 0.042181 & 0.104331 \\
\hline
\end{tabular}

Os valores $t$ de Student para cada fator e interação foram obtidos, dividindo-se o módulo efeito pelo erro, denominado de $t$, calculado apresentado na Tabela 6, bem como seus pvalores.

Tabela 6. Valores de $t$ calculado.

\begin{tabular}{crc}
\hline Fatores & $\boldsymbol{t}$ calculado & p-valor \\
\hline $\mathrm{Zn}$ & 69,60865 & 0,0000 \\
$\mathrm{Al}$ & 5,14276 & 0,0001 \\
$\mathrm{Cu}$ & 16,94256 & 0,0000 \\
$\mathrm{Mn}$ & 0,51208 & 0,6161 \\
$\mathrm{Zn}-\mathrm{Al}$ & 10,57626 & 0,0000 \\
$\mathrm{Zn}-\mathrm{Cu}$ & 17,44498 & 0,0000 \\
$\mathrm{Zn}-\mathrm{Mn}$ & 5,73829 & 0,0000 \\
$\mathrm{Al}-\mathrm{Cu}$ & 1,03207 & 0,3184 \\
$\mathrm{Al}-\mathrm{Mn}$ & 5,92801 & 0,0000 \\
$\mathrm{Cu}-\mathrm{Mn}$ & 14,66236 & 0,0000 \\
\hline
\end{tabular}

Considerando o grau de liberdade de 15 e o nível de significância de $5 \%(\alpha=0,05)$ é possível observar que exceto o efeito do $\mathrm{Mn}(\mathrm{p}=0,6161)$ e a interação $\mathrm{Al}-\mathrm{Cu}(\mathrm{p}=0,3184)$ todas as outras interações apresentam efeitos significativos $(\mathrm{p}>0,05)$.

\section{DISCUSSÃO}

As concentrações utilizadas nos experimentos estão acima dos índices recomendados pela CETESB (São Paulo, 2006) para qualquer dos metais utilizados, no entanto, ainda menores do que os índices mais altos de poluição indicados por Pereira e Souza (2005), mesmo assim, essas concentrações se mostraram significativas no efeito sobre o crescimento microbiano de C. violaceum.

Vale a pena destacar o efeito causado pela presença de sulfato de zinco, no experimento de número 2, em que foi observado o menor valor de absorbância, podendo ser considerado o metal que mais afetou o crescimento do microrganismo. Porém, nos experimentos em que esse mesmo metal foi adicionado de outros, os valores foram significativamente maiores, indicando que há interação entre os efeitos dos metais. O modelo proposto poderia ser utilizado em uma situação de tratamento de um efluente em que haja zinco, por exemplo, além de uma grande carga orgânica, para viabilizar uma fermentação microbiana pela suplementação do meio com outros íons metálicos, para que, posteriormente, fosse realizado o tratamento químico para retirar o metal pesado.

Os mecanismos que envolvem a resistência aos metais traços, bem como suas interações necessitam de esclarecimento. Nascimento e Chartone-Souza (2003) sugerem que haja relação entre a resistência desses microrganismos aos metais traços e aos antibióticos. 
Como microrganismo de vida livre, a C. violaceum está exposta às condições ambientais variadas. Essas variações requerem grande adaptabilidade e sistemas de proteção. Esses fatores poderiam explicar a alta competitividade e habilidade em sobreviver sob diferentes tipos de estresse ambiental (Hungria et al., 2004), tal como a presença de metais no ambiente.

Há interação entre os diferentes metais testados e interferência no crescimento de $C$. violaceum e o zinco foi o metal que mais influenciou o crescimento de $C$. violaceum Para que o microrganismo consiga sobreviver em ambiente na presença de metais como ocorreu neste estudo é necessário que este possua enzimas e transportadores de metais pesados (Grangeiro et al., 2004).

\section{CONCLUSÃO}

Estudos mais detalhados precisam ser realizados, entretanto, este trabalho indica que $C$. violaceum é capaz de crescer em ambiente com altas concentrações dos metais traços testados, portanto, sob o ponto de vista biotecnológico, essa bactéria possui potencial para ser utilizada para biorremediação.

\section{REFERÊNCIAS}

ADOGWA, A.; MUTANI, A.; RAMANAN, A.; EZEOKOLI, C. The effect of gastrointestinal parasitism on blood copper and hemoglobin levels in sheep. Can. Vet. J., v. 46, p. 1017-21, 2005.

AZEVEDO J; SILVA FILHO, EV; DAMASCENO, RN; LIMA, MW. Metais pesados nos compostos de lixo urbano da usina de Irajá, Município do Rio de Janeiro. Rede jornal do meio ambiente [on line] <http://www.jornaldomeioambiente.com.br/JMA-Banners.asp>. Acesso em 3 jun. 2006.

BROWN, R.; LOCKWOOD, A. H.; SONAWANE, B. R. Neurodegenerative diseases: an overview of environmental risk factors. Environ. Health Perspect., v. 113, p. 12501256, 2005.

CAREPO, M. S.; AZEVEDO, J. S.; PORTO, J. I.; BENTES-SOUZA, A. R.; BATISTA, J. S.; SILVA, A. L. et al. Identification of Chromobacterium violaceum genes with potential biotechnological application in environmental detoxification. Gen. Mol. Res., v. 3, n. 1, p. 181-94, 2004.

CASTRO-SILVA, M. A.; LIMA, A. O. S.; GERCHENSKI, A. V.; JAQUES, D. B.; RODRIGUES, A. L.; SOUZA, P. L.; RÖRIG, L. R.. Heavy metal resistance of microorganisms isolated from coal mining environments of Santa Catarina. Braz. J. Microbiol., v. 34, n. 1, p. 45-7, 2003.

CERVANTES, C.; ESPINO-SALDAÑA, A. F.; ACEVEDO-AGUILAR, F.; LEÓNRODRIGUEZ, I. L., RIVERA-CANO, M. F. et al. Microbial interactions with heavy metals. Rev. Latinoam. Microbiol., v. 48, n.2, p.203-10, 2006.

CRECZYNSKI-PASA, T. B.; ANTONIO, R.V. Energetic metabolism of Chromobacterium violaceum. Genet. Mol. Res., v. 3, n. 1, p. 162-6, 2004.

DURAN N.; MENCK C. F. Chromobacterium violaceum : a review of pharmacological and industrial perspectives. Crit. Rev. Microbiol., v. 27, p. 201-222, 2001. 
FRANCHI, J. G.; SÍGOLO, J. B. A utilização de turfa como absorvente de metais pesados. 198f. 2004. Tese (Doutorado em Geociências) - Programa de Pós-Graduação em Geoquímica e Geotectônica, Universidade de São Paulo, São Paulo, 2004.

GRANGEIRO, T. B.; JORGE, D. M.; BEZERRA, W. M.; VASCONCELOS, A. T.; SIMPSON, A. J. Transport genes of Chromobacterium violaceum: an overview. Gen. Mol. Res., v. e, n. 1, p. 117-33, 2004.

GREMION, F.; CHATZINOTAS, A.; KAUFMANN, K.; SILGLER, W. V. ; HARMS, H. Impacts of heavy metal contamination and phytoremediation on a microbial community during a twelve-month microcosm experiment. FEMS Microbiol. Ecol., v. 48, p. 273-83, 2004.

HU, Z.; HIDALGO, G.; HOUSTON, P. L.; HAY, A. G.; SHULER, M. L.; ABRUÑA, H. D. et al. Determination of spatial distributions of zinc and active biomass in microbial biofilms by two-photon laser scanning microscopy. Appl. Evironm. Micróbiol., v. 71, n. 7, p. 4014-21, 2005.

HUNGRIA, M.; NICOLÁS, M. F.; GUIMARÃES, C. T.; JARDIM, S. N.; GOMES, E. A.; VASCONCELOS, A. T. Tolerance to stress and environmental adaptability of Chromobacterium violaceum. Gen. Mol. Res., v. 3, n. 1, p. 102-116, 2004.

LEE, B. G.; GRISCOM, S. B.; LEE, J. S.; CHOI, H. J.; KOH, C. H.; LUOMA, S. N. et al. Influences of dietary uptake and reactive sulfides on metal bioavailability from aquatic sediments. Science, v. 287, p. 282-4, 2000.

LIMA-BITTENCOURT, C. I.; ASTOLFI-FILHO, S.; CHARTONE-SOUZA, E.; SANTOS, F. R.; NASCIMENTO, A. M. Analysis of Chromobacterium sp. natural isolates from different Brazilian ecosystems. BMC Microbiol., v. 7, n. 58-66, 2007.

LOWRY, S. F.; GOODGAME Jr, J. T.; SMITH Jr., J. C.; MAHER, M. M.; MAKUCH, R. W.; HENKIN, R. I.; BRENNAN, M. F. Abnormalities of zinc and copper during total parenteral nutrition. Ann. Surg., v. 189, n. 1, p. 120- 7, 1979.

MACHADO, I. C.; MAIO, F. D.; KIRA, C. S.; CARVALHO, M. F. H. Pd. Cd, Hg, Cu and Zn in mangrove oyster Crassostrea brasiliana Cananéia stuary, São Paulo - Brazil. Rev Inst Adolfo Lutz, v. 61, n. 1, p. 13-18, 2002.

MANDINOV, L.; MANDINOVA, A.; KYURKCHIEV, S.; KYURKCHIEV, D.; KEHAYOV, I.; KOLEV, V.; SOLDI, R. et al. Copper chelation represses the vascular response to injury. PENAS, v. 100, n. 11 p. 6700 - 05, 2003.

NASCIMENTO, A. M. A.; CHARTONE-SOUZA, E. Operon mer: Bacterial resistance to mercury and potential for bioremediation of contaminated environments. Gen. Mol. Res., v. 2, n. 1, p. 92-101, 2003.

PEREIRA, L. B. F.; SOUZA, N. J. A. Distribuição de metais pesados e cianeto total em sedimentos de drenagem e pilha de rejeito na mina de ouro e tungstênio de Bonfim, Lajes, RN. 2005. X In: CONGRESSO BRASILEIRO DE GEOQUÍMICA, $10 \mathrm{E}$ SIMPÓSIO DE GEOQUÍMICA DOS PAISES DE MERCOSUL, 2., 2005, Porto de Galinhas. Anais... Recife: SBG, 2004. 
SÃO PAULO. Secretaria de Estado do Meio Ambiente. Companhia de Tecnologia de Saneamento Ambiental. ISTO - Índice de substâncias tóxicas e organolépticas. 2006. Disponível em: <http://www.cetesb.sp.gov.br/Agua/rios/indice_iap_isto.asp>. Acesso em: 06 jun. 2006.

SHOMRON, N.; MALCA, H.; VIG, I.; AST, G. Reversible inhibition of the second step of splicing suggests a possible role of zinc in the second step of splicing. Nucleic Acids Res., v. 30, n. 19, p. 4127-37, 2002.

TEITZEL, G. M.; PARSEK, M. R. Heavy metal resistance of biofilm and planktonic Pseudomonas aeruginosa. App. Evironm. Microbiol., v. 69, n. 4, p. 2313-20, 2003.

VALLS, M.; LORENZO, V. Exploiting the genetic and biochemical capacities of bacteria for the remediation of heavy metal pollution. FEMS Microbiol. Reviews, v. 26, p. 327-38, 2002. 


\title{
Fármacos, ETEs e corpos hídricos \\ (doi:10.4136/ambi-agua.33)
}

\section{Ricardo Wagner Reis Filho'; Juliana Cristina Barreiro²; Eny Maria Vieira ${ }^{3}$ Quezia Bezerra Cass ${ }^{4}$}

\author{
${ }^{1}$ Doutorando em Ciências da Engenharia Ambiental pela EESC/CRHEA - USP \\ E-mail: reisfo@yahoo.com.br \\ ${ }^{2}$ Pós-doutorado - Grupo de Síntese Orgânica e CLAE - Departamento de Química da UFSCar \\ E-mail: juliana.barreiro@gmail.com \\ ${ }^{3}$ Professora Doutora do DQFM/USP-IQSC \\ E-mail: eny@iqsc.usp.br \\ ${ }^{4}$ Professora Adjunta do Departamento de Química da UFSCar \\ E-mail: quezia@pq.cnpq.br
}

\section{RESUMO}

Na última década, especial atenção tem sido dada à presença de compostos farmacêuticos no ambiente aquático; uma vez que o aporte contínuo e a persistência de várias dessas substâncias podem trazer danos irreversíveis à biota. Sendo assim, o desenvolvimento e aplicação de novas tecnologias de tratamento que permitam a remoção ou diminuição desses contaminantes tem sido objeto de interesse na área de saneamento ambiental. Entretanto, a não existência de programas específicos de monitoramento nas ETEs, impossibilita a avaliação do comportamento dos fármacos nas plantas instaladas. O presente trabalho ilustra os principais fatores envolvidos no aporte desses contaminantes e apresenta um alerta do caminho a ser percorrido, na implementação de sistemas de tratamento adequados para minimizar a deterioração dos ecossistemas aquáticos.

Palavras-chave: ambiente aquático; contaminação; tratamento de água.

\section{Pharmaceutical drugs, WWTP and hydric bodies}

\begin{abstract}
In the last decade, special attention has been given to the presence of pharmaceutical compounds in the aquatic environment; once that continuous supply and persistence of these substances can be severally prejudicial to the biota. Thus, the development and application of new technologies that allows the removal or a decrease in the content of these contaminants has been the focus of the environment sanitation area. However, the absence of specific monitoring programs at the waste water treatment plant (WWTP) does not allow the impact evaluation of pharmaceutical drugs in the installed plants. This work discusses the factors involved in the inflow of these contaminants in the environment, and call attention for the implementation of adequate treatment systems to minimize the deterioration of the aquatic ecosystems.
\end{abstract}

Keywords: aquatic environment; contamination; water treatment. 


\section{INTRODUÇÃO}

O desenvolvimento da indústria farmacêutica, que hoje disponibiliza para o mercado milhões de substâncias com propósito terapêutico, acarretou colateralmente um grave problema ambiental, o qual vem crescendo em atenção e preocupação nas agências controladoras do ambiente de várias nações (Garric et al., 2003). O aporte de substâncias farmacologicamente ativas, denominadas "emergentes", no ambiente advém do uso intenso e extensivo no tratamento de doenças em seres humanos e animais; sendo excretadas na forma não metabolizada ou como um metabólito ativo e introduzidas, principalmente, a partir do lançamento via efluentes municipais e industriais nos corpos hídricos receptores das águas servidas (Chapman, 2006; Petrović et al., 2005; Calamari et al., 2003) (Figura 1).

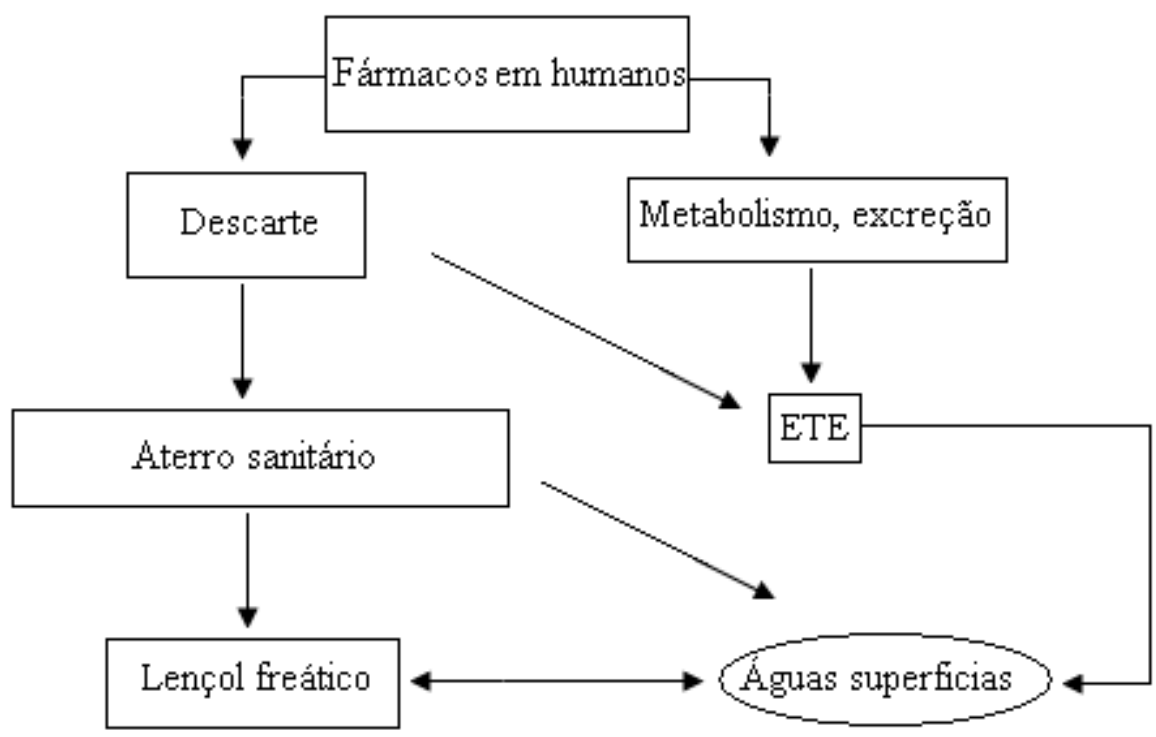

Figura 1. Rotas simplificadas da entrada de fármacos nos ambientes aquáticos.

A quantidade de fármacos ativos (PhACs) e produtos de uso pessoal (PPCPs), fragrâncias, xampus, cosméticos, etc., que adentram ao ambiente em cada ano, é estimada como sendo similar ao total de pesticidas utilizados durante o mesmo período (Daughton; Ternes, 1999). Sendo assim, a contínua entrada pode levar a um aumento na concentração e promover efeitos adversos os quais podem não ser facilmente percebidos nos organismos aquáticos e terrestres (Petrović et al., 2005). Na Tabela 1, encontram-se apresentadas as principais classes de fármacos com potencial de dano para organismos aquáticos (Boxall, 2004; Cunnigham et al., 2006).

Em termos de periculosidade, esses grupos de compostos possuem uma série de agravantes: 1) Muitos são persistentes, assim como seus produtos de degradação; mesmo aqueles que possuem meia-vida curta são passíveis de causar exposições crônicas devido a sua introdução contínua no ambiente; 2) Os fármacos são desenvolvidos para desencadearem efeitos fisiológicos, e, conseqüentemente, a biota se torna mais suscetível a impactos desses compostos; 3) Embora a concentração de alguns fármacos encontradas no ambiente seja baixa, a combinação deles pode ter efeitos pronunciados devido ao mecanismo de ação sinérgica. 
REIS FILHO, R. W.; BARREIRO, J. C.; VIEIRA, E. M.; CASS, Q. B. Fármacos, ETEs e corpos hídricos. Ambi-Agua, Taubaté, v. 2, n. 3, p. 54-61, 2007. (doi:10.4136/ambi-agua.33)

Tabela 1. Principais classes de fármacos com potencial dano para os organismos aquáticos.

\begin{tabular}{ll}
\hline \multicolumn{1}{c}{ Fármacos } & Uso Terapêutico \\
\hline $\begin{array}{l}\text { Amoxicilina, tetraciclina, azitromicina, } \\
\text { ciprofloxacina, eritromicina }\end{array}$ & Antibiótico \\
$\begin{array}{l}\text { Diclofenaco, ibuprofeno } \\
17 \alpha \text {-etinilestradiol, } 17 \beta \text {-estradiol, dietilbestrol, } \\
\text { levonorgestrel, testosterona, tiroxina }\end{array}$ & Antiinflamatório \\
$\begin{array}{l}\text { Reserpina } \\
\text { Omeprazol, ranitidina } \\
\text { Paracetamol, dipirona sódica, codeína, ácido } \\
\text { acetilsalicílico, tramadol }\end{array}$ & Anti-hipertensivo \\
Captopril, propanolol, diltiazem, verapamil, & Antiulceroso \\
lisinopril & Analgésico \\
Diazepam, fluoxetina, citalopram & Cardiovascular \\
\hline
\end{tabular}

Dentre a variedade de fármacos com estruturas, funções e atividades diferentes, existem aqueles que fazem parte do amplo grupo dos compostos disruptores endócrinos (EDCs). Os EDCs são agentes exógenos que interferem no sistema endócrino, o qual sumariamente pode ser descrito como o mecanismo responsável pela manutenção de funções biológicas normais dos organismos por meio da síntese e secreção de hormônios (Lintelmann et al., 2003). Sanderson et al. (2004), estudando a toxicidade de fármacos, demonstraram que os hormônios sexuais encontram-se entre os mais tóxicos para uma série de organismos aquáticos, tais como: cladóceros, peixes e algas. Esses hormônios sintéticos são compostos que agem como sinais e desencadeiam suas funções mesmo em concentrações extremamente baixas (ordem de nanogramas), portanto, representam um perigo potencial para a biota aquática residente nos locais de despejo de efluentes ou esgotos in natura.

\subsection{Adequação das ETEs em uso no Brasil na remoção de PhACs}

Em recente levantamento, o Instituto Brasileiro de Geografia e Estatística (IBGE, 2004) apontou que apenas 20,2\% dos municípios brasileiros possuem condições de esgotamento sanitário adequado com coleta e tratamento. Esse quadro, por si só, é extremamente preocupante em razão dos problemas de saneamento ambiental relacionados com as doenças de veiculação hídrica. Fagundes (2003) estimou que, para cada dólar gasto em saneamento, seriam economizados cem dólares em saúde pública. Sendo que de acordo com especialistas, o país ainda necessita de investimentos da ordem de R \$ 142,4 bilhões para sanar o déficit em coleta e tratamento (Sampaio, 2005).

Estudos de remoção de fármacos em ETE's brasileiras são raros e esparsos. Ternes et al. (1999) e Stumpf et al. (1999) foram os primeiros a reportarem a presença de hormônios, antiinflamatórios e antilipêmicos em esgoto, efluentes e em águas de rios no Estado do Rio de Janeiro.

Em relação às ETE's existentes, Oliveira e Von Sperling (2005a; 2005b) compilaram e avaliaram a eficiência de vários tipos de tecnologias, em razão da remoção de constituintes "clássicos" de águas residuárias. Neste trabalho, estão citadas como as mais comumente empregadas no país: i) Fossa séptica seguida de filtro anaeróbio; ii) Lagoas facultativas, iii) Lagoas anaeróbicas seguidas por facultativas; iv) Lodos ativados; v) Reatores UASB e vi) Reatores UASB seguidos por pós-tratamento.

Considerando os sistemas citados anteriormente, a literatura internacional é vasta e diversificada em relatar os desempenhos dessas tecnologias na redução da concentração de 
fármacos. Jones et al. (2005) compararam o uso do sistema de lagoas (1) e tratamento com lodo ativado (2) durante a remoção do fármaco diclofenaco em lagos da Suíça, e observaram que a remoção foi $76 \%$ maior no sistema 1 . Sendo, o uso de sistemas de lagoas de sedimentação importante durante a degradação de compostos, principalmente aos sensíveis à luz (Jones et al., 2005). Porém em razão do número expressivo de substâncias que adentram as unidades de tratamento, as taxas de remoção são bastante distintas, sendo desde nula a até próximas de 100\% (Svenson et al., 2003; Lee et al., 2003; Carballa, 2004).

Sistemas compostos por lagoa de aeração, sedimentação e lodo estão entre os mais utilizados durante o tratamento de efluentes nas ETEs brasileiras, no entanto a não existência de um programa de monitoramento específico nas ETEs, impossibilita o cálculo das quantidades de fármacos que adentram, e que são removidos nas estações. Principalmente porque o clima local e o regime de operação das unidades são fundamentais para se determinar o comportamento dessas substâncias durante a passagem pelas várias etapas de tratamento.

Dentro do complexo panorama sanitário nacional, parece claro que as tecnologias indicadas como próximas às ideais para remoção desses poluentes são inviáveis de serem adotadas pelos órgãos responsáveis pelo saneamento, devido ao elevado custo de implantação. As tecnologias recomendadas (Drewes et al., 2002; Wintgens et al., 2002; Andersen et al., 2003) são: i) Ozonização, ii) Radiação UV, iii) Adsorção por carvão ativado, iv) Filtração em membranas (nanofiltração), v) Tratamento terciário seguido de injeção em aqüífero (soil-aquifer treatment - SAT), vi) Osmose reversa. Alguns pesquisadores ainda recomendam a separação das águas de toalete das demais para serem especificamente tratadas e disponibilizadas (Larsen et al., 2001; Escher et al., 2006).

Porém, depois que estudos regulares venham a ser implementados, algumas modificações menores talvez possam ser empregadas nas ETEs operantes, como tentativas de se alcançar uma melhor eficiência na remoção de fármacos. O aumento do tempo de retenção hidráulica e conseqüente diminuição da taxa de produção de lodo (maior envelhecimento do lodo) parecem trazer resultados positivos no decréscimo de certos compostos, devido ao incremento da atividade microbiana (Metcalfe et al., 2003). Outra medida a se cogitar é a construção de sistemas alagados artificiais agregados às unidades de tratamento, as quais vêm sendo já há algum tempo avaliadas como uma alternativa viável (relação custo-benefício) para a redução de cargas poluidoras (Greennway; Simpsons, 1996). Os sistemas alagados funcionam como um filtro que retém e processam poluentes orgânicos, permitindo sua decomposição em razão da alta diversidade biológica existente. Embora sejam necessários mais estudos, Matamoros e Bayona (2006) comprovaram a viabilidade desses sistemas na remoção de fármacos em efluentes.

De qualquer forma, além da busca de soluções que propiciem a redução/eliminação da carga de produtos farmacêuticos, é essencial a utilização de ensaios de toxicidade específicos na busca por atividade farmacodinâmica nas águas de lançamento das ETEs.

\subsection{Ecotoxicologia de PhACs}

Resíduos de fármacos em águas de despejo já são comumente reportados em vários estudos (Drewes et al., 2005; Zhou et al., 2006). A presença desses múltiplos compostos implica também múltiplas vias de ação, podendo interferir significativamente na fisiologia, no metabolismo e no comportamento das espécies; além de causar efeitos secundários, os quais podem alterar a defesa imunológica de organismos tornando-os mais susceptíveis à presença de parasitas e doenças. É o caso, por exemplo, dos compostos pertencentes à classe dos antibióticos, os quais são amplamente utilizados, e sua emissão no ambiente pode levar a um 
aumento na ocorrência de bactérias resistentes e conseqüentemente mais nocivas (Petrović et al., 2005).

Os métodos tradicionais empregados na avaliação da toxicidade em organismos aquáticos por substâncias químicas parecem não ser suficientemente adequados. Sendo assim, cabe ressaltar a importância de estudos que propiciem em longo prazo verificarem a influência de concentrações consideradas ambientalmente relevantes a esses organismos. Nesse sentido, instituições e órgãos ambientais de diversos países vêm investindo em pesquisas na procura de indicadores adequados aos efeitos desencadeados por fármacos (Boxall, 2004; Jones et al., 2004; Chapman, 2006; Fent et al., 2006).

Os peixes por sua inerente importância ecológica e econômica estão entre os organismos mais investigados. A fisiologia de seu sistema reprodutivo é regulada por hormônios similares aos dos mamíferos (Mills; Chichester, 2005), portanto, é de se esperar que efeitos ocorram quando do descarte de substâncias estrogênicas no meio aquático. Compostos esteróides usados como contraceptivos orais e de reposição, são potentes e podem causar efeitos biológicos irreversíveis, mesmo quando presentes em baixas concentrações, sendo responsáveis pelas elevadas taxas de demasculinização e feminização em peixes em diversos ambientes aquáticos ao redor do mundo (Edwards et al., 2006).

Nesse contexto, a proteína vitelogenina (VTG) que serve de reserva alimentar para o embrião em desenvolvimento dos vertebrados vivíparos parece ser um biomarcador de exposição apropriado na avaliação dos efeitos de hormônios ou outra classe de fármacos que mimetizam a ação destes. Sua presença em peixes machos só é possível mediante indução externa, já que a sua produção é desencadeada pela atividade de hormônios femininos (Lintelmannn et al., 2003).

Assim sendo, as companhias de saneamento devem se adequar e incluir em sua rotina, variados testes ecotoxicológicos com a finalidade de monitorar os possíveis efeitos deletérios sobre a biota aquática. Conforme é frisado na nova resolução CONAMA 357/2005, em seu capítulo IV inciso $1^{\circ}$ : "O efluente não deverá causar ou possuir potencial para causar efeitos tóxicos aos organismos aquáticos no corpo receptor, de acordo com os critérios de toxicidade estabelecidos pelo órgão ambiental competente" (Brasil, 2005). Sem essa informação é inaceitável que as concentrações de substâncias potencialmente contaminantes presentes nas descargas tenham outro valor além de zero.

\section{CONCLUSÃO}

O controle da presença de resíduos de fármacos deverá ser mais uma variável a ser explorada durante o processo de gestão das estações de tratamento de efluentes. Sua monitoração na carga influente e efluente das estações é de importância crucial na estimativa de impactos nos corpos hídricos receptores de despejos. Embora a implementação de uma rotina de análise seja impraticável devido à enorme variedade de substâncias, esforços devem ser efetivados ao menos para as classes comprovadamente mais tóxica dos produtos de degradação e metabólitos gerados. Ênfase deve ser dada para ensaios ecotoxicológicos de misturas complexas (efluentes), visando à observação de efeitos comprovadamente desencadeados por fármacos.

Outro ponto fundamental na abordagem dessa problemática é em relação ao direcionamento de verbas públicas e privadas para pesquisas em engenharia hidráulica, ambiental, química e saneamento com o objetivo de incentivar e promover pesquisas aplicadas em tecnologias de detecção, degradação e remoção desses compostos ubiquamente utilizados. 


\section{AGRADECIMENTOS}

À Fundação de Amparo à Pesquisa do Estado de São Paulo - FAPESP, processo $\mathrm{n}^{0 .}$ 03705772-0, ao CNPq pelas de bolsas Pós-Doutorado (PDJ) e de Produtividade em Pesquisa (PQ) concedidas à Juliana Cristina Barreiro e Quezia Bezerra Cass, respectivamente.

\section{REFERÊNCIAS}

ANDERSEN, H.; SIEGRIST, H.; HALLING-SǾRENSEN, B.; TERNES,T. A. Fate of estrogens in a municipal sewage treatment plant. Environmental Science \& Technology, v. 37, n. 18, p. 4021-4026, 2003.

BOXALL, A. B. A. The environmental side effects of medication. EMBO reports, v. 5, n. 2, p. 1110-1116, 2004.

BRASIL. Ministério do Meio Ambiente. Conselho Nacional do Meio Ambiente. Resolução CONAMA 357. 2005. Disponível em: <http://www.mma.gov.br/port/conama>. Acesso em: Acesso em 24 julho 2007.

CALAMARI, D.; ZUCCATO, E.; CASTIGLIONI, S.; BAGNATI, R.; FANELLI, R. Strategic survey of therapeutic drugs in the rivers Po and Lambro in northern Italy. Environmental Science \& Technology, v. 37, n. 7, p. 1241-1248, 2003.

CARBALLA, M. Behavior of pharmaceuticals, cosmetics and hormones in a sewage treatment plant. Water Research, v. 38, n. 12, p. 2918-2926, 2004.

CHAPMAN, P.M. Emergin substances - Emerging problems? Environmental Toxicology and Chemistry, v. 25, n. 6, p. 1445-1447, 2006.

CUNNINGHAM, V. L.; BUZBY M.; HUTCHINSON, T.; MASTROCCO, F.; PARKE, N.; RODEN, N. Effects of human pharmaceuticals on aquatic life: next steps. Environmental Science \& Technology, v. 40, n. 11, p. 3456-3462, 2006.

DAUGHTON, C. G.; TERNES, T. A. Pharmaceuticals and personal care products in the environment: agents of subtle change? Environmental Health Perspectives, v. 107, n. S6, p. 907-938, 1999.

DREWES, J. E.; HEBERER, T.; REDDERSEN, K. Fate of pharmaceuticals during indirect potable reuse. Water Science and Technology, v. 46, n. 3, p. 73-80, 2002.

DREWES, J. E.; HEMMIN, J.; LADENBURGER, S. J.; SCHAUER, J.; SONZOGNI, W. An assessment of endocrine disrupting activity changes during wastewater treatment through the use of bioassays and chemical measurements. Water Environment Research, v.77, n.1, p. 12-23, 2005.

EDWARDS, T.M.; MOORE, B.C.; GUILLETTE Jr, L.J. Reproductive dysgenesis in wildlife: a comparative view. International Journal of Andrology, v.29, n.1, p. 109-121, 2006.

ESCHER, B. I.; PRONK, W.; SUTER, M. J. F.; MAURER, M. Monitoring the removal efficiency of pharmaceuticals and hormones in different treatment processes of sourceseparated urine with bioassays. Environmental Science \& Technology, v. 40, n. 16, p. 5095-5101, 2006. 
FAGUNDES, M. V. M. Moeda forte: cada dólar aplicado em esgoto pode valer 100 dólares em saúde. Revista Bio, v. 26, p. 20-21, 2003.

FENT, K.; WESTON, A. A.; CAMINADA, D. Ecotoxicology of human pharmaceuticals. Aquatic Toxicology, v. 76, n. 2, p. 122-159, 2006.

GARRIC, J.; TILGHMAN, A.; COGOLUĖGNES, A. In: EUROPEAN CONFERENCE ON HUMAN \& VETERINARY PHARMACEUTICALS IN THE ENVIRONMENT (ENVIRPHARMA), 2003, Lyon. Final Report: Summary of the Scientific. Lyon: [S.n.], 2003.

GREENNWAY, M.; SIMPSON, J. S. Artificial wetlands for wastewater treatment, water reuse and wildlife in Queensland, Australia. Water Science and Technology, v. 33, n. 10-11, p. 221-229, 1996.

INSTITUTO BRASILEIRO DE GEOGRAFIA E ESTATÍSTICA- IBGE. Atlas do saneamento. Rio de Janeiro: IBGE, 2004. p. 151.

JONES, O. A. H.; VOULVOULIS, N.; LESTER, J. N. Potential ecological and human health risks associated with the presence of pharmaceutically active compounds in the aquatic environment. Critical Reviews in Toxicology, v. 34, n. 4, p. 335-350, 2004.

Human pharmaceuticals in wastewater treatment processes. Critical Reviews in Environmental Science and Technology, v. 35, n. 4, p. 401-427, 2005.

LARSEN, T. A.; PETERS, I.; ALDER, A.; EGGEN, R.; MAURER, M.; MUNCKE, J. Re-engineering toilet for sustainable waste water management. Environmental Science \& Technology, v. 35, n. 9, p. 192A-197A, 2001.

LEE, H. B.; SARAFIN, K.; PEART, T. E.; SVOBODA, M. L. Acidic pharmaceuticals in sewage - methodology, stability test, occurrence, and removal from Ontario samples. Water Quality Research Journal of Canada, v. 38, n. 4, p. 667-682, 2003.

LINTELMANN, J.; KATAYAMA, A.; KURIHARA, N.; SHORE, L.; WENZEL, A. Endocrine disruptors in the environment (IUPAC Technical Report). Pure and Applied Chemistry, v. 75, n. 5, p. 631-681, 2003.

MATAMOROS, V.; BAYONA, J. M. Elimination of pharmaceuticals and personal care products in subsurface flow constructed wetlands. Environmental Science \& Technology, v. 40, n. 18, p. 5811-5816, 2006.

METCALFE, C. D.; KOENIG, B. G.; TERNES, T. A.; HIRSCH, R. Occurrence of neutral and acidic drugs in the effluents of canadian sewage treatment plants. Environmental Toxicology and Chemistry, v. 22, n. 12, p. 2872-2880, 2003.

MILLS, L. J.; CHICHESTER, C. Review of evidence: are endocrine-disrupting chemicals in the aquatic environment impacting fish populations? Science of the Total Environment, v. 343, n. 1/3, p. 1-34, 2005.

OLIVEIRA, S. M. A. C.; VON SPERLING, M. Avaliação de 166 ETEs em operação no país, compreendendo diversas tecnologias. Parte 1: análise de desempenho. Engenharia Sanitária e Ambiental, v. 10, n. 4, p .347-357, 2005a.

Parte 2: influência de fatores de projeto e operação. Engenharia Sanitária e Ambiental, v. 10, n. 4, p. 358-368, 2005 b. 
PETROVIĆ, M.; HERNANDO, M. D.; DIAZ-CRUZ, M. S.; BARCELÓ, D. Liquid chromatography - tandem mass spectrometry for the analysis of pharmaceutical residues in environmental samples: a review. Journal of Chromatography A, v. 1067, n. 1/2, p. 1-14, 2005.

SAMPAIO, A. R. Década da Água? Revista Bio, v. 34, p. 26-35, 2005.

SANDERSON, H.; BRAIN, R. A.; JOHNSON, D. J; WILSON, C. J.; SOLOMON, K. R. Toxicity classification and evaluation of four pharmaceuticals classes: antibiotics, antineoplastics, cardiovascular, and sex hormones. Toxicology, v. 203, n. 1/3, p. 27-40, 2004.

SVENSON, A.; ALLARD, A. S.; EK, M. Removal of estrogenicity in swedish municipal sewage treatment plants. Water Research, v. 37, n. 18, p. 4433-4443, 2003.

STUMPF, M.; TERNES, T. A.; WILKEN, R. D.; RODRIGUES, S. V.; BAUMANN W. Polar drugs residues in sewage and natural waters in the state of Rio de Janeiro, Brazil. The Science of the Total Environment, v. 225, n. 1-2, p. 135-141, 1999.

TERNES, T.A.; STUMPF, M.; MUELLER, J.; HABERER, K.; WILKEN, R. D.; SERVOS, M. Behavior and occurrence of estrogens in municipal sewage treatment plants $-\mathrm{I}$. Investigations in Germany, Canada and Brazil. The Science of the Total Environment, v. 225, n. 1/2, p. 81-90, 1999.

WINTGENS, T.; GALLENKEMPER, M.; MELIN, T. Endocrine disrupter removal from wastewater using membrane bioreactor and nanofiltration technology. Desalination, v. 146, n. 1/3, p. 387-391, 2002.

ZHOU, P.; SU, C.; LI, B.; QIAN, Y. Treatment of high-strength pharmaceutical wastewater and Removal of Antibiotics in Anaerobic and Aerobic Biological Treatment Processes. Journal of Environmental Engineering, v. 132, n. 1, p. 129-136, 2006. 


\title{
Estudo químico ambiental do rio Murucupi - Barcarena, PA, Brasil, área impactada pela produção de alumínio \\ (doi:10.4136/ambi-agua.34)
}

\section{Simone de Fátima Pereira ${ }^{1}$; Maurício Araújo de Lima²; K'Ellen Heloizy Freitas ${ }^{1}$; Cleide Samara Mescouto ${ }^{1}$; Augusto Fonseca Saraiva ${ }^{2}$}

\author{
${ }^{1}$ Programa de Pós-Graduação em Química - Laboratório de Química Analítica e Ambiental \\ (LAQUANAM) da Universidade Federal do Pará \\ E-mail: simonefp@ufpa.br; heloizygf@yahoo.com.br; samaramescouto@yahoo.com.br \\ ${ }^{2}$ Laboratório Central (LACEN) - ELETRONORTE, PA \\ E-mail: saraiva@eln.gov.br
}

\section{RESUMO}

O presente estudo avalia as condições químicas do rio Murucupi em relação aos parâmetros físico-químicos e à presença de elementos químicos na água e suas correlações. $\mathrm{O}$ rio Murucupi localiza-se na região amazônica próximo a uma planta de produção de alumínio. 13 pontos foram selecionados ao longo do rio. Foram analisados os macroelementos, microelementos, elementos traço (Ca, Mg, Na, K, Fe, Al, Ba, Mn, Sr, Zn, Ni, Pb e Cu) e os parâmetros físico-químicos, acidez, alcalinidade total, matéria orgânica, $\mathrm{pH}$, turbidez, temperatura, condutividade, oxigênio dissolvido (OD) e dureza total. Em relação aos parâmetros físico-químicos somente o pH e o OD apresentaram valores em não conformidade com a faixa de valores estabelecidos pela resolução 357/05 do CONAMA. Quanto aos elementos químicos somente o alumínio (Al: 356,04 $\mu \mathrm{g} / \mathrm{L}$ ) e o ferro (Fe: 1080,80 $\mu \mathrm{g} / \mathrm{L}$ ), estiveram em não conformidade com a legislação. Estes resultados apontam para uma possível influência antropogênica na contaminação dos rios da Amazônia por efluentes da produção do alumínio.

Palavras-chave: rio; metais; Amazônia.

\section{Environmental chemical study of the Murucupi river - Barcarena, PA, Brazil impacted area for the aluminum production}

\begin{abstract}
The present work evaluates the chemical conditions of the Murucupi river with relationship to the physical-chemical parameters and the presence of chemical elements in the water and their correlations among themselves. The Murucupi river is located in the amazon region close to the aluminum production area. 13 points were selected along the river. the Macroelements, microelements, trace elements (Ca, Mg, Na, K, Fe, Al, Ba, Mn, Sr, Zn, Ni, $\mathrm{Pb}$ e $\mathrm{Cu}$ ), and physical-chemical parameters, acidity, total alkalinity, organic matter, $\mathrm{pH}$, turbidity, temperature, conductivity, dissolved oxygen (OD) and total hardness were analyzed. In relation to the physical-chemical parameters only $\mathrm{pH}$ and OD presented values in non conformity with thresholds established as acceptable by CONAMA resolution 357/05. Considering the chemical elements only aluminum (Al: $356.04 \mu \mathrm{g} / \mathrm{L}$ ) and iron (Fe: 1080.80 $\mu \mathrm{g} / \mathrm{L})$ were in non conformity with the legislation. These results show the anthropogenic influence on the contamination of the Amazon rivers from the production of aluminum reject.
\end{abstract}

Keywords: river; metals; Amazon. 
PEREIRA, S. F.; LIMA, M. A.; FREITAS, K. H.; MESCOUTO, C. S.; SARAIVA, A. F. Estudo químico ambiental do rio Murucupi - Barcarena, PA, Brasil, área impactada pela produção de alumínio. Ambi-Agua, Taubaté, v. 2, n. 3, p. 62-82, 2007. (doi:10.4136/ambi-agua.34)

\section{INTRODUÇÃO}

As principais fontes de elementos-traço para o ambiente aquático continental são o intemperismo de rochas e a erosão de solos ricos nesses materiais. Mais recentemente outras fontes de elementos traço têm assumindo grande importância: atividades industriais, por meio de efluentes sólidos que são lançados diretamente na atmosfera e líquidos que são lançados em pequenos córregos ou diretamente em rios e lagos; atividade de mineração; efluentes domésticos e águas superficiais provenientes de áreas onde são utilizados defensivos agrícolas (Esteves, 1988).

Todas as formas de vida na Terra dependem da água para sua sobrevivência. Deve-se lembrar que de toda a água do planeta apenas 3\% são água doce, e desse total 79\% estão sob a forma de geleiras e icebergs, $20 \%$, como água subterrânea e apenas $1 \%$ está diretamente disponível para o uso humano (Baird, 1999). Apesar disso, os reservatórios naturais vêm sendo depositários de uma ampla variedade de subprodutos provenientes da atividade antrópica. A presença de elementos potencialmente tóxicos é responsável por efeitos adversos sobre o ambiente, com repercussão na economia e na saúde pública. A introdução de elementos tóxicos nos sistemas aquáticos ocorre naturalmente pelos processos geoquímicos, no intemperismo e, a contribuição atribuída à atividade humana é um reflexo de sua ampla utilização pela indústria (Yabe; Oliveira, 1998).

A poluição de um ecossistema aquático pode causar alterações das características físicas, físico-químicas, e/ou biológicas, que vêem comprometer os múltiplos usos a que a água se destina (Clarisse et al., 1999).

Alguns metais, tais como manganês, cobre e zinco, quando presentes em quantidades mínimas são importantes para as funções fisiológicas dos organismos vivos e regulam muitos processos bioquímicos. Os mesmos metais, contudo, quando despejados nas águas naturais em concentrações elevadas pelos efluentes, efluentes industriais e de mineração podem ter efeitos toxicológicos severos no ambiente aquático e, posteriormente, no homem (Chapman; Kimstach, 1992).

A avaliação da poluição por metais é um importante aspecto da maioria dos programas de controle da qualidade da água. Esses programas incluem elementos como $\mathrm{Al}, \mathrm{Cd}, \mathrm{Cr}, \mathrm{Cu}$, Fe, Hg, Mn, Ni, Pb, Zn e os semi-metais As e Se. A concentração dos diferentes elementos pode variar em um grande intervalo $(0,1-0,001 \mu \mathrm{g} / \mathrm{L})$ em áreas não poluídas e pode chegar a níveis que são perigosos à saúde humana em locais onde as águas sejam influenciadas por atividades antropogênicas (Chapman; Kimstach, 1992).

A manifestação dos efeitos tóxicos causados por metais pesados está associada à quantidade ingerida e pode distribuir-se por todo o organismo, afetando vários órgãos, alterando os processos bioquímicos das organelas e membranas celulares. Esses metais (Al, $\mathrm{Ni}, \mathrm{Ba}, \mathrm{Zn}$, etc) tornam-se tóxicos e perigosos para a saúde humana quando ultrapassam determinadas concentrações-limite. O chumbo, mercúrio, cádmio, cromo e arsênio não desempenham funções nutricionais ou bioquímicas em microorganismos, plantas ou animais (Salgado, 1996; Muñoz et al., 2002).

A produção de alumínio tem apresentado um crescimento constante de $1 \%$ ao ano. As conseqüências ecológicas dessa produção são bem conhecidas: devastação da terra pela exploração da bauxita, usurpação de grandes áreas de terras para a construção de locais de disposição da lama vermelha, poluição em águas superficiais e subterrâneas e poluição do ar por gases resultantes de processos de eletrólise e trituração do alumínio (Salopek; Strazisar, 1993). 
A proposição deste trabalho envolve um estudo químico, baseado no conhecimento de alguns elementos tóxicos presentes na água superficial do rio Murucupi. Destaca-se que esse rio nasce e atravessa uma região onde está localizado um grande pólo industrial de produção de alumina e alumínio, sendo portanto alvo de despejos tanto industriais como domésticos. A obtenção desses dados deve-se ao fato que na área de estudo ocorrem freqüentemente acidentes ambientais pelo vazamento da lixívia sódica contendo resíduos do processamento da bauxita, que acabam por atingir os rios Murucupi e Pará.

As águas do rio Murucupi, de acordo com a resolução 357/05 do Conselho Nacional do Meio Ambiente (Brasil, 2005), podem ser classificadas na área estudada como águas de rio de classe 2, já que são destinadas tanto para abastecimento urbano (cidades de Barcarena e Vila do Conde), onde se faz tratamento convencional, quanto para suprir as necessidades de populações ribeirinhas.

O município de Barcarena situa-se a nordeste do estado do Pará entre os paralelos $1^{\circ}$ $30^{\prime} \mathrm{S}$ a $1^{\circ} 40^{\prime} \mathrm{S}$ e entre os meridianos $48^{\circ} 30^{\prime} \mathrm{W}$ a $48^{\circ} 50^{\prime} \mathrm{W}$. A geologia local faz parte da bacia sedimentar da foz do rio Amazonas; os terrenos são representativos do grupo Pará, caracterizado por depósitos de areia, siltes, argilas e concreções lateríticas. O sistema estudado foi o rio Murucupi localizado no município de Barcarena no estado do Pará (Figura $1)$.

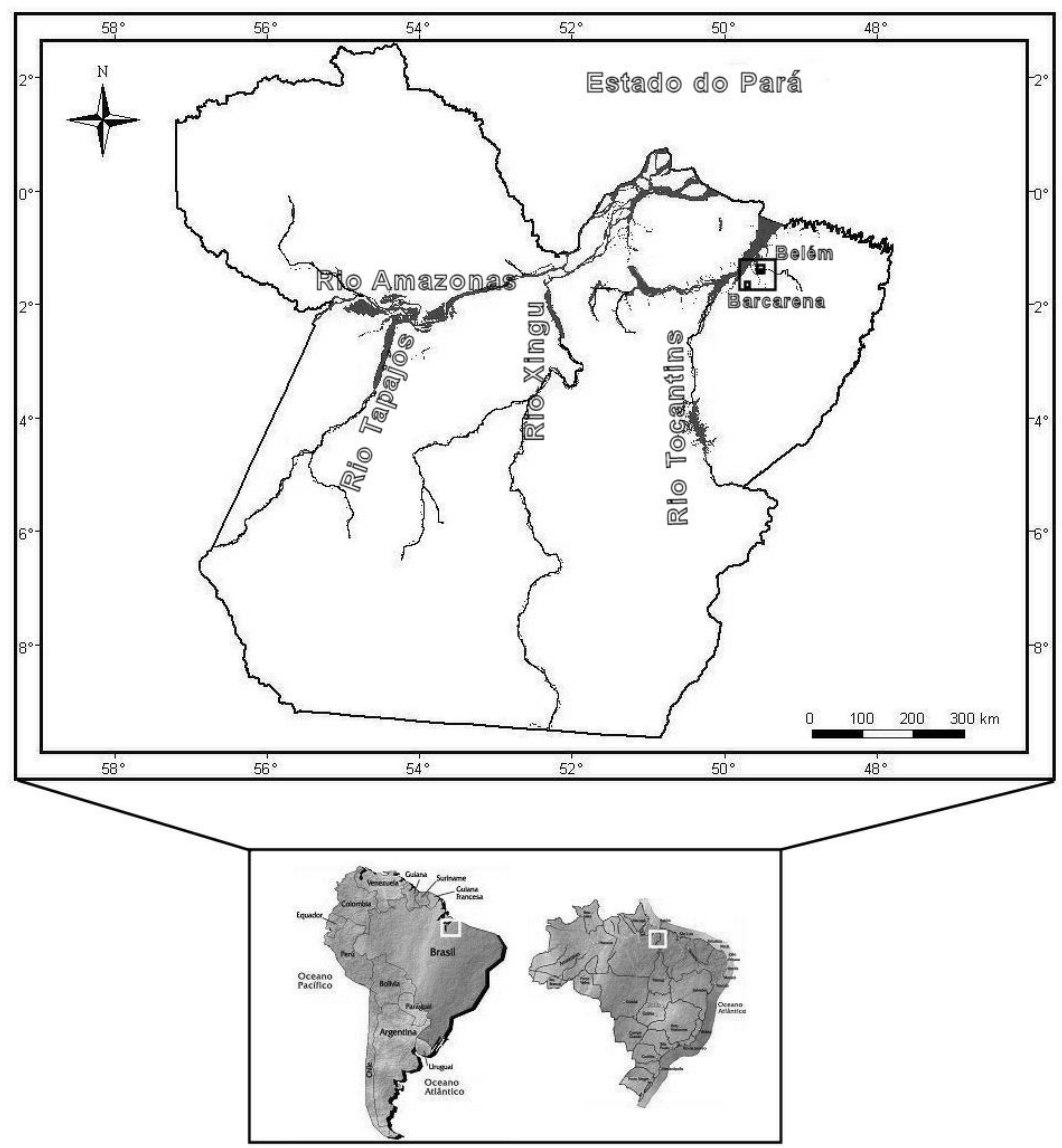

Figura 1. Mapa de localização da área estudada. 
O município de Barcarena tem hoje cerca de 60 mil habitantes, segundo dados estatísticos do IBGE (IBGE, 2000). As principais atividades produtivas do município são a agricultura e a indústria. A cidade vive hoje sérios problemas ambientais relativos não só às indústrias, como também relativo aos problemas de saneamento básico (lixões, efluentes domésticos e sanitários). As águas naturais, assim como o ambiente geológico como um todo, interagem permanentemente, ocasionando uma série de transformações químicas.

Despejos de efluentes industriais contendo lama vermelha oriunda do processo de produção de alumina têm sido um problema constante para o ecossistema local (Figura 2).

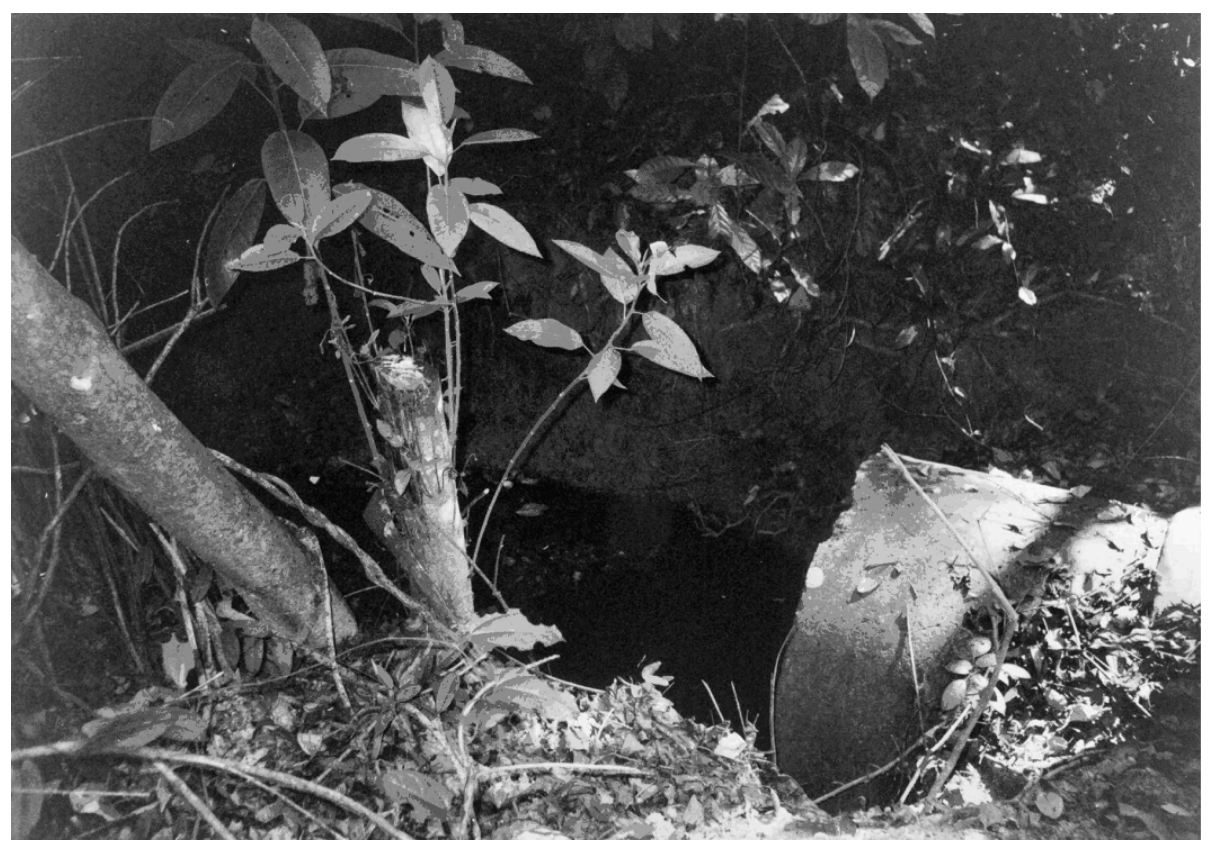

Figura 2. Tubulação de efluentes domésticos e industriais no rio Murucupi.

A "lama vermelha" é o nome dado ao resíduo insolúvel que resta após a digestão da bauxita pelas soluções de hidróxido de sódio, na fabricação de alumina pelo processo Bayer. O rejeito contém, bauxita original, ferro e titânio sob a forma de óxido e toda a sílica e parte do alumínio combinado com o sódio sob a forma de um silicato hidratado de alumínio e sódio de natureza zeolítica. Porém, a produção de lama vermelha pelas fábricas de alumina constitui um problema ambiental de proporções consideráveis, devido às proporções do volume de lama vermelha gerado em uma fábrica de alumina típica e sua causticidade.

Uma fábrica de alumina pode gerar 0,5-2 toneladas de sólidos secos de lama vermelha para cada tonelada de alumina produzida. Além disso, até 2 toneladas de licor cáustico de 520 g/L (como $\mathrm{Na}_{2} \mathrm{CO}_{3}$ ) podem acompanhar cada tonelada de sólidos secos de lama. Sendo assim, é um problema considerável, que atualmente diz respeito a toda fábrica de alumina (Nunn, 1998). Na Tabela 1, é apresentada a composição química da lama vermelha (Santos, 1989).

Tabela 1. Composição química da lama vermelha.

\begin{tabular}{cccc}
\hline Constituinte & Teor (\%) & Constituinte & Teor (\%) \\
\hline $\mathrm{Al}_{2} \mathrm{O}_{3}$ & 17,42 & $\mathrm{Na}_{2} \mathrm{O}$ & 3,36 \\
$\mathrm{Fe}_{2} \mathrm{O}_{3}$ & 51,65 & $\mathrm{MgO}$ & 0,64 \\
$\mathrm{TiO}_{2}$ & 7,49 & $\mathrm{CaO}$ & 1,78 \\
$\mathrm{SiO}_{2}$ & 4,44 & & \\
\hline
\end{tabular}

Fonte: Santos (1989). 


\section{MATERIAL E MÉTODOS}

O sistema estudado foi o rio Murucupi (Figura 3) localizado no município de Barcarena, cujas coletas foram realizadas no período de estiagem (setembro/2006), quando a intrusão das águas da baía de Marajó é mais pronunciada. As coletas foram realizadas com o auxilio de um barco, no sentido da foz para nascente, seguindo a tábua da maré enchente para vazante com periodicidade diária, uma garrafa Van Dorn foi utilizada para a coleta da água superficial. Para o acondicionamento das amostras foram utilizados frascos de polietileno previamente descontaminados com ácido nítrico 10\%, lavadas com água destilada, secas, etiquetadas e lavadas com água do rio no ponto da amostragem (ambiente). De cada ponto foram coletadas duas amostras, uma destinada ao ensaio dos elementos e outra para as análises físico-químicas realizadas em laboratório, ambas foram acondicionadas a $4^{\circ} \mathrm{C}$ e analisadas dentro do prazo, mas apenas as primeiras foram acidificadas até $\mathrm{pH}<2$ com ácido nítrico concentrado (análise dos elementos químicos).

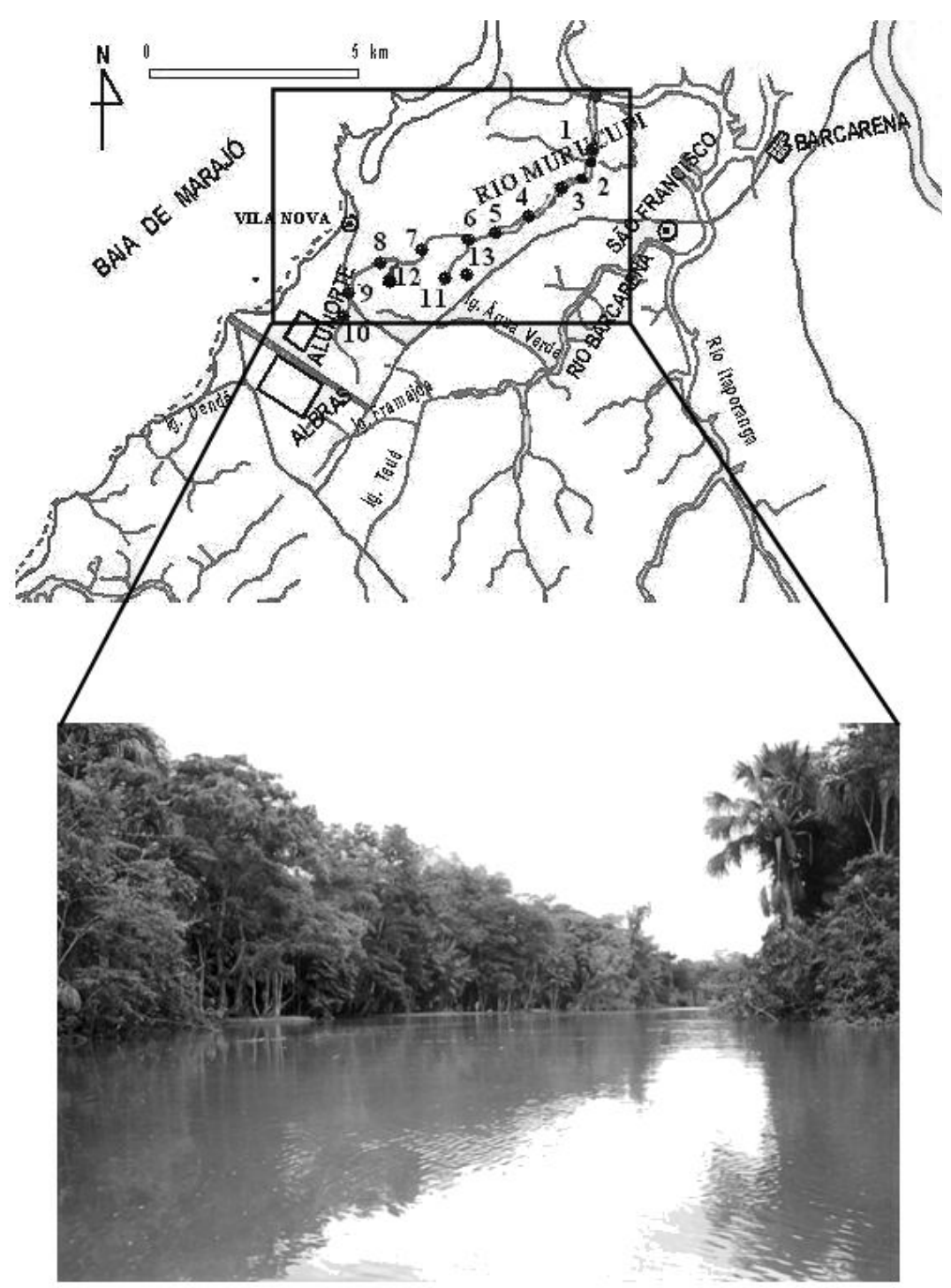

Figura 3. Localização da área de estudo, mostrando o rio Murucupi em destaque. 

ambiental do rio Murucupi - Barcarena, PA, Brasil, área impactada pela produção de alumínio. Ambi-Agua, Taubaté, v. 2, n. 3, p. 62-82, 2007. (doi:10.4136/ambi-agua.34)

Foram selecionados 13 pontos, sendo estes analisados em triplicata. Os locais de amostragem foram georreferenciados por meio de um GPS (global positioning system Etrex/Garmin). Para o planejamento amostral, foi utilizada a tábua de marés diária fornecida pelo DHN. A localização dos pontos obtidos na amostragem está mostrada na Tabela 2.

Os parâmetros $\mathrm{pH}$, temperatura, condutividade, oxigênio dissolvido, turbidez foram analisados no campo. No laboratório foram analisados a alcalinidade, dureza total, matéria orgânica e elementos químicos (Al, As, Ba, Ca, Cd, Cr, Cu, Fe, K, Mg, Mn, Mo, Na, Ni, Pb, $\mathrm{Sr}$ e $\mathrm{Zn}$ ). Os métodos utilizados na análise dos parâmetros físico-químicos e elementos químicos estão mostrados na Tabela 3.

Tabela 2. Localização dos pontos amostrais.

\begin{tabular}{|c|c|c|c|}
\hline Amostra & Coordenadas (GPS) & Amostra & Coordenadas (GPS) \\
\hline RMW-1 & $01^{\circ} 29^{\prime} 34,7^{\prime \prime} \mathrm{S} / 048^{\circ} 39^{\prime} 55,4^{\prime \prime} \mathrm{W}$ & RMW-8 & 01³1'26,7” S/04841'19,7” W \\
\hline RMW-2 & $01^{\circ} 30^{\prime} 27,3^{\prime \prime} \mathrm{S} / 048^{\circ} 40^{\prime} 07,0^{\prime \prime} \mathrm{W}$ & RMW-9 & $01^{\circ} 31^{\prime} 27,1^{\prime \prime} \mathrm{S} / 048^{\circ} 41^{\prime} 24,5^{\prime \prime} \mathrm{W}$ \\
\hline RMW-3 & $01^{\circ} 30^{\prime} 48,4^{\prime \prime} \mathrm{S} / 048^{\circ} 40^{\prime} 28,2^{\prime \prime} \mathrm{W}$ & RMW-10 & $01^{\circ} 31^{\prime} 27,0^{\prime \prime} \mathrm{S} / 048^{\circ} 41^{\prime} 21,7^{\prime \prime} \mathrm{W}$ \\
\hline RMW-4 & $01^{\circ} 30^{\prime} 56,3^{\prime \prime} \mathrm{S} / 048^{\circ} 40^{\prime} 42,7^{\prime \prime} \mathrm{W}$ & RMW-11 & $01^{\circ} 31^{\prime} 27,1^{\prime \prime} \mathrm{S} / 048^{\circ} 41^{\prime} 24,3^{\prime \prime} \mathrm{W}$ \\
\hline RMW-5 & $01^{\circ} 31^{\prime} 11,4^{\prime \prime} \mathrm{S} / 048^{\circ} 40^{\prime} 50,1^{\prime \prime} \mathrm{W}$ & RMW-12 & $01^{\circ} 31^{\prime} 27,1^{\prime \prime} \mathrm{S} / 048^{\circ} 41^{\prime} 24,0^{\prime \prime} \mathrm{W}$ \\
\hline RMW-6 & $01^{\circ} 31^{\prime} 23,0 ” \mathrm{~S} / 048^{\circ} 41^{\prime} 9,5 ” \mathrm{~W}$ & RMW-13 & $01^{\circ} 31^{\prime 2} 27,1^{\prime \prime} \mathrm{S} / 048^{\circ} 41^{\prime} 24,8^{\prime \prime} \mathrm{W}$ \\
\hline RMW-7 & $01^{\circ} 31^{\prime 2} 27,4^{\prime \prime} \mathrm{S} / 048^{\circ} 41^{\prime} 15,1^{\prime \prime} \mathrm{W}$ & & \\
\hline
\end{tabular}

Tabela 3. Métodos, equipamentos e ensaios utilizados.

\begin{tabular}{llll}
\hline \multicolumn{1}{c}{ Parâmetro } & \multicolumn{1}{c}{ Método } & \multicolumn{1}{c}{$\begin{array}{c}\text { Equipamento } \\
\text { marca/modelo }\end{array}$} & \multicolumn{1}{c}{ Norma } \\
\hline \multirow{4}{*}{ Elementos químicos emissão atômica } & Espectrometria de & $\begin{array}{l}\text { ICP-OES } \\
\text { Varian/Vista-Pro }\end{array}$ & $\begin{array}{l}\text { US-EPA standard } \\
\text { methods 6010 B }\end{array}$ \\
Arsênio & $\begin{array}{l}\text { Espectrometria de } \\
\text { absorção atômica }\end{array}$ & $\begin{array}{l}\text { HGAAS- Varian } \\
\text { SpectraA55-VGA77 }\end{array}$ & \\
Alcalinidade total & Indicador misto & - & ASTM D 1067-82 \\
Dureza total & Titulação com EDTA & - & ASTM D 1126-80 \\
Matéria orgânica & Oxidação com KmnO ${ }_{4}-$ & - \\
pH & Potenciométrico & Schott/ Handylab 1 & ASTM D 1293-78 \\
Condutividade & Condutimétrico & Schott/ Handylab Lf1 & ASTM D 1125-82 \\
Turbidez & Nefelométrico & Orbeco-Hellige/966 & ASTM D 1889-81 \\
Oxigênio dissolvido Oxidimétrico & Quimis/ Q-408 P & ASTM D 888-81 \\
Temperatura & Termômetro & Icel/ TD-910D & - \\
\hline
\end{tabular}

A otimização dos instrumentos utilizados foi realizada pela confecção de curvas analíticas visando à determinação do coeficiente angular (a) e linear (b), e coeficiente de correlação (r) além do cálculo dos limites de detecção (LD) pela análise de 15 brancos (3S) e cálculo do limite de quantificação (LQ). Os limites de detecção e quantificação do instrumento foram determinados segundo as equações 1 e 2 .

$$
\begin{aligned}
& L . D=3 \cdot S D_{\text {branco }} / a \\
& L . Q=10 . S D_{\text {branco }} / a
\end{aligned}
$$




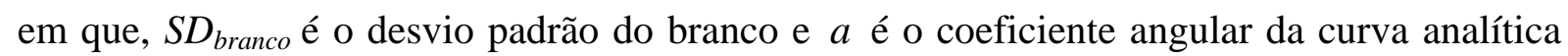
para cada elemento. Os resultados encontrados estão mostrados na Tabela 4.

Todas as curvas se mostraram lineares com coeficientes de correlação acima de 0,9900. Os resultados para o limite de detecção e limite de quantificação mostraram que a técnica do ICP-OES pode ser usada na determinação de elementos em amostras de água, em que estes se encontram em baixas concentrações. O estudo da exatidão foi realizado com a análise do material padrão de referência de água de rio (SRM 1640 NIST) em que os elementos analisados se encontram em concentrações próximas às encontradas nas amostras analisadas neste estudo. No geral, os resultados estão dentro da faixa aceitável para a recuperação dos padrões. Al, Ba, Cd, Cr e Fe apresentaram excelentes recuperações (90-110\%), Ca, Cu, Mg, $\mathrm{Mn}$, Ni e Sr apresentaram boas recuperações com perdas (80-89\%) assim como Mo e Na com boas recuperações com incrementos na concentração do elemento (111-113\%). Os elementos potássio e chumbo apresentaram recuperações regulares abaixo de $80 \%$, indicando perda do elemento ou interferências de origem não determinada.

Tabela 4. Parâmetros analíticos.

\begin{tabular}{ccccccc}
\hline Elementos & $\begin{array}{c}\boldsymbol{\lambda} \\
(\mathbf{n m})\end{array}$ & $\begin{array}{c}\boldsymbol{L D} \\
(\boldsymbol{\mu} \mathbf{g} / \mathbf{L})\end{array}$ & $\begin{array}{c}\boldsymbol{L} \boldsymbol{( \boldsymbol { \mu } / \mathbf { L } )} \\
\end{array}$ & $\boldsymbol{a}$ & $\boldsymbol{b}$ & $\boldsymbol{r}$ \\
\hline $\mathrm{Al}$ & 308,22 & 2,07 & 6,88 & 4,18 & $184,100,9983$ \\
$\mathrm{As}$ & 228,00 & 0,02 & 0,06 & 0,021 & 0,072 & 0,9999 \\
$\mathrm{Ba}$ & 233,53 & 0,76 & 2,54 & 46,93 & $173,630,9998$ \\
$\mathrm{Ca}$ & 317,93 & 16,05 & 53,49 & 15655 & $374,180,9997$ \\
$\mathrm{Cd}$ & 214,44 & 0,66 & 2,19 & 38,51 & $124,220,9990$ \\
$\mathrm{Cr}$ & 267,72 & 0,87 & 2,90 & 17,99 & 60,54 & 0,9990 \\
$\mathrm{Cu}$ & 324,75 & 1,67 & 5,56 & 27,93 & $269,430,9983$ \\
$\mathrm{Fe}$ & 238,86 & 4,77 & 15,91 & 3740 & 54,88 & 0,9998 \\
$\mathrm{~K}$ & 766,47 & 2,46 & 8,21 & 21,05 & 263,5 & 0,9994 \\
$\mathrm{Mg}$ & 278,30 & 8,28 & 27,58 & 381,94 & 19,65 & 0,9999 \\
$\mathrm{Mn}$ & 257,61 & 1,20 & 4,00 & 158,45 & $419,880,9999$ \\
$\mathrm{Mo}$ & 379,83 & 3,82 & 12,74 & 5,33 & $122,820,9973$ \\
$\mathrm{Na}$ & 589,00 & 63,17 & 210,55 & 139846 & $4144,81,0000$ \\
$\mathrm{Ni}$ & 231,60 & 4,22 & 14,06 & 5,07 & 2,659 & 0,9992 \\
$\mathrm{~Pb}$ & 220,35 & 9,68 & 32,25 & 2,59 & 42,22 & 0,9982 \\
$\mathrm{Sr}$ & 407,77 & 0,10 & 0,33 & 2510,4 & 10665 & 0,9992 \\
$\mathrm{Zn}$ & 213,86 & 4,88 & 16,28 & 30,07 & $140,810,9996$ \\
\hline
\end{tabular}

O procedimento da análise estatística adotada foi o da análise inferencial. Esse procedimento abrange a estatística descritiva, análise de regressão e correlação lineares e a estatística multivariada com a análise do dendrograma.

\section{RESULTADOS E DISCUSSÃO}

Os resultados obtidos para os parâmetros físico-químicos na água superficial do rio Murucupi estão mostrados na Tabela 5. Cada ponto reflete a média de sete dias de coleta em que cada amostra foi analisada em triplicata. 
Observou-se que a acidez, alcalinidade, dureza, matéria orgânica e pH se mantiveram praticamente constantes. Apenas com aumento significativo nos pontos RMW-11 e RMW-13, o primeiro ponto corresponde a um braço do rio Murucupi, e o segundo compreende um ponto de coleta onde existe uma tubulação de efluente industrial que é despejado diretamente no rio (Figura 2).

Tabela 5. Resultados das análises físico-químicas.

\begin{tabular}{|c|c|c|c|c|c|c|c|c|c|c|}
\hline Amostra & $\begin{array}{c}\text { Temp. } \\
\text { ambiente } \\
\left({ }^{\circ} \mathrm{C}\right)\end{array}$ & $\begin{array}{c}\text { Temp. } \\
\text { da amostra } \\
\left({ }^{\circ} \mathrm{C}\right)\end{array}$ & $p H$ & $\begin{array}{c}O D \\
(m g / L)\end{array}$ & $\begin{array}{c}\text { turbidez } \\
\text { (UNT) }\end{array}$ & $\begin{array}{c}\text { condutividade } \\
(\mathrm{mS} / \mathrm{cm})\end{array}$ & $\begin{array}{c}\text { acidez } \\
(\mathrm{mg} / \mathrm{L} \\
\mathrm{em} \\
\left.\mathrm{CaCO}_{3}\right)\end{array}$ & \begin{tabular}{|c|} 
alcalinidade \\
total \\
$(\mathrm{mg} / \mathrm{L} d e$ \\
$\left.\mathrm{CaCO}_{3}\right)$
\end{tabular} & $\begin{array}{c}\text { dureza } \\
\text { total } \\
(\mathrm{mg} / \mathrm{L})\end{array}$ & $\begin{array}{c}\text { matéria } \\
\text { orgânica } \\
(\mathrm{mg} / \mathrm{L})\end{array}$ \\
\hline $\begin{array}{l}\text { CONAMA } \\
\text { (rio de classe 2) }\end{array}$ & - & - & $6,0-9,0$ & 5,0 & 100,0 & - & - & - & - & - \\
\hline \multicolumn{11}{|l|}{ RMW - 1} \\
\hline & 28,9 & 29,5 & 5,2 & 6,3 & 30,0 & 3,1 & 17,5 & 50,7 & 13,0 & 3,2 \\
\hline RMW - 2 & 28,0 & 29,4 & 4,4 & 6,2 & 32,0 & 3,4 & 11,0 & 40,0 & 17,5 & 4,1 \\
\hline RMW - 3 & 29,0 & 29,0 & 4,9 & 6,2 & 34,0 & 3,5 & 12,0 & 48,0 & 13,0 & 3,3 \\
\hline RMW - 4 & 28,5 & 29,0 & 4,9 & 5,8 & 21,6 & 3,5 & 13,0 & 42,7 & 13,0 & 3,8 \\
\hline RMW - 5 & 28,0 & 28,5 & 5,2 & 6,2 & 23,6 & 3,6 & 12,0 & 48,0 & 11,0 & 3,4 \\
\hline RMW - 6 & 28,0 & 28,0 & 5,2 & 4,8 & 17,0 & 3,8 & 20,0 & 45,3 & 14,0 & 3,1 \\
\hline RMW - 7 & 28,0 & 28,0 & 5,1 & 4,8 & 21,0 & 4,2 & 36,0 & 40,0 & 13,0 & 3,6 \\
\hline RMW - 8 & 28,0 & 28,0 & 5,2 & 4,2 & 31,5 & 4,3 & 23,0 & 40,0 & 13,0 & 3,4 \\
\hline RMW - 9 & 29,0 & 28,0 & 5,3 & 5,0 & 26,8 & 3,4 & 15,0 & 40,0 & 12,0 & 3,8 \\
\hline RMW - 10 & 28,0 & 27,0 & 5,1 & 4,0 & 24,5 & 4,0 & 29,0 & 28,0 & 12,0 & 3,7 \\
\hline RMW - 11 & 28,0 & 28,0 & 5,7 & 2,6 & 26,8 & 3,8 & 92,0 & 40,0 & 15,0 & 7,1 \\
\hline RMW - 12 & 27,0 & 27,0 & 5,6 & 5,4 & 24,8 & 3,6 & 31,0 & 33,3 & 12,0 & 6,4 \\
\hline RMW - 13 & 28,0 & 28,0 & 6,2 & 5,0 & 27,9 & 3,5 & 104,0 & 232,0 & 21,0 & 9,2 \\
\hline Média & 28,2 & 28,3 & 5,2 & 5,1 & 26,3 & 3,7 & 32,0 & 56,0 & 13,8 & 4,5 \\
\hline Desvio padrão & 0,5 & 0,8 & 0,4 & 1,1 & 4,9 & 0,4 & 30,5 & 53,2 & 2,7 & 1,9 \\
\hline CV (\%) & 1,8 & 2,8 & 7,7 & 21,6 & 18,6 & 10,8 & 95,3 & 95,0 & 19,6 & 42,2 \\
\hline Máximo & 29,0 & 29,5 & 6,2 & 6,3 & 34,0 & 4,32 & 104,0 & 232,0 & 21,0 & 9,2 \\
\hline Mínimo & 27,0 & 27,0 & 4,4 & 2,6 & 17,0 & 3,05 & 11,0 & 28,0 & 11,0 & 3,1 \\
\hline
\end{tabular}

Obs.: Coeficiente de Variação = CV; OD = Oxigênio Dissolvido.

O ponto (RMW-13) apresenta elevados teores de alcalinidade, dureza, acidez, matéria orgânica e pH. Mais adiante quando esse efluente se junta ao corpo do rio, ponto RMW-11, esses parâmetros apresentam-se ligeiramente menores, resultado da dispersão do efluente no rio.

Quanto ao pH, as águas mostram-se ácidas (pH de 4,35 a 6,15), o que está de acordo com a influência do material em suspensão nas águas de rios amazônicos (argila rica em caulinita e ácidos húmicos oriundos da decomposição de matéria vegetal) (Lima; Kobayashi, 1988). Embora haja uma aparente contradição entre as características do efluente de natureza cáustica e o pH encontrado de natureza ácida, estudos realizados na área mostram a capacidade regeneradora de suas águas devido à forte influência das marés que funcionam 

ambiental do rio Murucupi - Barcarena, PA, Brasil, área impactada pela produção de alumínio. Ambi-Agua, Taubaté, v. 2, n. 3, p. 62-82, 2007. (doi:10.4136/ambi-agua.34)

como agente depurador dos rios da região (Lima; Kobayashi, 1988). As grandes variações de $\mathrm{pH}$ seriam notadas apenas por ocasião dos vazamentos de efluentes que logo se dispersam pela influência das marés.

Os valores de oxigênio dissolvido na água tendem a diminuir conforme deslocam-se em direção à nascente do rio, chegando a valores abaixo da resolução 357 do CONAMA (> 5,0 mg/L OD) a partir do ponto RMW-6, com um mínimo (2,6 mg/L) no ponto RMW-11, em que esse valor está associado ao consumo de oxigênio dissolvido na água pela ação redutora da matéria orgânica proveniente do efluente que é despejado no rio.

A média de $\mathrm{pH}$ obtida foi de 5,21, valor abaixo da faixa estabelecida pela resolução 357 do CONAMA ( $\mathrm{pH}$ 6,0 - 9,0), valores maiores foram encontrados à medida que a maré diminuía, com o máximo de 6,15 encontrado no ponto RMW-13 (recebimento de efluente doméstico e efluente da fábrica de alumina), o que está de acordo com o teor de alcalinidade encontrado nesse ponto.

Na Figura 4 é mostrada a variação dos parâmetros ao longo do rio.

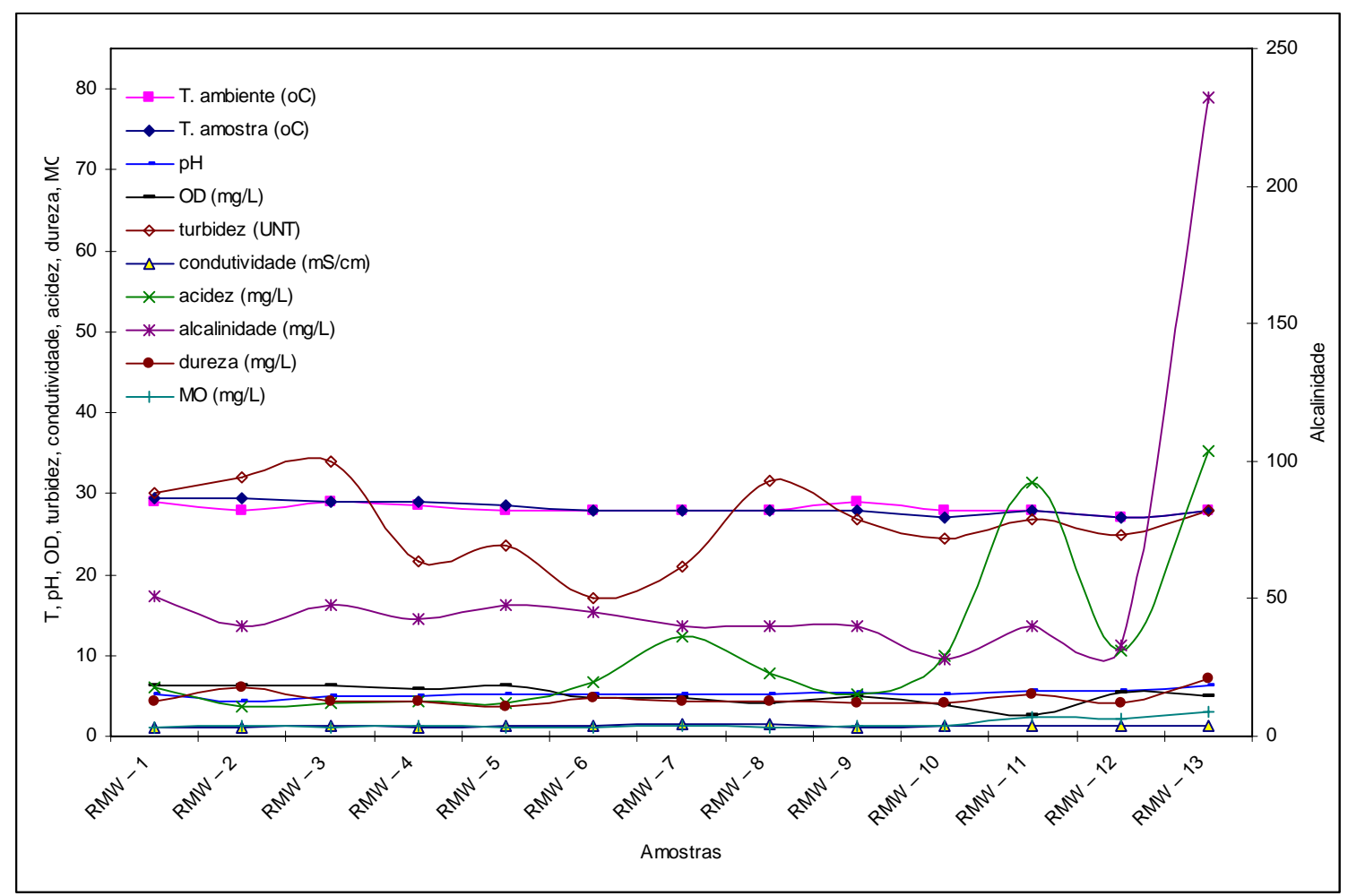

Figura 4. Variabilidade dos parâmetros físico-químicos das águas do rio Murucupi.

A alcalinidade apresentou valores entre 28 e $232 \mathrm{mg} / \mathrm{L}$, com média de $56 \mathrm{mg} / \mathrm{L}$, destacando-se apenas o ponto RMW-13 (efluente), cujo valor foi $232 \mathrm{mg} / \mathrm{L}$, revelando a natureza cáustica do efluente despejado no rio. O mesmo é observado para a acidez cujo valor máximo também se situa no ponto RMW-13.

As medidas de condutividade elétrica variaram de 3,05 a 4,32 mS/cm, com média de 3,67 $\mathrm{mS} / \mathrm{cm}$. Nesse parâmetro observa-se uma mudança no comportamento eletrolítico da água segundo a dinâmica da maré (enchente), tendendo a valores maiores conforme a enchente da maré, comprovando à influência das águas salobras da baia de Marajó, fato muito comum em períodos de estiagem. 
Os valores encontrados neste estudo para as medidas de condutividade são 10,19 vezes maiores que os encontrados por outros autores para o rio Murucupi, no período chuvoso que variaram de 0,03 a 0,69 mS/cm (Lima; Kobayashi, 1988).

Os valores de turbidez obtidos estão no intervalo de 17 a 34 UNT, abaixo da resolução do CONAMA (< 100,0 UNT). Esses valores devem-se, sobretudo, ao material em suspensão, que compreende um complexo coloidal composto de matéria orgânica e de argila rica em caulinita (Lima; Kobayashi, 1988).

Os valores de dureza das águas estão entre 11 e $21 \mathrm{mg} / \mathrm{L}$, com média de 13,81 mg/L de $\mathrm{CaCO}_{3}$. Esses resultados refletem um quadro comum da região estudada, a região em estudo apresenta pobreza de sais de cálcio e magnésio, em que valores mais expressivos estão associados com períodos de estiagem devido à intrusão das águas mais salobras da baía de Marajó no sistema flúvio-estuarino de Barcarena (Lima; Kobayashi, 1988).

Pela análise do coeficiente de variação (CV) foi possível analisar a variabilidade dos parâmetros físico-químicos estudados. A acidez ( $C V=95,3 \%)$ e a alcalinidade $(C V=95,0 \%)$ foram os parâmetros que apresentaram as maiores variações com valores máximos muito acima da média encontrada, esses resultados mostram que existe despejo de efluente doméstico e industrial no rio, que este tem origem cáustica (industrial) e que devido à grande influência das marés ocorre a diluição deles ao longo do rio.

Os altos valores de alcalinidade mostram uma situação até certo ponto incompatível com a natureza dos terrenos ácidos naturais característicos dessas águas regionais. Observa-se, por outro lado, que a alcalinidade (expressa em ppm de $\mathrm{CaCO}_{3}$ ) aumenta com a baixa-mar nos pontos observados no rio Murucupi; tais fatos parecem indicar que incrementos na alcalinidade estejam menos associados a teores mais elevado de bicarbonato, que são característicos de águas de igarapés, e mais associados a despejos de efluentes de origem cáustica. De qualquer modo, há nítida influência da dinâmica das marés da baia do Marajó, mediante forte penetração dessas águas no sistema de bacias de drenagem do rio Murucupi durante as enchentes de maré.

As correlações encontradas para os parâmetros físico-químicos estão mostradas na Figura 5, um gráfico de superfície criado a partir da matriz de correlação gerada pelo programa Statistica (Statsoft). Nele, as áreas escuras indicam elevada correlação entre os parâmetros, conforme indicado pela legenda. No geral, não se observaram muitas correlações entre os parâmetros físico-químicos, apenas boa correlação $(0,6<\mathrm{r}<0,8)$ da acidez com a condutividade e regular correlação $(0,4<\mathrm{r}<0,6)$ entre alcalinidade, $\mathrm{pH}$ e oxigênio dissolvido, indicando que existem alterações desses parâmetros devido às contaminações antropogênicas.

Além da análise da correlação entre os parâmetros físico-químicos também foi aplicada à análise multivariada visando estabelecer quais os parâmetros que apresentam similaridade, representado pela análise do dendrograma (Figura 6). Quanto à similaridade entre os parâmetros físico-químicos, observa-se que os parâmetros com as maiores similaridades foram a matéria orgânica e a condutividade (menores distâncias euclidianas) e o OD e pH, a presença de matéria orgânica é responsável pelo aparecimento de ácidos húmicos e fúlvicos no corpo hídrico influenciando parâmetros como o pH e condutividade que são suscetíveis a presença de $\mathrm{H}^{+}$na água. A alcalinidade se destaca isolada dos demais parâmetros constituindo um resultado com significativa influência antropogênica. 
PEREIRA, S. F.; LIMA, M. A.; FREITAS, K. H.; MESCOUTO, C. S.; SARAIVA, A. F. Estudo químico ambiental do rio Murucupi - Barcarena, PA, Brasil, área impactada pela produção de alumínio. Ambi-Agua, Taubaté, v. 2, n. 3, p. 62-82, 2007. (doi:10.4136/ambi-agua.34)

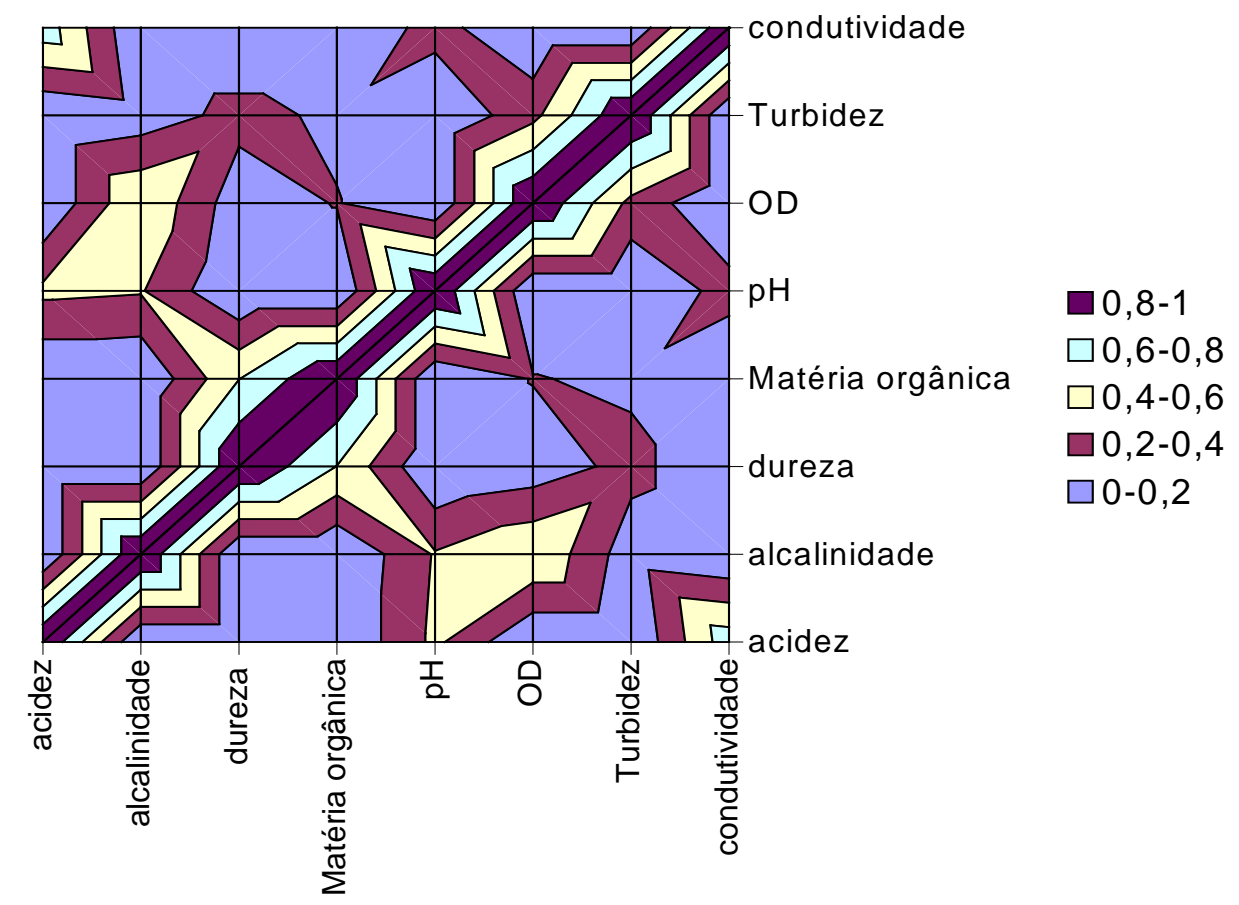

Figura 5. Gráfico de superfície para as correlações encontradas.

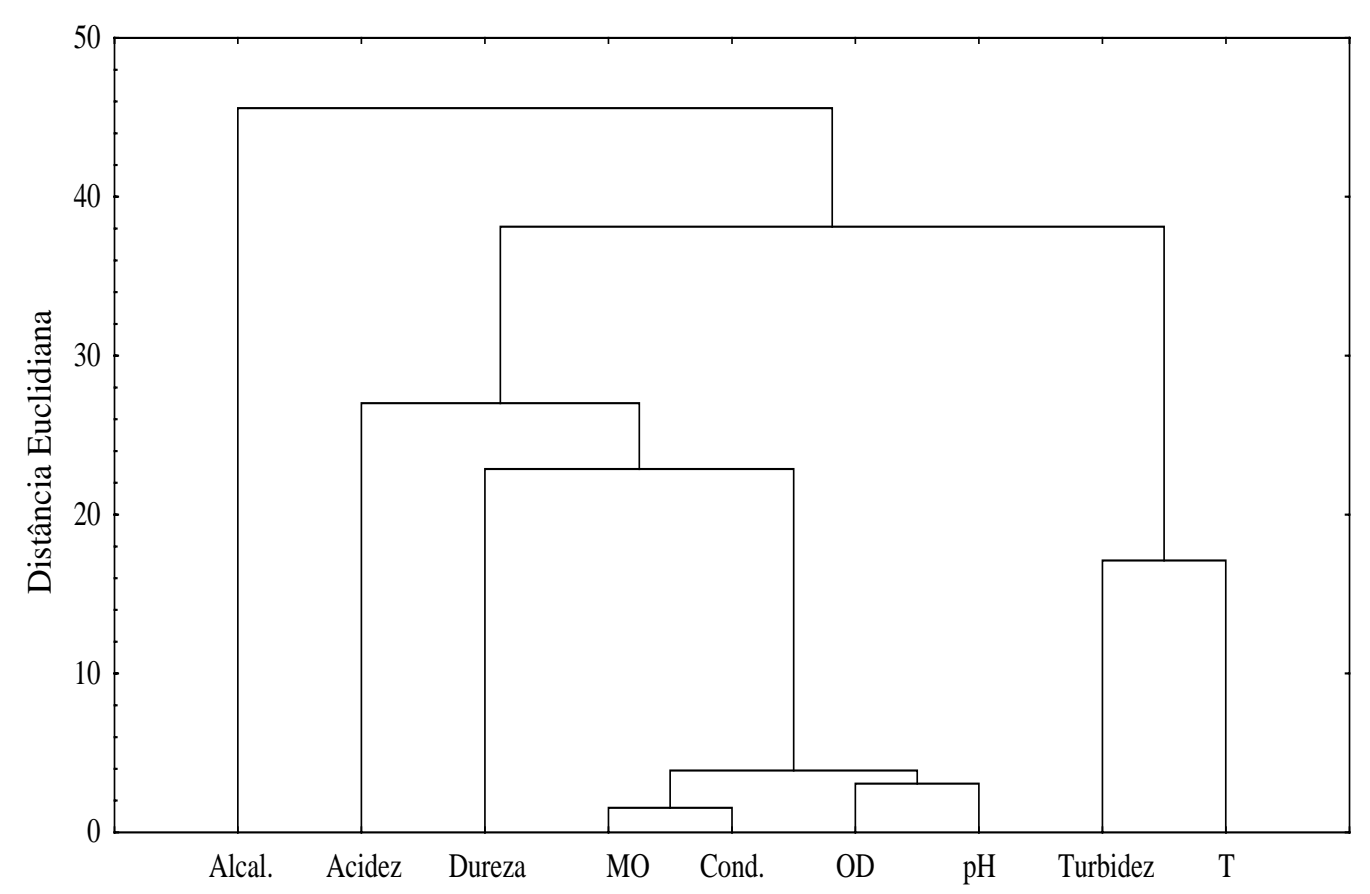

Figura 6. Dendrograma dos parâmetros físico-químicos.

Os resultados obtidos para os elementos químicos na água superficial do rio Murucupi estão mostrados na Tabela 6 . Cada ponto reflete a média de sete dias de coleta onde cada amostra foi analisada em triplicata.

Os gráficos da variabilidade dos elementos químicos ao longo do rio Murucupi estão mostrados nas Figuras 7, 8, 9, 10, 11, 12 e 13. 
PEREIRA, S. F.; LIMA, M. A.; FREITAS, K. H.; MESCOUTO, C. S.; SARAIVA, A. F. Estudo químico ambiental do rio Murucupi - Barcarena, PA, Brasil, área impactada pela produção de alumínio. Ambi-Agua, Taubaté, v. 2, n. 3, p. 62-82, 2007. (doi:10.4136/ambi-agua.34)

Tabela 6. Resultados das análises dos elementos químicos.

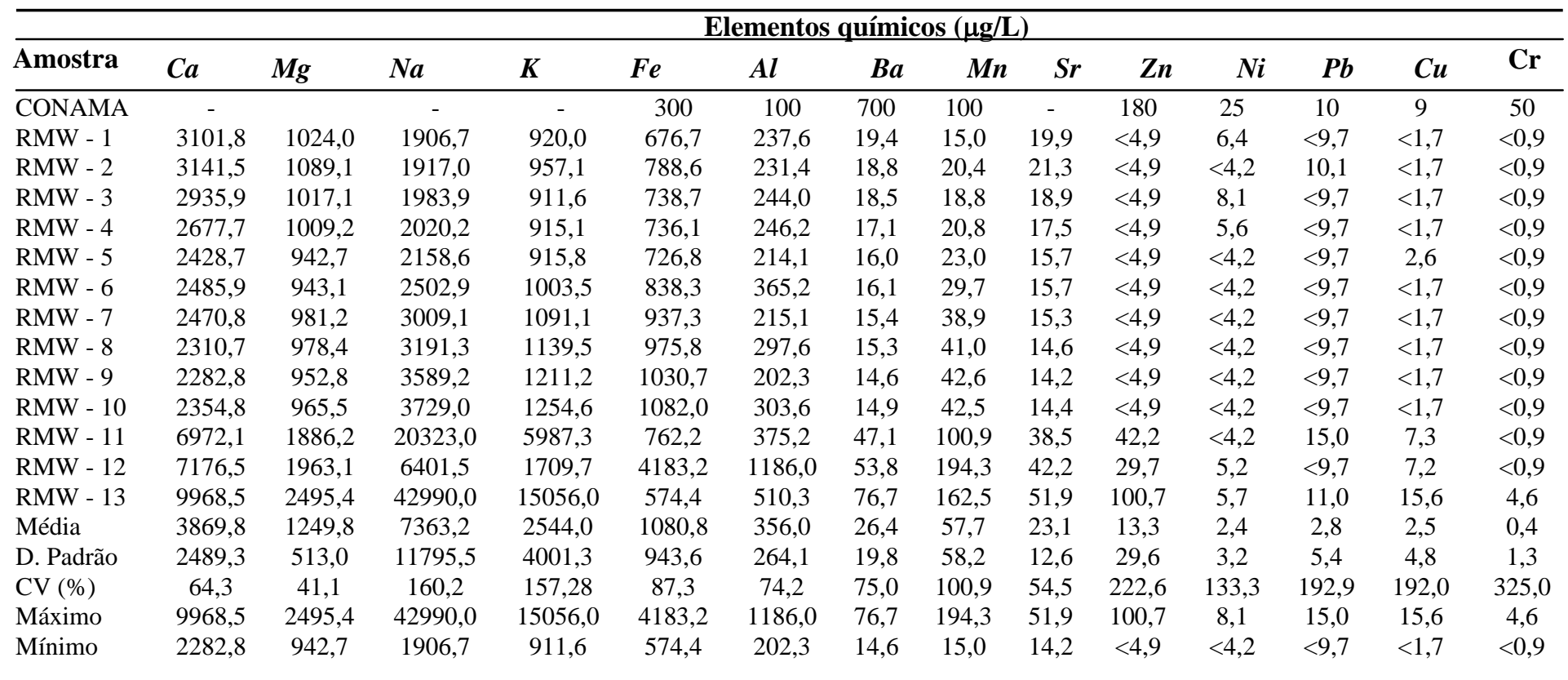

Obs.: CONAMA = Conselho Nacional do Meio Ambiente (resolução 357/05 para rio classe2); D. Padrão = Desvio Padrão; $\mathrm{CV}=$ Coeficiente de Variação.

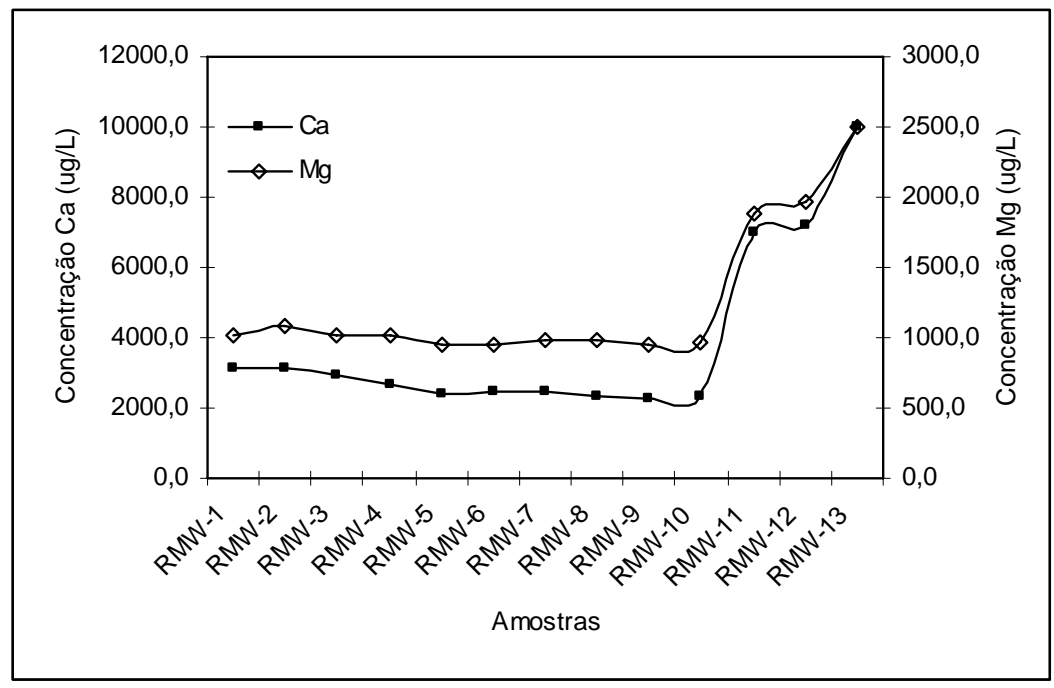

Figura 7. Variabilidade do Ca e Mg ao longo do rio Murucupi. 
PEREIRA, S. F.; LIMA, M. A.; FREITAS, K. H.; MESCOUTO, C. S.; SARAIVA, A. F. Estudo químico ambiental do rio Murucupi - Barcarena, PA, Brasil, área impactada pela produção de alumínio. Ambi-Agua, Taubaté, v. 2, n. 3, p. 62-82, 2007. (doi:10.4136/ambi-agua.34)

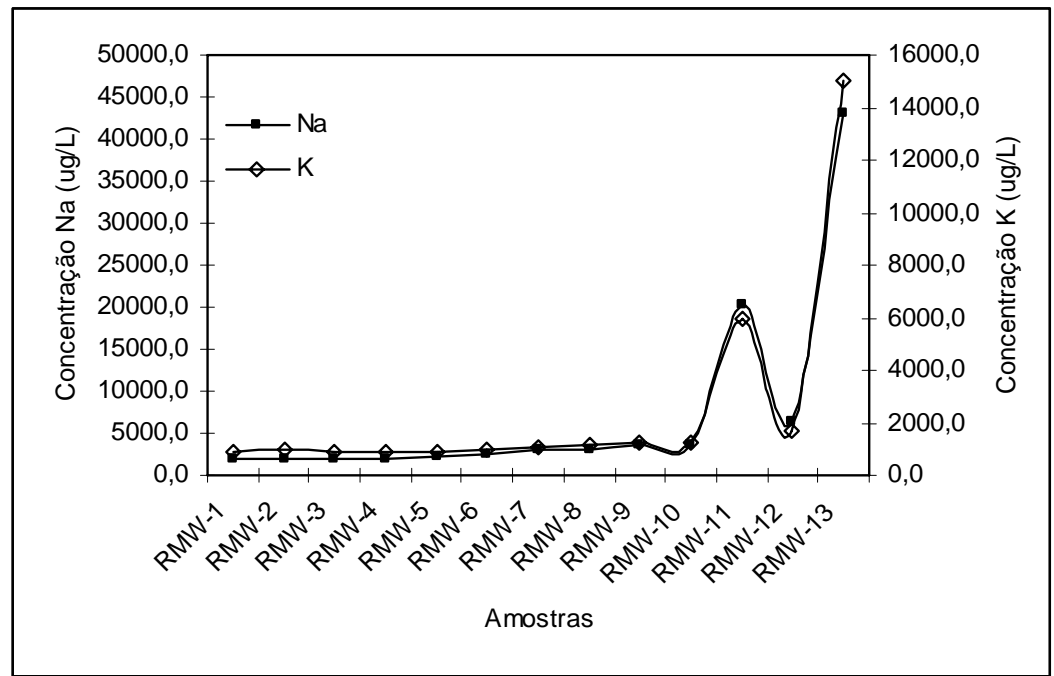

Figura 8. Variabilidade do Na e K ao longo do rio Murucupi.

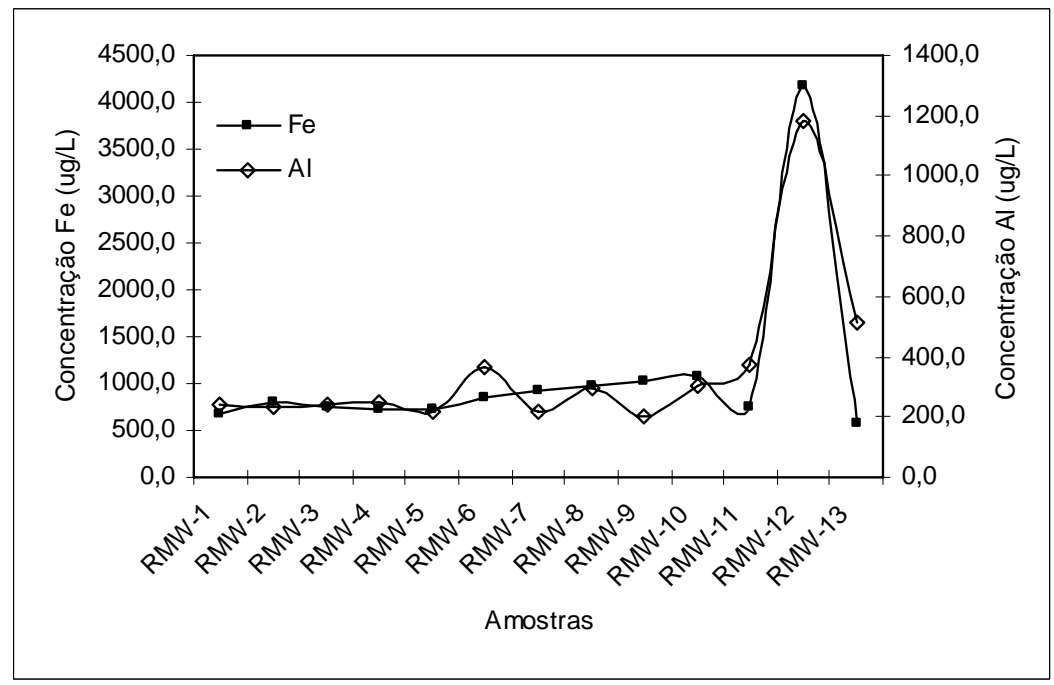

Figura 9. Variabilidade do $\mathrm{Fe} \mathrm{e} \mathrm{Al}$ ao longo do rio Murucupi.

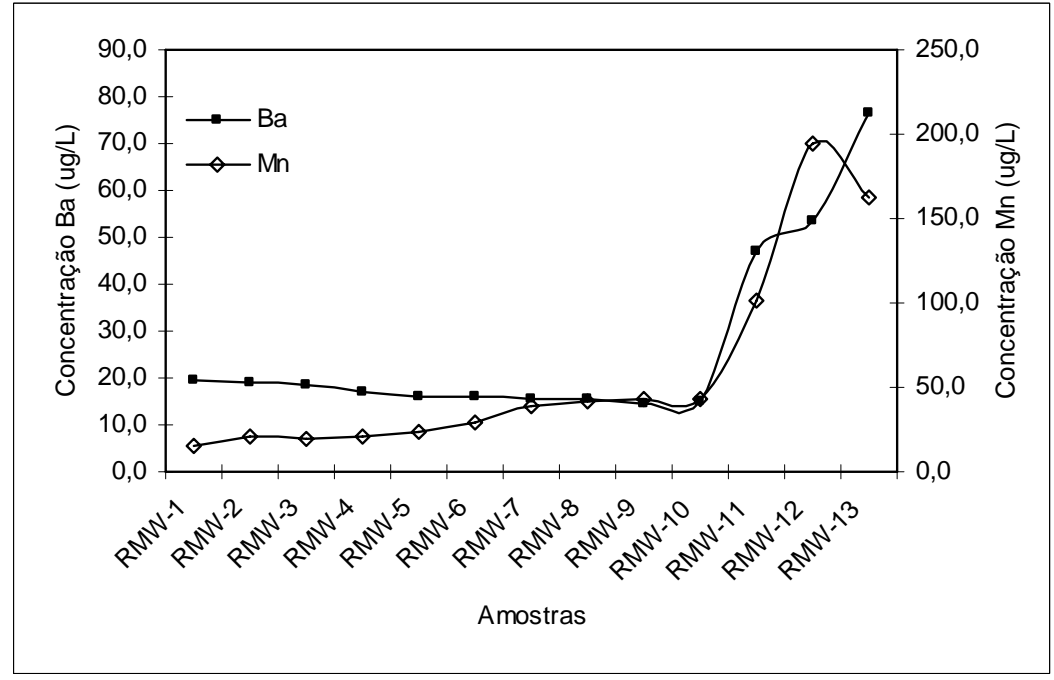

Figura 10. Variabilidade do Ba e Mn ao longo do rio Murucupi. 
PEREIRA, S. F.; LIMA, M. A.; FREITAS, K. H.; MESCOUTO, C. S.; SARAIVA, A. F. Estudo químico ambiental do rio Murucupi - Barcarena, PA, Brasil, área impactada pela produção de alumínio. Ambi-Agua, Taubaté, v. 2, n. 3, p. 62-82, 2007. (doi:10.4136/ambi-agua.34)

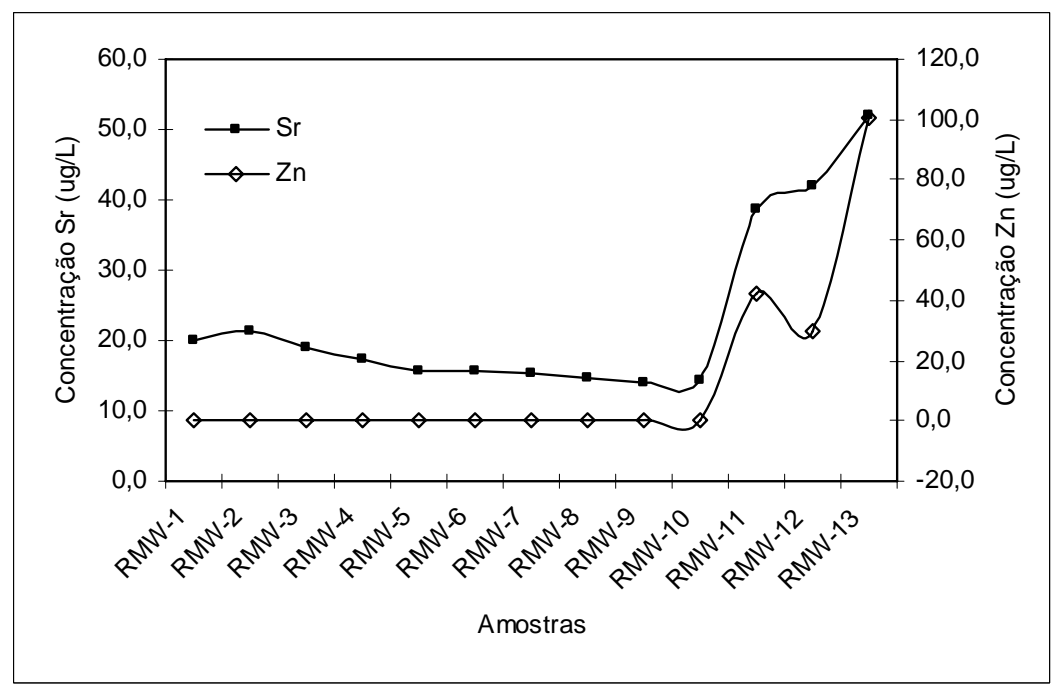

Figura 11. Variabilidade do Sr e Zn ao longo do rio Murucupi.

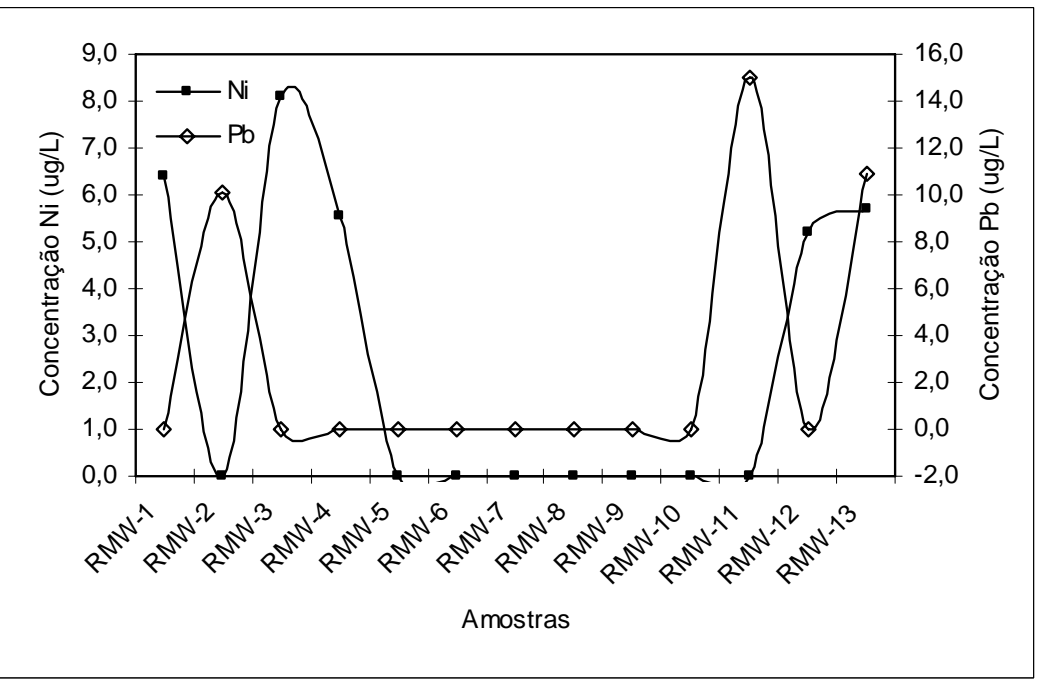

Figura 12. Variabilidade do $\mathrm{Ni}$ e $\mathrm{Pb}$ ao longo do rio Murucupi.

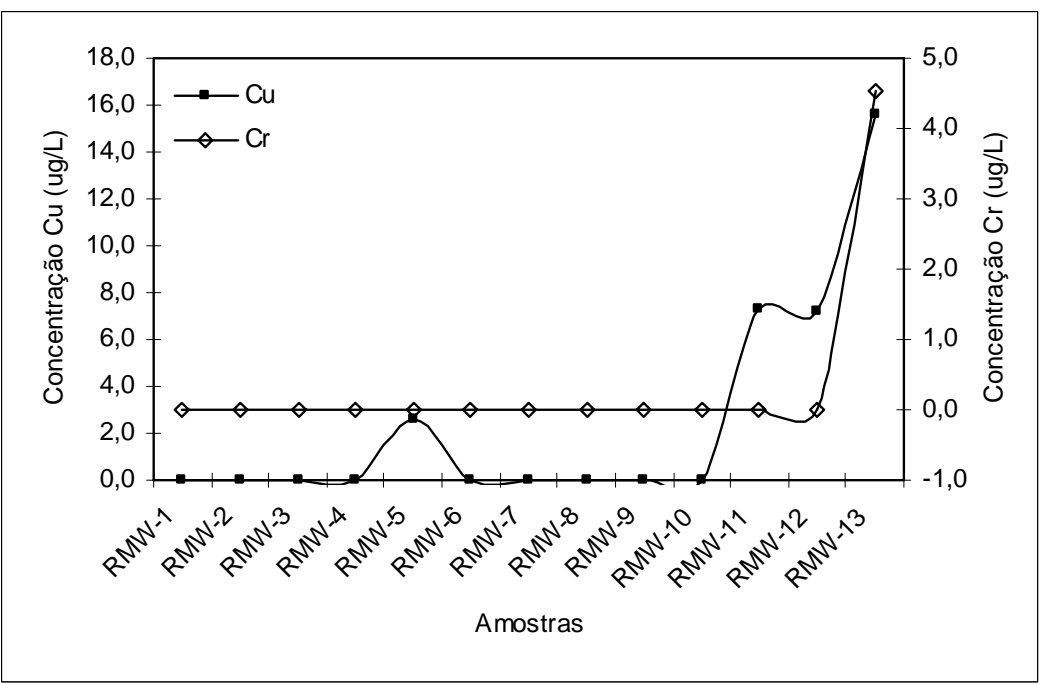

Figura 13. Variabilidade do $\mathrm{Cu}$ e $\mathrm{Cr}$ ao longo do rio Murucupi. 
Foram analisados os seguintes elementos: alumínio, bário, cálcio, cádmio, cromo cobre, ferro, potássio, magnésio, manganês, molibdênio, sódio, níquel, chumbo, estrôncio e zinco. Dentre esses elementos não foi possível detectar a presença de arsênio ( $L D=0,02 \mu \mathrm{g} / \mathrm{L}$ ), cádmio $(\mathrm{LD}=0,66 \mu \mathrm{g} / \mathrm{L})$ e molibdênio ( $\mathrm{LD}=3,82 \mu \mathrm{g} / \mathrm{L})$ nas águas estudadas. O cromo foi detectado apenas no ponto RMW-13 (4,55 $\mu \mathrm{g} / \mathrm{L})$.

De uma maneira geral, o comportamento dos elementos $\mathrm{Ca}, \mathrm{Mg}, \mathrm{Na}, \mathrm{K}, \mathrm{Fe}, \mathrm{Al}, \mathrm{Ba}, \mathrm{Mn}$, $\mathrm{Sr}, \mathrm{Zn}$, e $\mathrm{Cu}$ mantiveram-se constantes ao longo do rio aumentando consideravelmente nos pontos RMW-11, 12 e 13, esse comportamento é provavelmente devido à presença desses elementos nos efluentes industriais e domésticos lançados próximos a esses pontos e que foram incrementados pela ação da maré vazante ao longo dos últimos pontos selecionados. Ni e $\mathrm{Pb}$ tiveram comportamento diferenciado oscilando de valores abaixo do LD do elemento $(<4,2 \mu \mathrm{g} / \mathrm{L}$ para o $\mathrm{Ni}$ e $<9,7 \mu \mathrm{g} / \mathrm{L}$ para o $\mathrm{Pb})$ até valores máximos de $8,1 \mu \mathrm{g} / \mathrm{L}$ para o $\mathrm{Ni}$ no ponto RMW-3 e $15 \mu \mathrm{g} / \mathrm{L}$ no ponto RMW-11 para o chumbo.

Em termos de média, o alumínio $(356,0 \mu \mathrm{g} / \mathrm{L})$ e o ferro $(1.080,0 \mu \mathrm{g} / \mathrm{L})$ apresentaram valores de concentrações 3,56 (Ni) e 3,60 (Fe) vezes maiores que o permitido pela resolução 357/05 do CONAMA ( $<100$ e $<300 \mu \mathrm{g} / \mathrm{L}$ respectivamente). Esses valores elevados demonstram que os despejos oriundos da produção de alumínio estão contribuindo para alterar a qualidade dos rios da Amazônia. O rio Murucupi é um dos afluentes do rio Pará (Vital et al., 1998) que banha a cidade de Belém e outras cidades da região com uma estimativa de mais de 2 milhões de habitantes que mais recentemente tem mostrado uma elevação dos teores de alumínio $(1000,0 \mu \mathrm{g} / \mathrm{L})$ e ferro $(575,0 \mu \mathrm{g} / \mathrm{L})$ devido a vazamentos de efluentes na área industrial de Barcarena (Pereira, 2007b).

A concentração de íons alumínio em águas naturais normalmente é pequena, tipicamente $27 \mu \mathrm{g} / \mathrm{L}$. Esse baixo valor se deve ao fato de que em $\mathrm{pH}$ médio das águas naturais, de 6 a 9, a solubilidade do alumínio contido nas rochas e solos ao qual a água é exposta é muito pequena. A solubilidade do alumínio em águas é controlada pela solubilidade do $\mathrm{Al}(\mathrm{OH})_{3}$, segundo a equação 3:

$$
\mathrm{Al}(\mathrm{OH})_{3(\mathrm{~s})} \longrightarrow \mathrm{Al}^{3+}+3 \mathrm{OH}^{-} \quad \mathrm{K}_{\mathrm{ps}}=10^{-33}
$$

Conforme o equilíbrio da equação 3, percebe-se que a diminuição do $\mathrm{pH}$ das águas naturais provoca um aumento da concentração de íons alumínio na água. Portanto, o alumínio é mais solúvel em águas ácidas $(\mathrm{pH}<6)$ do que aquele em que o $\mathrm{pH}$ não é menor que 6 ou 7 (Baird, 1999). O alumínio solubilizado nas águas dos rios que apresentam pH com caráter ácido, quando em contato com as guelras dos peixes provoca o aumento do $\mathrm{pH}$ e a formação do $\mathrm{Al}_{2}(\mathrm{OH})_{3}$ pouco solúvel nas guelras, o que acaba por matar os peixes sufocados. Os valores encontrados neste trabalho para o alumínio são 13,2 vezes maiores que os valores normais encontrados em águas naturais (Schafer, 1985). Em tempos recentes, o temor quanto a ingestão de alumínio por humanos, pormeio da água potável, deve-se a associação dele como a maior causa da doença de Alzheimer. Pesquisadores concluiram que o consumo de água com mais de $100 \mu \mathrm{g} / \mathrm{L}$ de alumínio, pode levar a danos neurológicos tais como perda de memória e pequeno aumento na possibilidade da incidência da doença de Alzheimer (Baird, 1999). Potencializa outros transtornos mentais, próprios da velhice, interfere na função do magnésio e está relacionado com a debilidade da mucosa digestiva e reduz a absorção do selênio e do fósforo (Lombardi et al., 2001). Sabe-se também que o efeito mais danoso das águas ácidas sobre os peixes se deve ao alumínio. Após ser solubilizado dos solos, ele existe como íon livre em águas ácidas, quando os íons hidróxido precipitam-se como gel nas 
PEREIRA, S. F.; LIMA, M. A.; FREITAS, K. H.; MESCOUTO, C. S.; SARAIVA, A. F. Estudo químico ambiental do rio Murucupi - Barcarena, PA, Brasil, área impactada pela produção de alumínio. Ambi-Agua, Taubaté, v. 2, n. 3, p. 62-82, 2007. (doi:10.4136/ambi-agua.34)

brânquias dos peixes, que são menos ácidas, dificultando a assimilação normal do oxigênio da água e sufocando os peixes (Baird, 1999).

O ferro em altas concentrações pode afetar a saúde humana, pois pode catalisar quimicamente a oxidação de lipídios e outras biomoléculas (Bast et al., 1991). O manganês quando inalado pode causar problemas no pulmão.

O manganês mostrou-se acima da resolução (<100 $\mu \mathrm{g} / \mathrm{L})$ nos pontos RMW-11, 12 e 13. Os elementos $\mathrm{Al}$, Fe e $\mathrm{Mn}$ têm fonte definida no meio ambiente, pois fazem parte da geoquímica local, confirmada pelos resultados do estudo das correlações, não foi possível afirmar que a presença em excesso desses elementos está ligado somente ao efluente industrial despejado no rio Murucupi, entretanto, mesmo sem definir a verdadeira origem dos elementos, pode-se afirmar que em relação aos valores máximos permitidos para rios de classe 2, o rio Murucupi está contaminado por altas concentrações de alumínio e ferro em toda sua extensão e por manganês, em três pontos avaliados que recebem despejos de efluentes domésticos e efluentes industriais. $\mathrm{Ba}, \mathrm{Zn}, \mathrm{Ni}, \mathrm{Pb}$ e $\mathrm{Cu}$ mantiveram as concentrações abaixo da resolução 357/05 do CONAMA (<1000, 180, 25, 30 e $20 \mu \mathrm{g} / \mathrm{L}) \mathrm{com}$ valores condizentes com os de referência em águas doces superficiais. $\mathrm{Ca}, \mathrm{Mg}$, $\mathrm{Na}, \mathrm{K}$ e $\mathrm{Sr}$ não possuem valores limites estabelecidos pelo CONAMA.

Como aconteceu com os parâmetros físico-químicos que variaram principalmente nos pontos RMW-11, 12 e 13 com forte influência dos despejos de efluentes domésticos e efluentes industriais e com a influência da maré, observou-se o mesmo comportamento para alumínio, ferro e manganês no ponto RMW-12 com concentração de 1.186,0 $\mu \mathrm{g} / \mathrm{L}, 4.183,2$ $\mu \mathrm{g} / \mathrm{L}$ e 194,3 $\mu \mathrm{g} / \mathrm{L}$, respectivamente. Observou-se que o ferro começou a apresentar altas concentrações quando do início da vazante da maré, o incremento foi de 5,6\%, chegando a atingir um incremento de 328,69\% no ponto RMW-12 em relação ao início da maré vazante, mostrando assim a influência da intrusão da maré como agente purificador dos corpos hídricos.

No estudo da variabilidade dos resultados, excluindo-se o zinco, níquel, chumbo, cobre e cromo que apresentaram valores abaixo do limite de detecção, de acordo com o cálculo do coeficiente de variação, observou-se que o sódio foi o elemento com maior variabilidade (160,2\%), seguido do potássio (157,28\%) e manganês (100,9\%). O magnésio foi o elemento que menos variou (41,1\%), seguido do estrôncio (54,5\%) e cálcio $(64,3 \%)$. Ferro $(87,3 \%)$, alumínio (74,2\%) e bário (75,0\%) apresentaram variação média. As altas variações apresentadas foram devidas aos altos valores obtidos nos pontos RMW-11, 12 e 13. O lançamento dos efluentes industriais e domésticos no rio Murucupi, oriundos de tubulações clandestinas no interior da floresta, ocasionou a variação observada. As características do efluente podem ocasionar a solubilização de alguns elementos que apresentaram concentrações acima da esperada para água superficial de rios amazônicos (Tabela 7).

Em termos de média, os valores encontrados para o rio Murucupi estiveram todos acima dos valores encontrados em outros rios do estado do Pará, com exceção do bário (1,2 vezes < que a média) e cromo (1,8 vezes < que a média) únicos elementos apresentarem concentração menor que a média encontrada em outros rios. Os elementos que apresentaram os maiores teores em relação à média dos outros rios foram: sódio (3,5 vezes > que a média), alumínio ( 3,1 vezes $>$ que a média) e ferro (2,6 vezes $>$ que a média), todos associados à composição química da lama vermelha. Metais pesados como níquel (2,0 vezes $>$ que a média), zinco (1,7 vezes > que a média), cobre (1,3 vezes > que a média) e chumbo (1,1 vezes > que a média), encontram-se acima da média de outros rios do estado do Pará. Esses resultados mostram que o rio Murucupi está sendo contaminado sistematicamente pelos efluentes lançados em suas 

ambiental do rio Murucupi - Barcarena, PA, Brasil, área impactada pela produção de alumínio. Ambi-Agua, Taubaté, v. 2, n. 3, p. 62-82, 2007. (doi:10.4136/ambi-agua.34)

águas e devido aos altos teores de alumínio e ferro suas águas não são recomendadas para uso sem tratamento.

Na Figura 14, são mostradas as correlações existentes entre os elementos químicos avaliados no rio Murucupi.

Tabela 7. Concentração dos elementos químicos nos rios do estado do Pará ( $\mu \mathrm{g} / \mathrm{L})$.

\begin{tabular}{|c|c|c|c|c|c|c|c|c|}
\hline & Al & As & $B a$ & $C a$ & $C d$ & $\mathrm{Cr}$ & $\mathrm{Cu}$ & Fe \\
\hline CONAMA & 100 & 10 & 700 & - & 1 & 50 & 9 & 300 \\
\hline Rio Pará ${ }^{a}$ & 110,2 & 4,2 & - & - & - & - & 4,7 & - \\
\hline Rio Xingu $^{\mathrm{b}}$ & 54,6 & 4,1 & 47,9 & 4391,7 & - & 0,6 & 0,8 & 508,6 \\
\hline Rio Tapajós ${ }^{c}$ & 280,0 & - & 2,5 & 1670,0 & - & - & - & 564,9 \\
\hline Rio Tocantins ${ }^{\mathrm{d}}$ & 21,3 & - & 40,9 & 3557,4 & 0,1 & 0,8 & 0,2 & 191,5 \\
\hline Rio Murucupi ${ }^{\mathrm{e}}$ & 356,0 & - & 26,4 & 3869,8 & - & 0,4 & 2,5 & 1080,8 \\
\hline Mín. rio Paráa & - & - & - & - & - & - & - & - \\
\hline Mín. rio Xingu ${ }^{\mathrm{b}}$ & 9,1 & - & 1,0 & 303,2 & - & - & - & 4,7 \\
\hline Mín. rio Tapajós ${ }^{\mathrm{c}}$ & 47,6 & - & - & 210,2 & - & - & - & 113,6 \\
\hline Mín. rio Tocantins ${ }^{\mathrm{d}}$ & 1,5 & - & 17,9 & 2320,6 & - & - & - & 22,9 \\
\hline Mín. rio Murucupi ${ }^{\mathrm{e}}$ & 202,3 & - & 14,6 & 2282,8 & - & - & - & 574,4 \\
\hline Máx. rio Paráa & 290,9 & 7,0 & - & - & - & - & 8,9 & - \\
\hline Máx. rio Xingub & 792,4 & 62,2 & 93,8 & 114410,0 & 0,2 & 19,1 & 12,7 & 2426,8 \\
\hline Máx. rio Tapajós ${ }^{c}$ & 788,1 & - & 4,6 & 7066,0 & - & - & - & 1000,2 \\
\hline Máx. rio Tocantins ${ }^{\mathrm{d}}$ & 64,9 & - & 104,2 & 5162,3 & 0,7 & 2,9 & 3,0 & 1170,4 \\
\hline \multirow[t]{2}{*}{ Máx. rio Murucupi ${ }^{\mathrm{e}}$} & 1186,0 & - & 76,7 & 9968,5 & - & 4,6 & 15,6 & 4183,2 \\
\hline & $K$ & $M g$ & Mn & $\mathrm{Na}$ & $\mathrm{Ni}$ & $P b$ & $S r$ & $Z n$ \\
\hline CONAMA & - & - & 100 & - & 25 & 10 & - & 180 \\
\hline Rio Pará ${ }^{a}$ & - & - & 38,1 & - & - & 6,3 & - & 17,2 \\
\hline Rio Xingu ${ }^{b}$ & 1087,8 & 1299,0 & 21,2 & 1814,4 & 0,1 & 0,4 & 15,7 & 5,4 \\
\hline Rio Tapajós ${ }^{c}$ & - & 471,6 & 12,0 & - & - & - & 12,1 & - \\
\hline Rio Tocantins ${ }^{\mathrm{d}}$ & - & 1592,1 & 32,9 & 2408,6 & 2,3 & 0,7 & 30,6 & 1,4 \\
\hline Rio Murucupi ${ }^{\mathrm{e}}$ & 2544,0 & 1249,8 & 57,7 & 7363,2 & 2,4 & 2,8 & 23,1 & 13,3 \\
\hline Mín. rio Paráa & - & - & & - & - & - & - & - \\
\hline Mín. rio Xingu ${ }^{b}$ & 242,4 & 265,9 & 7,4 & 45,9 & - & - & 2,0 & - \\
\hline Mín. rio Tapajós ${ }^{\mathrm{c}}$ & - & 261,2 & 2,2 & - & - & - & 2,9 & - \\
\hline Mín. rio Tocantins ${ }^{\mathrm{d}}$ & - & 1300,6 & 4,1 & 1653,5 & - & - & 21,0 & - \\
\hline Mín. rio Murucupi ${ }^{\mathrm{e}}$ & 911,6 & 942,7 & 15,0 & 1906,7 & - & - & 14,2 & - \\
\hline Máx. rio Pará ${ }^{a}$ & - & - & 108,1 & - & - & 13,4 & - & 52,2 \\
\hline Máx. rio Xingub & 2076,8 & 23834,3 & 66,2 & 5288,1 & 2,9 & 3,5 & 32,4 & 83,1 \\
\hline Máx. rio Tapajós ${ }^{c}$ & - & 1226,3 & 23,0 & - & - & - & 42,6 & - \\
\hline Máx. rio Tocantins ${ }^{\mathrm{d}}$ & - & 2095,3 & 230,4 & 5592,8 & 11,6 & 17,8 & 52,5 & 16,5 \\
\hline Máx. rio Murucupi ${ }^{\mathrm{e}}$ & 15056 & 2495,4 & 194,3 & 42990,0 & 8,1 & 15 & 51,9 & 100,7 \\
\hline
\end{tabular}

Analisando-se o cálculo das correlações entre os elementos, observa-se que cálcio e magnésio têm excelente correlação ( $r>0,8)$ com bário, sódio, potássio, manganês e estrôncio, e boa correlação $(0,6<\mathrm{r}<0,8)$ com alumínio. Sódio e potássio apresentam boa correlação com bário e manganês e excelente correlação com cálcio, magnésio e estrôncio. Manganês apresentou excelente correlação com alumínio, cálcio, magnésio e estrôncio, e boa correlação com bário, ferro, sódio e potássio. O alumínio apresenta excelente correlação com ferro e 
manganês, além de boa correlação com cálcio, magnésio e estrôncio, e apenas regular correlação com bário $(0,4<\mathrm{r}<0,6)$.

Já o ferro apresentou excelente correlação com alumínio e boa correlação com o manganês. A correlação do ferro com o manganês se deve a forma semelhante com que ambos reagem no ambiente aquático. O ferro precipita-se principalmente como carbonato, sulfeto e hidróxido, e solubiliza-se como bicarbonato, isso se aplica ao manganês no ambiente aquático. Além do fato de que a oxidação de ferro e manganês é utilizada como fonte de obtenção de energia para as bactérias do gênero Leptothrix, Crenothrix polyspora, Gallionella, Thiobacillus thiooxidans, Ferrobacillus ferrooxidans e Metallogenium, que metabolizam a matéria orgânica complexada a esses elementos (Baird, 1999).

Destaca-se a excelente correlação entre alumínio e ferro, uma vez que eles estão presentes em grande quantidade no resíduo do processamento da bauxita (lama vermelha).

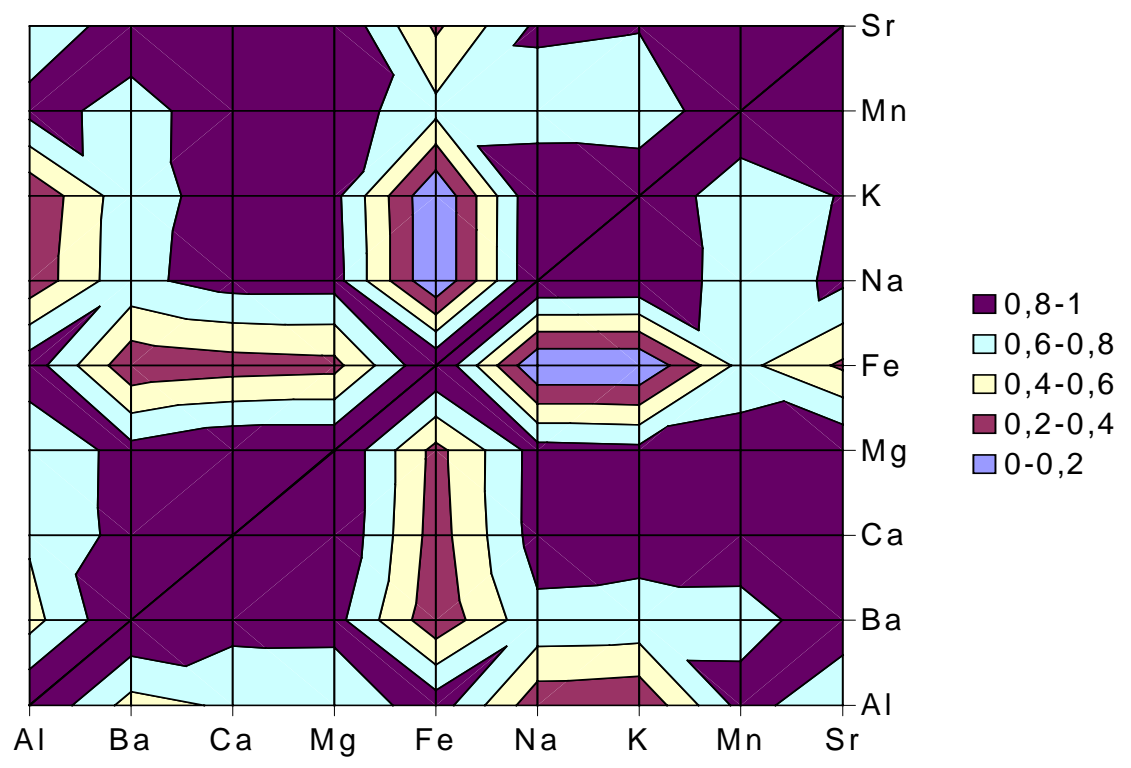

Figura 14. Correlações entre os elementos analisados.

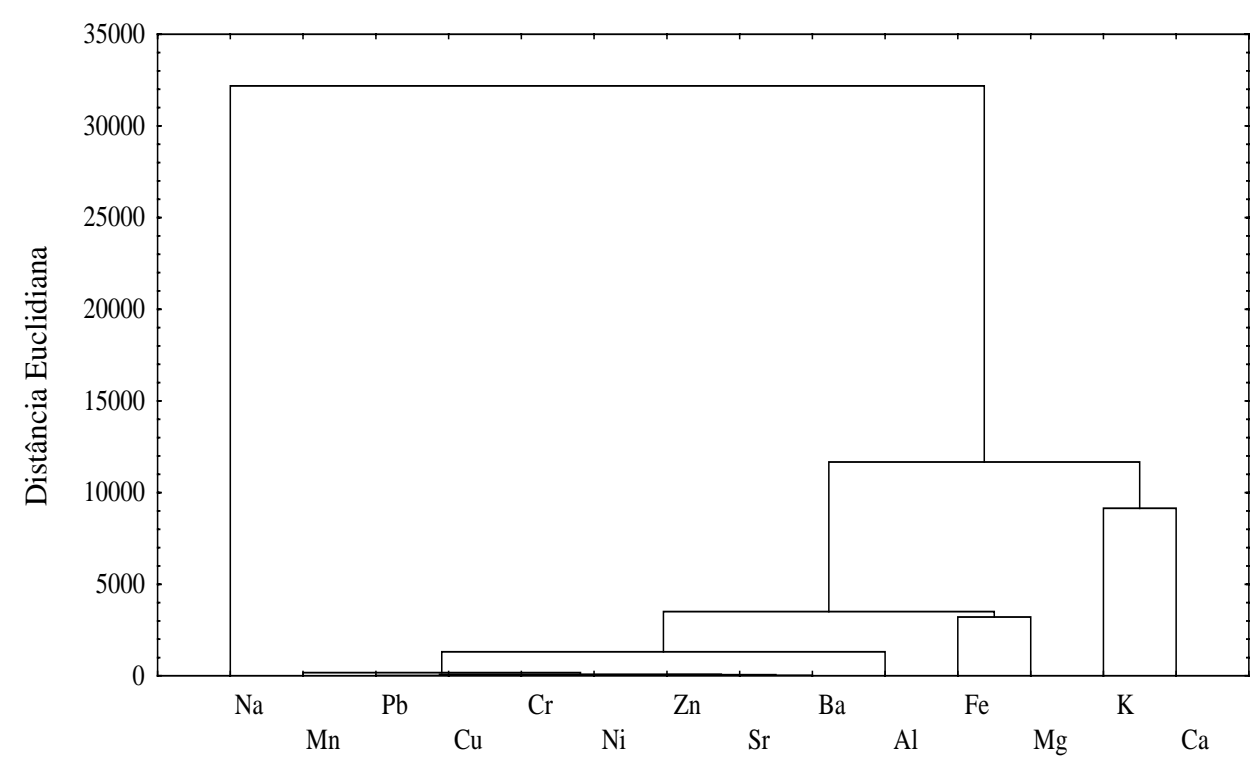

Figura 15. Dendrograma dos elementos químicos. 
Quanto às similaridades entre os elementos químicos, obtidas da análise do dendrograma (Figura 15), observou-se que as melhores similaridades foram entre os elementos $\mathrm{Mn}, \mathrm{Pb}, \mathrm{Cu}$, $\mathrm{Ca}, \mathrm{Ni}, \mathrm{Zn}$, Sr e Ba. O sódio se isolou dos demais elementos com uma indicação de que a presença desse elemento está associado a efluentes ricos em $\mathrm{NaOH}$ usado no tratamento da bauxita visando à extração da alumina. Há relatos da população de vazamentos constantes de um material de aspecto vermelho que mata os peixes do rio e causa problemas a saúde da população local.

\section{CONCLUSÃO}

Considerando que a coleta foi realizada em período de estiagem (setembro), a contribuição do intemperismo, por meio da lixiviação de terrenos, é menos intensa. Nessa época, as águas oceânicas pluviais modificam sazonalmente a composição das águas superficiais do sistema estudado, principalmente pela influência das marés e pelos ciclos hidrogeológicos (enchente, vazante, fluxo, etc).

O teor de eletrólitos encontrados (cálcio, magnésio, sódio e potássio), o pH ácido (4,4 a 6,2), a baixa condutividade elétrica e a pobreza de íons cálcio e magnésio são característicos da região geoquímica amazônica. Isso, também, pode-se dizer dos teores de alumínio e ferro que podem se originar tanto a partir das rochas que contêm esses elementos, assim como da influência da poluição provocada pelo homem.

O aumento do teor de sódio, potássio e manganês podem estar associados a processos hidrogeoquímicos, assim como o intemperismo e também o efluente que é despejado no rio. Deve-se considerar também a intensificação dessas observações quando tem inicio a vazante da maré, do ponto RMW-9 a 13. O ponto RMW-12, apesar de ser uma das nascentes do rio, não pode ser considerado como área preservada, devido à proximidade da área industrial e urbana da região em estudo.

Os parâmetros físico-químicos, na maioria dos casos, apresentaram variações significativas apenas quando teve início a vazante da maré, na qual a influência dos efluentes domésticos e industriais pode ser mais bem observada.

Alguns elementos obtiveram valores de concentrações maiores que o permitido pelo CONAMA, dentre eles o alumínio e o ferro apresentaram-se na totalidade dos pontos analisados e o manganês em três pontos, tendo fonte definida no meio ambiente pois fazem parte da geoquímica local, e em efluentes oriundos de uma indústria produtora de alumina ou pela ação deste sobre as rochas que contêm esses metais, além da ação do intemperismo. A presença dos elementos alumínio e ferro, principalmente, podem causar danos à saúde da população que utiliza a água do rio Murucupi sem tratamento convencional necessitando um cuidado no consumo indiscriminado dessa água.

\section{AGRADECIMENTOS}

Agradecemos o apoio da Eletronorte, CNPq e ao Programa de Pós-Graduação em Química da UFPA.

\section{REFERÊNCIAS}

BAIRD, C. Environmental Chemistry. 2. ed. Ontario: University of Western Ontario, 1999. $557 \mathrm{p}$. 
BAST, A.; HAENEN, G. R. M. M.; DOELMAN, C. J. A. Oxidants and antioxidants: state of the art. The American Journal of Medicine, v. 91, p.3C-25-3C-135, 1991.

BRASIL. Ministério do Meio Ambiente. Conselho Nacional do Meio Ambiente. Resolução 357 de 17 de Março de 2005. Disponível em: <http://www.mma.gov.br/port/ conama>. Acesso em: 12 setembro 2007.

CHAPMAN, D.; KIMSTACH, V. Selection of water quality variables. In: Water quality assessments: a guide to the use of biota, sediments and water in environmental monitoring. $2^{\mathrm{a}}$. ed. Behalf of UNESCO, WHO and UNEP. London: E \& FN Spon, 1992.

CLARISSE, M. D.; AMORIM, M. C. V.; LUCAS, E. F. Despoluição ambiental: uso de polímeros na remoção de metais pesados. Rev. de Química Industrial, v. 715, p. 1624, 1999.

COSTA, A. A. Qualidade dos recursos hídricos da Amazônia rio Tapajós: avaliação de caso em relação aos elementos maiores, menores e traço. 87f. 2006. Trabalho de Conclusão de Curso (Graduação em Licenciatura em Ciências) - Universidade Federal do Pará, Belém, 2006.

ESTEVES, F. A. Fundamentos de limnologia. Rio de Janeiro: Interciência, 1988. 575 p.

FREITAS, K. H. Estudo ambiental das águas superficiais na região denominada Volta Grande do Xingu. 149f. 2005. Dissertação (Mestrado em Química) - Universidade Federal do Pará, Belém, 2005.

INSTITUTO BRASILEIRO DE GEOGRAFIA E ESTATÍSTICA. Dados da população do município de Barcarena-Pa Disponível em: <http://www.ibge.gov.br/home/ estatistica/populacaocenso2000/universo.2000>. Acesso em: 20 ago. 2007.

LIMA, W. N.; KOBAYASHI, C. N. Sobre o quimismo predominante nas águas do sistema flúvio-estuarino de Barcarena, Pa, Geochimica Brasiliensis, v. 2, n.1, p.53-71, 1988.

LOMBARDI, J. V.; BROSSI'GARCIA, A. L.; MACHADO NETO, J. G.; MARQUES, H. L. A.; KUBO, E. Metais Tóxicos - Poluição à mesa,. Revista Brasileira de Toxicologia, v. 35, p. 41, 2001.

MUÑOZ, E.; PALMERO, S.; GARCÍA-GARCÍA, M. A. A Continuous flow system design for simultaneous determination of heavy metals in river water samples. Talanta, v. 57, p. 985-992, 2002.

NUNN, R. F. Advances in Red Mud dewatering and disposal technologies. Light Metals, ISBN: 0-87339-390-2, p. 107-113, fevereiro, 1998.

PEREIRA, S. F. P. Estudo hídrico da represa de Tucuruí com ênfase aos aspectos químicos, biológicos, sócio-ambiental e estatísticos. Brasília: ANEEL, 2007a. 310 p. (Relatório de projeto).

Estudo preliminar dos níveis de contaminação ambiental provocado por vazamento de efluente da Imerys Rio Capim Caulim na região de Vila do Conde Barcarena/PA. Belém: LAQUANAM/ DEMA 2007b. 89 p. 
PIRES, O. O. Caracterização de elementos traço nas águas superficiais da foz do rio Amazonas. 116f. 2005. Dissertação (Mestrado em Química) - Universidade Federal do Pará, Belém, 2005.

SALGADO, P. E. T. Metais em alimentos. In: OGA, S. Fundamentos de toxicologia. São Paulo: Atheneu, 1996. p. 443-460, 1996. cap. 5.2.

SALOPEK, B.; STRAZISAR, J. The influence of Red Mud impoudments on the enviroment. Light Metals, ISBN: 0-87339-197-7 p. 41-44, fevereiro,1993.

SANTOS, P. Ciência e tecnologia de argilas. 2. ed. São Paulo: Edgard Blücher, 1989. vol. 1.

SCHAFER, A. Fundamentos de ecologia e biogeografia das águas continentais. Porto Alegre: Editora da Universidade Federal do Rio Grande do Sul, 1985.

VITAL, H.; STATTEGGER, K.; POSEWANG, J.; THEILEN, F. Lowermost Amazon River: morphology and shallow seismic characteristics. Marine Geology, v. 152, p. 277-294, 1998.

YABE, M. J. S.; OLIVEIRA, E. de. Metais pesados em águas superficiais como estratégia de caracterização de bacias hidrográficas. Química Nova, v. 21, n. 5, p. 551-556, 1998. 


\title{
Avaliação da transformação da paisagem na bacia do ribeirão Vidoca, São José dos Campos, SP, Brasil \\ (doi:10.4136/ambi-agua.35)
}

\author{
André Stempniak ${ }^{1}$; Getulio Teixeira Batista ${ }^{2}$; Ademir Fernando Morelli ${ }^{3}$ \\ ${ }^{1}$ Mestre em Ciências Ambientais, Universidade de Taubaté (UNITAU) \\ E-mail: ast777@gmail.com \\ ${ }^{2}$ Professor do Programa de Pós-Graduação em Ciências Ambientais da Universidade de Taubaté \\ (UNITAU) \\ E-mail: getulio@agro.unitau.br \\ ${ }^{3}$ Professor do Departamento de Engenharia Civil da Universidade de Taubaté (UNITAU) \\ E-mail: afmorelli@uol.com.br
}

\section{RESUMO}

Bacias hidrográficas em áreas urbanas freqüentemente sofrem mudanças drásticas na sua paisagem. O presente trabalho consistiu na análise da transformação da paisagem na Bacia Hidrográfica do Ribeirão Vidoca e do estado de conservação da bacia no período de 1500 a 2003. Com base em técnicas de Sensoriamento Remoto e de Geoprocessamento analisaram-se quatro períodos distintos em termos das mudanças ocorridas: a) no período de 1500 a 1953 ocorreu a transformação da vegetação natural, composta principalmente por Floresta Estacional Semidecidual Aluvial, Floresta Estacional Semidecidual Montana dos Morros da Serra do Mar e Savana Arbórea Aberta, para campo antrópico e pastagens; b) de 1954 a 1985, antes da maciça ocupação urbana, ocorreu uma breve regeneração da Floresta Estacional Semidecidual Aluvial e na região ao sul da Rodovia Carvalho Pinto, pastagens se transformaram em campos antrópicos; c) de 1986 a 1997 ocorreu forte urbanização com conseqüente substituição das áreas com campo antrópico e pastagens; e) de 1998 a 2003 houve a consolidação do processo de urbanização em que áreas de várzea e margens de corpos d’água foram urbanizadas, promovendo impermeabilização dos solos. Concluiu-se que, apesar da criação de uma legislação ambiental conservadora, o processo de urbanização não foi controlado e levou à degradação ambiental hoje observada nessa bacia.

Palavras-chave: bacia hidrográfica; microbacia; paisagem; urbanização; uso da terra.

\section{Evaluation of landscape change in the Vidoca Stream Watershed, São José dos Campos, SP, Brazil}

\begin{abstract}
Hydrographic basins in urban areas frequently undergo drastic landscape changes. This work analyzed the landscape transformation of Vidoca Stream Watershed in the period from 1500 to 2003. Based on Remote Sensing and GIS techniques it was found that: a) Between 1500 and 1953 natural vegetation classes which included Alluvial Semi-decidual Seasonal Forest, Mountainous Semi-decidual Seasonal Forest and Open Arboreal Savannah changed to anthropic fields and grasslands; b) From 1954 to 1985, just before the massive urban occupation of the area, there was a short period of regeneration of the Alluvial Semi-decidual Seasonal Forest above the Carvalho Pinto Highway; later on, the grasslands changed to anthropic fields; c) From 1986 to 1997, a fast urbanization process occurred and resulted in
\end{abstract}


the replacement of the grassland and anthropic fields by urban constructions; d) From 1998 to 2003, with the consolidation of the urbanization process, the urban occupation reached the boundaries of the plateau and the lowlands of the watershed, resulting in soil impermeabilization. The results of this research indicated that the urbanization process was not controlled in spite of restricted legislation and environmental degradation occurred in this studied watershed along of the study period.

Keywords: hydrographic basin; land use; landscape; urbanization; watershed.

\section{INTRODUÇÃO}

Na primeira metade do século XX, o Brasil era um país agrário, com mais da metade de sua população residente no campo. A industrialização, iniciada na segunda metade do século XX, culminou na aceleração do crescimento urbano. Na década de 70 , grande parte da população rural migrou para as cidades e, atualmente, mais de $80 \%$ da população vivem nos centros urbanos. Esse crescimento urbano, sem o devido planejamento, aumentou a pressão sobre os recursos naturais (Sene; Moreira, 1998).

De acordo com Ross (1995), os problemas ambientais nas grandes cidades dos países em desenvolvimento são maiores do que nos países desenvolvidos, pois, além das questões relativas à poluição do ar, da água e do solo gerada pela ocupação urbana desordenada, existem os problemas relacionados com a qualidade de vida das populações de baixa renda, que sobrevivem em condições sanitárias desumanas, em grandes adensamentos demográficos e em áreas muitas vezes desfavoráveis à ocupação. A degradação dos recursos hídricos pela transformação da paisagem, em decorrência de ações antrópicas, modifica a estrutura e a função dos ecossistemas, comprometendo a própria disponibilidade e a qualidade hídrica, e também a qualidade de vida da população.

O conceito de paisagem inclui interações entre elementos bióticos e abióticos, nas quais a vida determina a dinâmica do meio e é determinada pelas alterações naturais e antrópicas. Assim, a urbanização das áreas de várzea e seu entorno sem o devido planejamento causa sérios problemas ambientais. Segundo Coelho Netto (1995), “A Bacia de Drenagem é uma área de superfície terrestre que drena água, sedimentos (particulado) e materiais dissolvidos (matéria orgânica e inorgânica) para uma saída comum, num determinado ponto de um canal fluvial. O limite de uma bacia de drenagem é conhecido como divisor de drenagem ou divisor de águas”. A microbacia do Vidoca deságua na bacia do Rio Paraíba do Sul que é um rio federal que abastece quase 20 milhões de habitantes.

Segundo Casimiro (2004), o Sensoriamento Remoto é uma ferramenta que facilita a identificação de padrões na paisagem, tanto em termos temporais quanto espaciais. A possibilidade de se traduzir a carta ou o mapa para uma linguagem sintética torna a ferramenta Sistema de Informação Geográfica (SIG), aliada à informação do Sensoriamento Remoto, uma ferramenta capaz de traduzir a complexidade da paisagem e sua dinâmica espaço-temporal. Por meio de SIGs, é possível manipular dados provenientes de fotos aéreas, imagens de satélite ou mesmo pontos coletados por um GPS, além de documentos cartográficos (Câmara et al., 1996).

As bacias ou microbacias urbanas normalmente apresentam-se consideravelmente alteradas com prejuízos ambientais. Este trabalho avaliou a transformação da paisagem da Bacia do Vidoca com base em conceitos de ecologia da paisagem para avaliar a interferência do homem nessa bacia. Especificamente, os objetivos do trabalho foram: 1) caracterizar os aspectos físicos e antrópicos da microbacia do Ribeirão Vidoca; 2) avaliar o ambiente 
construído e a transformação da paisagem na microbacia do Vidoca no período de 1953 a 2003.

\section{MATERIAIS E MÉTODOS}

\section{1. Área de estudo}

A Microbacia do Ribeirão Vidoca (Figura 1) se localiza integralmente na região sul do município de São José dos Campos, tendo suas cabeceiras situadas na Província Geomorfológica conhecida como Planalto Atlântico, em uma região de terras altas, constituída predominantemente por rochas cristalinas Pré-Cambrianas e Cambro-Ordovianas. (São Paulo, 1992).

O vale do Ribeirão Vidoca e seus afluentes adentram à Bacia Sedimentar de Taubaté, a qual constitui uma depressão cuja origem está relacionada a movimentos tectonicamente depressivos que sofreram processos de sedimentação. É uma bacia que espelha o grande crescimento do município, com uma área de $43,6 \mathrm{~km}^{2}$, extensão de $16,7 \mathrm{~km}$ e largura média de 2,6km (São Paulo, 1992).

O Comitê para integração das Bacias Hidrográficas do Rio Paraíba do Sul (CEIVAP) considera a Bacia do Vidoca como uma bacia prioritária no gerenciamento dos recursos hídricos na Bacia do Paraíba do Sul. O Vidoca é citado como parte do Plano de Esgotos da ETE Lavapés (CEIVAP, 2000).

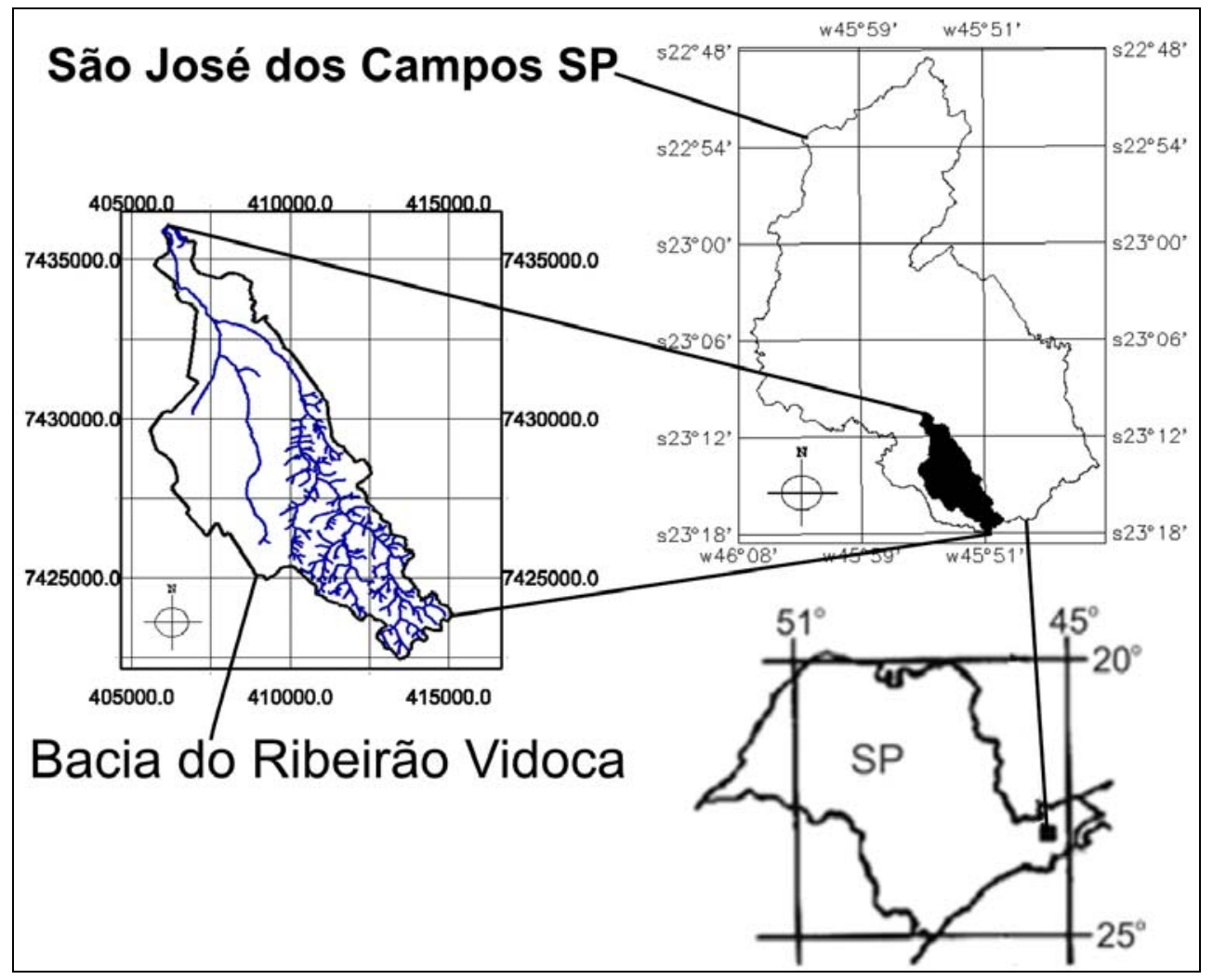

Figura 1. Microbacia do Vidoca e sua localização no município de São José dos Campos, Estado de São Paulo.

O Ribeirão Vidoca (Figuras 2 e 3) tem sua nascente no divisor de águas denominado Itamerim a 793 metros de altitude, próximo ao limite entre os municípios de São José dos Campos e Jacareí. Logo após sua nascente, o ribeirão atravessa a Rodovia Carvalho Pinto, próximo ao bairro Parque Interlagos, recebendo o córrego da Água Clara como seu primeiro 
afluente. Esse córrego é represado logo abaixo da sua nascente, percorrendo um trecho de aproximadamente dois quilômetros antes de desaguar no Vidoca. O Ribeirão Vidoca, seguindo seu curso rumo ao rio Paraíba, após cruzar a Rodovia Presidente Dutra, recebe seu principal afluente, o Córrego Serimbura que, por sua vez, recebe o Córrego Senhorinha, intensamente degradado por esgotos domésticos (São Paulo, 1992).

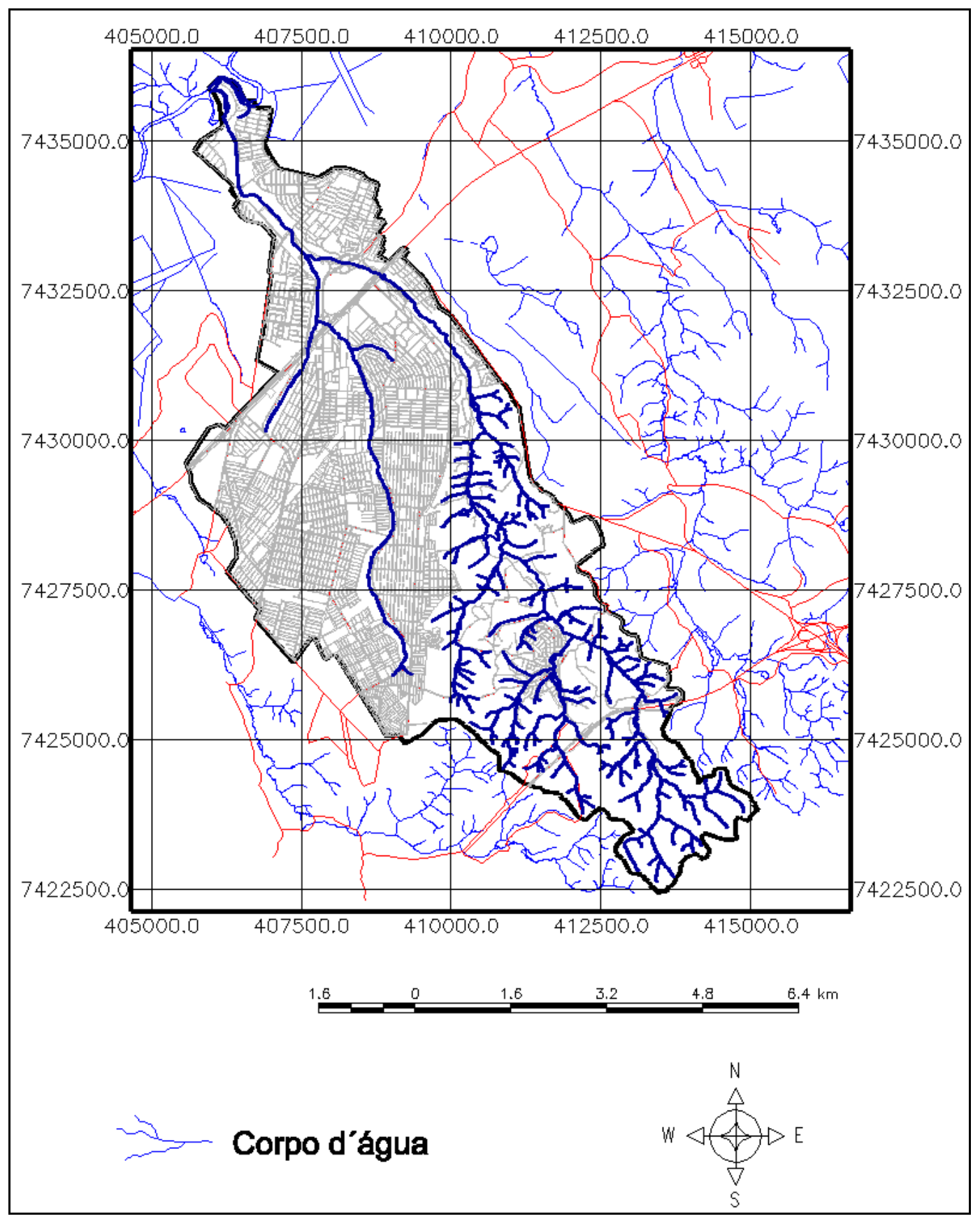

Figura 2. Bacia do Ribeirão Vidoca, visão panorâmica.

Fonte: Prefeitura Municipal de São José dos Campos (2003). 


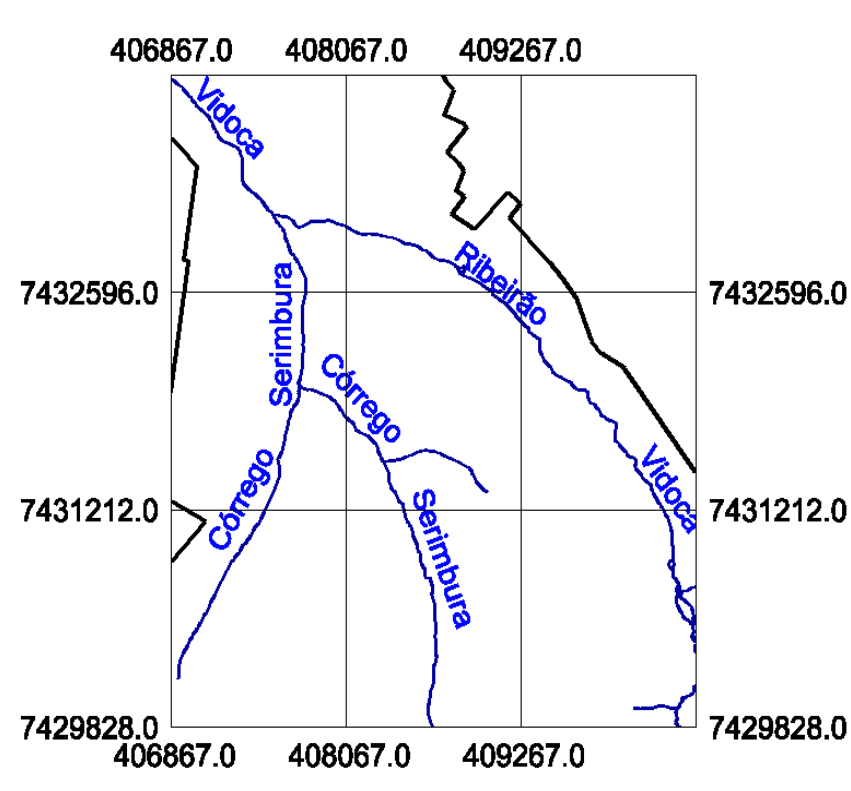

(a)

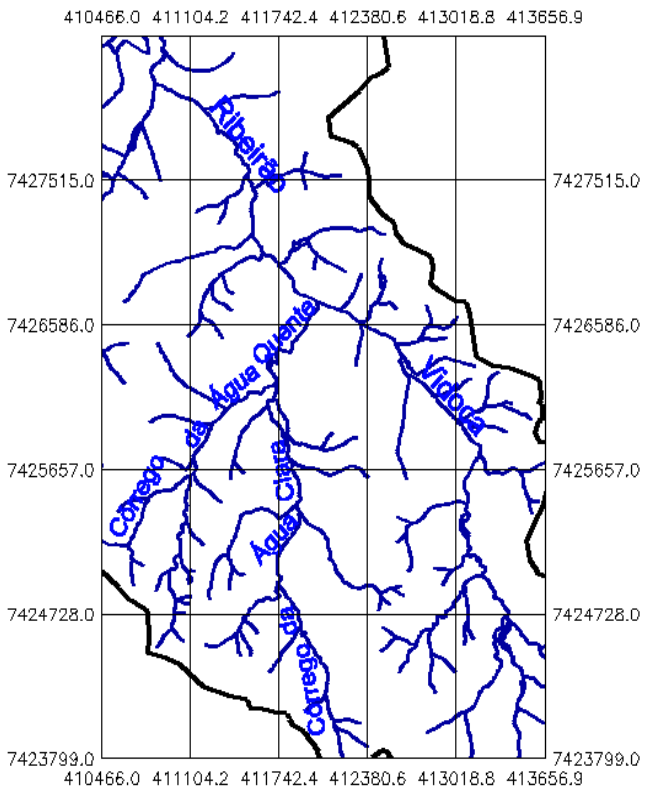

(b)

Figura 3. (a) Parte baixa da Bacia do Ribeirão Vidoca com seus cursos da água denominados; (b) Parte alta da Bacia do Ribeirão Vidoca com seus cursos da água denominados.

Fonte: Prefeitura municipal de São José dos Campos (2003).

A microbacia do Vidoca, na parte que corta as áreas ocupadas pelos bairros Colinas, Residencial Esplanada do Sol, Vale dos Pinheiros e Esplanada, encontra-se altamente urbanizada, desde a década de 90, e com sua área de várzeas ocupada por avenidas, edifícios e residências (São Paulo, 1992). A Figura 4 mostra que em 1500, a bacia do Vidoca

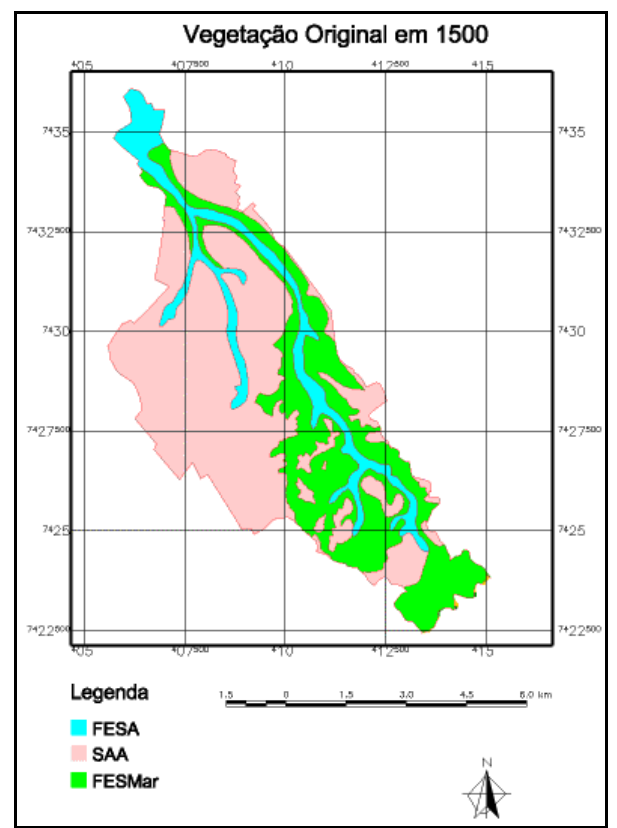

Figura 4. Vegetação original em 1.500.

Obs.: FESA = Floresta Estacional Semidecidual Aluvial; SAA = Savana Arbórea Aberta; e FESMar = Floresta Estacional Semidecidual Montana dos Morros da Serra do Mar. Fonte: Morelli (2002). 
apresentava três classes de cobertura vegetal natural, quando então predominava a Savana Arbórea Aberta (SAA), com 55\% da superfície da bacia, Floresta Estacional Semidecidual Montana dos Morros da Serra do Mar (FESMar) com 32\% e Floresta Estacional Semidecidual Aluvial (FESA), ocupando os outros 13\% do total (Morelli, 2002).

Segundo o IBGE (1986), essa composição encontrava-se distribuída na bacia. A FESA ocupava a várzea do Vidoca e de seus afluentes a 650m de altitude aproximadamente; os terraços ao longo da drenagem apareciam envolvidos pela FESMar, acima da FESA, chegando aos morros da serra do Mar, formando uma área de transição entre a FESA e a SAA que estava compreendida nas colinas tabuliformes e era de alta representatividade na época (Morelli, 2002).

O cruzamento da Carta Pedológica com a Carta de Declividade permitiu a geração da Carta Geotécnica (Figura 5). Com base nessa carta, podem-se determinar as áreas mais adequadas a um tipo específico de ocupação.

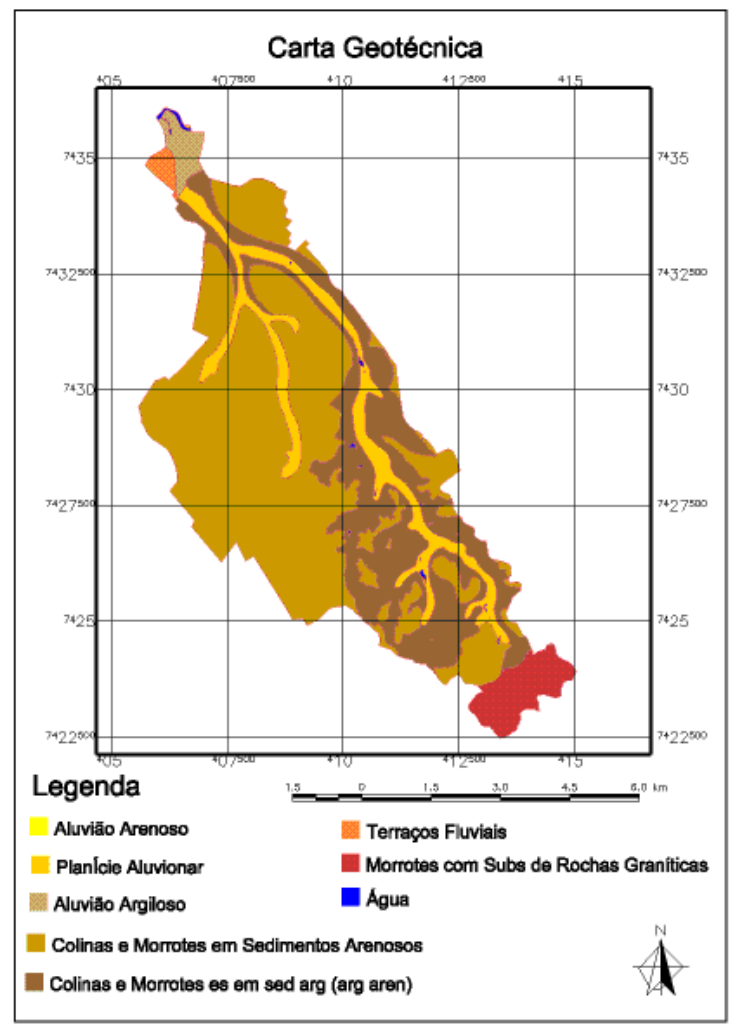

Figura 5. Carta Geotécnica da bacia do Vidoca.

Fonte: Extraída e adaptada do CD CIDADE VIVA (PMSJC, 2003).

Este trabalho envolveu o estudo de vários períodos entre 1500 e 2003: a) de 1500 a 1953; b) de 1954 a 1985; c) de 1986 a 1997; d) de 1998 a 2003. A Figura 6 apresenta o fluxograma da metodologia utilizada no desenvolvimento do trabalho.

Para realizar esta pesquisa foram empregados os seguintes materiais e equipamentos: máquina fotográfica digital; microcomputador Athlon $1.100 \mathrm{MHz}$; equipado com o Sistema de Processamento de Imagens Georreferenciadas (SPRING) (Câmara et al., 1996); Plotter; receptor GPS Garmin (modelo GPS II) e bússola. 


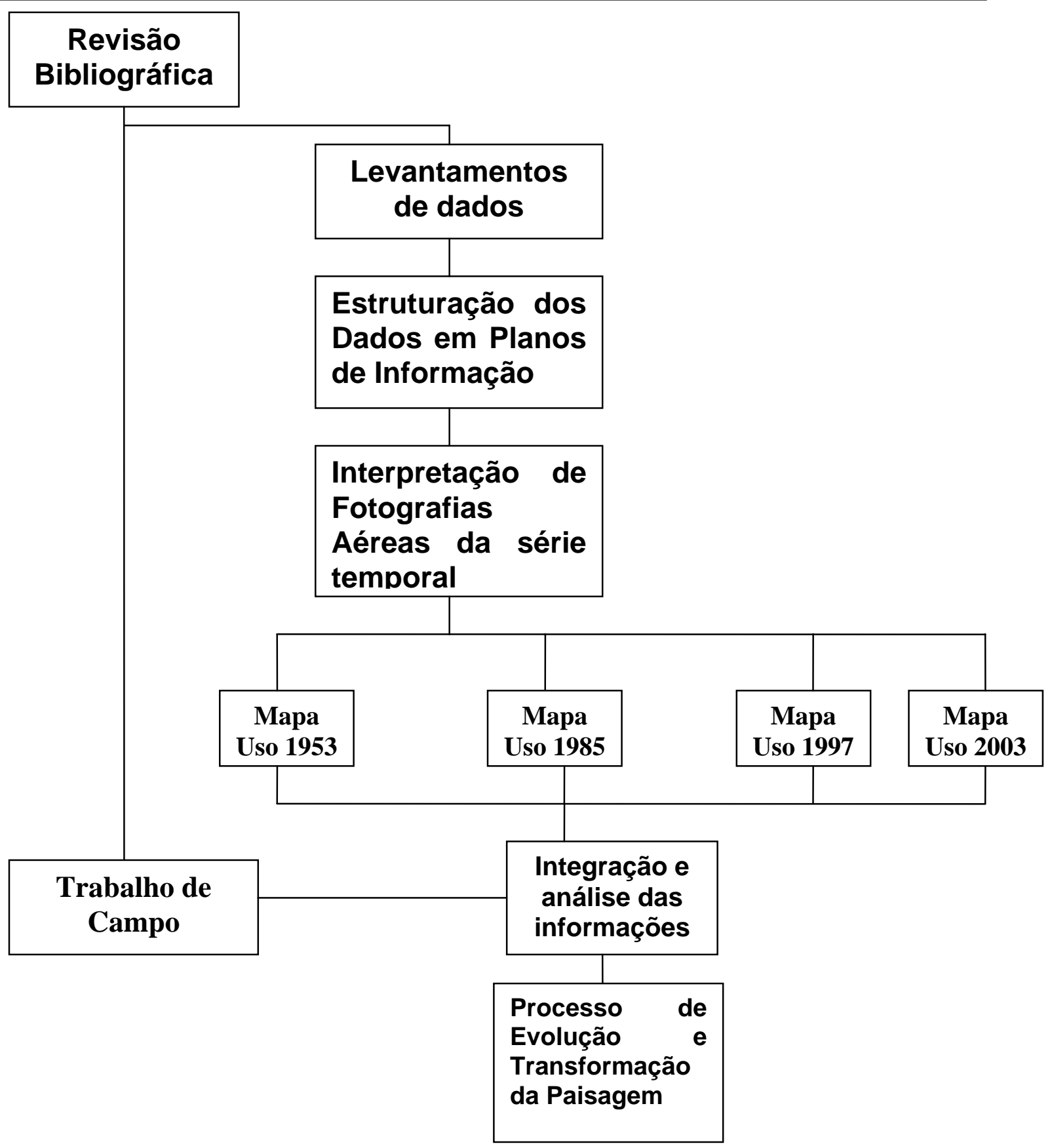

Figura 6. Fluxograma da pesquisa.

\subsection{Dados cartográficos e imagens utilizadas}

Foi realizado um levantamento de dados junto à Prefeitura Municipal de São José dos Campos para o estabelecimento da base cartográfica para o trabalho. A primeira grande fonte de dados identificada foi o CD Cidade Viva (PMSJC, 2003) que contém material cartográfico digital no formato SPRING com dados planimétricos e altimétricos do município de São José dos Campos, SP. Os dados planimétricos, na forma vetorial, incluem: sistema viário, drenagem, classes de uso das terras e classes de unidades territoriais. Os dados altimétricos referem-se ao Modelo Numérico do Terreno (MNT), com curvas de nível a cada 5m. A Prefeitura de São José dos Campos disponibilizou também a base cartográfica digitalizada de todo o município com base no Plano Cartográfico do Estado de São Paulo, escala 1:10.000 (IGC, 1978), fotos aéreas digitais de 1997 e 2003 para o trabalho, assim como, a carta 
geotécnica e o limite da bacia que também não constavam no CD Cidade Viva (2003). Do Atlas Ambiental de São José dos Campos (Morelli et al., 2005) foram extraídas a carta de vegetação original do ano de 1500, na escala 1:10.000. As cartas foram recortadas para o limite da bacia usando-se funções do SPRING (Câmara et al., 1996).

Foram utilizadas fotos aéreas de 1953 (mosaico aerofotogramétrico) e de 1985 obtidas junto ao Departamento de Águas e Energia Elétrica do Estado de São Paulo (DAEE). As fotos aéreas de 1953 e de 1985 foram adquiridas em papel e, posteriormente, digitalizadas por meio de um scanner na resolução de $5 \mathrm{~m}$ (1953) e de $2 \mathrm{~m}$ (1985), respectivamente, disponibilizadas no Atlas Ambiental de São José dos Campos (Morelli et al., 2005). Para o ano de 1997 e 2003, foram utilizadas as ortofotos fornecidas pela Prefeitura Municipal de São José dos Campos com resoluções de $0,25 \mathrm{~m}$ e $0,40 \mathrm{~cm}$, respectivamente.

\subsection{Interpretação da série temporal de fotografias aéreas}

As fotografias em formato digital foram interpretadas usando o sistema de processamento de imagens SPRING 4.1 (Câmara et al., 1996). Esse processo iniciou-se com o registro das fotos de 1953 e de 1985 e, em seguida, foram incorporadas no banco de dados as ortofotos de 1997 e 2003. Após a definição da legenda das classes de uso da terra, extraiu-se informação dos dados do ano de 1997, devido à sua melhor resolução espacial, e, a seguir, foi realizada a interpretação das demais séries temporais de dados, com base nos princípios da interpretação visual, diretamente na tela do computador.

\subsection{Análise da transformação da paisagem}

A análise da transformação da paisagem foi facilitada pelo uso do SPRING por meio do qual foi possível a geração de tabelas com as áreas de cada classe mapeada, em cada ano analisado, que foram exportadas para uma planilha Excel para permitir o cálculo da percentagem de ocorrência de cada classe em relação ao total da bacia. Além da geração de tabelas com dados de cada ano estudado, foram feitos cruzamentos dos mapas por períodos para se avaliar a transformação da paisagem de um ano para o outro: 1500-1953; 1953-1985; 1985-1997; 1997-2003, utilizando-se a função "tabulação cruzada” do SPRING (Câmara et al., 1996). Assim, uma classe que existia em 1500 pode ter se transformado em outras classes em 1953, e, assim por diante até 2003.

\subsection{Verificação de Campo}

A verificação de campo foi realizada para esclarecer possíveis dúvidas sobre a identidade das classes do mapeamento na interpretação do material de sensoriamento remoto (fotos aéreas). O trabalho de campo foi planejado com base nas cartas nas quais foram demarcados os pontos a serem visitados. O receptor GPS (Sistema Global de Posicionamento) e a bússola serviram para orientação em campo, respectivamente, na localização dos pontos e na medida das direções a serem seguidas.

O trabalho de campo deste trabalho foi concomitante à elaboração do Atlas Ambiental de São José dos Campos, SP (Morelli et al., 2005), projeto desenvolvido por uma equipe multidisciplinar que caracterizou a paisagem desse município. O trabalho de campo foi realizado no período de 2003 a 2005 e precedeu a geração dos mapas aqui apresentados.

\section{RESULTADOS}

A análise temporal forneceu uma idéia do processo, ou seja, um resumo histórico da paisagem em diferentes momentos. Porém, o cruzamento das informações permitiu a análise 
STEMPNIAK, A.; BATISTA, G. T.; MORELLI, A. F. Avaliação da transformação da paisagem na bacia do ribeirão Vidoca, São José dos Campos, SP, Brasil. Ambi-Agua, Taubaté, v. 2, n. 3, p. 83-97, 2007. (doi:10.4136/ambi-agua.35)

quantitativa do quanto e o quê foi alterado, o que pode ensejar projeções de conseqüências, ainda que parciais.

Os temas mapeados foram: paisagem natural (cobertura vegetal) e paisagem antrópica (espaço urbano e vegetações alteradas pelas atividades agropastoril) (Figura 7).

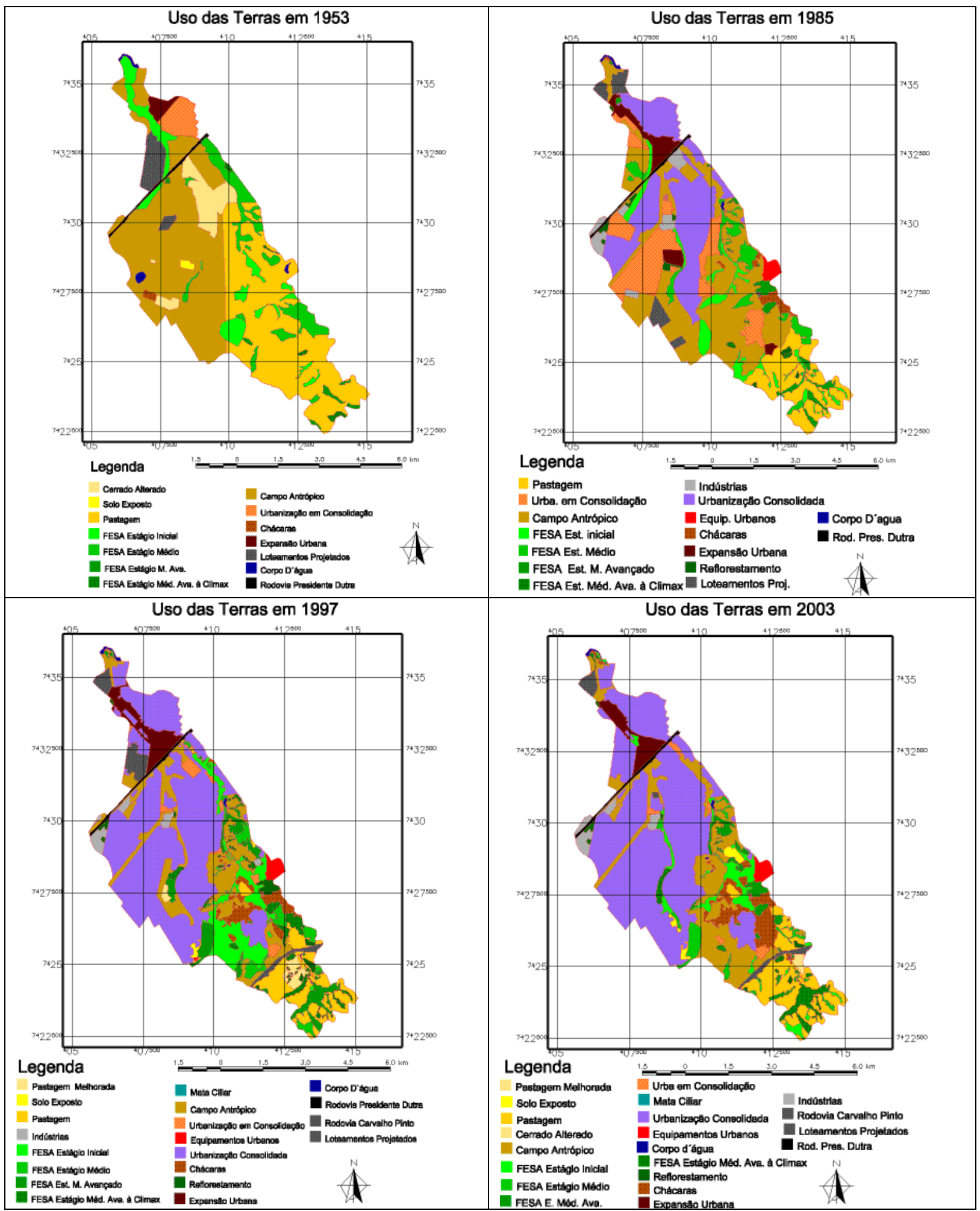

Figura 7. Mapas de uso e cobertura da terra para os anos de 1953, 1985, 1997 e 2003, resultantes da interpretação de fotos aéreas. 
A foto-interpretação de material digital, diretamente no computador, tem a vantagem de permitir o realce de detalhes pela facilidade de se mudar a escala, em função da resolução da imagem ou dimensão dos objetos a serem delineados.

\subsection{Transformação da Vegetação Original 1500 a 1953}

Em 1500, havia três classes de vegetação original na Bacia do Ribeirão Vidoca (Tabela 1): Savana Arbórea Aberta (SAA), Floresta Estacional Semidecidual de Morretes e Morrotes e da Serra do Mar (FESMar) e Floresta Estacional Semidecidual Aluvial (FESA). Esses domínios ocupavam 2712,8ha, 1552,9ha e 634,1ha, respectivamente. A SAA era um domínio situado originalmente sobre as colinas tabuliformes, a FESMar se localizava nas encostas dessas colinas que, em suas partes mais baixas, continha a FESA, situada nos vales próxima aos corpos da água.

Tabela 1. Classes de cobertura vegetal original nos anos de 1500 e 1953 na bacia do Vidoca.

\begin{tabular}{l|ccc}
\hline Classes de Uso do Solo & $\mathbf{1 5 0 0}$ (ha) & $\mathbf{1 9 5 3}$ (ha) & Remanescente (\%) \\
\hline SAA & 2712,8 & 246,1 & 9,1 \\
FESMar & 1552,9 & 358,9 & 23,1 \\
FESA & 634,1 & 230,5 & 36,3 \\
\hline
\end{tabular}

Com a ação antrópica, as áreas dessas coberturas florestais foram reduzidas e pouco sobrou da cobertura original, especialmente da SAA que embora tivesse a maior ocorrência foi a mais alterada, sobrou apenas 9,1\%. Mesmo esse remanescente de SAA apresentava-se alterado. De forma similar, apenas 23,1\% da FESMar e 36,3\% da FESA restaram de suas áreas originais.

Com a alteração das classes de vegetação original surgiram novas classes de uso da Terra: Campo Antrópico, Pastagem, Loteamentos Projetados, Urbanização em Consolidação, Expansão Urbana, Rodovia Presidente Dutra (Tabela 2). A classe mais representativa no ano de 1953 foi Campo Antrópico com 1869,9ha, seguida por Pastagem com 1558,8ha. As demais classes relacionadas à urbanização (Loteamentos Projetados, Urbanização em Consolidação, Expansão Urbana e a Rodovia Presidente Dutra) somam 389,2ha no total.

Tabela 2. Classes resultantes da ocupação antrópica nas coberturas vegetais originais observadas no ano de 1953 na bacia do Vidoca.

\begin{tabular}{l|rrrr}
\hline Classes & SAA & FESMar & FESA & Total \\
\hline Campo Antrópico & 1527,8 & 122,5 & 219,5 & 1869,9 \\
Pastagem & 380,3 & 1021,8 & 156,7 & 1558,8 \\
Loteamentos Projetados & 136,7 & 15,7 & 0 & 152,4 \\
Urbanização em Consolidação & 131,5 & 12,3 & 0 & 143,8 \\
Expansão Urbana & 45,9 & 7,2 & 0 & 53,0 \\
Rodovia Presidente Dutra & 30,7 & 4,17 & 5,3 & 40,0 \\
\hline
\end{tabular}

O Campo Antrópico caracterizado como pastagem abandonada, passou a ser objeto de especulação imobiliária e ocupou boa parte da SAA e também áreas de FESMar e FESA. Essa classe se desenvolveu primeiramente nas colinas tabuliformes onde predominava a SAA. Já as pastagens, inicialmente, foram implantadas nas regiões onde ocorriam FESA e FESMar e, posteriormente, ocuparam as colinas tabuliformes. O processo de urbanização ocorreu nessas 
STEMPNIAK, A.; BATISTA, G. T.; MORELLI, A. F. Avaliação da transformação da paisagem na bacia do ribeirão Vidoca, São José dos Campos, SP, Brasil. Ambi-Agua, Taubaté, v. 2, n. 3, p. 83-97, 2007. (doi:10.4136/ambi-agua.35)

pastagens quando foram abandonadas e transformadas em Campo Antrópico. A Tabela 3 mostra a mudança de uso e cobertura do solo de 1953 a 2003.

Tabela 3. Classes de ocupação antrópica e de coberturas vegetais originais (FESA e FESMar) observadas no período de 1953 a 2003 na bacia do Vidoca.

\begin{tabular}{|c|c|c|c|c|c|c|c|c|}
\hline \multirow{3}{*}{ Classes } & \multicolumn{8}{|c|}{ Ano } \\
\hline & \multicolumn{2}{|c|}{1953} & \multicolumn{2}{|c|}{1985} & \multicolumn{2}{|c|}{1997} & \multicolumn{2}{|c|}{2003} \\
\hline & Área (ha) & $\%$ & Área (ha) & $\%$ & Área (ha) & $\%$ & Área (ha) & $\%$ \\
\hline Campo Antrópico & 1869,9 & 38,1 & 1398,3 & 28,5 & 667,1 & 13,6 & 780,1 & 15,9 \\
\hline Pastagem & 1558,8 & 31,8 & 455,7 & 9,3 & 349,8 & 7,1 & 421,7 & 8,6 \\
\hline Loteamentos Projetados & 152,4 & 3,1 & 129,4 & 2,6 & 106,9 & 2,2 & 40,5 & 0,8 \\
\hline Urbanização em Consolidação & 143,8 & 2,9 & 570,5 & 11,6 & 41,3 & 0,8 & 41,3 & 0,8 \\
\hline Expansão Urbana & 53,0 & 1,1 & 192,7 & 3,9 & 134,0 & 2,7 & 134,0 & 2,7 \\
\hline Urbanização Consolidada & 0,0 & $\mathbf{0 , 0}$ & 1048,8 & 21,4 & 2117,3 & 43,1 & 2347,6 & 47,8 \\
\hline FESA + FESMar & 589,3 & 12,0 & 667,8 & 13,6 & 953,0 & 19,4 & 780,1 & 15,9 \\
\hline
\end{tabular}

\subsection{Transformação da cobertura do solo de 1953 a 1985}

A análise comparativa dos anos 1953 e 1985 evidencia o processo de urbanização das classes Campo Antrópico e Pastagem situadas nas colinas tabuliformes, encostas e vales (Tabela 3). Dessa forma, a classe Campo Antrópico ocupava 38,1\% da bacia e passou a ocupar em 1985, 28,5\% da área total, isso acontece com Pastagem com uma queda ainda mais abrupta de 31,8\% para 9,3\%, cedendo espaço para o crescimento das classes relacionadas com crescimento urbano como Urbanização em Consolidação de 2,9\% para 11,6\%, Expansão Urbana com 1,1\% para 3,9\%, e, principalmente, Urbanização Consolidada que, em 1953, não apresentava área mensurável e passou a ocupar 21,4\% da bacia em 1985.

Esse crescimento pode ser atribuído à mudança do modelo econômico do Brasil, que na primeira metade do século XX era agrário e passou a ser rural na segunda metade daquele século (Sene; Moreira, 1998), assim, várias cidades cresceram sem planejamento e as atividades agrárias foram substituídas pelas industriais, antigas áreas de atividades agropastoris tornaram-se Campo Antrópico e logo se converteram em áreas urbanas (Silva, 2005). O perfil de ocupação revela uma situação em que, inicialmente, as colinas tabuliformes foram urbanizadas até seus limites, posteriormente, o processo de urbanização desceu as encostas até a várzea.

Um aspecto positivo é que a FESA e a FESMar se regeneraram nas áreas próximas às nascentes ao sul da Rodovia Carvalho Pinto.

\subsection{Transformação da cobertura do solo de 1985 a 1997}

De 1985 a 1997 continuou o decréscimo da classe Campo Antrópico em função do avanço da urbanização como pode ser verificado na Tabela 3. A área dessa classe foi reduzida em praticamente 50\%, em 1985 ocupava 28,5\% e, em 1997, passou a ocupar apenas 13,6\% da área total da bacia. Outro dado que evidencia o processo de urbanização é a diminuição da área ocupada por Pastagem que passou de 9,3\% em 1985 para 7,1\% da área da bacia em 1997. Observou-se que essa classe foi transformada principalmente para Campo Antrópico. Parte da pastagem também foi convertida diretamente para classes de urbanização e uma pequena parte foi abandonada e se regenerou para FESA.

Com base nos dados da Tabela 3, fica evidente que o processo de urbanização esteve se consolidando nesse período. Enquanto a classe de Urbanização em Consolidação cai de 11,6\% para 0,8\%, a classe Urbanização Consolidada aumenta de 21,4\% para 43,1\% mais que 
dobrando sua área nesse período. De forma similar, a área ocupada pelas classes Expansão Urbana e Loteamentos Projetados diminuem, pois há consolidação da urbanização na bacia.

\subsection{Transformação da cobertura do solo de 1997 a 2003}

As ocorrências das classes Pastagem e Campo Antrópico se estabilizaram com pouca variação (13,6\% para 15,9\%) e (7,1\% para 8,6\%), respectivamente (Tabela 3). Literalmente não houve mudança mensurável nas classes de Urbanização em Consolidação e Expansão Urbana nesse período. A principal mudança foi o crescimento urbano, consolidando a ocupação dos vales, revelado pelo aumento da área ocupada com a classe Urbanização Consolidada de 43,1\% para 47,8\% da área total da bacia.

Esse aumento na ocupação urbana ocasionou a perda da FESA que vinha, no passado, recuperando-se nos vales entre as colinas tabuliformes. A Tabela 3 mostra ainda que em 1997 essa classe ocupava 19,4\% e passou a ocupar apenas 15,9\% (FESA + FESMar) da área total da bacia, em 2003. A supressão da vegetação nos vales ocorreu em Áreas de Proteção Permanente (APP). Essas áreas abrigavam matas ciliares importantes para a proteção das margens dos corpos da água.

\section{DISCUSSÃO DOS RESULTADOS}

A transformação da paisagem na bacia do Ribeirão Vidoca é resultante da mudança do perfil econômico no século XX que ocorreu no Brasil e refletiu no município de São José dos Campos, SP. A passagem de uma economia agrária para uma industrial levou ao crescimento gradual das cidades, sem planejamento. A paisagem retrata o histórico natural e antrópico ao longo do tempo. Na primeira, as transformações são lentas, na segunda as transformações são mais rápidas, às vezes chegando a poucos anos. A capacidade tecnológica do homem interferir no meio natural torna-se um grande modelador do espaço. Ao retificar a drenagem ou ao suprimir a vegetação de mata ciliar, perde-se patrimônio natural relacionado com a sustentabilidade dos recursos hídricos.

A Figura 8 mostra o crescimento da população de São José dos Campos no período de 1940 a 2007 (IBGE, 2007).

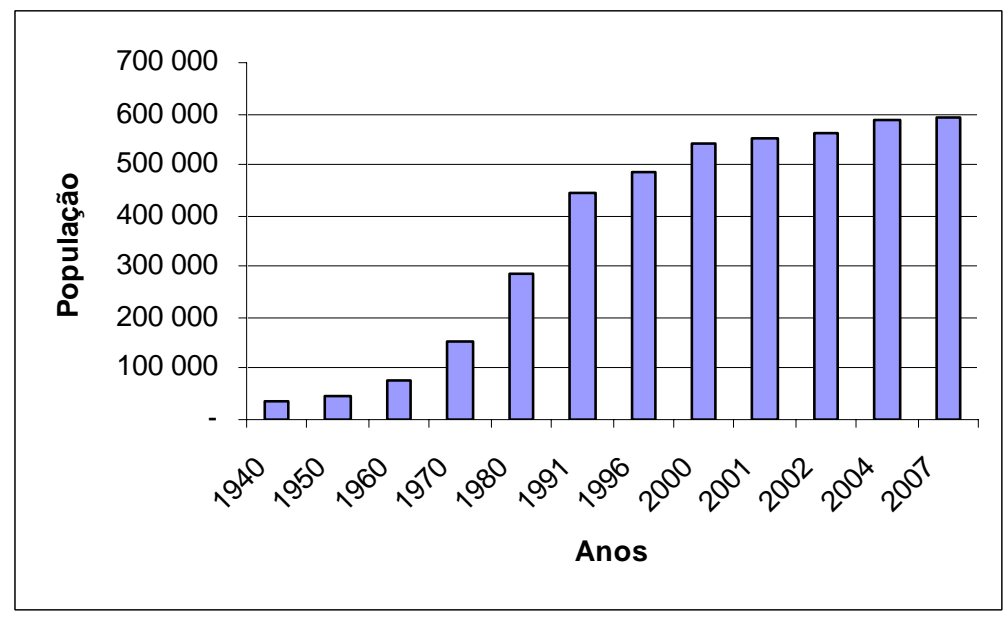

Figura 8. População de São José dos Campos de 1940 a 2007. Fonte: adaptado dos Censos Demográficos e Projeções 2007 (1940, 1950, 1960, 1980, 1991, 2000 e 2007) (IBGE, 2007). 
Pode ser verificado que a população cresceu mais de 20 vezes nesse período. Esse crescimento se reflete no crescimento das áreas urbanizadas, grandemente influenciado pela Rodovia Presidente Dutra que corta a bacia estudada.

O cenário em 1500 mostrava uma fisionomia homogênea da vegetação, a interferência humana foi decisiva na mudança da paisagem da bacia do Vidoca ao longo do período estudado como foi demonstrado neste trabalho. Havia apenas três classes de cobertura vegetal: Savana Arbórea Aberta (SAA), Floreta Estacional Semidecidual de Morretes e Morrotes e da Serra do Mar (FESMar) e Floresta Estacional Semidecidual Aluvial (FESA). Esses domínios de vegetação compreendiam um sistema integrado sendo difícil a distinção entre eles; há enclaves de FESA dentro do domínio do cerrado e a FESMar situada nas encostas entre FESA e SAA pode ser considerada uma transição entre a FESA e a SAA.

No período inicial do estudo, a economia agrária foi responsável pelo aumento das áreas de pastagens, transformando todos os domínios, sendo o mais atingido a SAA, depois a FESMar e por último a FESA. Deve-se ressaltar que a Savana inicialmente tinha uma área maior e era localizada nas colinas tabuliformes, local propício à ocupação. Contudo, com a ocupação urbana, áreas de floresta aluvial, responsáveis pela proteção dos corpos da água foram também ocupadas. Dessa forma, a suspensão da vegetação próxima aos corpos da água pode estar associada à degradação dos recursos hídricos e a perda do patrimônio ambiental quando se considera a flora, fauna e beleza cênica.

Valério Filho et al. (2005), discutindo drenagem urbana do Município de São José dos Campos, apontaram a bacia do Vidoca como a segunda de maior índice de impermeabilização global $(0,37)$ entre todas as bacias estudadas e indicam a urbanização consolidada (aproximadamente $50 \%$ da área da bacia) como causa dessa impermeabilização. Indicam ainda que a leste dessa bacia, a classe área não consolidada com baixa taxa de ocupação ocorre com maior frequiência, indicando a possibilidade de adensamento no futuro. Além disso, ocorrem extensas áreas de pastagem, que indicam possibilidade de expansão urbana e, portanto, alertam para a necessidade de maior atenção por parte do poder público.

\section{CONCLUSÕES}

As atividades antrópicas que mais alteraram a paisagem da bacia do Vidoca foram o estabelecimento de campos antrópicos, pastagens, urbanização em consolidação e urbanização consolidada e a abertura da Rodovia Presidente Dutra e, mais recentemente, da Rodovia Carvalho Pinto. As rodovias, especialmente a Dutra, foram indutoras do crescimento urbano e influenciaram o processo da ocupação urbana na bacia do Vidoca.

De 1500 a 1953 foram implantadas áreas de pastagens e se materializou uma grande área com campo antrópico. O processo de urbanização iniciou-se principalmente com a abertura e duplicação da rodovia Presidente Dutra que se constituiu em marco simbólico do começo da passagem da economia agrária para industrial nessa região que passou de características rurais para urbanas.

No período seguinte de 1954 até 1985 ocorreu a ocupação das colinas tabuliformes, com a urbanização se estendendo até as bordas do tabuleiro fazendo com que áreas de pastagens se transformassem em campos antrópicos. A FESA e a FESMar começaram a se regenerar na parte alta da bacia. Nesse período, a FESA ainda aparecia com representatividade nos vales entre as colinas.

De 1986 a 1997, a urbanização se consolidou, houve ocupação das várzeas (vales), e, em conseqüência, a supressão da vegetação (FESA), a urbanização desceu até as encostas das colinas e chegou próximo aos corpos da água. A regeneração da FESA resultou em pequenos fragmentos entre pastagens e chácaras. 
No Período de 1998 a 2003, houve um pequeno crescimento urbano, porém uma significativa consolidação da urbanização. Embora, em termos de área ocupada, a FESA tenha diminuído, houve pequenas áreas de regeneração dessa classe localizadas nos vales e na parte alta da bacia, próximo às nascentes.

\section{REFERÊNCIAS}

CÂMARA, G.; SOUZA, R. C.; FREITAS, U. SPRING: integrating remote sensing and GIS with object oriented data modelling. Computers and Graphics, Dordrecht, v. 15, n. 6, p. 13-22, 1996.

COELHO NETTO, A. L. C. Hidrologia de encosta na interface com a Geomorfologia. In: GUERRA, A. J. T.; CUNHA, S. B. da. Geomorfologia: uma atualização de bases e conceitos. 2. ed. Rio de Janeiro: Bertrand Brasil, 1995. p. 93-148.

COMITÊ PARA INTEGRAÇÃO DA BACIA HIDROGRÁFICA DO RIO PARAÍBA DO SUL (CEIVAP), 2000. Projeto preparatório para o gerenciamento dos recursos hídricos do Paraíba do Sul. Disponível em: <http://www.ceivap.org.br /estudos/download/ppg/PPG-RE-23.pdf> Acesso em: 24 fev. 2006.

CASIMIRO, P. C. Geografia, ecologia da paisagem e teledetecção, enquadramento contextualização. Revista da Faculdade de Letras do Porto, Geografia I Série, v. 19, p. 467-476, 2004.

INSTITUTO BRASILEIRO DE GEOGRAFIA E ESTATÍSTICA. Censo demográfico do Brasil e contagem da população 2007. Rio de Janeiro: IBGE: 2007. Disponível em: < http://www.ibge.gov.br/home/estatistica/populacao>. Acesso em: 28 nov. 2007.

INSTITUTO BRASILEIRO DE GEOGRAFIA E ESTATÍSTICA. Mapa de vegetação do Brasil. Rio de Janeiro: IBGE, 1986.

INSTITUTO GEOGRÁFICO E CARTOGRÁFICO DO ESTADO DE SÃO PAULO - IGC. Cartas topográficas do plano do Estado de São Paulo do município de São José dos Campos. São Paulo: IGC, 1978. Escala: 1:10.000.

MORELLI, A. F. Identificação e transformação das unidades da paisagem no município de São José dos Campos, de 1500 a 2000. 2002. Tese (Doutorado em Geociências e Meio Ambiente) - UNESP, Rio Claro, 2002. p.120-121.

MORELli, A. F.; FANTIN, M.; ALVES, M., STEMPNIAK, A. Atlas ambiental de São José dos Campos: versão preliminar. São José dos Campos: Fundação Cultural Cassiano Ricardo, 2005. 1 CD-ROM (no prelo).

PREFEITURA MUNICIPAL DE SÃO JOSÉ DOS CAMPOS. Cidade viva de São José dos Campos. São José dos Campos: Prefeitura municipal, 2003. 1 CD-ROM.

ROSS, J. (org.). Geografia do Brasil. São Paulo: EDUSP, 1995. p.115-117.

SÃO PAULO. Departamento de águas e energia elétrica. Secretaria de saneamento e energia. SEMANA DE DEBATES SOBRE RECURSOS HÍDRICOS E MEIO AMBIENTE, 4 a 6 de maio de 1992, Piracicaba. Atas... Piracicaba: DAEE, 1992. 
SENE, E. de, MOREIRA, J. C. A urbanização brasileira. In: Geografia Geral e do Brasil São Paulo: Scipione, 1998. p. 321-326. Cap. 4.

SILVA, D. F. Crescimento e desequilíbrio regional no Vale do Paraíba: uma abordagem das disparidades econômicas e tecnológicas. 2005, 145f. Dissertação (Mestrado em Gestão e Desenvolvimento Regional) - Universidade de Taubaté, Taubaté, 2005.

VALÉRIO FILHO, M.; OLIVEIRA KURKDJIAN, M. de L. N.; NIERO P, M.; ALVES, M. de Geotecnologias aplicadas ao estudo de bacias hidrográficas urbanizadas como subsídios ao plano diretor de drenagem. In: SIMPÓSIO BRASILEIRO DE SENSORIAMENTO REMOTO, 12., 16-21 abril 2005, Goiânia. Anais... São José dos Campos: INPE, 2005. p. 3919-3926. 


\begin{tabular}{|c|} 
ISSN = 1980-993X - doi:10.4136/1980-993X \\
www.agro.unitau.br/ambi-agua \\
E-mail: ambi-agua@agro.unitau.br \\
Tel.: (12) 3625-4116
\end{tabular}

\title{
Controle qualitativo e quantitativo do escoamento pluvial urbano com bacias de detenção \\ (doi:10.4136/ambi-agua.36)
}

\section{Néstor Aldo Campana; Ricardo Silveira Bernardes; Jolival Antonio da Silva Jr.}

\author{
Departamento de Engenharia Civil e Ambiental - ENC \\ Faculdade de Tecnologia - FT. Universidade de Brasília - UnB \\ Campus Universitário Darcy Ribeiro - Asa Norte - Brasília/DF - CEP 70.910-900 \\ E-mail: mnestor@unb.br; ricardo@unb.br; jolivaljr@gmail.com
}

\section{RESUMO}

As cheias urbanas são responsáveis por transtornos que vão desde pequenos empoçamentos a enormes prejuízos materiais e à saúde humana. Com o intuito de minimizar o efeito das enchentes em áreas urbanas, várias metodologias vêm sendo estudadas. Dentre elas, as bacias de detenção e retenção são bastante utilizadas em áreas com urbanização consolidada. Neste estudo apresenta-se uma análise da eficiência de duas bacias de detenção uma seca e outra alagada - no controle de inundações abordando os aspectos quantitativo e qualitativo do escoamento proveniente da rede de drenagem pluvial da cidade de Brasília DF, Brasil. O afluente para as bacias de detenção é proveniente de sistema convencional de drenagem urbana com $4,75 \mathrm{~km}^{2}$ (bacia seca) e $6,12 \mathrm{~km}^{2}$ (bacia alagada) de área de contribuição. Os resultados mostraram a eficiência dos dispositivos monitorados na redução das vazões de pico, redução média observada de 62,6\% e 74\%, para a bacia de detenção seca e alagada, respectivamente. Além disso, essas estruturas reduzem as concentrações de alguns poluentes encontrados nas águas pluviais despejadas nas referidas bacias de detenção, com valores médios de remoção variando na faixa de 1 a 3\% para DBO até a faixa de 41 a $74 \%$ para Sólidos Suspensos.

Palavras-chave: detenção; cheias; drenagem urbana.

\section{Qualitative and quantitative control of the urban runoff with detention basins}

\begin{abstract}
Floods in urban areas are responsible for impacts that go from puddles formation to environmental and social disasters. Looking for alternatives to minimize the effects of floods in urban areas, some methodologies have been studied and applied, such as the use of detention basin in high consolidated urban areas. This study analyses the efficiency on flood control of two detention basins, a dry and a wet one. The study approaches both quantitative and qualitative aspects related to runoff from an urban area of Brasilia city, federal district of Brazil. The affluent caught by the detention basins is related to a conventional urban drainage system with a $4.75 \mathrm{~km}^{2}$ (dry basin) and $6.12 \mathrm{~km}^{2}$ (wet basin) contribution area. The results showed that the basins can reduce the peak income flow significantly (averaged $62.6 \%$ and $74 \%$ peak flow reduction, for dry and wet basin, respectively) and has positive impact over pollution control, with an average reduction of 1 to $3 \%$ for BOD and up to 41 to $74 \%$ for Suspended Solids.
\end{abstract}

Keywords: Detention basin; wet pond; urban runoff. 


\section{INTRODUÇÃO}

Com o aumento das áreas impermeáveis nas cidades, o aumento progressivo de eventos de inundações e a ineficiência dos dispositivos inseridos para a condução do escoamento proveniente das chuvas em áreas urbanas têm mostrado ao meio técnico um cenário preocupante. Desde essa constatação, dia-a-dia têm-se buscado novas alternativas para o controle das cheias em áreas urbanas.

Os incrementos nas vazões decorrentes das chuvas em áreas urbanas vêm sendo objeto de estudo de inúmeras pesquisas. Num primeiro momento, a quantificação dos acréscimos observados por simulação se tornou uma ferramenta de grande utilidade para a adoção de medidas que auxiliem no controle desses acréscimos evitando, assim, a ocorrência de inundações. No entanto, é de suma importância a validação dos resultados obtidos com observações in loco.

Uma outra preocupação diz respeito ao aspecto qualitativo das águas pluviais. Quando da ocorrência de eventos de inundação, a constatação da contaminação da população sujeita ao contato com as águas de chuva também mostrou claramente a necessidade de se investigar os tipos de compostos carreados pelas águas pluviais nas ruas e córregos urbanos. Levando-se em conta o sistema separador absoluto adotado pela grande maioria das cidades brasileiras, a detecção de despejos domésticos clandestinos na rede de drenagem obriga a administração local a fazer o tratamento antes da descarga nos rios, das águas pluviais urbanas.

Uma das medidas mais difundidas para o controle de inundações no período higienista foi a canalização de córregos urbanos, que com o tempo, mostrou-se ineficiente no sentido de conter as cheias na sua totalidade, pois esse dispositivo apenas transfere os efeitos das cheias urbanas para jusante, conforme cita Canholi (2005).

Conforme Silva (2006), desde o início da década dos anos 90 surgiu no Brasil um novo paradigma para a drenagem urbana o qual abandona o conceito tradicional de drenagem que consistia em retirar o excedente superficial o mais rápido possível da bacia hidrográfica, para se adotar um modelo compensatório que não permite a propagação do excedente superficial para jusante, mas, sim, a permanência deste na bacia hidrográfica, obviamente em local apropriado para não gerar interferências à população.

A partir desse momento são incorporadas ao sistema de drenagem urbana as denominadas medidas compensatórias que visam ao armazenamento temporário do excedente superficial e/ou a infiltração dele, ou parte, no solo. Esse tipo de solução é conhecido também como medida estrutural, uma vez que envolve a construção de uma obra física.

Diversos pesquisadores tais como Campana e Tucci (2001), Bertoni (2004), Chocat et al. (2004), Jones et al. (2006), entre outros, citam que dentre as medidas compensatórias mais amplamente difundidas, destacam-se os dispositivos de infiltração tais como bacia e valas de infiltração e percolação, que reduzem o volume do escoamento superficial e possibilitam a recarga do lençol freático e os dispositivos de detenção e retenção tais como reservatórios abertos ou enterrados, impermeáveis ou não, que têm por objetivo o controle da vazão lançada nas galerias de águas pluviais e corpos d'água receptores.

Em áreas de ocupação muito densa, que dificultam a utilização de medidas que favorecem a infiltração que demandam espaços relativamente grandes, uma medida bastante difundida é a utilização de reservatórios ou bacias de detenção e retenção. No tocante ao aspecto hidráulico dos reservatórios, pelos estudos já desenvolvidos por simulação matemática, pode-se concluir que estes se apresentam como alternativa viável do ponto de vista da redução dos picos dos hidrogramas de cheia. 
As medidas para o controle de cheias podem assumir características preventivas ou corretivas conforme a etapa de execução delas. As medidas não estruturais, pela sua essência, possuem um caráter preventivo tanto no aspecto quantitativo quanto no aspecto qualitativo.

A convivência com a inundação por meio da utilização de sistemas de alerta e seguro contra inundação e o respeito ao zoneamento de áreas de inundação como uma forma de restringir e organizar a ocupação urbana são exemplos de medidas não estruturais. De acordo com Baptista et al. (2005), as medidas não estruturais incluem, também, o planejamento da deposição de resíduos perigosos tais como substâncias tóxicas, restos de tinta, solventes e pesticidas, os programas de prevenção e controle da erosão, varrição de ruas e disposição adequada do lixo urbano e o controle de pontos potencialmente poluidores.

As medidas estruturais, a princípio utilizadas para o controle quantitativo, também têm efeito sobre a concentração de poluentes carreados pelas águas pluviais, conforme citam Mays e Pe (2001) e Urban Drainage and Flood Control District (1991). A Tabela 1 apresenta alguns resultados divulgados pela literatura sobre a eficiência de medidas estruturais na remoção de poluentes.

Tabela 1. Eficiência das medidas estruturais na melhoria da qualidade da água.

\begin{tabular}{l|c|c|c|c|c}
\hline \multirow{2}{*}{\multicolumn{1}{c|}{ Alternativa de controle }} & \multicolumn{5}{c}{ Porcentagem de remoção } \\
\cline { 2 - 6 } & $\begin{array}{c}\text { Sólido em } \\
\text { suspensão }\end{array}$ & $\begin{array}{c}\text { Fósforo } \\
\text { Total }\end{array}$ & $\begin{array}{c}\text { Nitrogênio } \\
\text { Total }\end{array}$ & Zinco & \multirow{2}{*}{ Bactéria } \\
\hline Minimização de áreas conectadas & n.d. & n.d. & n.d. & n.d. & n.d. \\
Faixas gramadas & $10-20$ & $0-10$ & $0-10$ & $0-10$ & n.d. \\
Valetas gramadas & $20-40$ & $0-15$ & $0-15$ & $0-20$ & n.d. \\
Bacias de detenção secas & $50-70$ & $10-20$ & $10-20$ & $30-60$ & $50-90$ \\
Bacias de detenção alagadas & $60-95$ & $0-80$ & $0-80$ & $0-70$ & n.d. \\
Alagadiços & 40 & $9-60$ & $9-60$ & 60 & n.d. \\
Pavimento poroso & $80-95$ & 65 & 65 & 99 & n.d. \\
\hline
\end{tabular}

n.d.: informação não disponível

Fonte: Urban Drainage and Flood Control District (1992 apud PMSP, 1999).

Um aspecto relevante a ser destacado é a diferença entre os sistemas de distribuição de água potável e coleta de esgoto, e o sistema de drenagem urbana. Este último funciona apenas no período chuvoso (uns poucos meses durante o ano) e o resto do tempo fica ocioso; enquanto os outros dois sistemas funcionam os 365 dias do ano.

Esse comportamento característico do sistema de drenagem urbana o torna uma infraestrutura relativamente cara se comparada a seu uso. Então, com o intuito de melhorar a relação custo-benefício surge uma nova tendência no desenvolvimento de sistemas de drenagem urbana que é a incorporação de funções múltiplas a essa infra-estrutura.

Especificamente com relação às bacias de detenção, Walesh (1989) cita que a incorporação de funções múltiplas fica evidente ao se analisar a evolução mundial de utilização das obras de detenção em centros urbanos. Conforme mostra a Figura 1, distinguem-se pelo menos quatro fases: numa primeira fase, as obras de detenção visavam apenas ao controle quantitativo do escoamento; numa fase posterior, além da função específica do controlo do escoamento superficial, foram concebidas e integradas à paisagem urbana de modo a servir também como um espaço de recreação e lazer; na terceira fase, soma-se mais uma função que é a de contribuir para a melhoria da qualidade do escoamento superficial; entretanto, na quarta fase, os esforços são concentrados em estudar a viabilidade de se usar esse volume de água armazenado como eventual fonte de abastecimento.

Diante do exposto, o presente estudo apresenta os resultados obtidos do monitoramento de duas bacias de detenção, uma alagada (que se comporta também como bacia de retenção) e 
uma seca, situadas na cidade de Brasília - DF, tendo como objetivo, avaliar a eficiência delas no amortecimento do pico das cheias e, ainda, observar os seus comportamentos no que diz respeito à remoção da concentração de poluentes trazidos pelo escoamento superficial e a possível contaminação das águas pluviais por esgoto doméstico.

A motivação implícita neste estudo é a verificação da viabilidade, ou não, no contexto da cidade de Brasília, da possibilidade de implementar medidas compensatórias para o controle do escoamento pluvial urbano e que também atendam a outras finalidades.

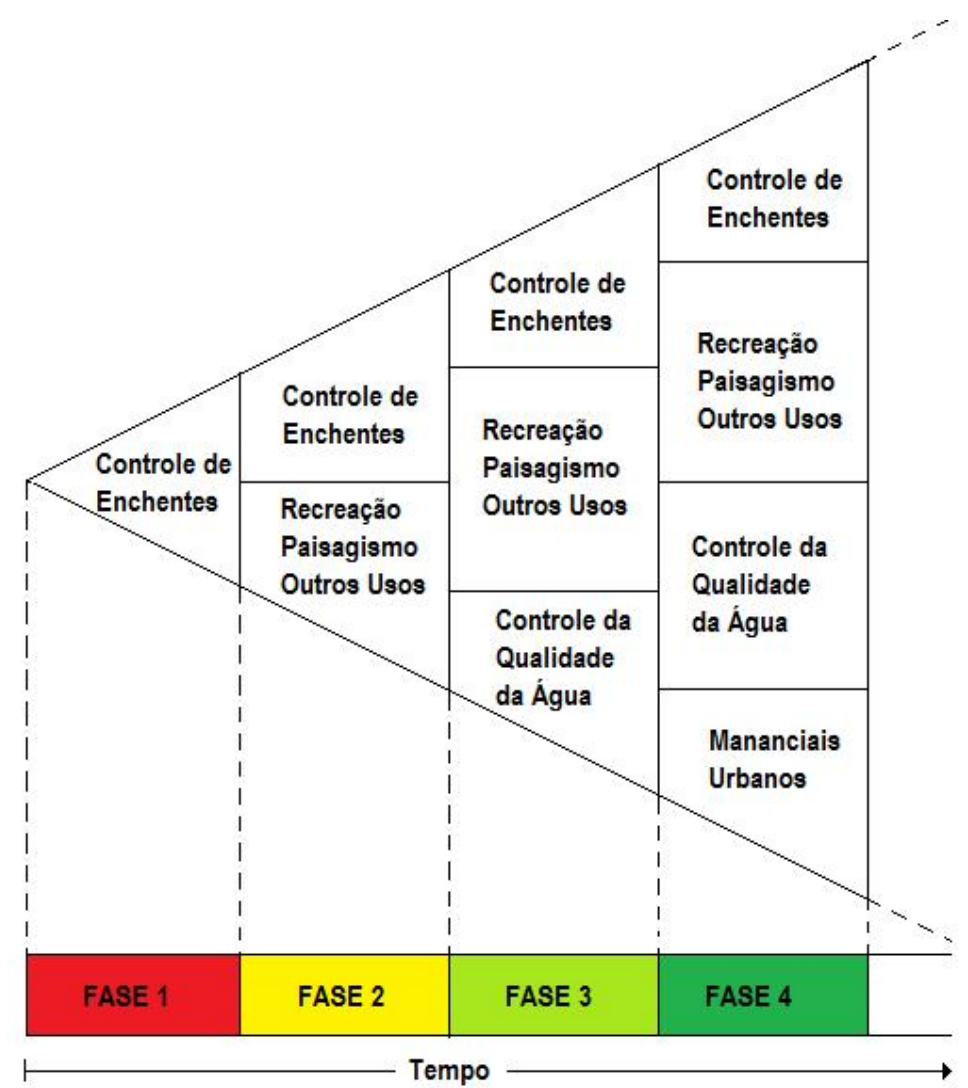

Figura 1. Evolução da utilização de estruturas de detenção em áreas urbanas

\section{MATERIAL E MÉTODOS}

As bacias de detenção monitoradas se encontram localizadas no Plano Piloto da cidade de Brasília - DF, conforme ilustrado na Figura 2, e recebem os escoamentos provenientes de zonas residenciais, comerciais e de vias expressas.

Quanto ao clima, no Distrito Federal predomina o quente e semi-úmido. Segundo a classificação de Köppen, o clima dominante no Distrito Federal é o tropical (Aw) e o tropical de altitude (Cwa) e (Cwb). Existem duas estações bem definidas, uma chuvosa e quente que ocorre entre os meses de outubro e abril, e outra fria e seca que ocorre entre maio e setembro. Os meses mais chuvosos são os de novembro a janeiro. Com relação aos índices de precipitação, a média pluviométrica anual fica em torno de 1500 a $1700 \mathrm{~mm}$. Já a média térmica anual varia entre 22 a $24^{\circ} \mathrm{C}$, a média máxima ultrapassa $25^{\circ} \mathrm{C}$ e a média mínima alcança $18^{\circ} \mathrm{C}$ (Gomes, 2004).

Essas bacias têm as características descritas a seguir: 


\subsection{Bacia de Detenção “Alagada”}

A bacia de detenção monitorada encontra-se localizada no Parque da Cidade de BrasíliaBrasil e é uma bacia permanentemente alagada, que além do controle de inundações é elemento urbanístico do referido parque, bastante freqüentado pela comunidade da cidade. Essa bacia recebe o escoamento de uma área de drenagem de $6,12 \mathrm{~km}^{2}$, sendo $0,11 \mathrm{~km}^{2}$ de área comercial, 2,28 $\mathrm{km}^{2}$ de área residencial, $3,28 \mathrm{~km}^{2}$ de área sem ocupação (gramada, em parque ou cerrado) e $0,45 \mathrm{~km}^{2}$ ocupado pelo sistema viário, incluindo calçadas e passeios, e apresenta as seguintes características: área de $0,167 \mathrm{~km}^{2}$, profundidade média de $0,68 \mathrm{~m}$, comprimento no sentido longitudinal predominante do escoamento de $809 \mathrm{~m}$.

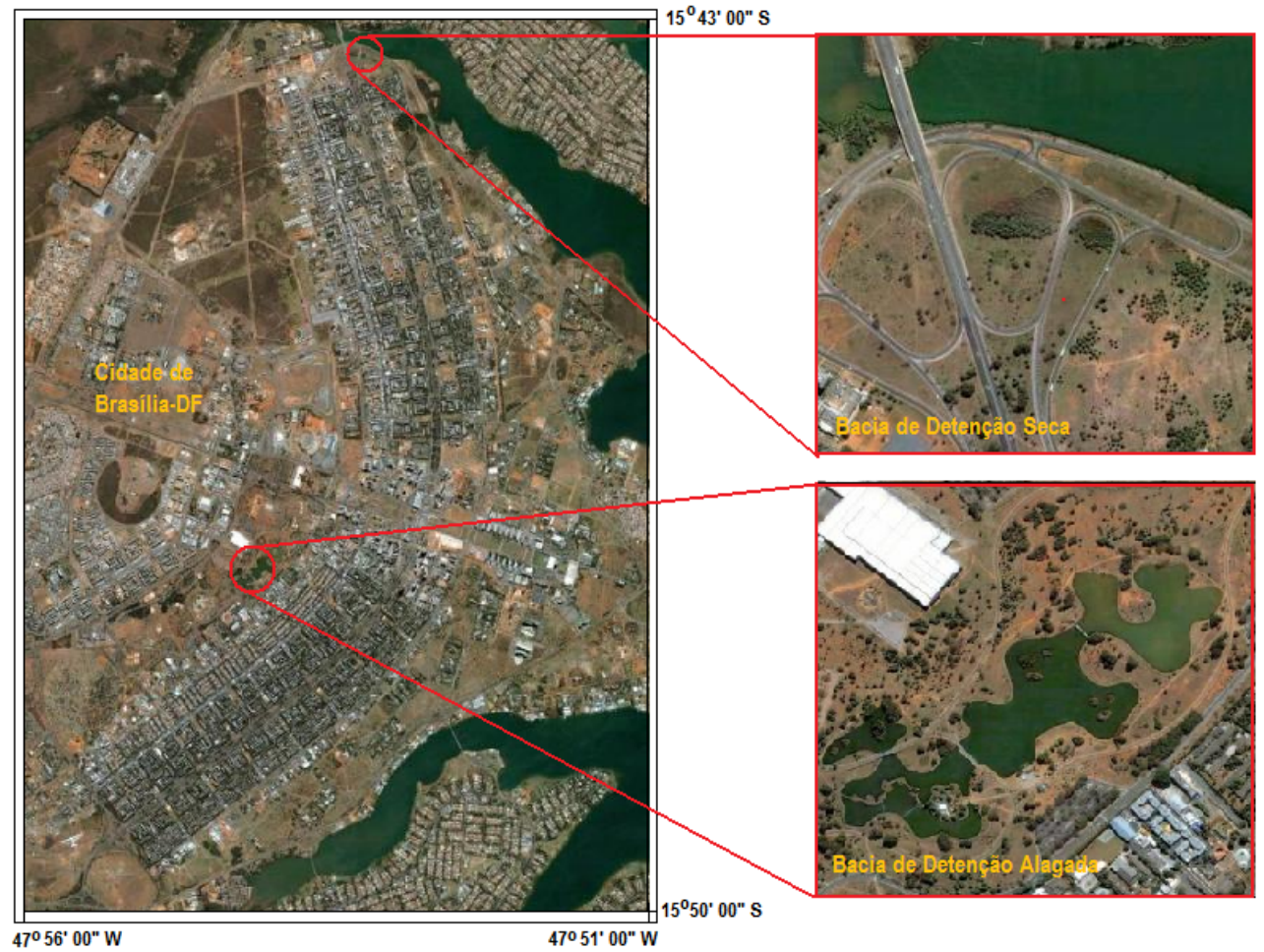

Figura 2. Localização das bacias de retenção monitoradas (imagem Spot 5 de 17/07/2005).

\subsection{Bacia de Detenção “Seca”}

Esta bacia de detenção está localizada no final do bairro Asa Norte, é uma bacia de detenção seca, menor que a bacia de detenção alagada e recebe o escoamento proveniente de uma área de contribuição de $4,75 \mathrm{~km}^{2}$, sendo $0,64 \mathrm{~km}^{2}$ utilizado pelo comércio local, $1,05 \mathrm{~km}^{2}$ de área residencial composta por edifícios, $2,68 \mathrm{~km}^{2}$ de área sem ocupação destinada à área gramada, parque e cerrado e $0,38 \mathrm{~km}^{2}$ ocupada pelo sistema viário incluindo calçadas e passeios, e possui as seguintes características: área de $0,024 \mathrm{~km}^{2}$, profundidade média de 0,52m, comprimento da direção predominante do escoamento de $63 \mathrm{~m}$.

Para o presente estudo foram coletados dados de vazão (hidrograma de escoamento superficial) e qualidade da água nas canalizações de entrada da bacia de detenção, aqui denominadas de seção de montante, e nas canalizações de saída da bacia de detenção, aqui denominadas de seção de jusante.

\subsection{Monitoramento Quantitativo}

A estratégia de monitoramento das bacias de detenção foi elaborada com base nas propostas apresentadas por EPA (1986), e Guo e Urbonas (2002). Basicamente, consistiu da determinação da vazão de montante e a de jusante das bacias de detenção feita utilizando-se 
um vertedor triangular e régua linimétrica. Em cada um dos eventos monitorados foram realizadas medições de vazão em intervalos de cinco minutos ao longo de períodos que variaram de quatro a cinco horas para a maioria dos eventos, mas para um dos eventos monitorados o período total de medição foi de sete horas e meia.

O comportamento da bacia de detenção seca foi monitorado para três eventos chuvosos, enquanto o monitoramento do comportamento da bacia de detenção alagada se deu para outros dois eventos chuvosos. Nesta última bacia foi, também, medido o hidrograma de entrada durante um dia no qual não houve ocorrência de precipitação, com o intuito de verificar a existência de ligações clandestinas de esgoto na rede de drenagem.

O período de monitoramento de ambas as bacias foi de 14/12/2004 até 21/2/2005. Os motivos pelos quais a quantidade de eventos monitorados foi muita reduzida são: após monitorar o segundo evento na bacia alagada, os equipamentos de medição de vazão (vertedor e régua linimétrica) foram depredados; b) a bacia seca possuía apenas uma entrada, mas após monitorar o terceiro evento, sua estrutura foi modificada, incorporando-se mais entradas o que impossibilitou a continuidade do monitoramento em função da reduzida quantidade de equipamento disponível para esta finalidade.

\subsection{Monitoramento Qualitativo}

A concepção do monitoramento da qualidade do escoamento baseou-se nas sugestões de EPA (1986), Gray e Becker (2002), Lee e Bang (2000) e Lee et al. (2002), que recomendam tomar cuidado para que os parâmetros escolhidos para análise de amostras do escoamento envolvam a análise de, no mínimo, matéria orgânica, nutrientes, microbiologia e metais pesados. A escolha dos parâmetros para o presente trabalho foi baseada nesse princípio, além de levar em conta também os parâmetros mais usuais.

As características físicas do efluente foram analisadas por meio da medida da temperatura e sólidos em suspensão. As características químicas foram analisadas por meio do $\mathrm{pH}$, condutividade (quantidade de sais) e metais pesados. Os nutrientes foram avaliados por meio do orto-fosfato e nitrato. Os parâmetros utilizados para análise de matéria orgânica contida na água foram DBO, DQO e óleos e graxas. Já as características microbiológicas foram analisadas por meio da medida de coliformes totais e termotolerantes.

A metodologia utilizada para análise de cada parâmetro, de acordo com o Standard Methods (APHA; AWWA; WPCF, 2005) é apresentada na Tabela 2.

Tabela 2. Métodos utilizados para análise dos parâmetros de qualidade da água.

\begin{tabular}{ll}
\hline Parâmetro & Método Utilizado \\
\hline Temperatura & Termômetro \\
pH & Phmetro \\
Condutividade elétrica & Condutivímetro \\
DBO & Respirométrico \\
DQO & Colorimétrico de refluxo fechado \\
Orto-fosfato & Colorimétrico do ácido ascórbico \\
Nitrato & Colorimétrico \\
Coliformes & Colilert \\
Sólidos em suspensão & Gravimétrico \\
Óleos e graxas & Gravimétrico
\end{tabular}

Foram coletadas amostras do escoamento pluvial a montante e a jusante da bacia de detenção, ao longo dos eventos chuvosos para caracterizar e avaliar a contribuição dessas bacias na melhora da qualidade da água da drenagem pluvial. 
Em função de ter sido observado no escoamento de entrada da bacia de detenção alagada que, em determinados horários, havia uma concentração maior de substâncias características de esgotos domésticos, suspeitou-se da existência de conexões clandestinas de esgoto na rede de drenagem pluvial. Sendo assim, foi feita uma campanha para determinação da vazão e das respectivas concentrações de poluentes na água da rede de drenagem em um dia sem chuva.

\section{RESULTADOS E DISCUSSÃO}

As Figuras de 3 a 5 correspondem aos hidrogramas de escoamento superficial registrados na bacia de detenção seca; entretanto as Figuras 6 e 7 mostram os hidrogramas medidos na bacia de detenção alagada. Esses resultados mostram claramente a eficiência hidráulica das bacias de detenção no que diz respeito à redução das vazões de pico das ondas de cheia, principalmente da bacia de detenção alagada que pelo seu maior tamanho apresenta, conseqüentemente, uma maior capacidade de amortecimento das vazões.

A Tabela 3 apresenta os valores das vazões de pico medidas na seção de montante e na seção de jusante para os eventos com chuva das bacias de detenção monitoradas; o tempo ao pico para cada caso; a porcentagem de redução observada na vazão de pico; a precipitação observada; assim como a precipitação antecedente (precipitação total acumulada ocorrida nos cinco dias anteriores ao evento monitorado).

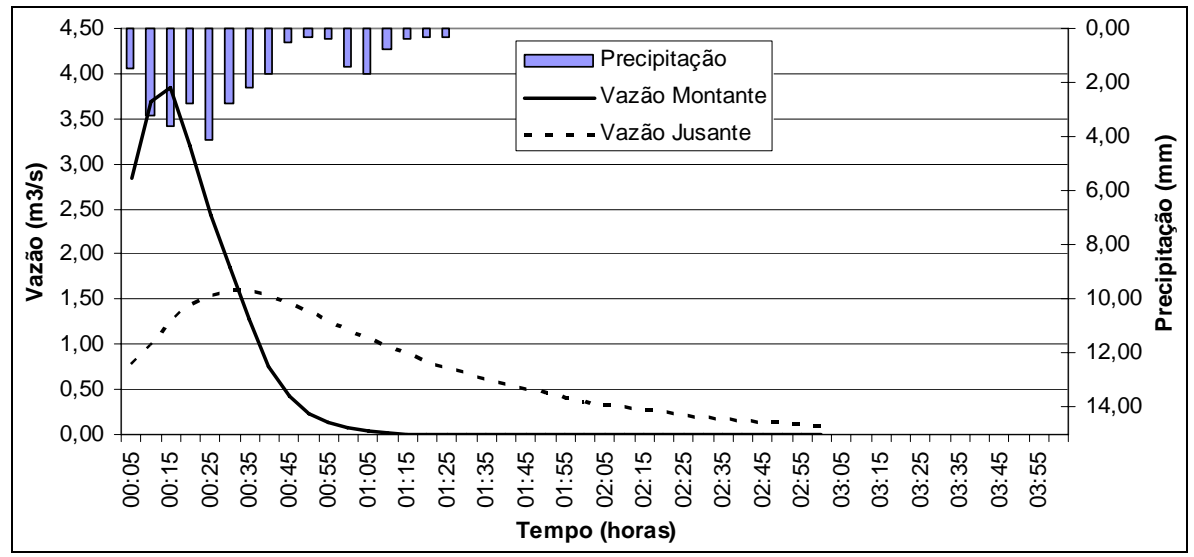

Figura 3. Hidrogramas nas seções de montante e jusante na bacia de detenção seca - Evento 1.

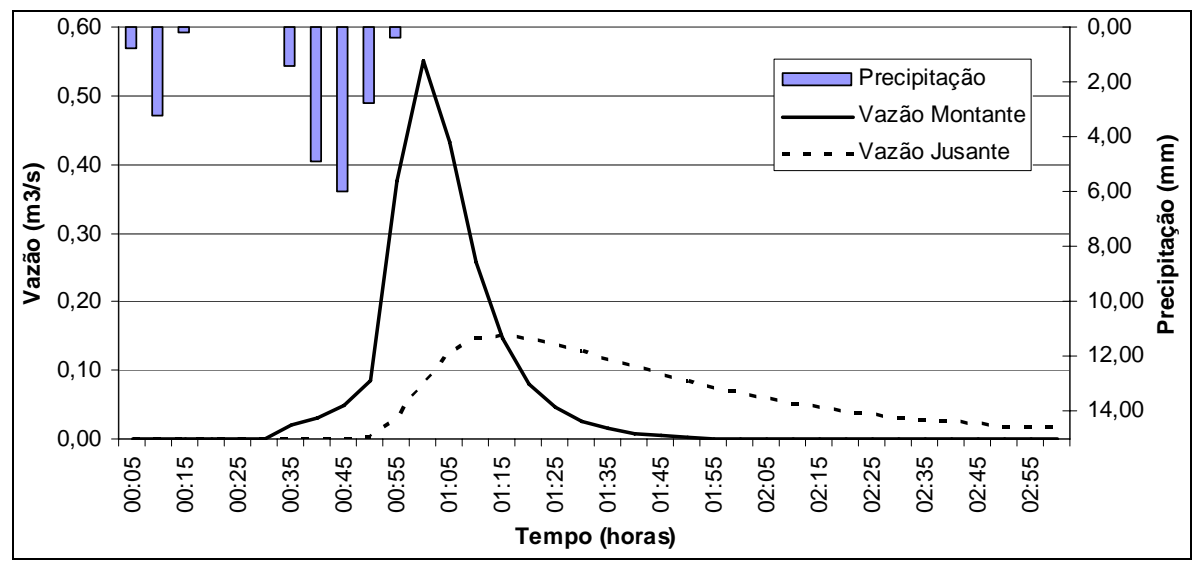

Figura 4. Hidrogramas nas seções de montante e jusante na bacia de detenção seca - Evento 2. 


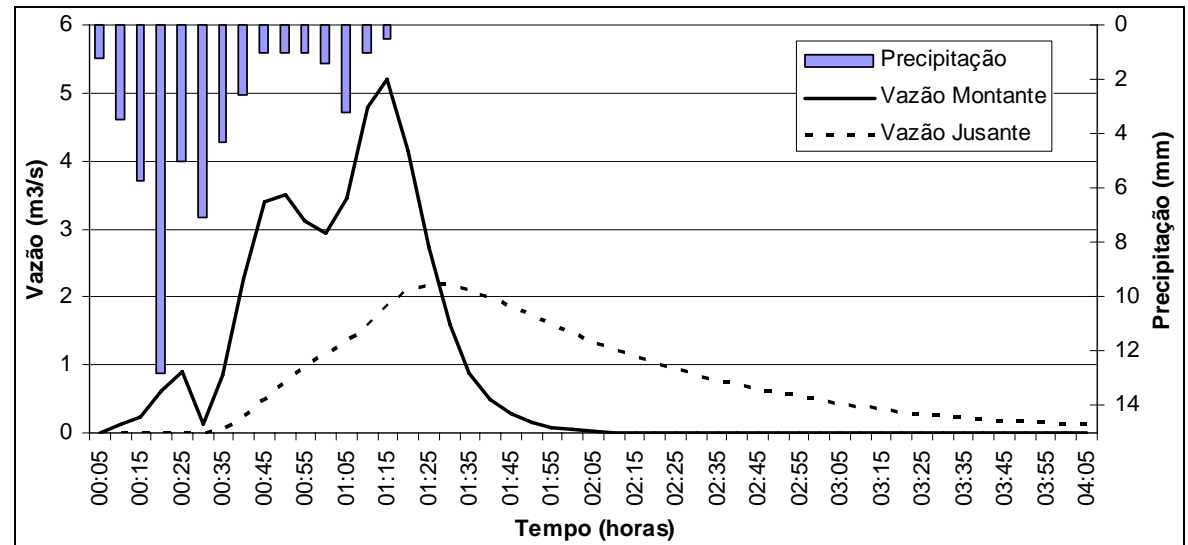

Figura 5. Hidrogramas nas seções de montante e jusante na bacia de detenção seca - Evento 3.

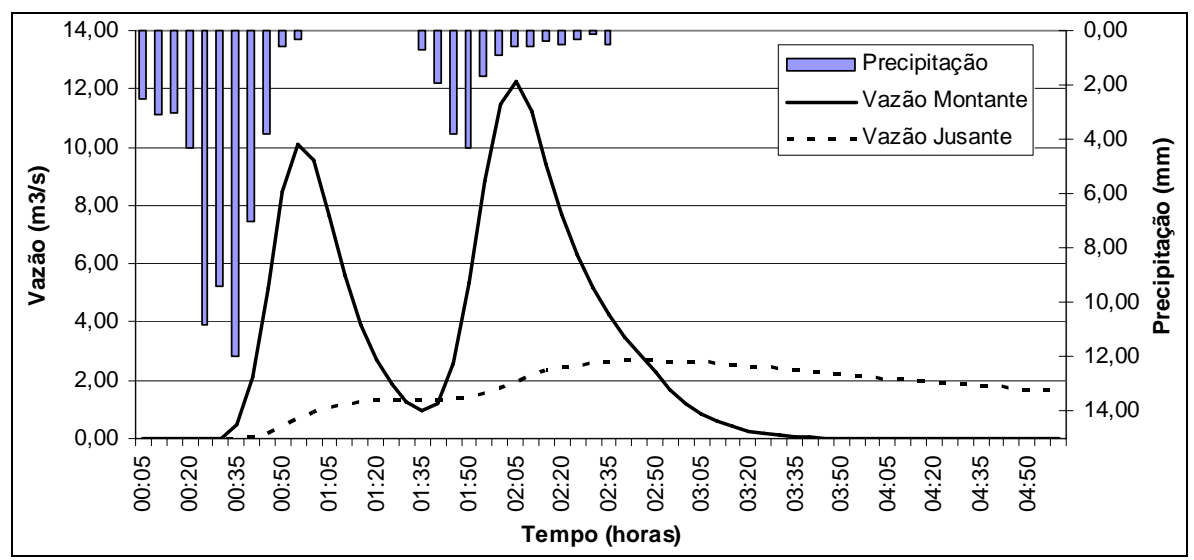

Figura 6. Hidrogramas nas seções de montante e jusante na bacia de detenção alagada - Evento 1.

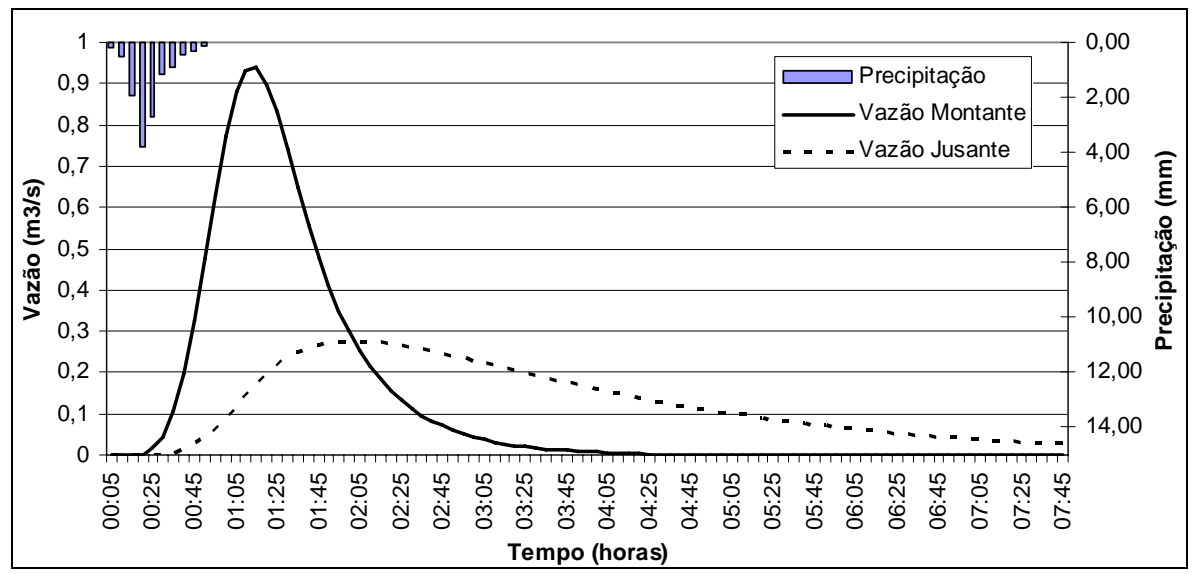

Figura 7. Hidrogramas nas seções de montante e jusante na bacia de detenção alagada - Evento 2.

Assim como observado nas Figuras 3 a 7, os dados da Tabela 3 vêm comprovar a eficiência hidráulica de bacias de detenção tanto seca quanto inundada como mecanismo para o controle de cheias em áreas urbanas, uma vez que a redução média observada na vazão de pico foi de $62,6 \%$ e $74 \%$, para a bacia de detenção seca e alagada, respectivamente. Além da alta taxa de redução das vazões de pico observadas para a bacia de detenção alagada, pode-se ainda observar o aumento significativo no tempo ao pico para esta bacia. O mesmo não 
ocorreu para a bacia de detenção seca porque ela possui dimensões reduzidas em relação à bacia de detenção inundada.

Tabela 3. Valores das vazões de pico para os eventos monitorados a montante e a jusante e porcentagem de redução da vazão de pico.

\begin{tabular}{|c|c|c|c|c|c|c|c|c|}
\hline $\begin{array}{l}\text { Bacia de } \\
\text { detenção }\end{array}$ & Evento & $\begin{array}{c}\text { Vazão de } \\
\text { pico de } \\
\text { montante } \\
\left(\mathbf{m}^{3} / \mathbf{s}\right)\end{array}$ & $\begin{array}{l}\text { Tempo ao } \\
\text { pico de } \\
\text { montante } \\
\text { (h) }\end{array}$ & $\begin{array}{c}\text { Vazão de } \\
\text { pico de } \\
\text { jusante } \\
\left(\mathbf{m}^{3} / \mathbf{s}\right)\end{array}$ & $\begin{array}{l}\text { Tempo ao } \\
\text { pico de } \\
\text { jusante } \\
\text { (h) }\end{array}$ & $\begin{array}{c}\text { Redução } \\
\text { da vazão } \\
\text { de pico } \\
(\%)\end{array}$ & $\begin{array}{c}\text { Precipitação } \\
\text { (mm) }\end{array}$ & $\begin{array}{c}\text { Precipitação } \\
\text { antecedente } \\
(\mathbf{m m})\end{array}$ \\
\hline \multirow{3}{*}{ Seca } & 1 & 3,84 & $01: 55$ & 1,6 & 01:30 & 58 & 28,0 & 5,3 \\
\hline & 2 & 0,55 & 01:00 & 0,15 & 01:10 & 72 & 19,7 & 0,0 \\
\hline & 3 & 5,2 & $01: 15$ & 2,19 & $01: 25$ & 58 & 51,3 & 0,0 \\
\hline \multirow{3}{*}{ Alagada } & \multirow[t]{2}{*}{1} & 10,08 & $00: 55$ & \multirow{2}{*}{2,69} & \multirow{2}{*}{ 02:45 } & 73 & \multirow{2}{*}{73,1} & \multirow{2}{*}{12,8} \\
\hline & & 12,26 & 02:05 & & & 78 & & \\
\hline & 2 & 0,94 & 01:15 & 0,276 & 01:55 & 71 & 12,04 & 7,6 \\
\hline
\end{tabular}

No que se refere ao aspecto qualitativo do escoamento pluvial, as concentrações médias dos diversos parâmetros monitorados são apresentadas nas Tabelas 4 e 5, enquanto os valores da Tabela 6 referem-se à taxa média de redução da concentração de poluentes registrada na bacia de detenção.

A concentração média de cada parâmetro para cada evento chuvoso monitorado foi estimada da seguinte forma:

$$
C M E=\frac{\sum_{i=1}^{n} C_{i} \cdot Q_{i}}{\sum_{i=1}^{n} Q_{i}}
$$

Em que: $C M E$ é a concentração média do evento; $C_{i}$ é a concentração de cada amostra; $Q_{i}$ é a vazão do escoamento superficial no momento da coleta da amostra; e $n$ é a quantidade de amostras coletadas

Tabela 4. Concentração média dos parâmetros da qualidade do escoamento pluvial para a bacia de detenção seca.

\begin{tabular}{|c|c|c|c|c|c|c|c|c|c|c|c|}
\hline Evento & $\begin{array}{c}\text { Temp } \\
\left({ }^{\circ} \mathrm{C}\right)\end{array}$ & pH & $\begin{array}{l}\text { Condut. } \\
(\mu S / \mathbf{c m})\end{array}$ & $\begin{array}{c}\text { DQO } \\
(\mathrm{mg} / \mathrm{l})\end{array}$ & \begin{tabular}{|c|} 
DBO \\
(mg/l)
\end{tabular} & $\begin{array}{c}\text { Sol. } \\
\text { Suspen. } \\
\text { (mg/l) }\end{array}$ & $\begin{array}{c}\text { Nitrat } \\
\text { o } \\
(\mathrm{mg} / \mathrm{l})\end{array}$ & $\begin{array}{c}\text { Colif. } \\
\text { Totais } \\
(\mathrm{NMP} / \mathbf{1 0 0 m l})\end{array}$ & $\begin{array}{c}\text { Colif. } \\
\text { Termotoler } \\
\text { (NMP/100ml) }\end{array}$ & $\begin{array}{c}\text { Orto- } \\
\text { Fosfato } \\
\text { (mg/l) }\end{array}$ & $\begin{array}{c}\text { Óleos e graxas } \\
\text { (mg/l) }\end{array}$ \\
\hline \multicolumn{12}{|c|}{ Dados de Montante (seção de entrada) } \\
\hline 1 & 22,1 & 7,0 & 30,71 & 12,20 & 3,30 & 17,37 & 0,43 & 316800 & 21180 & 0,070 & 4,058 \\
\hline 2 & 19,2 & 6,5 & 29,19 & 15,19 & 1,29 & 12,15 & 0,35 & 327000 & 17425 & 0,071 & 11,270 \\
\hline 3 & 0,0 & 6,8 & 23,60 & 13,10 & 2,95 & 20,81 & 0,69 & 361023 & 20299 & 0,000 & 8,252 \\
\hline \multicolumn{12}{|c|}{ Dados de Jusante (seção de saída) } \\
\hline 1 & n.d. & 4,4 & n.d. & 11,66 & 3,20 & 8,97 & 0,39 & 299220 & n.d. & 0,065 & 3,380 \\
\hline 2 & n.d. & 7,3 & n.d. & 14,44 & 2,09 & 7,16 & 0,32 & 300840 & n.d. & 0,062 & 9,580 \\
\hline 3 & n.d. & 6,9 & n.d. & 12,65 & 2,77 & 10,63 & 0,60 & 326502 & n.d. & 0,000 & 7,664 \\
\hline
\end{tabular}

n.d.: informação não disponível. 
Tabela 5. Concentração média dos parâmetros da qualidade do escoamento pluvial para a bacia de detenção alagada.

\begin{tabular}{|c|c|c|c|c|c|c|c|c|c|c|c|}
\hline Evento & $\begin{array}{c}\text { Temp } \\
\left({ }^{\circ} \mathrm{C}\right)\end{array}$ & $\mathbf{p H}$ & $\begin{array}{l}\text { Condut. } \\
(\mu \mathrm{S} / \mathrm{cm})\end{array}$ & $\begin{array}{c}\text { DQO } \\
\text { (mg/l) }\end{array}$ & $\begin{array}{c}\text { DBO } \\
(\mathrm{mg} / \mathrm{l})\end{array}$ & $\begin{array}{c}\text { Sol. } \\
\text { Suspen. } \\
\text { (mg/l) }\end{array}$ & $\begin{array}{c}\text { Nitrato } \\
\text { (mg/l) }\end{array}$ & $\begin{array}{c}\text { Colif. } \\
\text { Totais } \\
(\mathrm{NMP} / 100 \mathrm{ml}) \\
\end{array}$ & \begin{tabular}{|c|} 
Colif. \\
Termotoler \\
(NMP/100ml)
\end{tabular} & $\begin{array}{c}\text { Orto- } \\
\text { Fosfato } \\
\text { (mg/l) }\end{array}$ & $\begin{array}{l}\text { Óleos e } \\
\text { graxas } \\
\text { (mg/l) } \\
\end{array}$ \\
\hline \multicolumn{12}{|c|}{ Dados de Montante (seção de entrada) } \\
\hline 1 & n.d. & 6,79 & & 74,50 & 9,25 & 95,00 & 1,10 & 536000 & 52033 & 0,168 & 12,650 \\
\hline 2 & n.d. & 6,59 & 53,16 & 36,05 & 9,17 & 95,05 & 1,15 & 1655608 & 89307 & 0,141 & 14,135 \\
\hline \multicolumn{12}{|c|}{ Dados de Jusante (seção de saída) } \\
\hline 1 & n.d. & 7,43 & n.d. & 67,32 & 8,44 & 43,40 & 0,81 & 477150 & n.d. & n.d. & 12,860 \\
\hline 2 & n.d. & 7,16 & n.d. & 33,24 & 8,65 & 37,83 & 1,03 & 1403493 & n.d. & n.d. & 11,515 \\
\hline
\end{tabular}

n.d.: informação não disponível.

Vale ressaltar a dificuldade de se conhecer com exatidão a qualidade das águas do escoamento pluvial urbano em função da existência de conexões clandestinas de esgoto na rede de drenagem, fato este comprovado com o monitoramento da bacia de detenção alagada em um dia (17/01/2005) sem ocorrência de chuva. O hidrograma observado nesse dia é mostrado na figura 8, enquanto na tabela 7, apresentam-se os dados de qualidade desse esgoto.

Tabela 6. Porcentagem de redução da concentração de poluentes para as bacias de detenção monitoradas.

\begin{tabular}{|l|c|c|}
\hline \multicolumn{1}{|c|}{ Parâmetro } & $\begin{array}{c}\text { \% de redução da bacia de } \\
\text { detenção seca }\end{array}$ & $\begin{array}{c}\text { \% de redução na bacia de } \\
\text { detenção alagada }\end{array}$ \\
\hline DQO & $4-7$ & $7-10$ \\
\hline DBO & $1-3$ & $5-9$ \\
\hline Sólidos Suspensos & $38-54$ & $41-74$ \\
\hline Nitrato & $7-11$ & $7-14$ \\
\hline Coliformes totais & $5-9$ & $10-24$ \\
\hline Óleos e graxas & $14-21$ & $14-21$ \\
\hline
\end{tabular}

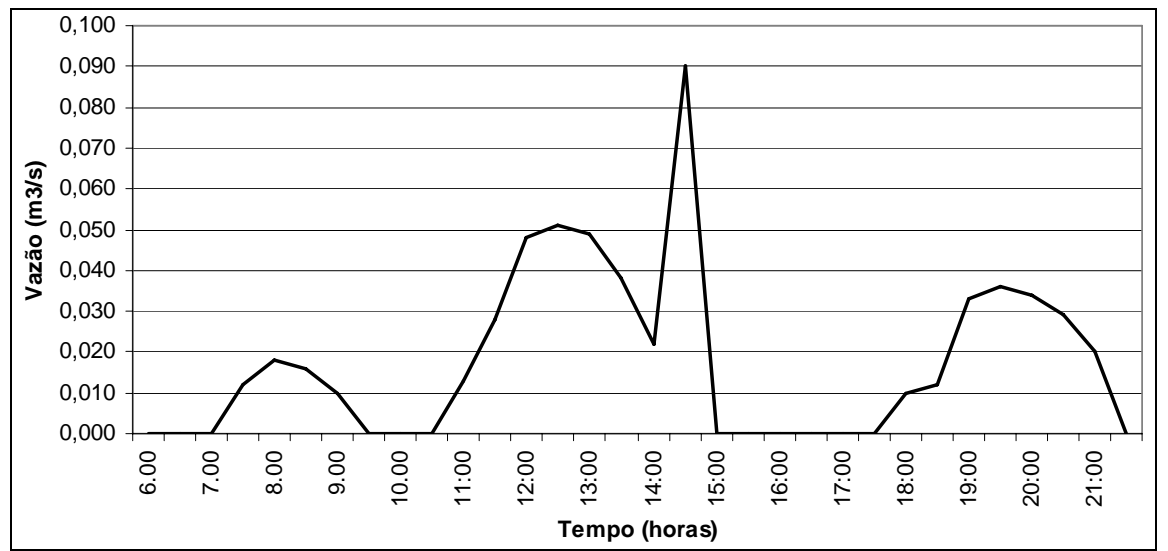

Figura 8. Hidrograma da seção de montante na bacia de detenção. Para um dia sem ocorrência de chuva. 
Tabela 7. Concentração média dos parâmetros da qualidade do escoamento pluvial para a bacia de detenção alagada.

\begin{tabular}{c|c|c|c|c|c|c|c|c}
\hline $\begin{array}{c}\text { Temp } \\
\left({ }^{\mathbf{O}} \mathbf{C}\right)\end{array}$ & $\mathbf{p H}$ & $\begin{array}{c}\text { Condut } \\
(\mathbf{\mu S / c m})\end{array}$ & $\begin{array}{c}\text { DQO } \\
(\mathbf{m g} / \mathbf{l})\end{array}$ & $\begin{array}{c}\text { DBO } \\
(\mathbf{m g} / \mathbf{l})\end{array}$ & $\begin{array}{c}\text { Sol. } \\
\text { Suspen. } \\
(\mathbf{m g} / \mathbf{l})\end{array}$ & $\begin{array}{c}\text { Nitrat } \\
\mathbf{o} \\
(\mathbf{m g} / \mathbf{l})\end{array}$ & $\begin{array}{c}\text { Colif. } \\
\text { Totais } \\
(\mathbf{N M P} / \mathbf{1 0 0 m l})\end{array}$ & $\begin{array}{c}\text { Colif. } \\
\text { Termotoler } \\
(\mathbf{N M P} / \mathbf{1 0 0 m})\end{array}$ \\
\hline 23 & 6,9 & 211,14 & 55,9 & 22,1 & 9,4 & 0,3 & 251.000 & 236.000 \\
\hline
\end{tabular}

Da observação dos dados apresentados na tabela 7, percebe-se que existe a possibilidade de que esse efluente seja proveniente tanto de ligações clandestinas de esgotos domésticos residenciais e comerciais quanto de ligações clandestinas de drenagem de jardins.

Há também a possibilidade de que esse escoamento se deva à própria infiltração da água. Essa conclusão é obtida devido aos baixos valores de DBO e DQO encontrados se comparados aos valores de esgotos brutos. A hipótese levantada quanto à presença de esgoto é devida, principalmente, à quantidade de coliformes termotolerantes e totais encontradas, embora não se saiba ao certo o valor de coliformes totais. Porém, percebe-se que o valor dos coliformes termotolerantes ficou um pouco abaixo do valor típico de esgoto bruto.

Contudo, a hipótese mais provável é que existam ligações clandestinas de esgoto bruto de residências e de comércios, porém esse esgoto pode estar sendo diluído pela presença de ligações clandestinas de drenagem de jardins e pela presença de águas subterrâneas.

Dado que os resultados evidenciaram a efetividade das bacias de detenção na melhoria da qualidade do escoamento pluvial urbano, o passo seguinte foi a determinação do coeficiente de remoção de poluente, pois este poderia ser usado como parâmetro de dimensionamento destas estruturas de detenção do escoamento.

Assim, considerando que a bacia alagada tem funcionamento como reator de fluxo disperso utilizaram-se os resultados das análises de qualidade da água para os eventos analisados para ajustar o modelo proposto por Metcalf e Eddy (1991), isto é, estimar o coeficiente de remoção de poluente:

$$
S=S_{0} \cdot \frac{4 \cdot a \cdot e^{1 / 2 \cdot d}}{(1+a)^{2} \cdot e^{a / 2 \cdot d}-(1-a)^{2} \cdot e^{-a / 2 \cdot d}}
$$

$d=\frac{D}{U \cdot L}=\frac{D \cdot t}{L^{2}}$

$a=\sqrt{1+4 \cdot K \cdot t \cdot d}$

Em que: $\mathrm{S}$ é a concentração do poluente efluente (massa $\cdot$ volume ${ }^{-1}$ ); $\mathrm{S}_{0}$ é a concentração do poluente afluente (massa $\cdot$ volume $^{-1}$ ); K é o coeficiente de remoção do poluente (tempo ${ }^{-1}$ ); $\mathrm{t}$ é o tempo de detenção (tempo); d é o número de dispersão (adimensional); D é o coeficiente de dispersão longitudinal (distância ${ }^{2} \cdot$ tempo $^{-1}$ ); U é a velocidade média na lagoa (distância • tempo $^{-1}$ ); e L é o comprimento do percurso longitudinal na lagoa (distância).

Chegou-se à conclusão de que é possível agrupar os poluentes em dois grandes grupos, considerando o coeficiente de remoção do poluente (K): a) Poluentes tipicamente em solução; e b) Poluente tipicamente em suspensão.

Aqueles com característica de material predominantemente em solução ou em partículas muito pequenas podem-se considerar representados pelos parâmetros DQO, DBO, nitrato, 
orto-fosfato e organismos coliformes. Para esse grupo de poluentes, os valores de $\mathrm{K}$ obtidos estão ao redor de $0,5 \mathrm{dia}^{-1}$.

Aqueles com características de material em suspensão, encontram-se os representados pelos parâmetros sólidos em suspensão e óleos e graxas. Nesses casos, os valores de K são superiores ao encontrado para os poluentes dissolvidos. Para o caso dos representados por sólidos em suspensão, os valores de $\mathrm{K}$ obtidos estão na ordem de 3,0 dia ${ }^{-1}$; no caso dos representados por óleos e graxas, os valores de $\mathrm{K}$ foram da ordem de $1,0 \mathrm{dia}^{-1}$.

A primeira grande conclusão é que a bacia remove, com maior eficiência, o grupo de poluentes com característica de material em suspensão. Essa característica está associada ao processo de remoção, que nesses sistemas funciona predominantemente como processo físico. Sobre a diferença entre aqueles caracterizados como sólidos suspensos e os óleos e graxas, a explicação pode ser dada pela característica do funcionamento hidráulico das bacias, onde o material flotante tem menor restrição para saída do que o material que sedimenta. Essas considerações podem levar a estudos sobre dispositivos de saída, procurando aumentar a eficiência do material flotante.

Comparando-se o desempenho das duas bacias, no tocante a remoção de poluentes, podese perceber que a bacia alagada tem desempenho um pouco superior à bacia seca. Isso pode ser explicado pelo fato de que a bacia alagada funciona semelhantemente a uma lagoa de estabilização, com desempenho ampliado pela razão de funcionar como um reator bioquímico.

Também, segundo Novotny (1991), pode-se considerar que a bacia seca funciona como reator de mistura completa, e assim tentou-se usar os resultados das análises de qualidade da água para os eventos analisados para ajustar o modelo proposto por Metcalf e Eddy (1991):

$$
S=\frac{S_{0}}{1+K \cdot t}
$$

Em que: S é a concentração do poluente efluente (massa $\cdot$ volume $^{-1}$ ); $\mathrm{S}_{0}$ é a concentração do poluente afluente (massa $\cdot$ volume $^{-1}$ ); $\mathrm{K}$ é o coeficiente de remoção do poluente (tempo ${ }^{-1}$ ); e t é o tempo de detenção (tempo).

Analogamente ao caso da bacia alagada, aqueles poluentes com característica de material predominantemente em solução ou em partículas muito pequenas podem-se considerar representados pelos parâmetros DQO, DBO, nitrato, orto-fosfato e organismos coliformes. Para esse grupo obteve-se um valor médio de $\mathrm{K}$ de $0,34 \mathrm{dia}^{-1}$. Para o caso dos poluentes representados por sólidos em suspensão, o valor médio de $\mathrm{K}$ foi $5,5 \mathrm{dia}^{-1}$; entretanto no caso dos poluentes representados por óleos e graxas, os valores de K estão na ordem de 1,1 dia $^{-1}$.

Da análise dos resultados, pode-se afirmar que a hipótese de ser possível encontrar um valor de K que funcione como parâmetro de dimensionamento parece viável. Entretanto, para que o modelo seja confirmado é necessário monitorar outras estruturas de retenção para ter mais segurança na estatística dos resultados.

\section{CONCLUSÕES}

Diante do exposto, pode-se concluir que a utilização de bacias de detenção como medida de controle de cheias apresenta resultados satisfatórios no aspecto quantitativo, podendo ainda colaborar para a redução da concentração dos poluentes oriundos dos diversos usos do solo em meio urbano que estejam em contato com as águas despejadas na rede de águas pluviais. 
Como era esperado, no presente estudo foi comprovada a existência, para a região do Distrito Federal, de um problema que aflige a maioria das cidades que adotam um sistema separador absoluto para esgoto: a contaminação das águas pluviais pela ligação clandestina de esgoto doméstico.

No tocante ao aspecto qualitativo das águas pluviais, a bacia de detenção alagada mostrou maior eficiência na retenção de poluentes, mas mesmo assim os valores apresentados ainda encontram-se muito aquém dos valores citados na literatura especializada, com exceção da remoção de sólidos em suspensão que apresentou uma taxa de remoção de 74\%.

Destaca-se aqui que os valores encontrados para o coeficiente de remoção do poluente (K) devem ser tomados com reservas, pois trata-se de uma primeira estimativa realizada com base num número reduzido de eventos observados. Contudo, há indícios claros da contribuição dessas estruturas na melhoria da qualidade do escoamento pluvial urbano.

\section{AGRADECIMENTOS}

Os autores agradecem a $\mathrm{CNPq}$ - Conselho Nacional de desenvolvimento Científico e Tecnológico, que financia o Projeto "Manejo de Águas Pluviais no Distrito Federal” no contexto do qual foi desenvolvida a presente pesquisa.

\section{REFERÊNCIAS}

AMERICAN PUBLIC HEALTH ASSOCIATION - APHA; American Water Works Association - AWWA; Water Environment Federation - WPCF. Standard methods for the examination of water and wasterwater. 16. ed. Washington: AWWA, 2005.

BAPTISTA, M.; NASCIMENTO, N.; BARRAUD, S. Técnicas compensatórias em drenagem urbana. Porto Alegre: ABRH, 2005. 266 p.

BERTONI, J. C. (org). Inundaciones urbanas en Argentina. Córdoba: Universitas, 2004. $254 \mathrm{p}$.

CAMPANA, N. A.; TUCCI, C. E. M. Predicting floods from urban development scenarios: case study of the Diluvio basin, Porto Alegre, Brazil. Urban Water, Oxford, v. 3, n. 2, p.113-124, 2001.

CANHOLI, A. P. Drenagem urbana e controle de enchentes. São Paulo: Oficina de Textos, 2005. 302 p.

CHOCAT, B.; ASHLEY, R.; MARSALEK, J.; MATOS, M. R.; RAUCH, W.; SCHILLING, W.; et al. Urban drainage - out-of-sight, out-of-mind? In: INTERNATIONAL CONFERENCE ON SUSTAINABLE TECHNIQUES AND STRATEGIES IN URBAN WATER MANAGEMENT, 5., June 6-10 2004, Lyon. Proceedings... Lyon: NOVATECH, 2004. p. 1659-1690.

ENVIRONMENTAL PROTECTION AGENCY - EPA. Methodology for analysis of detention basins for control of urban runoff quality. Washington: EPA, 1986. EPA440/5-87-001.

GOMES, V. M. Caracterização qualitativa e quantitativa da água de drenagem pluvial. 78f. 2004. Dissertação (Mestrado em Tecnologia Ambiental e Recursos Hídricos) Universidade de Brasília, Brasília, 2004. 
GRAY, S. R.; BECKER, N. S. C. Contaminant flows in urban residential water systems. Urban Water, v. 4, p.331-346, 2002.

GUO, JAMES C. Y.; URBONAS, B. Runoff capture and delivery curves for storm water quality control designs. ASCE Journal of Water Resources Planning and Management, v. 128, n. 3, p. 208-215. 2002.

JONES, J.; GUO, J. C. Y.; URBONAS, B. Safety on detention and retention pond designs. Journal of Storm Water, 2006.

LEE, J. H.; BANG, K. W. Characterization of urban stormwater runoff. Water Research, v. 34, n. 6, p. 1773-1780, 2000.

LEE, J. H.; BANG, K. W.; KETCHUM, L. H.; CHOE, J. S.; YU, M. J. First flush analysis of urban storm runoff. The Science of the Total Environment, v. 293, p. 163-175, 2002.

METCALF, J.; EDDY, H. Wastewater engineering: treatment, disposal and reuse. 3. ed. Singapure: McGraw-Hill, 1991. 334 p.

MAYS, L. W.; PE, P. H. Stormwater collection systems design handbook. [S.l.]: McGrawHill, 2001. 757 p.

NOVOTNY, V. Urban diffuse pollution: sources and abatement. Water Environment \& Technology, v. 3, n. 12, p.60-65, 1991.

PREFEITURA MUNICIPAL DE SÃO PAULO - PMSP. Diretrizes básicas para projetos de drenagem urbana no município de São Paulo. São Paulo: FCTH-USP, 1999. 289 p.

SILVA, G. B. L. Avaliação experimental da eficiência de superfícies permeáveis com vistas ao controle do escoamento superficial. 199f. 2006. Tese (Doutorado em Tecnologia Ambiental e Recursos Hídricos) - Universidade de Brasília, Brasília, 2006.

URBAN DRAINAGE AND FLOOD CONTROL DISTRICT. Urban storm drainage criteria manual. Denver: Urban Drainage and Flood Control District, 1991. 665 p. Vol. 3 - Best management practices.

WALESH, S. G. Urban surface water management. New York: John Wiley \& Sons, 1989. 599p. 